\title{
Upper Cretaceous dinoflagellate cyst stratigraphy, onshore West Greenland
}

\section{G E U S}

Report file no.

22322

Henrik Nøhr-Hansen
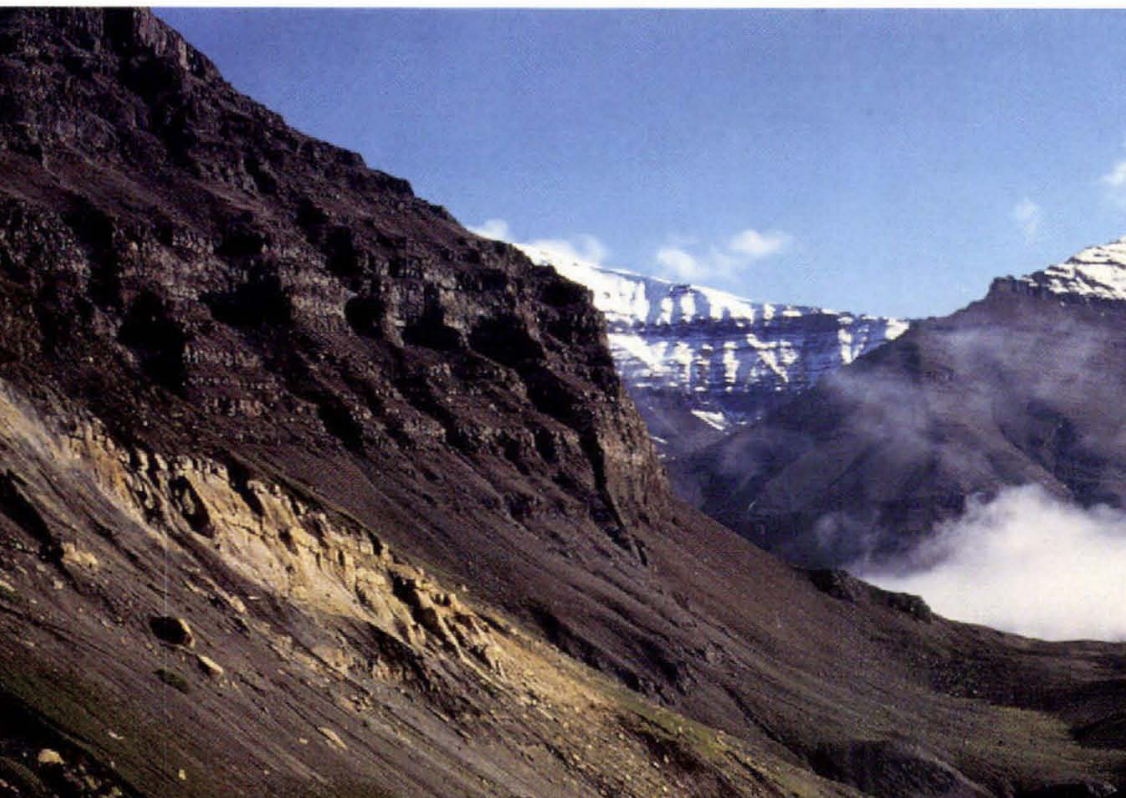

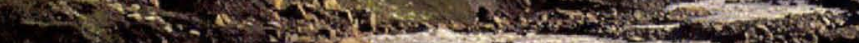

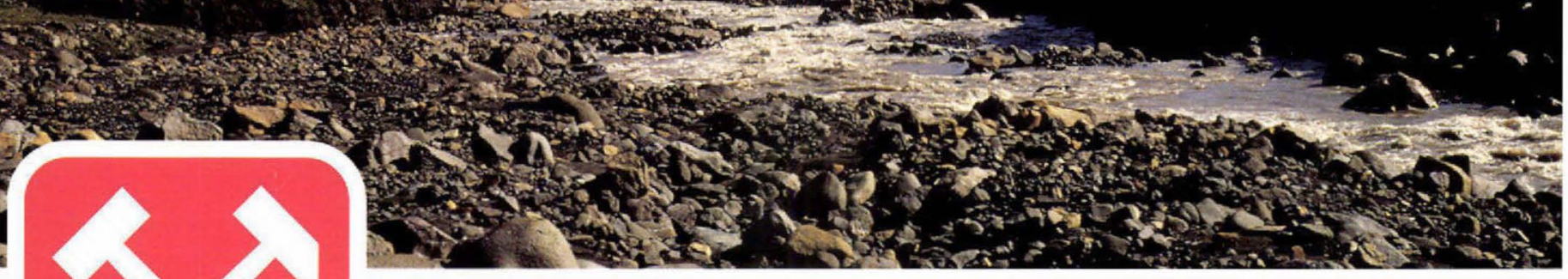

GRØNLANDS GEOLOGISKE UNDERSØGELSE 
GRØNLANDS GEOLOGISKE UNDERSØGELSE

Bulletin 170

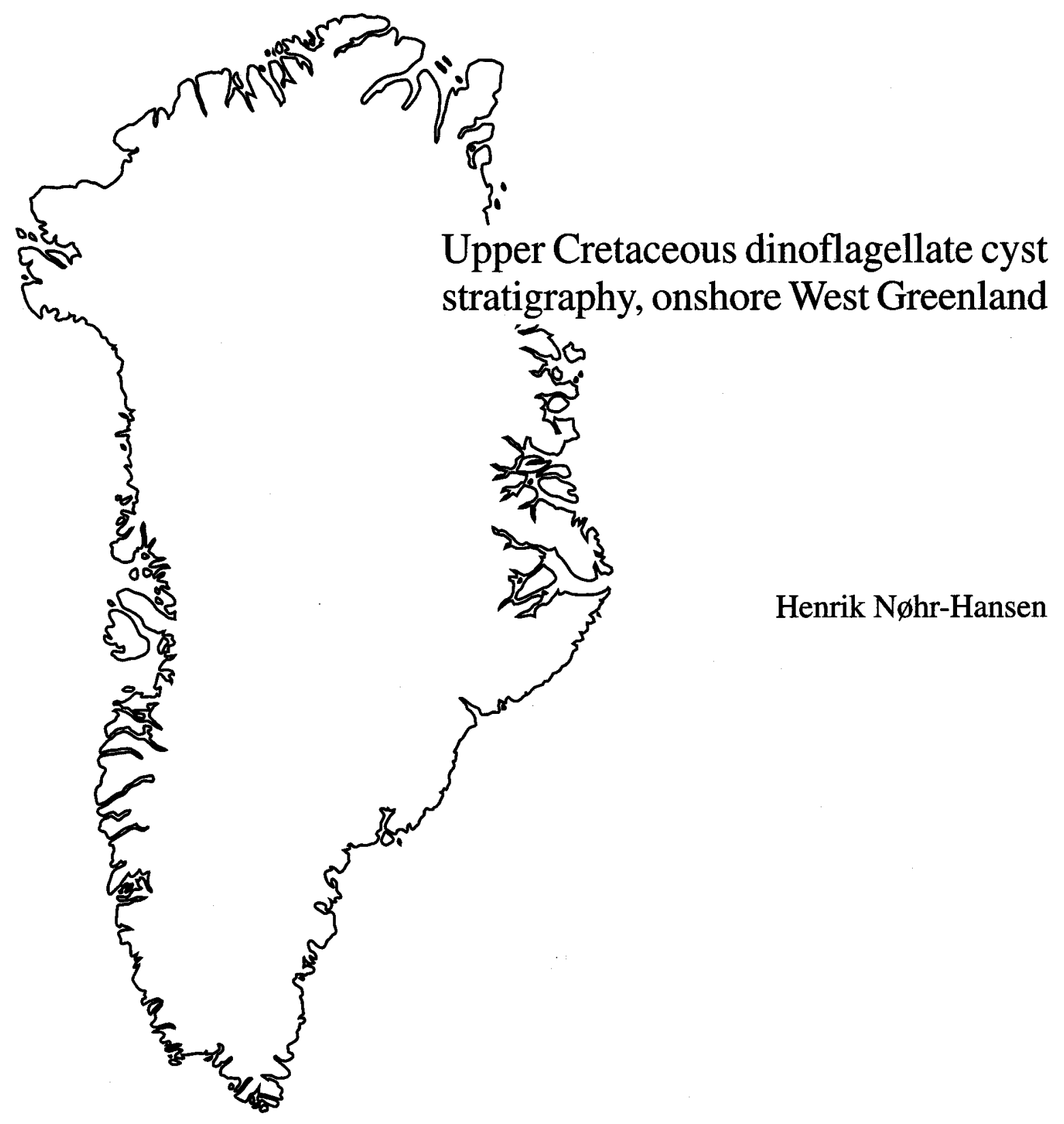


Nøhr-Hansen, H. 1996: Upper Cretaceous dinoflagellate cyst stratigraphy, onshore West Greenland. Bull. Grønlands geol. Unders. 170, 104 pp.

Stratigraphical ranges and geographical distribution of dinoflagellate cysts and selected pollen species are described based on the analysis of 250 samples from 29 surface and 12 subsurface sections of Late Cretaceous age from Svartenhuk Halvø and Nuussuaq peninsula, West Greenland. The sections make up an approximately $1500 \mathrm{~m}$ thick black mudstone succession, previously dated as late Turonian to Maastrichtian on the basis of scattered ammonite occurrences.

The dinoflagellate cysts and pollen indicate that the majority of the studied samples are Coniacian/Santonian to Maastrichtian. A few samples have been dated as early Paleocene. It is possible to divide the Upper Cretaceous strata into 10 intervals based on the palynomorph assemblages.

Diversity of dinoflagellate cysts is relatively high in the Coniacian to early Santonian deposits at Svartenhuk
Halvø, whereas it decreases in the younger Campanian and Maastrichtian strata of Nuussuaq. The Coniacian to early Santonian assemblages are dominated by the genera Chatangiella and Isabelidinium, which in several samples constitute 20 to 50 percent of the dinoflagellate content.

New finds of ammonites and study of the palynomorphs indicate that the Cretaceous-Tertiary boundary should be moved from the base of what was previously called the 'basal Danian conglomerate' at Annertuneq to approximately $118 \mathrm{~m}$ above the top of this conglomerate.

Systematic and stratigraphic notes are included on selected Arvalidinium, Cerodinium, Chatangiella and Isabelidinium species. Three new species, Alterbidinium? ulloriaq Chatangiella mcintyrei and Isabelidinium svartenhukense, are described.

Author's address:

Geological Survey of Denmark and Greenland,Thoravej 8, DK-2400 Copenhagen NV, Denmark.

\section{Cover picture}

Turritellakløft viewed from the west with Agatdalen in the background, central Nuussuaq, West Greenland. The Kangilia Formation represented in the lower part of the picture is a marine shale of late Santonian to Campanian/?Paleocene age. This is overlain by the Agatdal Formation represented by shallow marine sandstone of Paleocene age, covered by Paleocene volcanics of the Vaigat Formation. 


\section{Contents}

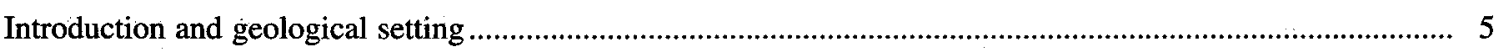

Previous palynological studies in the Upper Cretaceous of West Greenland ............................................ 5

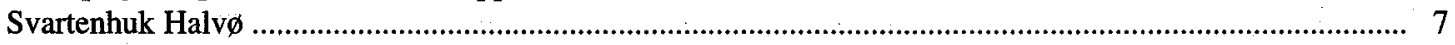

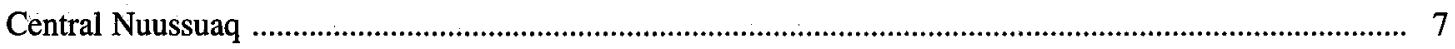

Northern Nuussuaq …......................................................................................................................... 9

Previous palynological studies in the upper Cretaceous elsewhere ............................................................. 9

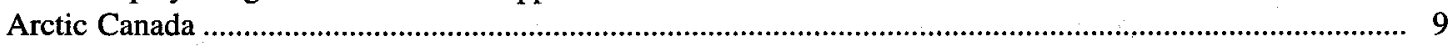

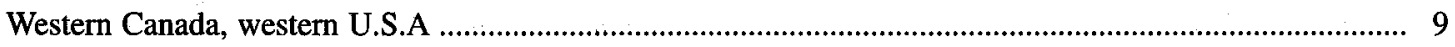

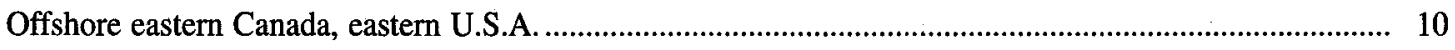

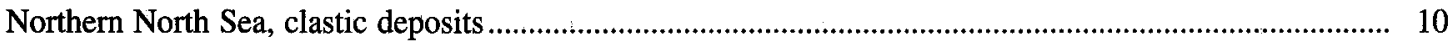

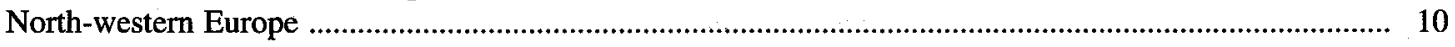

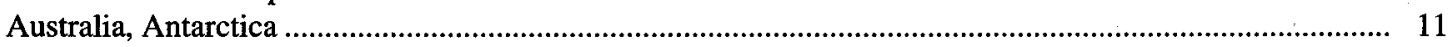

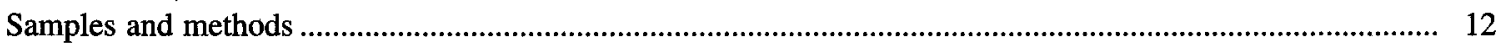

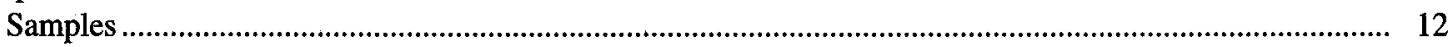

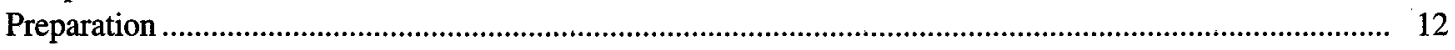

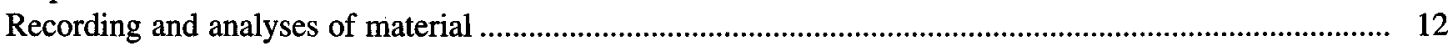

Composition and maturation of the organic material ............................................................................ 13

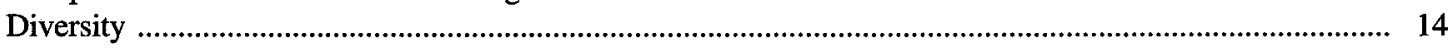

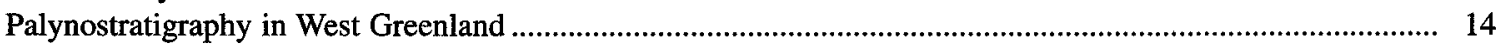

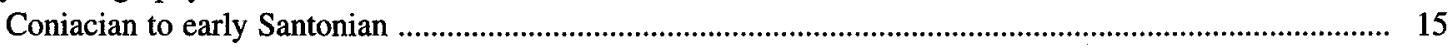

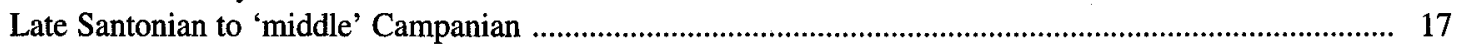

Late Campanian to late Maastrichtian ................................................................................................ 17

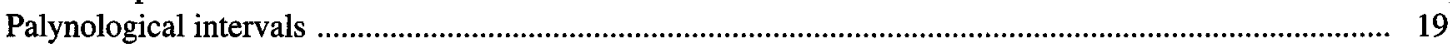

Chatangiella sp. cf. C. madura interval ...................................................................................... 19

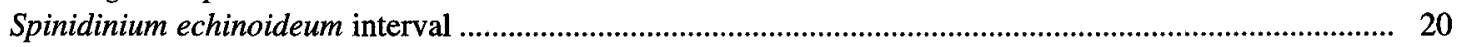

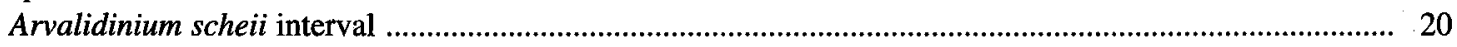

Laciniadinium arcticum interval ............................................................................................................. 21

Notes on the Laciniadinium arcticum/Heterosphaeridium difficile interval .............................................. 21

Heterosphaeridium difficile interval .................................................................................................. 21

Dinogymnium sp. cf. D. sibiricum interval .............................................................................................. 22

Notes on an almost barren interval above the Heterosphaeridium difficile/

Dinogymnium sp. cf. $D$. sibiricum interval ................................................................................... 22

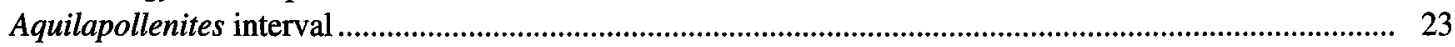

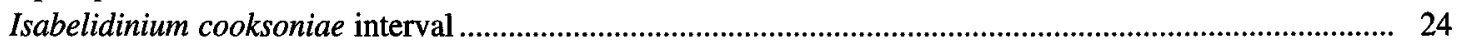

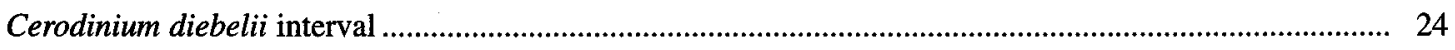

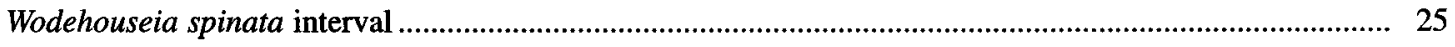

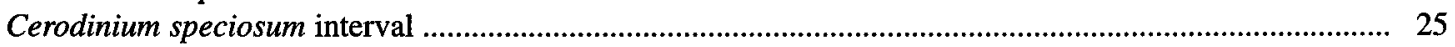

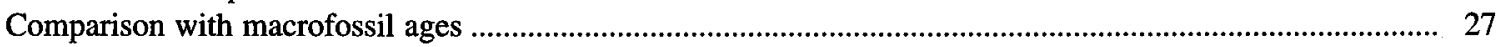

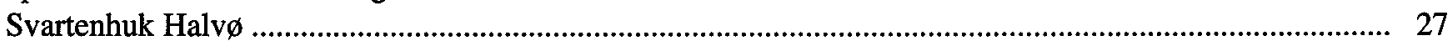

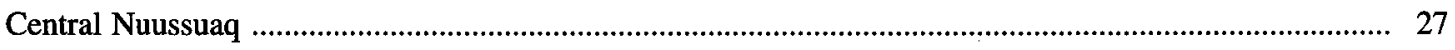

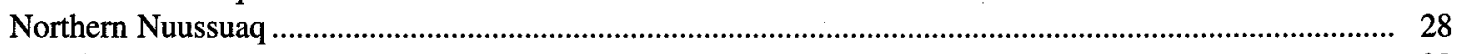

Systematic and stratigraphic notes on selected dinoflagellate cysts ...................................................... 28

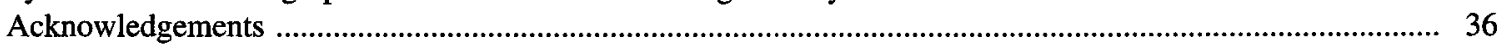

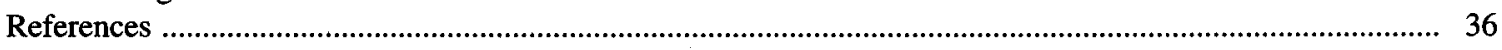

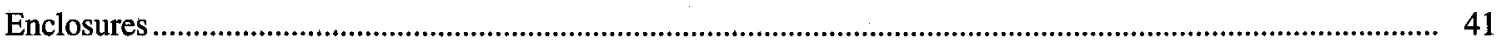

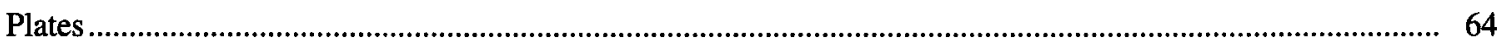

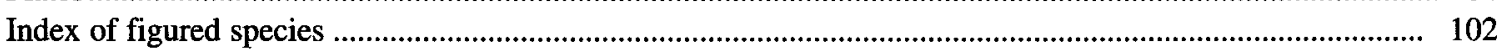




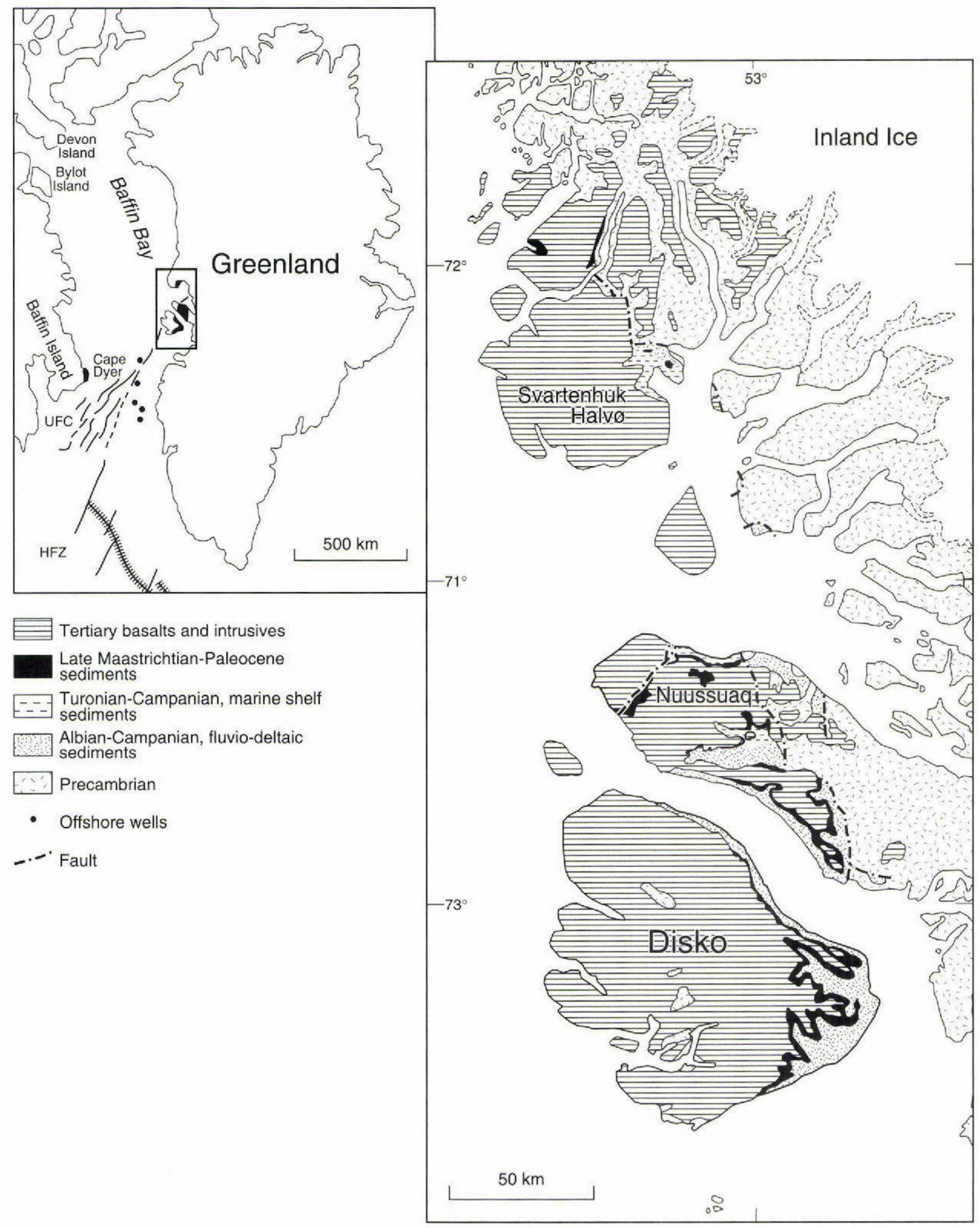

Fig. 1. Geological map of central West Greenland, showing the location of the Cretaceous outcrops in the studied area. Based on maps from the Geological Survey of Greenland. HFZ=Hudson Land Fracture Zone, UFC= Ungava Fault Complex. 


\section{Introduction and geological setting}

This study is part of the Geological Survey of Greenland (GGU) project 'Sequence stratigraphic analysis of the Cretaceous sediments in West Greenland', and aims to establish a palynostratigraphy for the Disko-Nuussuaq-Svartenhuk Halvø area in West Greenland (Christiansen et al., 1992; Christiansen, 1993; Nøhr-Hansen, 1993, 1994a, b, c).

The West Greenland continental margin is a rifted margin developed during the opening of the Labrador Sea in late Mesozoic - early Cenozoic time (Fig. 1). A number of rift basins developed along the continental break-up zone which stretches from the Labrador Sea to northern Baffin Bay (Rolle, 1985; Chalmers, 1991; Chalmers \& Pulvertaft, 1993; Chalmers et al., 1993). In this region onshore exposures of Mesozoic - Lower Tertiary sediments occur only at Cape Dyer on Baffin Island, Canada (Burden \& Langille, 1990; 1991) and in central West Greenland on a number of islands and peninsulas between $69^{\circ}$ and $72^{\circ}$ (Rosenkrantz, 1970). Farther north in Canada Cretaceous and Tertiary sediments of marine origin are exposed on Bylot and Devon Islands (Ioannides, 1986; Benham \& Burden, 1990). While the deposits on Baffin Island have a limited distribution and consist mainly of fluviatile sediment (Burden \& Langille, 1990), the deposits in West Greenland cover a larger area and include both marine and terrestrial strata (Henderson et al., 1976; Pedersen \& Pulvertaft, 1992; Dam \& Sønderholm, 1994). Studies of the deposits from West Greenland are therefore essential for a detailed interpretation of not only onshore but also offshore geology in the region.

In West Greenland the onshore basin of the rifted continental margin, which developed in late Mesozoic
- early Cenozoic time, has a preserved sedimentary succession more than $2.5 \mathrm{~km}$ thick (Henderson et al., 1981; Pulvertaft, 1987). The sediments, which range from early Cretaceous (Albian) to early Tertiary (Paleocene), are overlain by volcanic rocks of Paleocene age (Pedersen, 1985; Piasecki et al., 1992; Larsen et al., 1992). The Cretaceous to Tertiary outcrops are bounded to the east by Precambrian basement rocks against which the Cretaceous sediments have a faulted contact (Rosenkrantz \& Pulvertaft, 1969; Pedersen \& Pulvertaft, 1992). Towards the west, south and north the basin passes into offshore areas and the margins, however connected, are still not mapped.

Shelf mudstones of Coniacian to Santonian age are exposed on Svartenhuk Halvø. The Campanian shelf mudstones on the north coast of Nuussuaq are unconformably overlain by Maastrichtian shelf deposits (Dam \& Sønderholm, 1994).

Biostratigraphic correlation of the sediments in the region is difficult due to the interdigitation of Cretaceous fluviatile, deltaic and brackish to fully marine deposits which have been dated using different fossil groups (Birkelund, 1965; Schiener, 1975; Pulvertaft, 1979, 1987; Pedersen \& Pulvertaft, 1992). The Upper Cretaceous succession yields no microplankton (Hansen, 1970). The Maastrichtian to Lower Paleocene succession has been divided into two sequence stratigraphic units by Dam \& Sønderholm (1994).

Field work on the marine succession in the summers of 1990 to 1992 was concentrated on detailed sedimentological studies, sampling for palynological and organic geochemical studies, and mapping and structural analysis (Christiansen et al., 1992).

\section{Previous palynological studies in the Upper Cretaceous of West Greenland}

Previous studies of Upper Cretaceous dinoflagellate cysts from West Greenland are by Croxton $(1976,1978 \mathrm{a}, \mathrm{b}$, 1980), Ehman et al. (1976), Lentin \& Williams (1980). Lentin \& Williams mentioned $(1980$, p. 20$)$ that the Campanian assemblage from West Greenland contains elements of both the offshore eastern Canadian assemblages (the Williams suite) and the Mackenzie Delta assemblages from arctic Canada (the McIntyre suite) described by McIntyre (1974, 1975). The present study confirms this observation. Paleocene dinoflagellate cyst assemblages from West Greenland have been described by Hansen (1980) and Piasecki et al. (1992). 


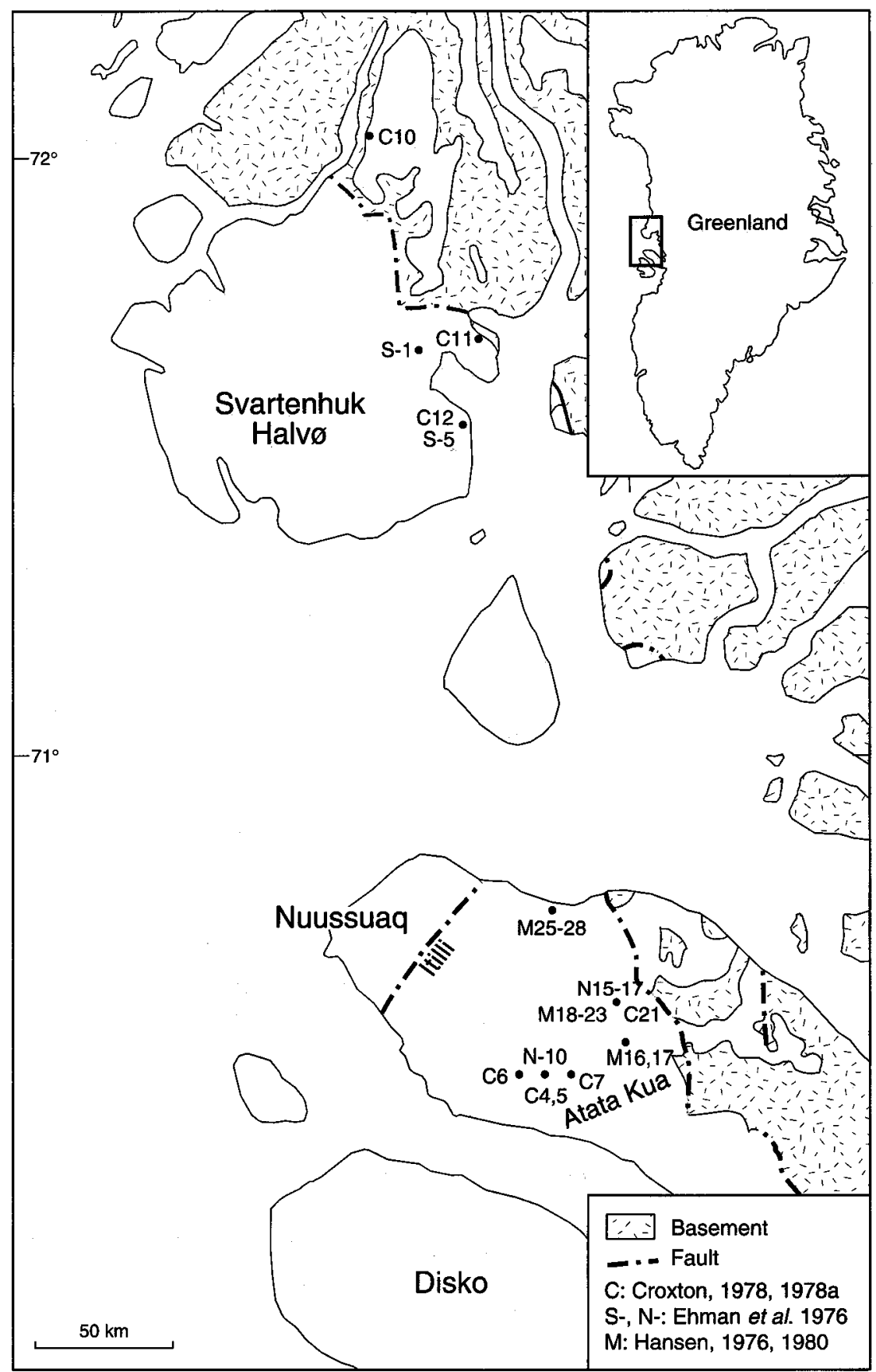

Fig. 2. Map showing location of previously measured and palynologically analysed Upper Cretaceous sections on Svartenhuk Halvø and Nuussuaq.

\section{Svartenhuk Halvø}

Croxton (1978a) briefly described the palynomorph content from three localities at Svartenhuk Halvø and Itsaku (C10, C11, C12; Fig. 2). Pollen from the C10 locality was determined as Paleocene, while pollen and dinoflagellate cysts suggested a Coniacian to Campanian age for C12. Croxton (1978a, p. 65) mentioned that the thermally altered palynomorphs from the Itsaku section C11 caused problems; however, she dated the lower part of the section as late Albian - early Cenomanian, and noted that pollen from the top of the section may indicate a Paleocene age.

Pulvertaft (1987, table 1) noted that the Cenomanian age for localities S5 and S1 in the Umiivik (Umîvik) 
Fig. 3. Location of the outcrop and subsurface sections on Svartenhuk Halvø that yielded dinoflagellate cysts.

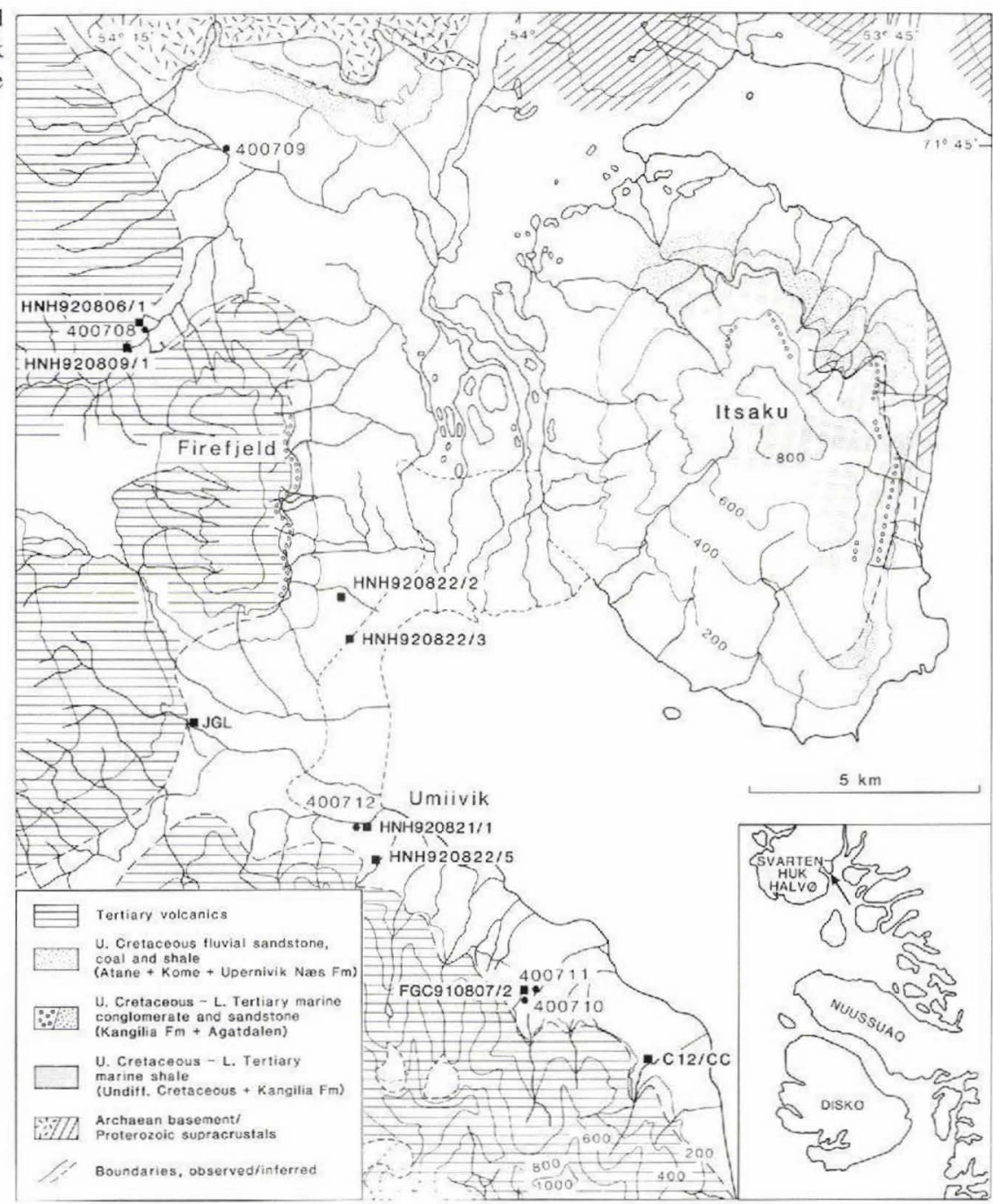

(Fig. 3) area given by Ehman et al. (1976), are not consistent between text and logs.

Hansen (1980, p. 92) recorded early Paleocene dinoflagellate cysts from an unspecified locality in the Svartenhuk area.

Nøhr-Hansen (1994a) described the palynomorph content from 9 surface and 5 subsurface sections on Svartenhuk Halvø (Fig. 3), and dated the approximately $300 \mathrm{~m}$ marine succession as Coniacian/early Santonian to ?early Campanian (Fig. 9).

\section{Central Nuussuaq}

Croxton (1978a, b) briefly described the palynomorph assemblages from five localities in central Nuussuaq (C4C7, C21, M19, M22; Fig. 2). The palynomorphs from the localities at Qilakitsoq (C4), Qaatunnat Ilorliit (C5), Ilugisssoq (C6) and Nallurarissat (C7) indicate a late Ceno- manian to early Campanian age. A possible reworked Maastrichtian assemblage is recorded from the top of section $\mathrm{C} 5$, and dinoflagellate cysts from the topmost shale at $\mathrm{C} 6$ indicate a possible 'middle' Paleocene age (Croxton, 1978a). Sections C21 and M19 represent the 'Oyster-ammonite conglomerate' from Agatdalen; according to Croxton (1978b) palynomorphs from these section may indicate reworked Maastrichtian floras. Eight sections from central Nuussuaq (M16-M23; Fig. 2) were sampled by Hansen (1976); data on the palynological content from the two sections M16 and M17 from Tunoqqu have not been published. A few dinoflagellate cysts, probably indicating a late Campanian age, were recorded by Croxton (1978a) from Scaphitesnæesen (M22).

Hansen (1980) described the Paleocene dinoflagellate cysts from the Sonja section (M18), Turritellakløft section (M20), Qaarsutjægerdal section (M21) and Ättestupet section (M23). According to Hansen (1980) 


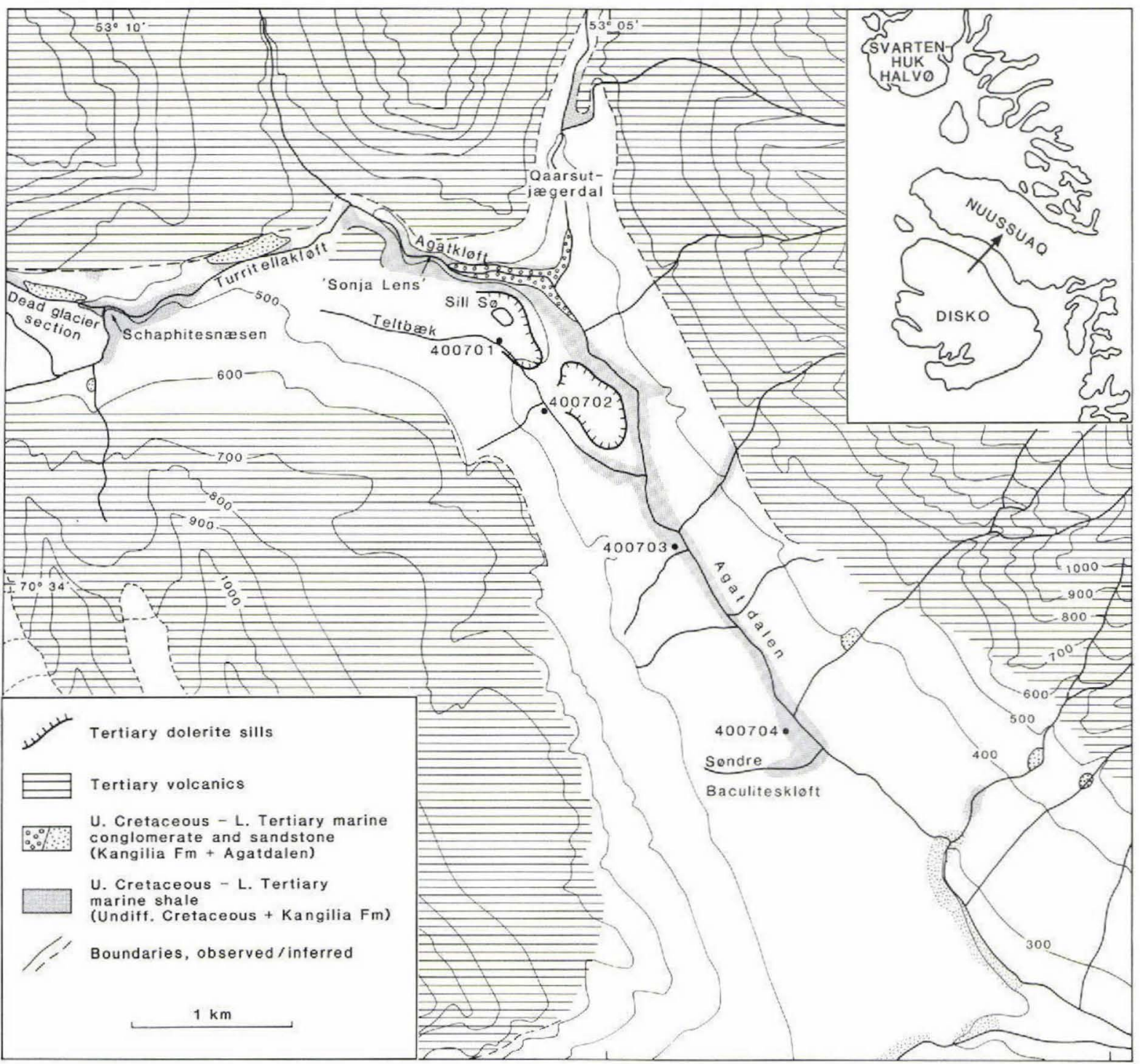

Fig. 4. Location of the outcrop and subsurface sections in the Agatdalen area that yielded dinoflagellate cysts.

the 'middle' Campanian to early Maastrichtian species Isabelidinium microarmum is recorded as reworked specimens in the sections M18-M21.

Ehman et al. (1976) studied the four sections (Fig. 2) Qilakitsoq (N10), Turritellakløft (N15), Qaarsutjægerdal (N16) and Nassaat (N17) in central Nuussuaq. The ages given by Ehman et al. (1976) are middle Cenomanian and early Danian for N10, Campanian or Maastrichtian to Paleocene for N15, Paleocene for N16 and N17. It should be noted that the ages given in the text by Ehman et al. (1976) are not always consistent with the ages given in their logs (Pulvertaft, 1987, table 1).
Nøhr-Hansen (1994b) described the palynomorph assemblages from 15 surface and 4 subsurface sections around Agatdalan and from the valleys Kangersooq and Aaffarsuaq south of Agatdalen (Figs 4, 5), and dated the $1100 \mathrm{~m}$ thick marine succession as late Santonian to 'middle' Campanian (Fig. 10). One sample is dated as Paleocene.

D. J. McIntyre (personal communication, 1995) described the Upper Cretaceous spore and pollen assemblages from the Ataata Kuua section in south-west Nuussuaq (Fig. 2). 


\section{Northern Nuussuaq}

Croxton (1978a, b, 1980) briefly described palynomorph assemblages from three localities between Niaqornat and Ikorfat on the north coast of Nuussuaq (M25, M27-28; Fig. 2). The palynomorphs from these three localities in the Kangilia and Annertuneq area indicate a late Campanian to Maastrichtian age.

Hansen (1980) described the Paleocene dinoflagellate cysts and proposed a zonation for the mudstone deposited above the so-called 'basal Danian conglomerate' at the Kangilia/Annertuneq section (M25; Fig. 2, Enclosure 38).

Piasecki et al. (1992) described 'mid'-Paleocene dinoflagellate cyst assemblages from sediments interbedded in the Tertiary volcanic rocks on Disko and Nuussuaq and dated the sediments as NP 4 to NP 8.
Nøhr-Hansen (1993) described a low diversity dinoflagellate assemblage of late Maastrichtian? to early Paleocene age from the uppermost part of the more than two kilometre thick turbidite succession exposed immediately below the Tertiary pillow breccia on the south-east side of the Itilli valley in Nuussuaq (Fig. 2), and compared the results with preliminary palynological studies of the Kangilia section (Figs 6, 7). Nøhr-Hansen (1994c) described the palynomorph assemblages from 5 surface and 3 subsurface sections between Niaqornat and Ikorfat on the north coast of Nuussuaq (Figs 6,7). The sections make up an approximately $500 \mathrm{~m}$ thick black mudstone succession. The dinoflagellate cysts and pollen date the majority of the samples as late Campanian and Maastrichtian. A few samples have been dated as Coniacian - late Santonian and early Paleocene.

\section{Previous palynological studies in the Upper Cretaceous elsewhere}

\section{Arctic Canada}

Santonian to Maastrichtian Upper Cretaceous dinoflagellate cysts have been described from arctic Canada by Manum (1963), Manum \& Cookson (1964), Felix \& Burbridge (1976), McIntyre (1974, 1975), Doerenkamp et al. (1976), Ioannides \& McIntyre (1980), Ioannides (1986), Núñez-Betelu \& Hills (1992), Núñez-Betelu et al. (1994) and Núñez-Betelu (1994). Ioannides (1986) studied the dinoflagellate cyst assemblages from the Santonian to Maastrichtian part of the Kanguk Formation and the Lower Paleocene Eureka Sound Formation on Bylot and Devon Islands. The dinoflagellate cyst assemblages described by Ioannides (1986) are very similar to these from West Greenland. Unfortunately, Ionnanides' stratigraphy is not very detailed due to poor outcrop and absence of macrofossils.

Núñez-Betelu (1994) described the source-rock potential and palynomorphs, and recorded one late Coniacian ammonite from the Turonian to Campanian Kanguk Formation in the area around Eureka Sound (situated between Axel Heiberg Island and Ellesmere Island), arctic Canada. Núñez-Betelu (1994) described four palynozones of which the three youngest partly correlate with the assemblages described from West Greenland.

\section{Western Canada, western U.S.A.}

Upper Cretaceous dinoflagellate cyst assemblages from western Canada and western U.S.A. have been described by Stanley (1965), Wall \& Singh (1975), Harland (1973, 1977), Sweet \& McIntyre (1988), Stone (1973), Harker et al. (1990) and Kurita \& McIntyre (1994). Nichols \& Sweet (1993) described the biostratigraphy of the Upper Cretaceous non-marine palynofloras in a north-south transect of the Western Interior Basin. The stratigraphical ranges given for the genera Aquilapollenites and Wodehouseia by Nichols \& Sweet (1993) are very important for the dating the Upper Cretaceous strata of northern Nuussuaq.

\section{Offshore eastern Canada, eastern U.S.A.}

Burden \& Langille (1991) described the palynology of the Cretaceous and Tertiary strata at Cape Dyer, eastern Baffin Island. These strata, which contain Aptian to Albian and Paleocene to Eocene terrestrial palynomorphs, are the onshore Cretaceous to Tertiary deposits closest to West Greenland.

The Upper Cretaceous dinoflagellate cyst assemblages from offshore eastern Canada were described by Barss $e t$ al. (1979), Bujak \& Williams (1978), Williams (1975), Williams \& Brideaux (1975), Williams \& Bujak (1977a, 1977b), Williams et al. (1974) and Williams et al. (1990).

The stratigraphical distribution of Mesozoic and Cenozoic dinoflagellate cysts has been described by Williams \& Bujak (1985) for the world and by Williams et al. (1993) for the northern hemisphere.

Upper Cretaceous to Paleocene dinoflagellate cyst assemblages from eastern U.S.A. were described by Benson (1976), May (1980), Tocher (1987), Moshkovitz \& Habib (1993), Aurisano \& Habib (1977) who established 


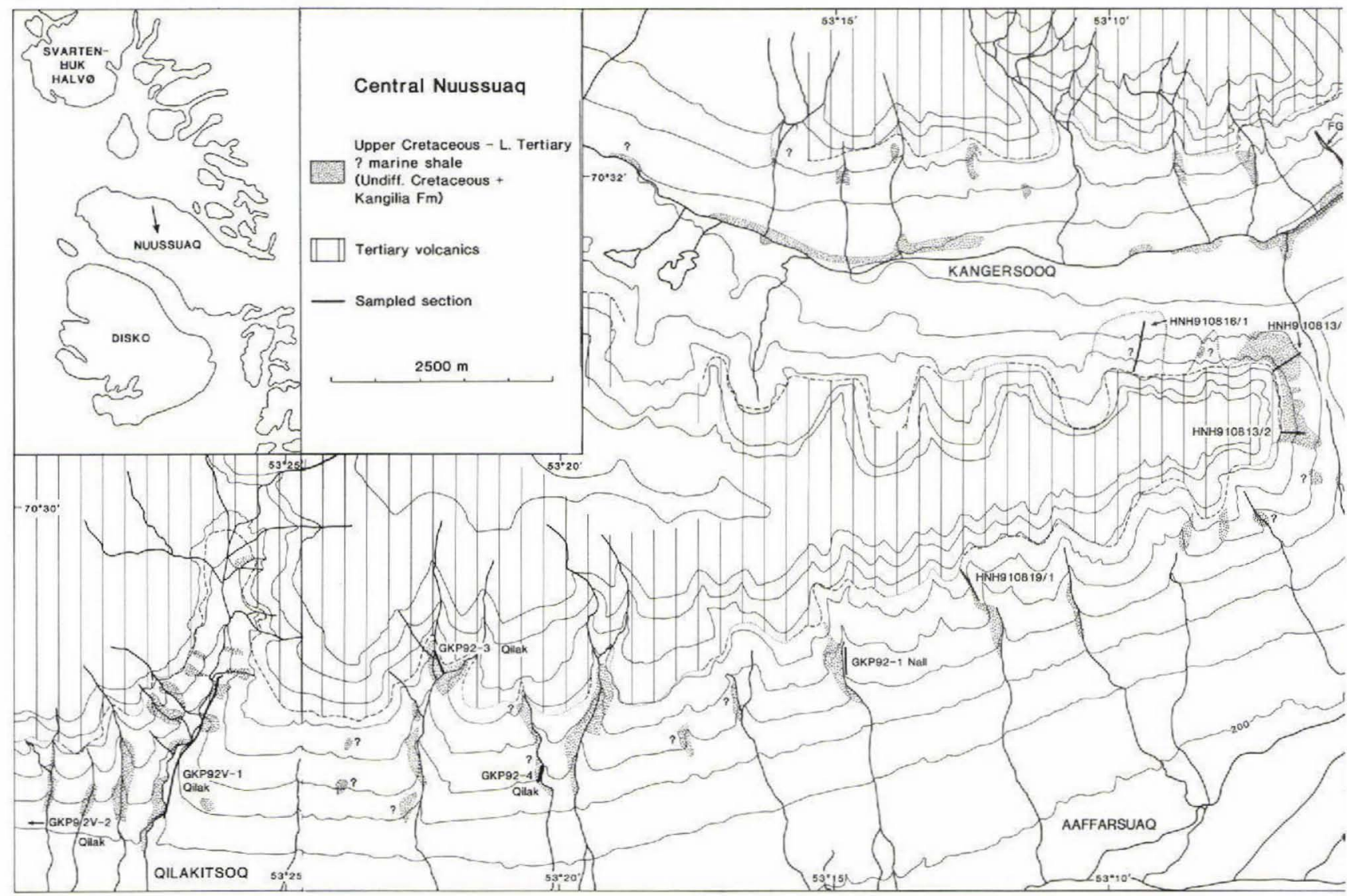

Fig. 5. Location of the outcrop and subsurface sections south of the Agatdalen area that yielded dinoflagellate cysts.

a Campanian to lowermost Tertiary dinoflagellate cyst zonation, and by Aurisano (1989) who proposed a Cenomanian to Maastrichtian dinoflagellate cyst zonation for the Atlantic Coastal Plain of New Jersey and Delaware.

\section{Northern North Sea, clastic deposits}

According to Costa \& Davey (1992, pp. 105-106) dinoflagellate cyst information has not been published from this region, apart from Costa (1985). However observations by Lucy I. Costa (reported in Costa \& Davey, pp. 105-106) indicate assemblage affinities with the Upper Cretaceous arctic assemblages described by Vozzhennikova (1967) from Siberia, Manum \& Cookson (1964) and Doerenkamp et al. (1976) from arctic Canada, and McIntyre (1974) from the District of Mackenzie, Canada.

\section{North-western Europe}

The stratigraphical distribution of Upper Cretaceous dinoflagellate cysts in North-West Europe has been com- piled by Foucher (1979) and Costa \& Davey (1992). Clarke \& Verdier (1967) described the Cenomanian to Campanian on the Isle of Wight and made the first and only attempt to establish a dinoflagellate zonation for the British Upper Cretaceous. The dinoflagellate cyst assemblage from the Turonian type area around Saumur in France has been described by Foucher (1982). Tocher \& Jarvis (1987) described Turonian dinoflagellate cysts from Devon, England. Jarvis et al. $(1987,1988)$ described the Albian to Turonian stratigraphy and anoxic events in the Cenomanian-Turonian.

Foucher (1971a,b) and Robaszynski et al. (1980) described dinoflagellate cyst assemblages of Coniacian age from France. Schiøler (1992) described a diverse dinoflagellate cyst assemblage from the island of Bornholm, Denmark. Westin (1992) established a dinoflagellate cyst stratigraphy from the Albian to Santonian in southern Sweden. The diverse assemblages described from Bornholm (Schiøler, 1992) and Sweden (Westin, 1992) are dominated by North Sea and North-West European limestone facies species; however the abundance of the northern North Sea genus Chatangiella, especially in southern Sweden, is remarkable. Yun (1981) described a 


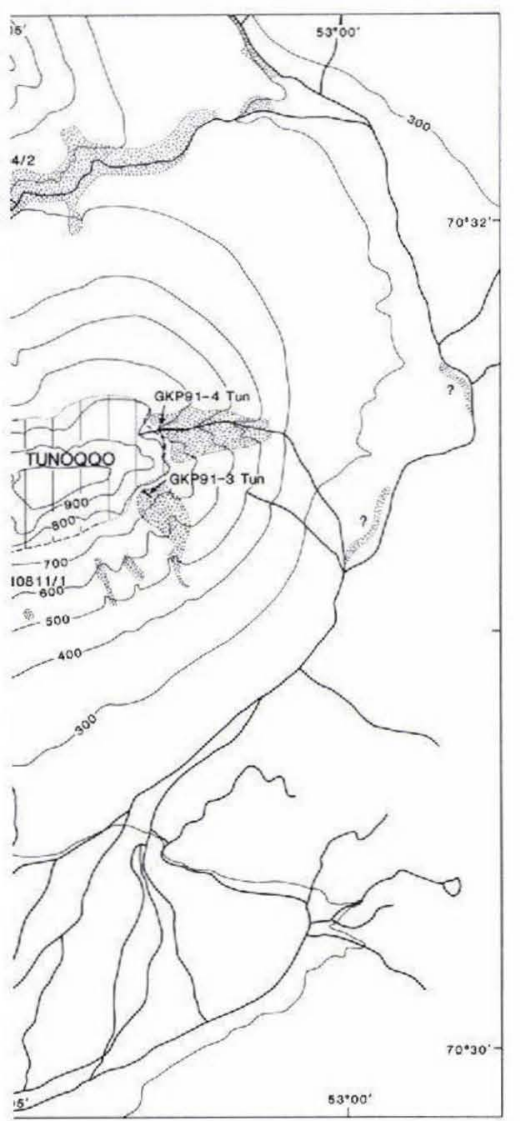

Lower Santonian dinoflagellate cyst assemblage from north-west Germany.

Foucher (1983) and Robaszynski et al. (1983) described the palynology of the Campanian to Maastrichtian in Belgium and the Netherlands. Hart et al. (1987) listed dinoflagellate cysts together with other microfossils from key Upper Cretaceous sections on the Isle of Wight. Prössl (1990) proposed a dinoflagellate cyst zonation for the late Hauterivian to the late Turonian in Germany. Kirsch (1991) described the dinoflagellate cyst content and proposed a zonation for the Turonian to late Maastrichtian from the Oberbayern in southern Germany. Marheinecke (1992) described the dinoflagellate cyst content and proposed a zonation for the Maastrichtian from Niedersachsen in northern Germany. Schiøler \& Wilson (1993) proposed a dinoflagellate cyst zonation for the Dan Field in the Danish part of the North Sea.

\section{Australia, Antarctica}

There are numerous papers describing Cretaceous dinoflagellate cysts from Australia. Helby et al. (1987) established a palynological zonation covering the entire Mesozoic of Australia.

Askin (1988) described the Campanian to Eocene palynological succession of Seymour Island and adjacent islands, Antarctica.

Mohr \& Gee (1992) and Mao \& Mohr (1992) described the Cenomanian to Maastrichtian dinoflagellate cyst assemblages from the ODP leg 120 in the southern Indian Ocean.

The interesting point about the Upper Cretaceous palynomorphs recorded from Australia and around Antarctica is that they are very similar at generic level to the material recorded from West Greenland, whereas there are small but distinguishable differences between superficially similar species from the two regions, which makes direct correlation difficult.

\section{Samples and methods}

\section{Samples}

This study covers samples from Svartenhuk Halvø and Nuussuaq obtained from 29 surface localities and 12 slim cores from shallow slim core holes drilled by GGU's helicopter-transportable drilling equipment in 1992 (Figs $3-7)$. The sections are 20 to 470 metres thick and represent an approximately $1500 \mathrm{~m}$ thick mudstone succession.

\section{Preparation}

Palynological preparation and studies were carried out at GGU. Palynomorphs were extracted from $20 \mathrm{~g}$ of sample by modified standard preparation techniques. The bulk of the minerals were dissolved by hydrochloric and hydrofluoric acids. A first slide was made after this treatment. A second slide was made of the organic residue after sieving using a 20 micron nylon mesh. A third slide was made after oxidation ( 3 to 10 minutes) with fuming nitric acid, followed by washing with a weak potassium 


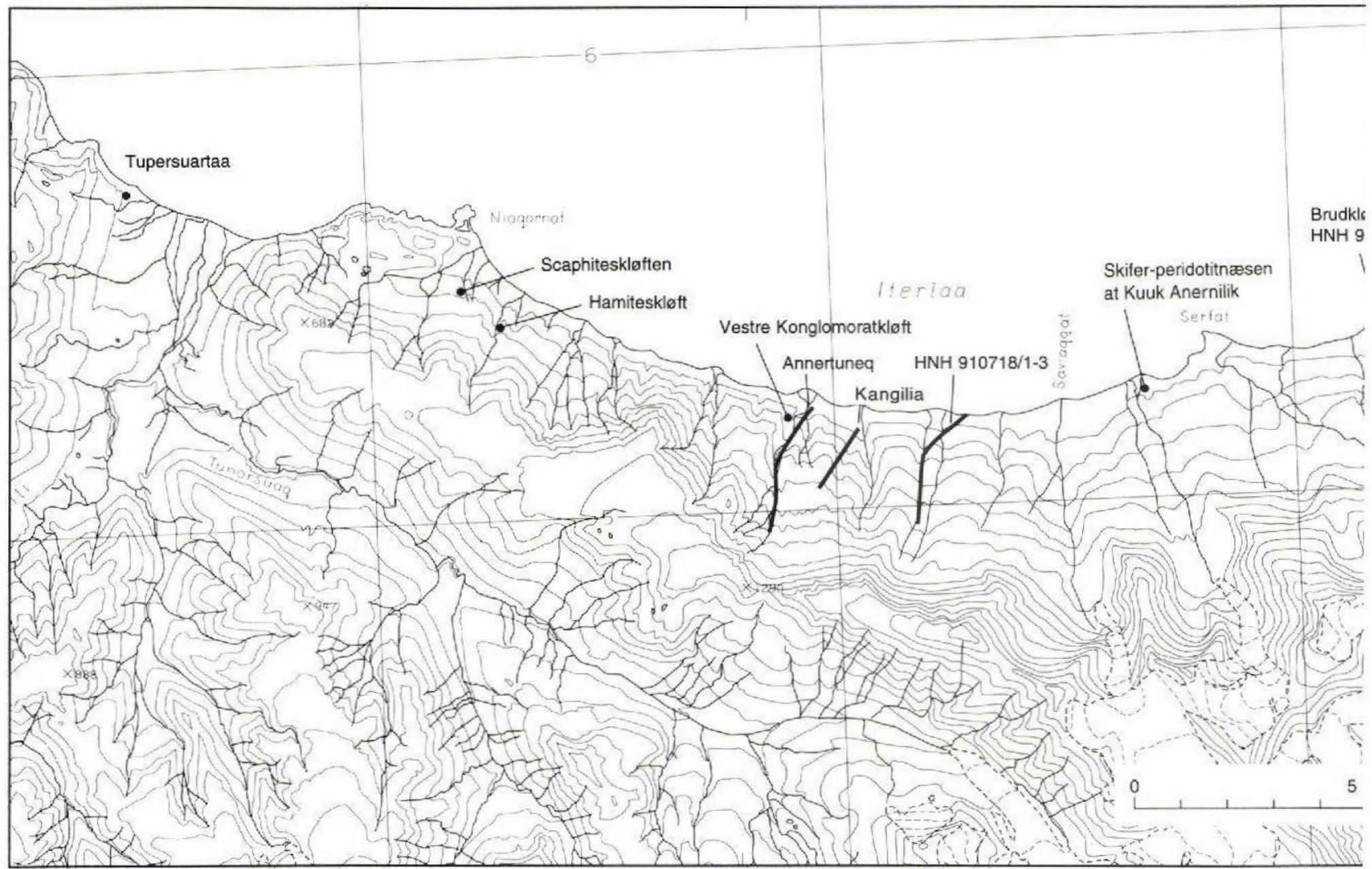

Fig. 6. Location of the outcrop sections on the north coast of Nuussuaq that yielded palynomorphs, and Birkelund's (1965) ammonite localities.

hydroxide solution. The oxidation was carried out in order to clean the sample of minor amorphous kerogen particles and pyrite. Finally, palynomorphs were separated from coal particles and woody material in most samples using the separation method described by Hansen \& Gudmundsson (1978).

After each of the steps mentioned above the organic residues were mounted in a permanent medium (Eukitt $\mathrm{R}$; produced by $\mathrm{O}$. Kindler, Germany).

\section{Recording of material and analyses}

The palynological slides were studied with transmitted light using a Leitz Dialux 22 microscope (512 742/ 057691). All the coordinates in the plate captions refer to this microscope. England finder index corners: Z $754=$ $74.6-92.3$; Z $13=1.9-9220 ;$ A $11=1.9-116.7$; A 652 $=64.6-116.6$, centre: $\mathrm{O} 38=38.1-103.3$.

The illustrated dinoflagellate cysts are marked with GGU number (sample number), slide number, microscope coordinates, laser-video-record number (LVR) and database number (MicroImage; MI) for later identification. The illustrated dinoflagellate cysts are also marked with MGUH numbers and are kept in the type collection of the Geological Museum of the University of Copenhagen. The additional palynological preparations from the West Greenland samples are housed at the Geological Survey of Greenland (Copenhagen) where they are accessible for examination.

Dinoflagellate cysts, acritarchs and selected stratigraphically important pollen species were recorded from the sieved, oxidised or gravitation-separated slides. Counting of specimens was only done on the material from the north coast of Nuussuaq, where approximately $100 \mathrm{spec}-$ imens were counted when possible.

Reworked species are recorded by their different state of preservation and by their ?Jurassic or Lower Cretaceous origin. Reworked species constitute a minor part of the examined material, except from the lowermost Paleocene sample from the Annertuneq section on the north coast of Nuussuaq, where brown specimens of Cribroperidinium? perforans constitute $30 \%$ of the assemblage. 


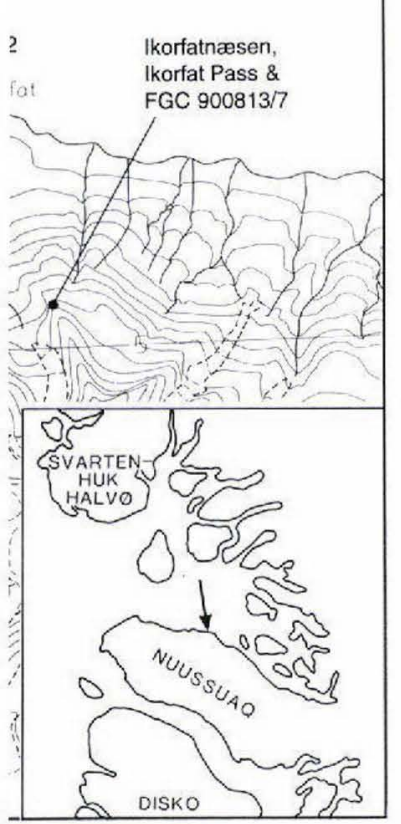

Fig. 7. Location of the outcrop and subsurface sections in the Annertuneq area that yielded palynomorph:

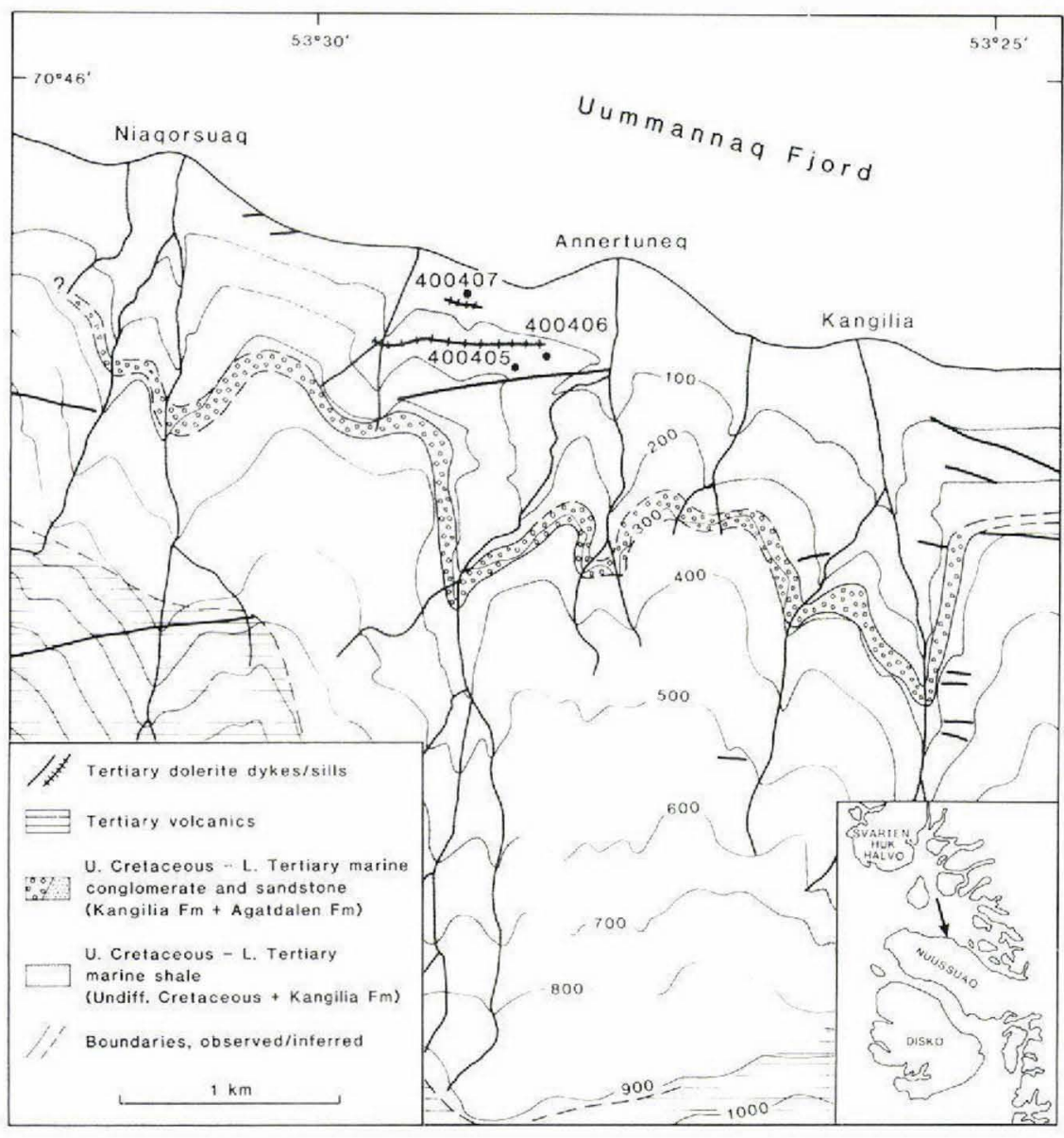

\section{Composition of the organic material and maturation}

The organic material is dominated by terrestrially derived black to brownish woody material and cuticles, whereas amorphous organic material, dinoflagellate cysts, spores and pollen constitute only a minor part, 137 dinoflagellate cysts, acritarchs and selected stratigraphically important pollen species were recorded.

A TAI (Thermal Alteration Index) evaluation was carried out on the unoxidised sieved slide. The study revealed TAI values between -2 and 3 , which indicate that the organic material is thermally immature to mature with respect to oil generation. The TAI values agree with the chemical analyses of the organic material which yielded $\mathrm{T}_{\max }$ values between 404 and $456^{\circ} \mathrm{C}$.

\section{Diversity}

The diversity of dinoflagellate cyst species as measured by the number of recorded species per sample varies from 1 to 32 (Enclosure 39). The highest diversity (19 to 32 ) occurs in the lowermost $200 \mathrm{~m}$ of strata of Coniacian to early Santonian age, recorded from Svartenhuk Halvø. The two diversity maxima $(30,31)$ both occur within the range of Arvalidinium scheii, whereas the diversity decreases above the last occurrence of $A$. scheii (Enclosure 39 ). The stratigraphically younger sections studied from Nuussuaq all have a lower diversity $(1-20)$. The species diversity of the upper Santonian to middle Campanian deposits in central Nuussuaq is very low (1-8), except for a level in the lower middle part and in the upper part of the Aquilapollenites interval, where the species diversity increases to 13 and 14 , respectively. The species diversity of the upper Campanian deposits at the north coast of Nuussuaq is also low (1-9), whereas it increases to 19 at the level dated as late Campanian or early Maastrichtian (just below the basal Danian conglomerate, Enclosure 39). Odontochitina species have their last occurrence at the same level. The diversity of the Maastrichtian deposits on the north coast of Nuussuaq, above the basal Danian conglomerate, is moderate (5-15). 


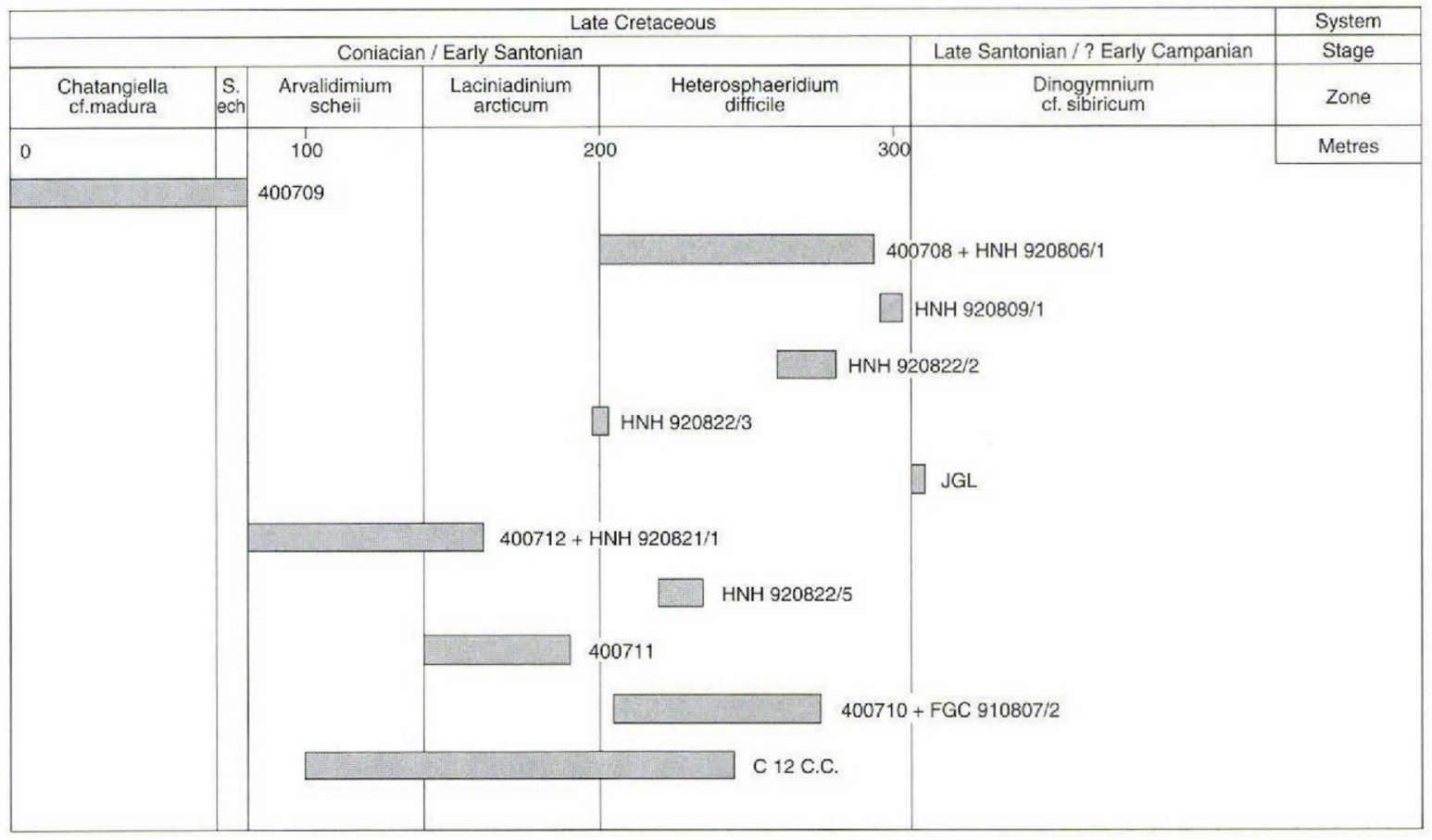

Fig. 8. Stratigraphical correlation of the sections on Svartenhuk Halvø that yielded dinoflagellate cysts.

\section{Palynostratigraphy in West Greenland}

The dinoflagellate cyst and pollen stratigraphy that is here proposed for the marine Upper Cretaceous on Svartenhuk Halvø and Nuussuaq is based principally on a detailed study of material from 29 surface sections and 12 slim cores from shallow core holes.

Additional spot samples from ten other surface sections have been studied in order to confirm that the sections include the entire Upper Cretaceous mudstone sequence exposed between Niaqornat and Ikorfat on the northern coast of Nuussuaq (Figs 6,7).

Due to the very sparse macrofossil content and the rather homogeneous lithology, the stratigraphical correlation of the geographically widely spread sections is based solely on the first and the last occurrences and acme of stratigraphically important dinoflagellate cysts and pollen.

\section{Coniacian to early Santonian}

Dinoflagellate cysts of Coniacian to early Santonian ages have been recorded in all (Enclosures 2-6, 8-12) but one (JGL, Enclosure 7) of the sections studied on Svartenhuk Halvø (Figs 3,8), in four sections in central Nuussuaq (FGC 900804/2 Agat., GKP 921 Nall., GKP 92 V 1 Qilak., \& GKP 92 V 2 Qilak. Fig. 5; Enclosure 26, Enclosure 28, Enclosures 31 and 32) and one section
HNH 920824/2 (Enclosure 37) at Ikorfat on the north coast of Nuussuaq (Fig. 6).

The dinoflagellate cyst assemblages from the Coniacian to early Santonian are characterised by a large number of specimens of Chatangiella. According to the literature the genus Chatangiella ranges from the late Cenomanian to the late Maastrichtian (Costa \& Davey, 1992, and many others). The genus Chatangiella is abundant and is often dominant in late Cretaceous assemblages in the western interior of the U.S.A., western Canada, arctic Canada and the northern North Sea. Chatangiella is also very abundant in the southern hemisphere (especially in Australia and Antarctica), but it is less common in NorthWestern Europe and in the Tethyan realm (Lentin \& Williams, 1980; Costa \& Davey, 1992).

The presence of Heterosphaeridium difficile in all but one of the sections on Svartenhuk Halvø, in three sections in central Nuussuaq (GKP $921 \mathrm{Nall}$, GKP $92 \mathrm{~V} 1$ Qilak. \& GKP 92 V 2 Qilak. Enclosure 28, Enclosure 31 and Enclosure 32) and one section HNH 920824/2 (Enclosure 37) at Ikorfat on the north coast of Nuussuaq indicates an early/middle Turonian to early (?late) Santonian age (Haq et al., 1987; Costa \& Davey, 1992). The presence of Isabelidinium cooksoniae indicates a postearly Turonian age (Costa \& Davey, 1992).

The absence of the characteristic species Litosphaeridium siphoniphorum and Stephodinium coronatum, both of which have their last occurrence in the Turonian, the 
Fig. 9. Cretaceous palynointervals, onshore West Greenland.
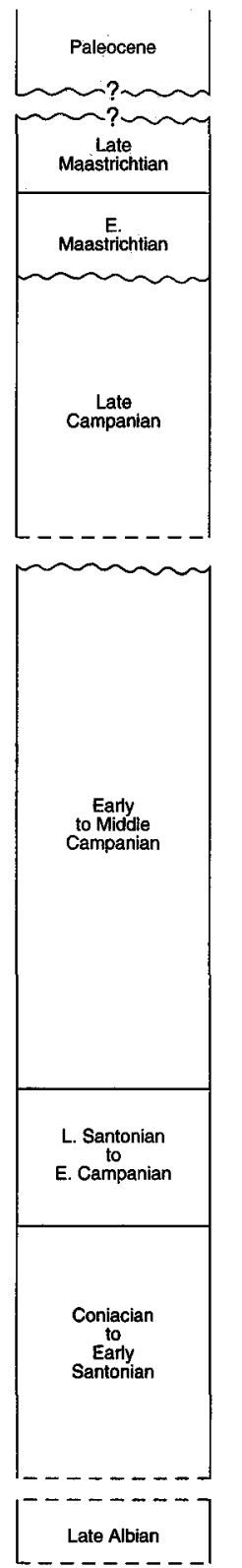
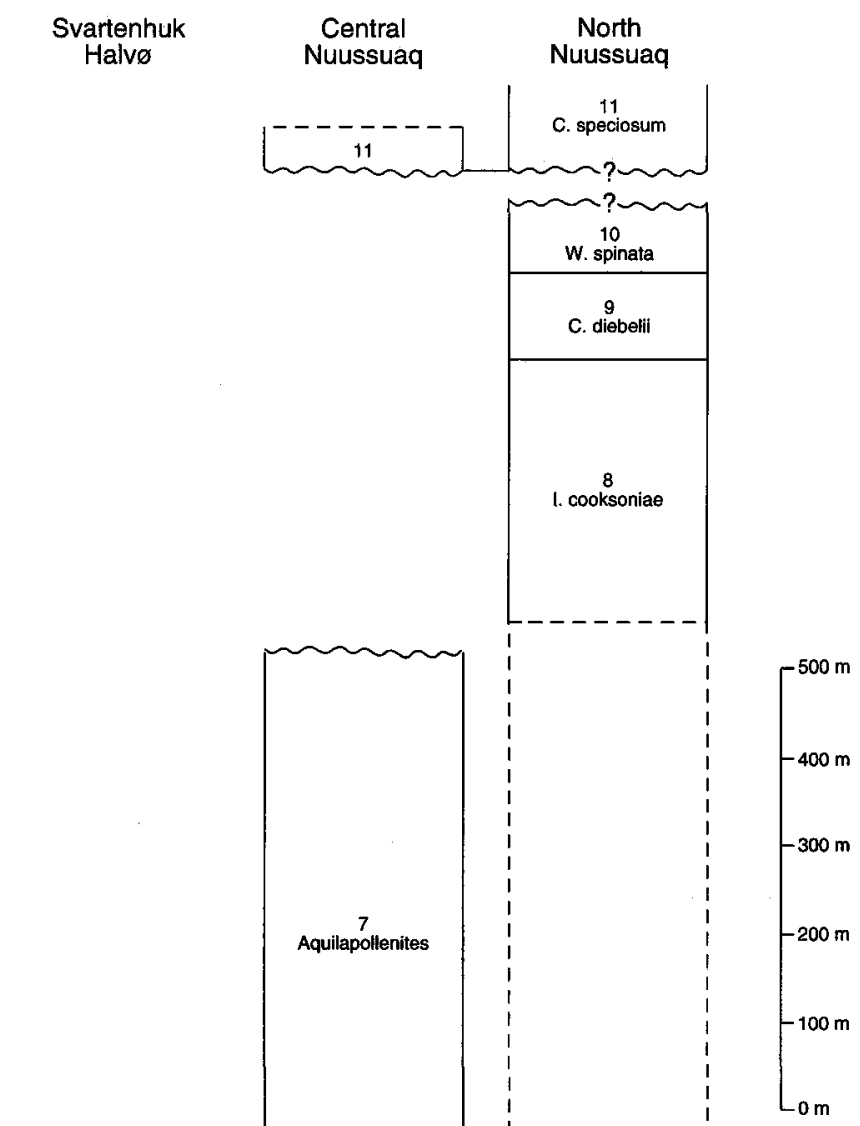

presence of Heterosphaeridium difficile and the abundance of Chatangiella specimens indicate a post-Turonian to pre-Campanian age for all the above mentioned sections.

The species list on the composite range chart for Svartenhuk Halvø (Enclosure 1) shows that the assemblage changes only little with time. However, based on the first and last occurrences of a few morphologically characteristic and stratigraphically important species, it has been possible to distinguish six dinoflagellate intervals within the Coniacian to early Santonian strata (Fig. 9).

\section{Late Santonian to middle Campanian}

Most of the Upper Cretaceous deposits on central Nuussuaq (Figs 4, 5, 10) are of late Santonian to middle Campanian age. Late Santonian or 'middle'/?late Campanian dinoflagellate cysts have been recorded from one locality on Svartenhuk Halvø (JGL Enclosure 7) and from 15 (Enclosures 14-25, 26, 27, $29 \& 30$ ) of the studied localities in central Nuussuaq. 


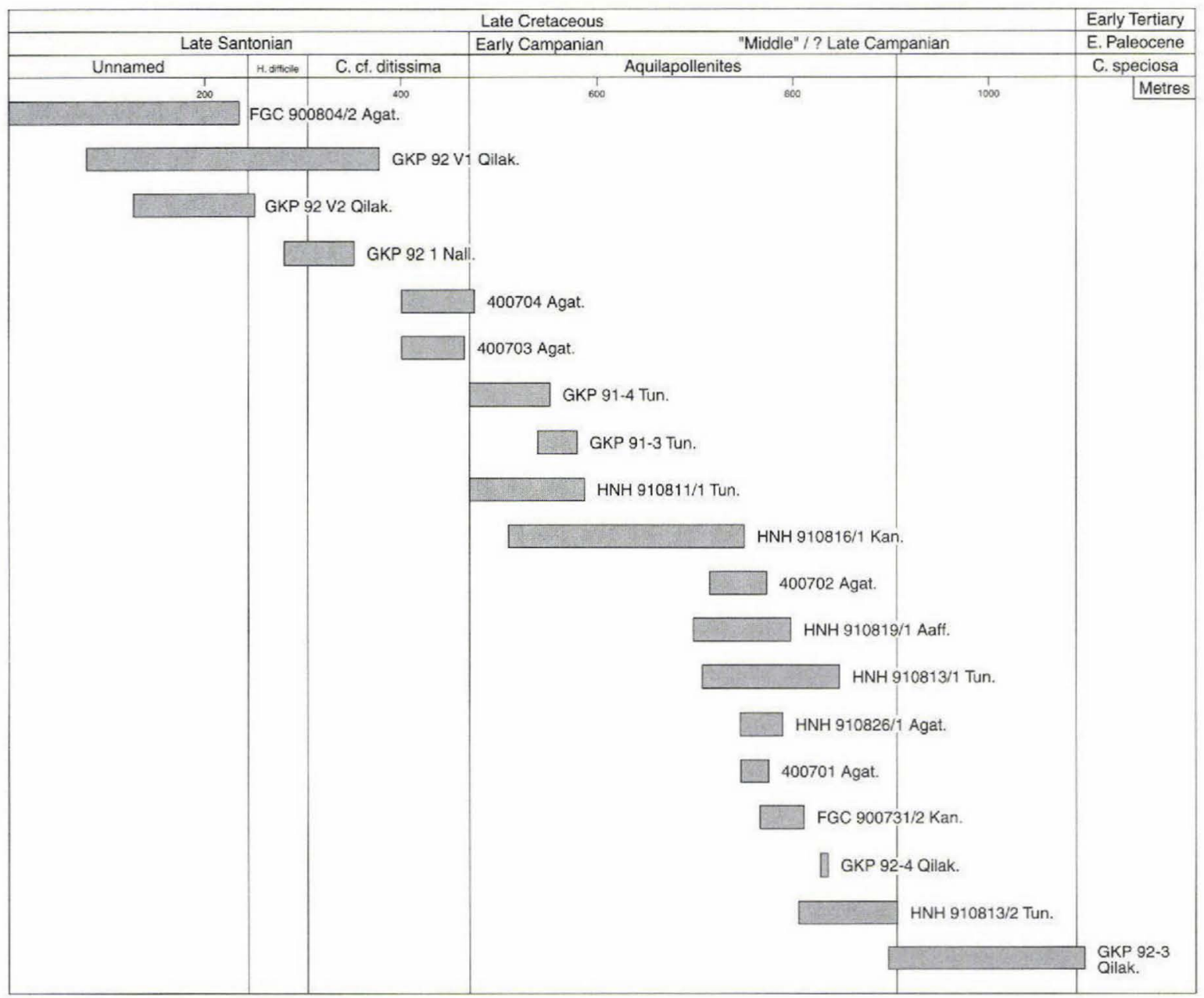

Fig. 10. Stratigraphical correlation of the sections in central Nuussuaq that yeilded dinoflagellate cysts. Kan.=Kangersooq, Agat.=Agatdalen, Qilak.=Qilakitsoq, Nall.=Nalluarissat, Tun.=Tunoqqu, Aaff.=Aaffarsuaq.

The age determination and stratigraphical correlation of this interval is based on limited observations as the dinoflagellate cyst content in the sections is very low; normally a slide contains one to ten specimens. However, terrestrially dominated samples are common. Most of the sțudied samples with marine palynomorphs contain one or more specimens of the genus Chatangiella. The presence of the pollen genus Aquilapollenites and the absence of Heterosphaeridium difficile suggests a post-?early/late Santonian age for the interval.

Aquilapollenites has been recorded in almost all of the studied sections within the interval. According to Traverse (1988) Aquilapollenites occurs sporadically from late Turonian to late Santonian, becomes consistent in the latest Santonian, and occurs through to the early Paleocene. Nichols \& Sweet (1993) recorded the first occurrence of the genus Aquilapollenites in the 'uppermost' Santonian from Yukon and Northwest Territories of Can- ada, whereas they first recorded the genus in the 'lower' Campanian in New Mexico, USA. Croxton (1980, p. 16) concluded "Although only a preliminary assessment has to date been made of the earliest occurrence of Aquilapollenites in West Greenland it is not thought to occur in strata older than Campanian in age". The fact that NøhrHansen (1994a, this paper) does not record Aquilapollenites in Coniacian to upper Santonian sediments on Svartenhuk Halvø and Nuussuaq, suggests that the genus has a post-late Santonian occurrence in West Greenland.

The presence of Isabelidinium acuminatum and I. microarmum indicates a Campanian age according to McIntyre (1975) and Costa \& Davey (1992).

The species list on the composite range chart for central Nuussuaq (Enclosure 13) shows low diversity assemblages for the late Santonian to middle Campanian described by the Aquilapollenites interval (Fig. 9). 


\section{Late Campanian to late Maastrichtian}

Marine palynomorphs of late Campanian to late Maastrichtian age have been recorded from four of the sections between Niaqornat and Ikorfat on the north coast of Nuussuaq (Figs 6, 7).

Age determination and stratigraphical correlation here is based on limited observations as the dinoflagellate cyst diversity in the sections is low and the specimens are not always well preserved. Many samples are dominated by terrestrial material.

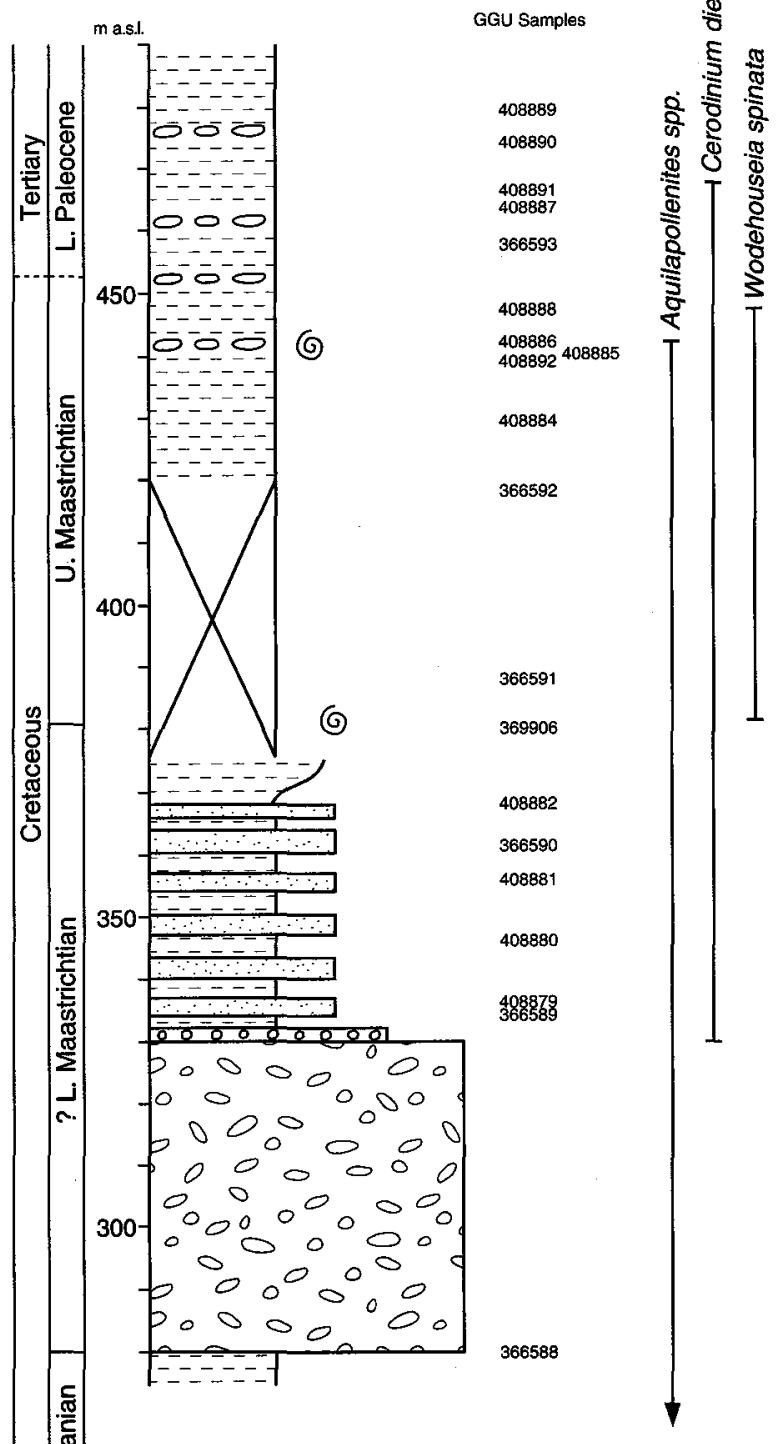

The outer shelf mudstone succession between sea level and the conspicuous 'basal Danian conglomerate' (approximately $280 \mathrm{~m}$ a.s.l.) of Rosenkrantz (1970), is here dated as late Campanian based on the absence of large Isabelidinium species and the presence of Chatangiella cf. ditissima, Odontochitina striatoperforata and Aquilapollenites (Fig. 11, Enclosure 33). The 'basal Danian conglomerate' has been interpreted as a submarine channel by Dam \& Sønderholm (1994).

Aquilapollenites has been recorded in the lower part of four of the sections, indicating a post-late Santonian age (see discussion above).

The absence of large Isabelidinium species, such as I. acuminatum and I. microarmum in sediments between Niaqornat and Ikorfat on the north coast of Nuussuaq suggests that the lowermost exposed strata in the area are younger than the early to middle Campanian strata from central Nuussuaq (Nøhr-Hansen, 1994b, this paper).

McIntyre (1975) recoreded Chatangiella ditissima consistently from Santonian to middle Campanian and sporadically from late Campanian to 'middle' Maastrichtian from the Mackenzie District area, N.W.T., Canada. According to Costa \& Davey (1992) and Williams et al. (1993) Chatangiella ditissima last occurs in the late Campanian and Odontochitina species last occur in the early Maastrichtian.

The 'basal Danian conglomerate' is approximately $50 \mathrm{~m}$ thick at Annertuneq; no palynomorphs have been recorded from this interval (Fig. 11, Enclosures 33, 38)

The Kangilia Formation includes the 'basal Danian conglomerate' and the overlying outer shelf mudstone situated below the Lower Tertiary volcanic rocks at Kangilia, and consists of approximately $500 \mathrm{~m}$ of strata (Enclosure 38). The Kangilia Formation represents a transgressive system tract, according to Dam \& Sønderholm (1994). Dam \& Sønderholm (1994, fig. 14) suggest a sequence boundary at the base of the 'basal Danian conglomerate' mudstone deposits. Their interpretation indicates a hiatus, of late Campanian to late Maastrichtian

(G) Ammonites
Sudstone
("basal Danian conglomerate")

Fig. 11. Stratigraphic log, sample position and range of stratigraphically important palynomorphs from the base of the 'basal Danian conglomerate' to the Cretaceous-Tertiary boundary at the Annertuneq section on northern Nuussuaq. 
age, situated between the Cretaceous outer shelf deposits and the conglomerate. The palynomorph content (Enclosure 33) confirms a late Campanian age for the youngest mudstone deposits situated below the 'basal Danian Conglomerate', whereas the first occurrence of the late Maastrichtian pollen Wodehouseia spinata at a level approximately $50 \mathrm{~m}$ above the top of the conglomerate at Annertuneq, suggests that the lower part of the Kangilia Formation is of early Maastrichtian age (Enclosure 33, Fig. 11).

The Kangilia Formation has previously been dated as early Paleocene to middle Paleocene by Hansen (1980, Enclosure 38) on the dinoflagellate cysts present and the interval correlated with the nannoplankton zones NP3 to NP6.

During field work in 1990-1992 ammonites were found in a loose concretion at $50 \mathrm{~m}$ and in situ at $112 \mathrm{~m}$ above the top of the conglomerate at Annertuneq (Fig 11, Enclosure 33). These new finds and the last records of the pollen genera Aquilapollenites and Wodehouseia at 112 and at $118 \mathrm{~m}$ above the conglomerate (Fig. 11, Enclosure 33) indicate that the Cretaceous-Tertiary boundary is situated at approximately $118 \mathrm{~m}$ above the top of the thick conglomerate at Annertuneq, and not at the base of it as stated by Rosenkrantz (1970) who termed it the 'basal Danian conglomerate'.

Hansen (1980, figs $14 \& 15$, p. 89) mentioned that he had no dinoflagellate cyst recovery from the lowermost $140 \mathrm{~m}$ of the Kangilia Formation but that it should not be excluded that these strata might represent the Spiniferites cryptovesiculatus Zonule (formerly Hafniasphaera cryptovesiculata) equivalent to parts of NP3 and NP4 or older strata.

Hansen (1980) recorded Aquilapollenites consistently up to $160 \mathrm{~m}$ above the conglomerate (Enclosure 38) and Croxton (1980, fig. 2) recorded Aquilapollenites and Wodehouseia up to approximately $115 \mathrm{~m}$ above the conglomerate. Croxton (1980) wrote that no conclusive statement could be made on the current palynological evidence as to whether this interval (approximately $115 \mathrm{~m}$ ) of strata above the conglomerate represents: (1) Paleocene strata, (2) Maastrichtian strata, or (3) Paleocene strata enclosing largely reworked palynomorph assemblages from different (? younger) Maastrichtian strata below the conglomerate. Neither Birkelund (1965), Croxton (1980) nor Hansen (1980) knew, as we do today, that ammonites occur in situ in the interval in question.

An extract of Hansen's (1980, fig. 15) range chart from the Annertuneq/Kangilia section (M25) is shown in Enclosure 38; this shows Hansen's zonation and the proposed correlation with the nannoplankton zones.

The find of ammonites in situ at Annertuneq confirms that the lower part of Hansen's (1980) Cerodinium stria- tum (formerly Deflandrea striata) Zonule (samples 210433-210447, Enclosure 38) in profile M25 is of latest Maastrichtian age and that the Cretaceous-Tertiary boundary may be situated in the interval between 118 and $135 \mathrm{~m}$ above the conglomerate.

Hansen's (1980, p. 123, fig. 49) correlation between dinoflagellate cyst zonation and nannoplankton zones disagrees with the occurrence of nannoplankton characteristic of NP3 recorded by Jürgensen \& Mikkelsen (1974) from samples collected just below the volcanic rocks at Annertuneq. An explanation of this disagreement is beyond the scope of the present study; renewed studies of Hansen's samples may solve the correlation problem or simply end with the conclusion that some stratigraphically important dinoflagellate cyst species have an earlier first occurrence in West Greenland than other places such as the North Sea area.

The species list on the composite range chart (Enclosure 33) shows that the assemblages of late Campanian age are of very low diversity whereas the diversity increases in the Maastrichtian. Based on the first and last occurrence and presence or absence of a few morphologically characteristic and stratigraphically important species, it has been possible to distinguish three intervals (Fig. 9) with characteristic dinoflagellate and pollen content from the composite Annertuneq section (Enclosure 33).

At Ikorfat at section FGC 900813 (Enclosure 36), the two lower samples correlate with the upper Maastrichtian strata of Annertuneq (Enclosure 33); ammonites have been sampled at the level of the uppermost sample (366623). The record of the Tertiary dinoflagellate species Isabelidinium? viborgense in the lowermost Tertiary sample (366624, Enclosure 36) situated $15 \mathrm{~m}$ above the uppermost Maastrichtian sample (366623) indicates a hiatus. Isabelidinium? virborgense has previously been reported by Hansen (1980) as Senegalinium? dilwynense from the Annertuneq section (Enclosure 38) where it has its first occurrence at approximately $180 \mathrm{~m}$ above the last ammonite.

\section{Palynological intervals}

Eleven palynofloral intervals have been distinguished in the Svartenhuk Halvø and Nuussuaq areas. Ten palynofloral intervals have been distinguished for the Coniacian/lower Santonian to upper Maastrichtian succession and one interval represents Paleocene strata.

\section{Chatangiella sp. cf. C. madura interval}

The dinoflagellate cyst assemblage recorded from the core hole GGU 400709 at Svartenhuk Halvø (Enclosure 2) 
indicates the presence of the oldest recorded marine deposition in the area.

Age. The age of the interval is most likely Coniacian but a late Turonian or early Santonian age cannot be excluded.

Definition. The interval is characterised by the occurrence of Chatangiella sp. cf. C. madura, its upper limit being the lowermost occurrence of Spinidinium echinoideum.

Thickness and distribution. The interval has only been recorded in the core hole GGU 400709 (Enclosure 2), where it is represented by approximately $75 \mathrm{~m}$ of sediments.

Characteristic species. The interval is characterised by a diverse flora. However the abundance is moderate (less than 20). The genera Chatangiella, Isabelidinium and Heterosphaeridium dominate the assemblages. The present stratigraphic important species has been recorded; Chatangiella sp. cf. C. madura, C. granulifera, C. verrucosa, Desmocysta plekta, Dinopterygium sp. aff. D. cladoides, Florentinia sp. aff. F. deanei, F. mantellii, Fromea fragilis, Heterosphaeridium difficile, Odontochitina striatoperforata, Palaeohystrichophora infusorioides, Scriniodinium sp. aff. S. obscurum, Surculosphaeridium? longifurcatum, Trigonopyxidia ginella, and Xenascus sp. aff. X. perforatus.

Discussion. According to the observations by Costa \& Davey (1992) from the North Sea region, the presence of Heterosphaeridium difficile and Surculosphaeridium? longifurcatum throughout the interval indicates an age no younger than early Santonian. Florentinia deanei has its last occurrence in the latest Coniacian in Europe (Foucher, 1979; Costa \& Davey, 1992). According to Costa \& Davey (1992) and Williams et al. (1993) Florentinia mantellii last occurs in the late Turonian. Schiøler (1992) presumed $F$. mantellii to be reworked in the Coniacian on Bornholm, Denmark, whereas Yun (1982) considered F. mantellii to be in situ in Santonian deposits in Germany.

Williams et al. (1993) reported that Chatangiella verrucosa first occurs in the early Coniacian and ranges to the late Campanian in the northern hemisphere. Williams \& Bujak (1985) reported a similar range (early Coniacian to late Campanian) for the morphologically closely related Chatangiella granulifera. McIntyre (personal communication, 1994) has recorded $C$. granulifera from Turonian in Alberta and $C$. verrucosa and $C$. granulifera from Turonian in the Mackenzie Delta area, Canada. Costa \& Davey (1992) reported an early Turonian to late Campanian range for $C$. granulifera.
Williams \& Bujak (1985) also reported an early Coniacian to late Campanian range for Trigonopyxidia ginella, which was described from the ?late Albian-Cenomanian from Australia by Cookson \& Eisenack (1960). In the present study Chatangiella sp. cf. C. madura has been recorded only from the core hole GGU 400709 (Enclosure 2). Chatangiella madura was described by Cookson \& Eisenack (1970) from Senonian of Australia. Ioannides (1986) recorded $C$. madura from the lower part of his Santonian-Campanian palynological interval I on Bylot Island, arctic Canada. Núñez-Betelu (1994) recorded the species from his Zone 2 (late Turonian to late Coniacian) and his Zone 3 (late Coniacian to early Campanian) at Glacier Fiord, arctic Canada. Kirsch (1991) reported C. madura from the lower part of his Coniacian/Santonian Raetiaedinium truncigerum Zone and from his Campanian Areoligera coronata Zone in Oberbayern, Germany, (see also systematic notes on $C$. sp. cf. C. madura below). Schiøler (1992) reported the very similar species C. tripartita from the early to 'mid'-Coniacian on the Danish island of Bornholm. Costa \& Davey (1992) reported the C. tripartita/victoriensis complex from late Cenomanian to early Maastrichtian in the North Sea region. Helby et al. (1987) reported C. tripartita from early Santonian (consistent) to 'middle' and late Santonian (inconsistent).

The absence of species with a last occurrence in the Turonian may suggest that this interval is of Coniacian age.

\section{Spinidinium echinoideum interval}

Age. Coniacian.

Definition. Interval from the first occurrence of Spinidinium echinoideum to immediately below the first occurrence of Arvalidinium scheii.

Thickness and distribution. The interval is only represented by two samples in the upper part of the core hole GGU 400709 on Svartenhuk Halvø (Enclosure 2), where it constitutes approximately $10 \mathrm{~m}$ of the section.

Characteristic species. The interval is like the Chatangiella sp. cf. C. madura interval characterised by a diverse flora. However the abundance is moderate (less than 20). The genus Chatangiella dominates the assemblages. The stratigraphically important species recorded are: Chatangiella sp. cf. C. madura, C. granulifera, C. verrucosa, Cribroperidinium sp. aff. $C$. intricatum, Florentinia sp. aff. F. deanei, F. mantellii, Fromea fragilis, Heterosphaeridium difficile, Odontochitina striatoperforata, Palaeohystrichophora infusorioides, Scriniodinium sp. aff. S. obscurum, Spinidinium echinoideum and Surculosphaeridium? longifurcatum. 
Discussion. The first occurrence of Spinidinium echinoideum in the upper part of the core hole GGU 400709 (Enclosure 2) indicates a Coniacian to early Santonian age. The species was described by Cookson \& Eisenack (1960) from the Santonian and Campanian in Australia. According to Clarke \& Verdier (1967) and Foucher (1979) Spinidinium echinoideum ranges from the early Santonian to the earliest Campanian in England and France. However, Foucher (1979) reported in addition a $S$. sp. cf. S. echinoideum from the late Turonian in France. Schiøler (1992) recorded S. echinoideum echinoideum from Coniacian deposits from the island of Bornholm, Denmark. From Oberbayern in Germany Kirsch (1991) recorded the first occurrence for S. echinoideum in his Coniacian to Santonian Raetiaedinium truncigerum Zone. HeilmannClausen (1985) recorded S. echinoideum from the early Paleocene in Denmark. Spinidinium mariae is considered here to be almost identical with $S$. echinoideum. According to Aurisano $(1984,1989)$ Spinidinium mariae ranges from early Santonian to early Campanian in the Atlantic coastal plain of New Jersey, U.S.A.

\section{Arvalidinium scheii interval}

Age. The age of the interval is most likely early Coniacian, due to its position in the core hole GGU 400712, where it has been recorded below in situ ammonites of early Coniacian age (Birkelund, 1965).

Definition. Interval from the first occurrence of Arvalidinium scheii to immediately below the first occurrence of Laciniadinium arcticum.

Thickness and distribution. The interval is represented by the lower $57 \mathrm{~m}$ of the core hole GGU 400712 on Svartenhuk Halvø (Enclosure 8) and perhaps by the two lowermost samples (approximately $40 \mathrm{~m}$ ) from section $\mathrm{C12}$, Svartenhuk Halv $\emptyset$ (Enclosure 12). The interval is possibly also represented by one sample from section $\mathrm{HNH}$ 920824/2 Nnuu (Enclosure 37) at Ikorfat on the north coast of Nuussuaq.

Characteristic species. The interval is characterised by the presence of numerous Arvalidinium and Chatangiella specimens, which constitute between 35 and 53\% of the dinoflagellate cyst assemblages, and Odontochitina striatoperforata, which constitutes up to $10 \%$ of the assemblage. The interval is also characterised by the incoming of the species Arvalidinium scheii, Chatangiella mcintyrei sp. nov., Isabelidinium svartenhukense sp. nov. and Palaeotetradinium silicorum. The following characteristic species continue from the previous Spinidinium echinoideum interval: Chatangiella granulifera, $C$. verruco- sa, Desmocysta plekta, Dorocysta litotes, Florentinia sp. aff. F. deanei, F. mantellii, Fromea fragilis, Heterosphaeridium difficile, Odontochitina striatoperforata, Palaeohystrichophora infusorioides, Spinidinium echinoideum, Surculosphaeridium? longifurcatum, Trigonopyxidia ginella, Trithyrodinium suspectum, Wallodinium anglicum and Xenascus sp. aff. X. perforatus.

Discussion. The abundance of Arvalidinium scheii in the interval is important. Previously A. scheii has only been reported by Manum (1963) who described the species (as Deflandrea scheii) from a 'Deflandreoid'-dominated assemblage from Graham Island, arctic Canada, where according to Manum (1963) and Manum \& Cookson (1964) it is very common. The dinoflagellate cyst assemblage from the sample reported by Manum \& Cookson (1964) from the presumed Kanguk Formation at Graham Island is quite similar to the assemblage recorded from the A. scheii interval on Svartenhuk Halvø. However Laciniadinium arcticum (as Diconodinium arcticum) which occurs on Graham Island has not been observed in the $A$. scheii interval on Svartenhuk Halvø. Manum (1963) and Manum \& Cookson (1964) indicated that their samples were from the upper Albian - lower Cenomanian Hassel Formation, but Felix \& Burbridge (1976) considered that Manum's samples more likely represented the Kanguk Formation of late Cenomanian to early Campanian age. Núñez-Betelu (1994) described some forms resembling A. scheii, from the base of his late Coniacian to early Campanian Zone 3; the level was dated late Coniacian by the presence of the ammonite Scaphites depressus (Hills et al., 1994).

\section{Laciniadinium arcticum interval}

Age. The age of the interval is most likely early Coniacian, due to its position at the core hole GGU 400712 (Enclosure 8) where it has been recorded below in situ ammonites of early Coniacian age (Birkelund, 1965).

Definition. Interval from the first occurrence of Laciniadinium arcticum to the last occurrence of Arvalidinium scheii.

Thickness and distribution. The interval is represented by approximately $50 \mathrm{~m}$ in the core hole GGU 400711 (Enclosure 10), approximately $50 \mathrm{~m}$ in section $\mathrm{C} 12$ Svartenhuk (Enclosure 12), approximately $20 \mathrm{~m}$ in the composite section GGU 400712+HNH 920821/1 (Enclosure 8) and possibly by one sample in section HNH920822/3 Svar (Enclosure 6). All sections from Svartenhuk Halvø.

Characteristic species. The interval is, like the underly- 
ing interval, characterised by the presence of numerous Chatangiella specimens. The interval is also characterised by the incoming of Laciniadinium arcticum. Microdinium reticulatum, Tanyosphaeridium $\mathrm{sp}$. cf. T. variecalamus. The following species continue from the Arvalidinium scheii interval: Arvalidinium scheii, Chatangiella sp. aff. C. spectabilis, $C$. sp. cf. C. ditissima, Spinidinium echinoideum, C. granulifera, $C$. verrucosa, Desmocysta plekta, Florentinia sp. aff. F. deanei, F. mantellii, Fromea fragilis, Heterosphaeridium difficile, Odontochitina striatoperforata, Palaeohystrichophora infusorioides, Surculosphaeridium? longifurcatum, Trigonopyxidia ginella, Trithyrodinium suspectum, Wallodinium anglicum and Xenascus sp. aff. $X$. perforatus. The last occurrence of Palaeotetradinium silicorum is in the lower part of the interval.

Discussion. The palynomorph assemblage of the interval is very similar to the 'Deflandreoid'-dominated assemblage from Graham Island, arctic Canada, recorded by Manum (1963) and Manum \& Cookson (1964). In addition to the abundance of Arvalidinium scheii and the presence of Laciniadinium arcticum there are 15 other species from the interval that are also present in the Graham Island samples. The interval correlates with the upper part of Zone 2 (late Turonian to late Coniacian) or the lower part of Zone 3 (late Coniacian to early Campanian) described by Núñez-Betelu (1994) for the Kanguk Formation in the Canadian arctic.

\section{Notes on the Laciniadinium arcticum/ Heterosphaeridium difficile interval}

Samples from three sections on central Nuussuaq have been very difficult to place in one of the 10 defined Upper Cretaceous intervals due to the presence of very few dinoflagellate cysts. Possibly the entire section FGC900804/2 Kan. (Enclosure 26; $110 \mathrm{~m}$ ), the lower part of section GKP $92 \mathrm{~V} 1$ Qilak. (Enclosure 31;120 m) and GKP 92 V 2 Qilak. (Enclosure 32; $96 \mathrm{~m}$ ) belong in this interval.

The samples from the three sections mentioned above contain almost no dinoflagellate cysts exept for a few specimens of the genera Chatangiella and Isabelidinium. The presence of Isabelidinium and Chatangiella, especially $C$. granulifera, indicates an early Coniacian to late Campanian range according to Williams \& Bujak (1985), whereas Costa \& Davey (1992) reported an early Turonian to late Campanian range for $C$. granulifera.

The fact that the samples from the sections GKP $92 \mathrm{~V}$ 1 Qilak. (Enclosure 31) and GKP 92 V 2 Qilak. (Enclosure 32) are situated stratigraphically below samples containing the species Heterosphaeridium difficile suggest that the interval may correlate with part of the Laciniadinium articum interval or part of the $H$. difficile interval.

\section{Heterosphaeridium difficile interval}

Age. Coniacian to early Santonian

Definition. Interval from immediately above the last occurrence of Arvalidinium scheii to the last occurrence of Heterosphaeridium difficile.

Thickness and distribution. The interval is represented in six outcrop sections and two subsurface sections in the Svartenhuk Halvø area, three sections in the central Nuussuaq area and in one section at Ikorfat at the north coast of Nuussuaq. The interval is represented by $94 \mathrm{~m}$ in the composite section GGU 400708+HNH 920806/1 (Enclosure 3), $16 \mathrm{~m}$ in section HNH 920809/1 Svar (Enclosure 4), section HNH 920822/2 Svar (Enclosure 5), perhaps from the uppermost sample in section $\mathrm{HNH}$ 920822/3 Svar (Enclosure 6), $15 \mathrm{~m}$ in section $\mathrm{HNH}$ 920822/5 Svar (Enclosure 9), $71 \mathrm{~m}$ in the composed section GGU 400710+FGC 910807/2 (Enclosure 11) and by approximately $60 \mathrm{~m}$ in section C12 (Enclosure 12) on Svartenhuk Halvø. The interval is represented by one sample in each of the sections GKP 92 V 2 Qilak. (Enclosure 32) and GKP 921 Nall. (Enclosure 28) and constitutes approximately $95 \mathrm{~m}$ of the section GKP $92 \mathrm{~V} 1$ Qilak. (Enclosure 31) in the central Nuussuaq area. The interval is probably also represented by the uppermost sample from section HNH 920824/2 Nnuu (Enclosure 37) at Ikorfat on the north coast of Nuussuaq.

Characteristic species. The interval is characterised by a poorly preserved low diversity palynomorph assemblage. The frequency of Chatangiella specimens is very low compared to the previous zone. Species such as Chatangiella sp. cf. C. ditissima, Heterosphaeridium difficile, Laciniadinium arcticum, Odontochitina striatoperforata, Palaeohystrichophora infusorioides and Spinidinium echinoideum are present throughout the zone, whereas Isabelidinium svartenhukense sp. nov., Surculosphaeridium? longifurcatum, Trigonopyxidia ginella and Wallodinium anglicum are recorded only from the lower part of the interval. The following species have a more sporadic occurrence within the interval: Chatangiella granulifera, C. sp. aff. C. spectabilis, Desmocysta plekta, Florentinia sp. aff. F. deanei, F. mantellii and Xenascus sp. aff. $X$. perforatus.

Discussion. The last occurrences of Heterosphaeridium difficile and Surculosphaeridium? longifurcatum indicate an age no younger than early Santonian, in agreement 
with the range given by Costa \& Davey (1992). Based on the last occurrence of $H$. difficile, the interval may be correlated with the lower part of the late Coniacian to early Campanian Zone 3 described for the Kanguk Formation in arctic Canada by Núñez-Betelu (1994).

\section{Dinogymnium sp. cf. $D$. sibiricum interval}

Age. Late Santonian or early Campanian

Definition. Interval from immediately above the last occurrence of Heterosphaeridium difficile up to the last occurrence of Dinogymnium sp. cf. $D$. sibiricum.

Thickness and distribution. The interval has been recorded only in the three metre thick section JLG on Svartenhuk Halvø (Enclosure 7) situated just below the base of the hyaloclastic basalt.

Characteristic species. The interval is represented by a low diversity palynomorph assemblage, characterised by well preserved specimens of Isabelidinium sp. aff. I. acuminatum, and very few specimens of Dinogymnium sp. cf. $D$. sibiricum. The following stratigraphically important species continue from previous zones: Chatangiella sp. cf. C. ditissima, Palaeohystrichophora infusorioides, Spinidinium echinoideum, Trithyrodinium suspectum and Xenascus sp. aff. $X$. perforatus.

Discussion. The presence of Chatangiella sp. cf. C. ditissima, Palaeohystrichophora infusorioides and Trithyrodinium suspectum indicates, according to Costa \& Davey (1992), an age no younger than Campanian. The same authors mention that Isabelidinium acuminatum first occurs, or first becomes consistent in the early Campanian. Dinogymnium sibiricum has a Coniacian to early Santonian range, according to Costa \& Davey (1992), whereas McIntyre (1974) reported a late Santonian to late Campanian range for the almost identical species Dinogymnium sp. cf. Dinogymnium sibiricum.

The discussion above clearly illustrates the difficulties in dating the interval. However the absence of Heterosphaeridium difficile and the presence of Spinidinium echinoideum indicate a late Santonian/early Campanian age.

\section{Notes on an almost barren interval above the Heterosphaeridium difficilel Dinogymnium sp. cf. D. sibiricum interval}

Samples from two sections and two core holes in central Nuussuaq are almost barren of dinoflagellate cysts and only characterized by occupying an interval between the last occurrence of Heterosphaeridium difficile and below the first occurrence of Aquilapollenites. The inter$\mathrm{val}$ is represented by one sample each in the two sections GKP 92 V 1 Qilak. (Enclosure 31), GKP 921 Nall. (Enclosure 28), $59 \mathrm{~m}$ of the core hole GGU $400703 \mathrm{Cnuu}$ (Enclosure 17) and by the lower $40 \mathrm{~m}$ in the core hole GGU 400704 Cnuu (Enclosure 18).

The samples contain a few specimens of the characteristic species Chatangiella sp. cf. C. ditissima, $C$. sp. cf. C. spectabilis, Florentinia mantellii, Fromea fragilis, Isabelidinium spp., Laciniadinium aff. L. arcticum, Odontochitina striatoperfarata and Spinidinium aff. S. uncinatum.

The fact that the samples from the core hole GGU 400704 Cnuu (Enclosure 18) are situated stratigraphically below samples containing Aquilapollenites suggests that the interval may correlate with part of the $H$. difficile interval or part of the Dinogymnium sp. D. sibiricum interval and be of Late Santonian or early Campanian age.

\section{Aquilapollenites interval}

Age. Early to middle Campanian

Definition. The interval is defined from the first occurrence of species of Aquilapollenites to the last occurrence of Isabelidinium microarmum.

Thickness and distribution. The interval is recorded only from central Nuussuaq. The interval is represented in the following 13 sections: FGC900731/2 Agat. (Enclosure 14; $50 \mathrm{~m}$ ), core hole GGU 400701 Cnuu. (Enclosure 15; $60 \mathrm{~m}$ ), core hole GGU $400702 \mathrm{Cnuu}$. (Enclosure 16; $55 \mathrm{~m}$ ), core hole GGU 400704 Cnuu (Enclosure 18; uppermost sample), HNH910826/1 (Enclosure 19; 35 m), GKP 914 Tun. (Enclosure 20; $86 \mathrm{~m}$ ), GKP 913 Tun. (Enclosure 21; $38 \mathrm{~m}$ ), HNH910811/1 (Enclosure 22; one sample), HNH910813/1 (Enclosure 23; $90 \mathrm{~m}$ ), HNH910813/2 (Enclosure 24; $95 \mathrm{~m}$ ), HNH910816/1 (Enclosure 25; 155 m), HNH910819/1 (Enclosure 27; 100 m), GKP 923 Qilak. (Enclosure 29; one sample) and from section GKP 924 Qilak. (Enclosure 30; one sample) all situated in central Nuussuaq.

Characteristic species. The first occurrence of Aquilapollenites is diagnostic for the interval. The diversity is low and the dinoflagellate cyst content is poor in the lower part of the interval, a few specimens of $C$. granulifer $a$ and Laciniadinium arcticum have been recorded from section GKP 914 Tun. (Enclosure 20). Batioladinium jaegeri appears to be reworked in section GKP 914 Tun. (Enclosure 20). The diversity is higher in the lower middle and upper part of the interval (Enclosure 39). Chatangiella bondarenkoi and Isabelidinium acuminatum have their 
first occurrences in the lower middle part of the Aquilapollenites interval whereas $I$. microarmum has its first occurrence in the upper part of the interval. Other characteristic species from the middle and upper part of the interval are Aquilapollenites spp., Chatangiella sp. cf. C. ditissima, C. granulifera, Desmocysta plekta, Exochosphaeridium bifidum, E. striolatum, Hystrichosphaeridium pulchrum, Laciniadinium arcticum, Odontochitina striatoperforata and a single specimen of Coronifera oceanica, Florentinia mantellii, Palaeohystrichophora infusorioides, Surculosphaeridium sp. aff. S. longifurcatum and Tanyosphaeridium sp. cf. T. variecalamus.

Discussion. According to Traverse (1988) Aquilapollenites becomes consistent in the 'latest' Santonian and through to the early Paleocene. Aquilapollenites species have not been recorded in sediments older than middle to late Campanian at Horton River northern Canada (McIntyre, 1974). Sweet et al. (1989) recorded the first occurrence of Aquilapollenites species in the early Campanian in the Brackett Basin, N.W.T., Canada, whereas Nichols \& Sweet (1993) mentioned that Aquilapollenites species have their first occurrence in the 'latest' Santonian in Yukon and N.W.T., Canada. On Svartenhuk Halvø Aquilapollenites was not recorded in the Coniacian to late Santonian succession by Nøhr-Hansen (1994a), which suggests that the genus has a post-late Santonian occurrence in West Greenland.

Based on the first occurrence of Aquillapollenites spp., the interval may be correlated with the upper part of the late Coniacian to early Campanian Zone 3 described for the Kanguk Formation in arctic Canada by Núñez-Betelu (1994).

According to Costa \& Davey (1992) Batioladinium jaegeri has its last occurrence in the middle Cenomanian. The presence of possibly reworked specimens of $B$. jaeger $i$ in the Campanian section GKP 914 Tun (Enclosure 20) indicates that pre-Turonian marine-influenced sediments have been deposited somewhere in central Nuussuaq.

Isabelidinium acuminatum has an early to 'middle' Campanian range in the Mackenzie Delta area (McIntyre, 1975). Harker et al. (1990) recorded I. acuminatum from the earliest Campanian in the Western Interior, U.S.A. According to Costa \& Davey (1992) I. acuminatum first occurs, or first becomes consistent in the early Campanian. Previously $C$. bondarenkoi has been reported from Santonian in Western Siberia and from Santonian to Campanian in arctic Canada (Lentin \& Vozzhennikova, 1990).

Isabelidinium microarmum has an early Campanian to 'middle' Maastrichtian range in the Horton River section (McIntyre, 1975). Ioannides (1986) recorded I. microarmum from questionable Maastrichtian strata in arctic Canada. According to Costa \& Davey (1992) I. microar- mum does not seem to persist beyond the end of the Campanian in the North Sea region.

Odontochitina striatoperforata was described from the Albian to Cenomanian in Australia by Cookson \& Eisenack (1962). Williams \& Brideaux (1975) recorded a Cenomanian to 'latest' Campanian range for the species from Grand Banks, offshore eastern Canada. Singh (1971) has been followed concerning the systematic position of o. striatoperforata.

The presence of Palaeohystrichophora infusorioides and Chatangiella granulifera indicates a pre-Maastrichtian age (Costa \& Davey, 1992).

The presence of single specimens of Tanyosphaeridium sp. cf. $T$. variecalamus and $S$. sp. aff. $S$. longifurcatum suggests a pre-Campanian age. The single specimen occurrences suggest, however, that the species may be reworked or that they have a slightly longer range in West Greenland.

An early to 'middle' Campanian age is proposed for the Aquilapollenites interval based on the first occurrences of Aquilapollenites, Isabelidinium acuminatum and I. microarmum.

\section{Isabelidinium cooksoniae interval}

The sparse dinoflagellate cyst assemblage recorded from the I. cooksoniae interval (Enclosures 33, 34, 35) indicates the presence of the oldest recorded marine deposits between Niaqornat and Ikorfat on the north coast of Nuussuaq.

Age. The age of the interval is most likely late Campanian.

Definition. The interval is defined by the abundance of Isabelidinium cooksoniae and Palaeoperidinium pyrophorum, the upper limit being immediately below the first occurrence of Cerodinium diebelii.

Thickness and distribution. Approximately $280 \mathrm{~m}$ of composite strata in the core holes GGU 400705, 400706, 400707 (Fig. 7, Enclosure 33) and sediments below the conspicuous conglomerate at the north coast of Nuussuaq (Enclosures 33, 34, 35) are described as the I. cooksoniae interval.

Characteristic species. The interval is characterised by the abundance of Isabelidinium cooksoniae and Palaeoperidinium pyrophorum, and by the presence of Chatangiella sp. cf. C. ditissima, Laciniadinium arcticum, Odontochitina striatoperforata, and Aquilapollenites. Only a few specimens of the genera Hystrichodinium and Xenascus have been recorded. Fibrocysta? vectensis sensu Ioannides (1986) has been recorded only from the upper- 
most part of the interval at Annertuneq (Enclosure 33), and 'Isabelidinium sp. aff. I. bujakii' Marheinecke (1992) first occurs in the same interval.

Discussion. The presence of Aquilapollenites indicates an age not older than 'latest' Santonian or 'earliest' Campanian (see discussion above). According to Costa \& Davey (1992), Williams et. al (1993) and Williams \& Brideaux (1975) the presence of Chatangiella sp. cf. $C$. ditissima and Odontochitina striatoperforata indicates a pre-early Maastrichtian age. The absence of $I$. acuminatum and $I$. microarmum in the interval suggests an assemblage younger than the early to 'middle' Campanian assemblages described above and by Nøhr-Hansen (1994b) from central Nuussuaq.

\section{Cerodinium diebelii interval}

Age. Early Maastrichtian.

Definition. The interval is defined as being from the first occurrence of Cerodinium diebelii to immediately below the first occurrence of the pollen species Wodehouseia spinata.

Thickness and distribution. The interval is represented in the Annertuneq section (Enclosure 33) by approximately $46 \mathrm{~m}$, in the Kangilia HN-H section (Enclosure 34) by one sample, in section FGC $900813 / 7$ Nord (Enclosure 36) by one sample and in section HNH 910718/1 (Enclosure 35) by more than $30 \mathrm{~m}$. All four sections are situated on the north coast of Nuussuaq.

Characteristic species. The interval is characterised by the first occurrence of Cerodinium diebelii, Paleocystodinium golzowense, Impagidinium sp. cf. I. dispertitum, the informal subspecies 'Hystrichosphaeridium proprium proprium' erected by Marheinecke (1992) and by the presence of 'Isabelidinium sp. aff. I. bujakii' Marheinecke (1992) and representatives of the pollen genus Aquilapollenites. The lowermost sample (366589), representing the interval at Annertuneq (Enclosure 33), is dominated by ' $H$. $p$. proprium' and Chatangiella sp. aff. $C$. granulifera of which the latter may be reworked. The species Chatangiella sp. cf. C. ditissima, Isabelidinium cooksoniae, Laciniadinium arcticum and Odontochitina striatoperforata, when they occur, are recorded only from the lowermost part of the interval.

Discussion. The first occurrence of Cerodinium diebelii (see also discussion in the notes to $C$. diebelii) has previously been reported from early Maastrichtian in arctic Canada (McIntyre, 1975) and from the Atlantic Coastal
Plain of U.S.A. (Aurisano, 1989), whereas Williams, et al. (1993) reported a late Santonian first occurrence for C. diebelii in the Northern Hemisphere, Kirsch (1991) recorded a early to late Maastrichtian age from Oberbayern, Germany and Costa \& Davey (1992) reported a late Campanian first occurrence from the North Sea area.

The informal species 'Isabelidinium bujakii' was described and reported only from the latest early Maastrichtian in Germany by Marheineche (1992). According to Costa \& Davey (1992) and Williams et al. (1993) Chatangiella ditissima has its last occurrence in the 'uppermost' Campanian and Odontochitina species last occurs in the 'lowermost' Maastrichtian.

Ioannides (1986) recorded $P$. golzowense from the lowermost part of his Maastrichtian interval III and from his early Paleocene IV and IVa intervals on Bylot Island, arctic Canada.

The first occurrence of Cerodinium diebelii and the last occurrence of Chatangiella sp. aff. C. ditissima and o. striatoperforata in the lowermost part of the interval, and the presence of ' $I$. sp. aff. I. bujakii' throughout the interval, suggest an early Maastrichtian age.

\section{Wodehouseia spinata interval}

Age. Late Maastrichtian.

Definition. The interval is defined as being from the first occurrence of the pollen species Wodehouseia spinata to its last occurrence.

Thickness and distribution. The interval is recorded only from the north coast of Nuussuaq where it is represented by approximately $80 \mathrm{~m}$ in the Annertuneq section (Enclosure 33), by approximately $70 \mathrm{~m}$ in the Kangilia $\mathrm{HN}-\mathrm{H}$ section (Enclosure 34), and by approximately $25 \mathrm{~m}$ in section FGC 900813/7 Nord (Enclosure 36) at Ikorfat.

Characteristic species. The interval is characterised by Wodehouseia spinata. The following dinoflagellate cyst species first occur in the interval: Deflandrea galeata, 'Hystrichosphaeridium proprium brevispinum' of Marheineche (1992) and Phelodinium kozlowskii. The species Cerodinium diebelii, 'H. p. proprium' and Palaeocystodinium golzowense are present throughout the interval.

Spinidinium clavus is abundant in the lowermost sample of the interval in the Annertuneq section. The pollen of Pseudointegricorpus protusum, Scollardia sp., Wodehouseia sp. cf. W. fimbriata and W. sp. cf. W. quadrispina are rare but have been recorded only from this interval in this study. 
Discussion. According to Nichols \& Sweet (1993, fig. 3a, table. 1) Wodehouseia spinata has its lowest occurrence in their assemblage 9 (lower part of late Maastrichtian) from the Westem Interior, U.S.A. and has a stratigraphical range from the late Maastrichtian to the CretaceousTertiary boundary in the Yukon and Northwest Territories of Canada and in New Mexico, U.S.A. However, the species crosses this boundary in the northern part of the Western Interior Basin (Nichols \& Sweet, 1993, p. 551). Srivastava (1994) reported the last occurrence of $W$. spinata less than a metre above the Cretaceous-Tertiary boundary in Alberta, Canada. McIntyre (1974) recorded W. spinata in sediments of Maastrichtian age in the Horton River section, arctic Canada.

The presence of a few specimens of Wodehouseia sp. cf. W. quadrispina in the uppermost part of the W. spinata interval indicates, according to the work of Nichols \& Sweet (1993), a 'latest' Maastrichtian age.

The occurrence of Wodehouseia sp. cf. W. fimbriata in the concretion surrounding the ammonite sample 408892 (Enclosure 33) is noteworthy. Sweet et al. $(1989$, p. 98) wrote that the occurrence of Wodehouseia fimbriata started at an horizon about $22 \mathrm{~m}$ above the Cretaceous-Tertiary boundary at Police Island in the Northwest Territories of Canada, and the same first occurrence for W. fimbriata was shown by Nichols \& Sweet (1993, fig. 5). Srivastava (1994) recorded W. fimbriata as abundant in a sample approximately $3.5 \mathrm{~m}$ above the Cretaceous-Tertiary boundary in Alberta. However A. R. Sweet (personal communication, 1994) confirmed that specimens similar to the Wodehouseia sp. cf. W. fimbriata specimens from West Greenland have been recorded from the 'latest' Maastrichtian in the Western Interior, and the pollen assemblages of the samples 408886 and 408892 suggest a 'latest' Maastrichtian age.

According to Schiøler \& Wilson (1993, p. 343) Deflandra galeata has a first occurrence in the middle part of the late Maastrichtian Isabelidinium cooksoniae Interval Zone in the Danish part of the North Sea. Schiøler \& Wilson show that D. galeata and I. cooksoniae occur together in their interval zone, and that $I$. cooksoniae was abundant in this interval. However I. cooksoniae has not been recorded together with $D$. galeata in West Greenland. Kirsch (1991) recorded D. galeata from middle to late Maastrichtian deposits in Oberbayern, Germany.

\section{Cerodinium speciosum interval}

Age. Late Paleocene.

Definition. The interval is defined as ranging from immediately above the last occurrence of Wodehouseia spinata.

Thickness and distribution. The interval is recorded from the upper part of three sections (Annertuneq, HNH 910718/1, Enclosure 35 and FGC 900813/7 Nord, Enclosure 36) on the north coast of Nuussuaq and the uppermost sample of section GKP 923 Qilak in central Nuussuaq (Enclosure 29). The lowermost sample in this section represents the early to middle Campanian Aquilapollenites interval, and the approximately $200 \mathrm{~m}$ of strata between the two samples are barren of dinoflagellate cysts.

Characteristic species. The interval is characterised by first occurrence of Cerodinium speciosum, Deflandrea aff. D. galeata and by the presence of the species Phelodinium kozlowskii and Glaphyrocysta sp. Dark brown specimens of the Jurassic species Cribroperidinium? perforans constitute up to $30 \%$ of the dinoflagellate assemblage in the lowermost sample of the interval at Annertuneq, and are considered as reworked.

Discussion. The species Cerodinium speciosum dates the sample as late Paleocene. In and around Great Britain the base of the range of the species correlates with NP5 (Heilmann-Clausen, 1985; Powell, 1992).

The $200 \mathrm{~m}$ of strata between the sample containing I. microarmum and the sample with $C$. speciosum (Enclosure 29) may represents the entire upper Campanian to upper Paleocene stratigraphic column. However it is considered more likely that there is a non-conformity within the strata between the two samples. 


\section{Comparison with macrofossil ages}

\section{Svartenhuk Halvø}

Late Turonian, Coniacian, Santonian and early Campanian ammonites on south-east Svartenhuk Halvø (Fig. 12) were recorded by Birkelund (1965; fig. 2, table 1) in her monograph on Upper Cretaceous ammonites from West Greenland. The ammonite record was correlated with other macrofossil records by Rosenkrantz \& Pulvertaft (1969) in their review of Cretaceous-Tertiary stratigraphy and tectonics in northern West Greenland.

Birkelund (1965) recorded in situ ammonites indicating the presence of lower Coniacian deposits at the ammonite locality at Umiivik. This locality corresponds to the uppermost part of the core hole GGU 400712 Svar (Enclosure 8) which has been referred to the Laciniadinium arcticum interval (Coniacian) of this study. From the same locality Birkelund (1965) recorded ammonites of Santonian and early Campanian ages in displaced blocks.

The loose, possibly reworked, specimens of ammonites recorded from the Store Tange V locality at Umiivik indicate a late Turonian age (Birkelund, 1965). This locality corresponds to the locality $\mathrm{C} 12$ Svartenhuk (Enclosure 12) collected by Catherine A. Croxton which, according to the dinoflagellates recorded here, is of Coniacian or early Santonian age. At Lille Tange V a little north of the Store Tange V locality Birkelund (1965) recorded ammonites of early Santonian age in situ at 180-200 $\mathrm{m}$ above sea level, which correlate well with the age indicated by dinoflagellates from the upper part of section C12 Svartenhuk (Enclosure 12).

\section{Central Nuussuaq}

Santonian, Campanian and Maastrichtian ammonites in central Nuussuaq (Fig. 13) were recorded by Birkelund
(1965; fig. 2, table 1). Birkelund (1965) recorded ammonites suggesting the presence of Santonian deposits at the Nordre Baculiteskløft locality in Agatdalen. This locality is very close to the core hole GGU 400704 Cnuu (Enclosure 18). In this study a late Santonian age to early Campanian is proposed. From the Scaphitesnæesen locality Birkelund (1965) recorded ammonites of early Campanian age. The section FGC900731/2 (Enclosure 14) from Agatdalen is from the same locality, and the dinoflagellate assemblage from Scaphitesnæsen suggests an early or ?'middle' Campanian age.

The ammonites recorded from Tunogqu and Ilugissoq ( $5 \mathrm{~km}$ west of Qilikitsoq) in central Nuussuaq (Fig. 5) indicate an early Santonian age (Birkelund, 1965). The dinoflagellate cyst assemblage from the section GKP 92 V 2 Qilak. (Enclosure 32), which may be the same as Birkelund's (1965) Ilugissoq section, suggests a late Santonian age. The studied sections from Tunoqqu (Enclosures 20-25) contain dinoflagellate cysts suggesting an early or 'middle' Campanian age.

\section{Northern Nuussuaq}

Santonian, Campanian and Maastrichtian ammonites between Niaqornat and Ikorfat on the north coast of Nuussuaq (Fig. 14) were recorded by Birkelund (1965; table 1, plate 48). Birkelund (1965) recorded ammonites indicating the presence of Santonian deposits at the Tupersuartaa locality (Fig. 6); all organic material from this area is thermally overmature. The record of late Campanian and Maastrichtian ammonites (Birkelund, 1965) between Scaphiteskløften and Skiferperidotitnæsen at Kuuk Anernilik (Fig. 6) correlates with the study of palynomorphs from the Annertuneq section (Enclosure 33), the Kangilia HN-H section (Enclosure 34) and the

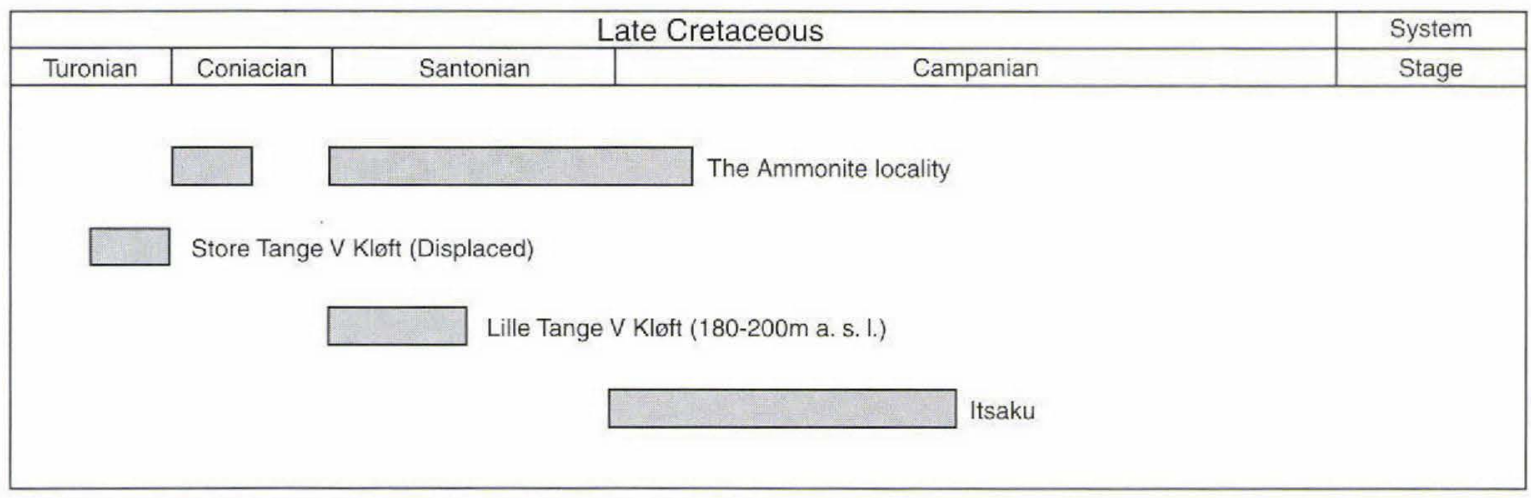

Fig. 12. Ammonite dates at Svartenhuk Halvø obtained from Birkelund (1965). 


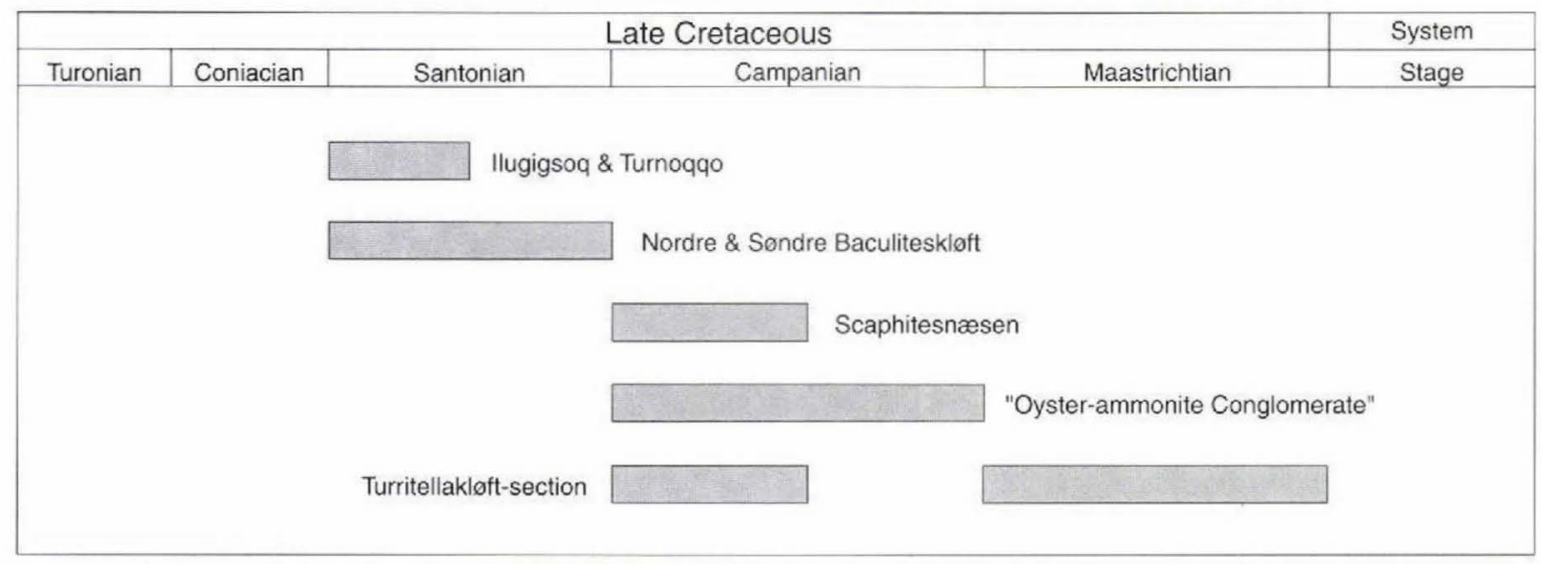

Fig. 13. Ammonite dates in central Nuussuaq obtained from Birkelund (1965).

section HNH 910718/1-3 (Enclosure 35, Birkelund, 1965, table 1). The record by Birkelund of late Campanian ammonites from 550 to $665 \mathrm{~m}$ above sea level from Brudkløft at Ikorfat, is not in conflict with the record of Coniacian or Santonian dinoflagellate cysts from the locality HNH 920824/2 Nnuu (Enclosure 37) situated at 350 to $375 \mathrm{~m}$ above sea level at Brudkløft.
The ammonites recorded from Ikorfatnæsen and Ikorfat Pass (Fig. 6) indicate a Maastrichtian age (Birkelund, 1965). The dinoflagellate cyst assemblage from the section FGC 900813/7 Nord (Enclosure 36), which is very close to these two sections, also suggests a Maastrichtian age.

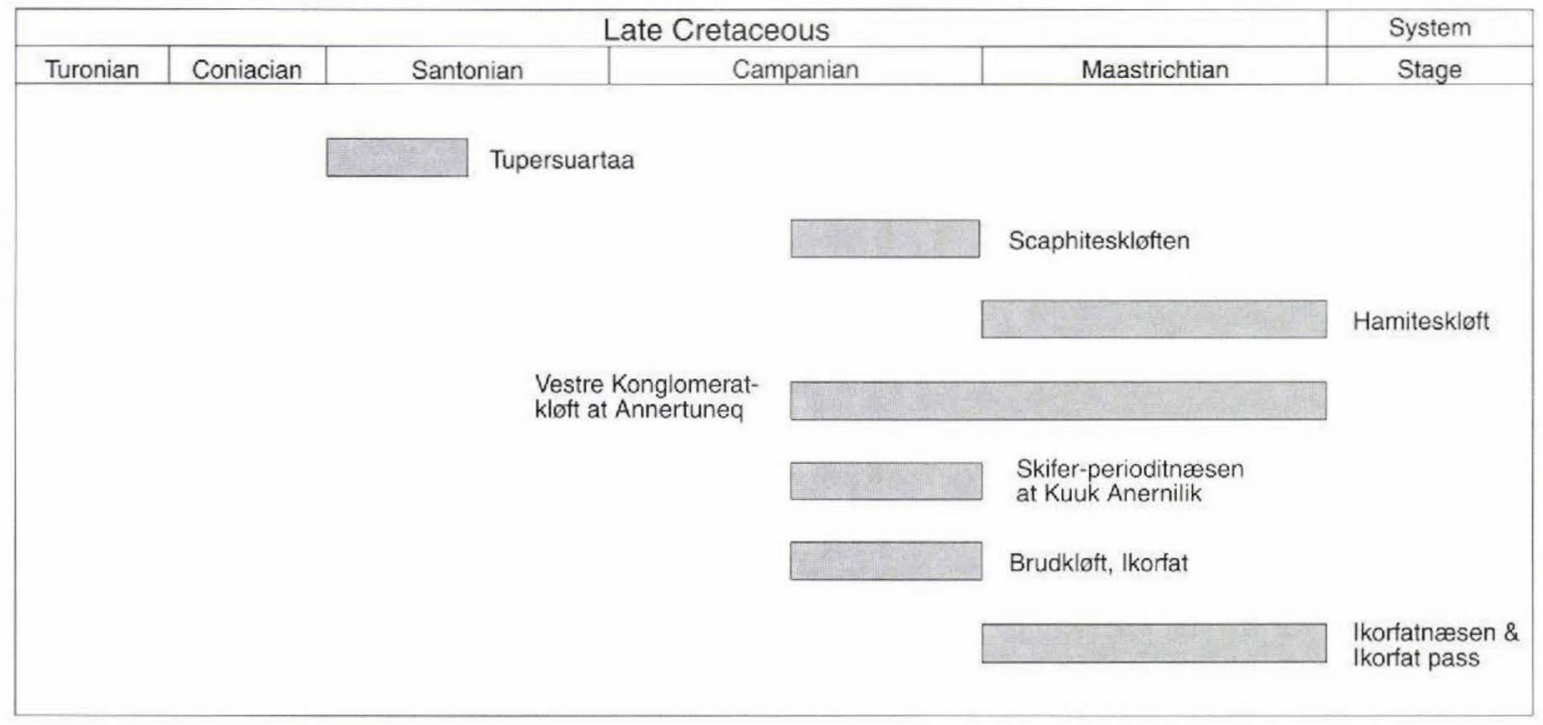

Fig. 14. Ammonite dates on the north coast of Nuussuaq obtained from Birkelund (1965). 


\section{Systematic and stratigraphic notes on selected dinoflagellate cysts}

In this paper the systematics of Lentin \& Williams (1993) are followed, except for Odontochitina striatoperforata where Singh (1971) has been followed concerning the systematic position of the species. References to species not discussed below and not listed in the References are to be found in Lentin \& Williams (1993).

The different forms recorded within the genera Arvalidinium, Chatangiella and Isabelidinium from West Greenland are described and illustrated. Additionally Cerodinium and Alterbidinium? species are commented on and described.

Division Dinoflagellata (Butschli, 1885) Fensome et al., 1993

Class Dinophyceae Pascher, 1914

Subclass Peridiniphycidae Fensome et al., 1993

Genus Alterbidinium Lentin \& Williams, 1985; emend. Khowaja-Ateequzzaman $e t$ al. 1991

\section{Alterbidinium? ulloriaq sp. nov.}

Plate 14, Figs 4-12

Origin of name. Ulloriaq; Greenlandic: star

\section{Description}

Cyst type. Circumcavate to cornucavate.

Shape. Star-like; dorso-ventrally compressed elongate pericyst with 3 horns and an extended cingulum. The shape of the endocyst is ellipsoidal to spherical, and equatorially centred. The apical horn is broad based, elongate and often broken distally, as illustrated on the holotype. The two; more or less equal antapical horns are also relatively broad based, elongate, with a blunt to pointed tip. The angle between the base of the antapical horns is usually $90^{\circ}$ or more. The lateral extension of cingulum are short $(4-10 \mu)$, with weak indented termination.

Wall relationship. The cyst is composed of a smooth to scattered granulate pericyst and endocyst. Both pericyst and endocyst are rather thin-walled and almost hyaline.

Tabulation. Paratabulation is indicated by the archeopyle and the pronounced cingulum. Granulae on the surface of the pericyst occasionally occur in rows indicating a peridinioid tabulation pattern and defining the cingulum. Archeopyle. Periarcheopyle, intercalary (2a) steno- to isodeltaform, operculum free. The form of the endoarcheopyle seems to be broader and not as elongate as the periarcheopyle, the exact form is difficult to distinguish (Plate 14, Figs 7, 12), the endoarcheopyle is most likely of type $\mathrm{I}$.

Holotype. Plate 14 Fig. 4 MGUH 23927 from GGU 408887-4, 41.0-93.0, Z411.

Type locality. Sample GGU 408887, Kangilia Formation, Annertuneq section, north coast of Nuussuaq, West Greenland (Figs 6, 7, Enclosure 33)

Dimensions. Holotype: length of pericyst $104 \mu$ (tips of apical and antapical horns broken), width of pericyst $76 \mu$, width of endocyst $58 \mu$, length of endocyst $51 \mu$.

Size. Length of pericyst 108 (120) $132 \mu$ ( 2 specimens), width of pericyst 68 (75) $84 \mu$ (10 specimens), length of endocyst 47 (53) $59 \mu$ (10 specimens), width of endocyst 57 (60) $68 \mu$ (10 specimens), length of apical horn 10 (11) $12 \mu$ (14 specimens).

\section{Discussion}

The genus. The combination of the characteristic star-like shape of the cyst and a $2 \mathrm{a}$ archeopyle may indicate that this new species represents a new genus. The species has questionably been placed in the genus Alterbidinium due to the presence of a $2 \mathrm{a}$ hexa periarcheopyle of steno- to iso-deltaform type. This periarcheopyle shape is one of the characteristics for the genus Alterbidinium (KhowajaAteequzzaman et al., 1991). The shape of the periarcheopyle in the new species $A$. ? ulloriaq may suggest a placement in the genera Cerodinium or Deflandrea; the two genera have an iso-deltaform $(C$.) or a lati-deltaform $(D)$. periarcheopyle (Lentin \& Williams, 1987). However the presence of the distinct lateral extension of the cingulum differentiates the new species from previously described species of the genera Cerodinium and Deflandrea. The distinctive outline of A.? ulloriaq is similar to the outline of some Muderongia species, which differ by having an apical archeopyle. The outline of the new species also has some similarities with the genus Rhombodinium, however Rhombodinium differs by its quadraform archeopyle and by its very reduced or vestigial right antapical horn. 
The species. Alterbidinium? ulloriaq sp. nov. has almost the same distinctive outline of the pericyst and almost the same periarcheopyle form as described for Deflandrea pentaradiata (now Alterbidinium? pentaradiatum pentaradiatum) by Cookson \& Eisenack (1965). However A.? p. pentaradiatum differs by the shape of the endocyst which is roughly oval in outline or tends to follow the outline of the pericyst, by the surface of the periphragm which is smooth or with fine longitudional striae, especially in the vicinity of the cingulum, by having almost parallel antapical horns and by the size: length of pericyst 159-171 $\mu$, width of pericyst $116-130 \mu$, length of endocyst 76-97 $\mu$, width of endocyst 82-96 $\mu$. Lentin \& Williams (1976, p. 49) questionably included the species in the genus Alterbia (now Alterbidinium) and mentioned that "the distinctive outline of the pericyst suggests it may be better placed in the genus Rhombodinium; however, the distinctively hexa archeopyle excludes it from that genus".

The questionable placement of the two species with pentaradiate shape in the genus Alterbidinium, may advocate the establishment of a new genus. However the author has not examined the type specimen of Alterbidinium? pentaradiatum pentaradiatum and the available specimens (10) of Alterbidinium? ulloriaq are considered too few to erect a new genus.

Occurrence. Alterbidinium? ulloriaq sp. nov, has been recorded from the lowermost Paleocene sample only, at the Annertuneq section on the north coast of Nuussuaq (Enclosure 33). Alterbidinium? pentaradiatum pentaradiatum was described from the Paleocene in Victoria in Australia by Cookson \& Eisenack (1965), which may suggest that the distinctive outline was developed in Paleocene time.

\section{Genus Arvalidinium Lentin \& Vozzhennikova, 1990}

\section{Arvalidinium scheii (Manum, 1963) Lentin \& Vozzhennikova, 1990}

Plate 1, Figs 1-3

Remarks. The form and tabulation pattern observed on the $A$. scheii specimens from West Greenland are similar to that described by Manum (1963) for the type material, but the length of the cyst $(65-80 \mu)$ is less than the type material $(82-116 \mu)$.

Occurrence. Arvalidinium scheii is common in a rather narrow range in West Greenland situated at a level below in situ ammonites of early Coniacian age. Manum (1963) and Manum \& Cookson (1964) suggested that their A. scheii specimens came from the upper Albian to lower Cenomanian Hassel Formation on Graham Island, arctic Canada, but Felix \& Burbridge (1976) considered that the samples more likely represented the Kanguk Formation of late Cenomanian (or Turonian) to early Campanian age. Núñez-Betelu (1994) described some forms which look like A. scheii from a narrow level in the Kanguk Formation at Axel Heiberg Island. The level was dated late Coniacian by the presence of the ammonite Scaphites depressus (Hills et al., 1994).

Genus Cerodinium Vozzhennikova, 1963; emend. Lentin \& Williams, 1987

\section{Cerodinium diebelii (Alberti, 1959b) Lentin \& Williams, 1987}

Plate 13, Figs 1-3

Remarks. Lentin \& Vozzhennikova (1990) mention in their discussion of Cerodinium leptodermum that the species is often confused with $C$. diebelii, and that the specimens illustrated as $C$. diebelii from the Maastrichtian at the Horton River section, northern Canada by McIntyre (1975) are C. leptodermum. Lentin \& Vozzhennikova (1990) mention that in C. diebelii the endocyst is more circular so that the body of the cyst between the apical and antapical horns is shorter than on C. leptodermum which has a well developed antapical pericoel that occurs below the endocyst and above the antapical horns. The author does not find it easy to distinguish the two species on these criteria. One of the $C$. diebelii specimens illustrated by Alberti (1959, pl. 9, fig 19) and perhaps also the holotype (Alberti, 1959b, pl. 9, fig. 18) appear to have a well developed antapical pericoel. In contrast some of the illustrations of C. leptodermum (Vozzhennikova, 1967, pl. 118, figs 3, 5, 7, 8, 10, pl. 119 figs 2-3) appear to have a narrow antapical pericoel.

The specimens recorded as $C$. diebelii here are forms with an oval to elongate endocyst and with a narrow or almost no antapical pericoel.

Occurrence. Cerodinium diebelii has been recorded from early Maastrichtian to late Paleocene in West Greenland. Alberti (1959) described C. diebelii from the late Senonian to the Paleocene in Germany and Kirsch (1991) and Marheinecke (1992) reported the species from early and late Maastrichtian in Germany. Costa \& Davey (1992) and Powell (1992) reported a late Campanian to late Paleocene range from the North Sea area and Williams et 
al. (1993) reported a late Santonian to Paleocene range from the northern hemisphere. Lentin \& Vozzhennikova $(1990$, p. 37) proposed that $C$. diebelii is represented in the Williams flora province whereas $C$. leptodermum is present in the McIntyre flora.

\section{Cerodinium sp. cf. C. diebelii (Alberti, 1959b) Lentin \& Williams, 1987}

Plate 13, Figs 4-6

Remarks. Cerodinium sp. cf. C. diebelii represents irregular forms that differ from $C$. diebelii sensu stricto by having longer antapical horns and by its round endocyst (Plate 13 Fig. 4) or by its very antapical extended endocyst (Plate 13 Fig. 6).

Occurrence. In West Greenland $C$. sp. cf. $C$. diebelii occurs only in a very narrow stratigraphic interval in the early Maastrichtian where it occurs together with C. diebelii.

Genus Chatangiella Vozzhennikova, 1967; emend. Lentin \& Williams, 1976

\section{Chatangiella bondarenkoi \\ (Vozzhennikova, 1967) Lentin \& \\ Williams, 1976; emend Lentin \& Vozzhennikova, 1990}

Plate 10, Figs 1-5

Remarks. The specimens observed from West Greenland are distinguished from the other Chatangiella species in this study by the large overall size $(100-150 \mu)$. The form is characterised by an elongate bicavate body with weakly developed apical shoulders and a iso-omegaform archeopyle. The granulae on the almost round endocyst appear to increase at the apical and antapical margins. The specimens seen are, except for being slightly shorter, similar to the type material described by Vozzhennikova (1967) and Lentin \& Vozzhennikova (1990). The small process on the top of the apical horn, mentioned in Vozzhennikova's (1967) original description, has been observed on one specimen (Plate 10, Fig. 5) from West Greenland.

Occurrence. Chatangiella bondarenkoi is not very common in West Greenland, where it has been recorded only from the early or 'middle' Campanian in central Nuus- suaq. Lentin \& Vozzhennikova (1990) recorded the species from Santonian of Western Siberia and Santonian to Campanian of arctic Canada.

\section{Chatangiella ditissima (McIntyre, 1975) Lentin \& Williams, 1976}

Plate 10, Figs 6-7

Remarks. The specimens observed from West Greenland are very similar to the forms, described by McIntyre (1975), which are characterised by a bicavate cyst with a broad-based apical horn, cingulum divided into ridges with arcs of intratabular pustules, endocyst with folded apical and antapical ends and a relatively large rounded intercalary eury-omegaform archeopyle.

Occurrence. Chatangiella ditissima sensu stricto is not very commom in West Greenland where it has been recorded from ?early or late Santonian to early Campanian sediments. McIntyre (1975) described a continuous range for the species from Santonian to 'middle' Campanian and sporadic occurrences in late Campanian and early Maastrichtian in the Horton River section, northern Canada. Ioannides (1986) recorded the species from his Santonian-Campanian palynological interval I on Bylot Island, arctic Canada. Costa \& Davey (1992) reported an early Turonian to late Campanian range from the North Sea area and Williams et al. (1993) reported a Santonian to early Campanian range from the northern hemisphere.

\section{Chatangiella sp. cf. C. ditissima (McIntyre, 1975) Lentin \& Williams, 1976}

Plate 1, Figs 11-12

Remarks. The specimens here described as $C$. sp. cf. $C$. ditissima differ from $C$. ditissima sensu stricto by having a shorter (10-15 $\mu$ ) blunt-ended, broad-based apical horn compared to the length (15-25 $\mu$ ) of the apical horn on the type material of $C$. ditissima. Chatangiella sp. cf. C. ditissima is also distinguished from $C$. ditissima by the shape of the cingulum, which is seldom divided into paraplate related pieces, and by the shape of its apical shoulders which in general are more pronounced.

Occurrence. In West Greenland $C$. sp. cf. $C$. ditissima is quite common in the Coniacian to late Santonian and in the late Campanian and it appears to range up to the 'earliest' Maastrichtian. 
Chatangiella granulifera (Manum, 1963) Lentin \& Williams, 1976

Plate 1, Figs 4-7

Remarks. Specimens from West Greenland described as C. granulifera have granules on the epicyst. The endocyst is round or sometimes has folded apical and antapical ends. Most of the cysts have rounded apical shoulders and a rather narrow apical horn with slightly concave sides as Manum (1963) mentioned in his description of the type material, but forms with angular apical shoulders with a flat upper limit and a broad apical horn with a triangular outline are also recorded. The more angular forms are very similar to the species $C$. verrucosa except for the absence of a warty ormamentation on the pericyst.

Occurrence. Chatangiella granulifera is common in West Greenland where it has been recorded from Coniacian or early Santonian to early or ?late Campanian. Specimens referred to $C$. sp. aff. $C$. granulifera are common in a single sample (366589, Enclosure 33) in the early Maastrichtian at Annertuneq. This form is suggested as reworked due to its rather dark brown colour and its very restricted occurrence. Manum (1963) described C. granulifera from the Turonian to Campanian Kanguk Formation on Graham Island, arctic Canada. McIntyre (1975) reported a Santonian to 'middle' Maastrichtian range for the species at Horton River, northern Canada. Ioannides (1986) recorded the species from the lower part of his Santonian-Campanian palynological interval I and Ia on Bylot Island, arctic Canada. Schiøler (1992) reported C. granulifera from the Lower to 'mid'-Coniacian on the Danish island of Bornholm and Costa \& Davey (1992) reported an early Turonian to late Campanian range from the North Sea area.

\section{Chatangiella sp. cf. C. hexacalpis Harker \& Sarjeant in Harker et al. 1990}

Plate 10, Figs 11-12

Remarks. The overall form of specimens descibed as C. sp. cf. C. hexacalpis from West Greenland is very similar to the type material described by Harker \& Sarjeant (1990). However C. sp. cf. C. hexacalpis differs by having a cingulum divided into 5 to 7 pieces and by the shape of its left antapical horn which is reduced to a bulge. The archeopyle on $C$. sp. cf. $C$. hexacalpis is similar to that on the type material of $C$. hexacalpis, but the specimens described by Harker \& Sarjeant are larger.

Occurrence. Chatangiella sp. cf. C. hexacalpis is rare in West Greenland, where it has been recorded from the early to late Santonian in central Nuussuaq. Harker \& Sarjeant (1990) described the species from late Campanian in the Western Interior, North America.

\section{Chatangiella mcintyrei $\mathrm{sp}$. nov.}

Plate 2, Figs 4-9

Origin of name. After David J. McIntyre, who did a great pioneer work in 1975 when he described the morphologic changes in Deflandrea from the Campanian of the Horton River section, northern Canada.

\section{Description}

Cyst type. Circumcavate, peridinioid

Shape. Dorso-ventrally compressed cyst, elongate, almost box-shaped. The width of the cyst is almost the same from the broad apical shoulders to the antapical 'horns', except from the areas at the apical and antapical ends of the endocyst, where the periphragm has slightly concave sides. The epicyst and hypocyst are almost the same length. The apical horn is broad-based, short and blunt, with slightly concave sides. The left antapical horn is short and pointed, the right antapical horn is only represented by a bulge.

Wall relationship. The cyst is composed of a smooth to scattered granulate box shaped pericyst and a spherical to slightly apical-antapical compressed endocyst, equatorially centred. Both pericyst and endocyst are rather thinwalled and almost hyaline, which occasionally makes it difficult to distinguish the outline of the endocyst.

Tabulation. Paratabulation is indicated only by the archeopyle and the cingulum, which on both anterior and posterior margins is bordered by discontinuous ridges with tubercles. Five pairs of ridges have been observed; but more likely 7 pieces of anterior ridges and 5 pieces of postcingular ridges should be expected, as in most Chatangiella species. A large wide sulcus is present on the ventral surface.

Archeopyle. Intercalary (2a) rounded iso-omegaform archeopyle. Operculum often attached at posterior margin. One example of a 3I endoarcheopyle with the three plates attached along their posterior margins has been observed (Plate 2, Fig. 7). The complete archeopyle formula for the species is of type I/I or seldom type I/3I.

Holotype. Plate 2, Fig. 4, MGUH 23784 from GGU 400711-10-7, 35.3-96.6, W35 2. 
Type locality. Core hole GGU 400711, Enclosure 10, Svartenhuk, West Greenland (Fig. 3).

Dimensions. Holotype: length of pericyst $101 \mu$, width of pericyst $70 \mu$, length of endocyst $52 \mu$, width of endocyst $56 \mu$, length of apical horn $11 \mu$.

Size range. Length of pericyst 87 (95) $108 \mu$, width of pericyst 53 (61) $70 \mu$, length of endocyst 36 (45) $52 \mu$, width of endocyst 40 (47) $56 \mu$, (15 specimens) length of apical horn 10 (11) $12 \mu$ (14 specimens).

Discussion. The pericyst size and shape in the new species Chatangiella mcintyrei are quite similar to that of C. granulifera and C. verrucosa, from which it is easily distinguished by being circumcavate. The box-shaped outline of $C$. mcintyrei distinguishes it from the rhombicshaped, circumcavate species $C$. spectabilis.

Occurrence. The species has been recorded from the Coniacian Arvalidium cheii and Laciniadinium arcticum intervals on Svartenhuk (Enclosures 1, 8,10).

\section{Chatangiella sp. cf. C. madura Lentin \& Williams, 1976, nom. subst. pro Chatangiella manumii (Cookson \& Eisenack, 1970a)}

Plate 2, Figs 1-3

Remarks. The specimens from West Greenland often have very pronounced apical schoulders and a broad-based short apical horn. The periphragm is ornamented by grana or baculae, the ornament is most pronounced equatorially, but paratabulation is very seldom distinguished. The endocyst often has folded apical and antapical ends. The intercalary archeopyle is rounded iso-omegaform to ?iso-thetaform. The holotype of Chatangiella madura (Cookson \& Eisenack, 1970) differs from the present material by having a more prominent ornamented periphragm reflecting the paratabulation and a round to spherical endocyst.

Cookson \& Eisenack (1970) mentioned that the shape and size of $C$. madura is close to that of $C$. tripartita, but that the paratabulation for the pre- and postcingular plate series on C. madura distinguishes the species from C. tripartita.

Ionannides (1986) mentioned in his remarks on the C. madura specimens recorded from Bylot Island, arctic Canada, that $C$. madura and $C$. tripartita in gross morphology are very similar and they perhaps form part of the intraspecific variability of a single species.
Occurrence. In West Greenland Chatangiella sp. cf. C. madura has been recorded only from the Coniacian C. sp. cf. C. madura and Spinidinium echinoideum intervals from Svartenhuk Halvø. Cookson \& Eisenack (1970) described $C$. madura from the Senonian of Western Australia. Ioannides (1986) recorded the species from the lower part of his Santonian-Campanian palynological interval I on Bylot Island, arctic Canada. Harker et al. (1990) recorded C. madura from a very narrow interval in the 'latest' Campanian in the Western Interior of the U.S.A.. They recorded the almost identical species C. tripartita from the 'latest' Santonian to 'earliest' Maastrichtian (which included the majority of their studied stratigraphical interval). Kirsch (1991) reported C. madu$r a$ from the lower part of his Coniacian/Santonian Raetiaedinium truncigerum Zone and from his Campanian Areoligera coronata Zone in Oberbayern, Germany. Núñez-Betelu (1994) recorded C. madura from his Zone 2 (late Turonian to late Coniacian) and his Zone 3 (late Coniacian to early Campanian) at Glacier Fiord, arctic Canada. Chatangiella tripartita was described by Cookson \& Eisenack (1960) from probable late Turonian to middle Senonian of Australia. Aurisano (1989) recorded an early Santonian to early late Campanian range for C. tripartita in the New Jersey Atlantic Coastal Plains, U.S.A. Schiøler (1992) reported C. tripartita from the early to 'mid'-Coniacian on the Danish island of Bornholm. Costa \& Davey (1992) reported the C. tripartitavictoriensis complex from late Cenomanian to early Maastrichtian in the North Sea region. Marheinecke (1992) recorded the species as ranging up to the late part of the early Maastrichtian in Germany. Helby et al. (1987) reported C. tripartita from early Santonian (consistent) to middle and late Santonian (inconsistent).

\section{Chatangiella sp. aff. C. spectabilis (Alberti 1959b) Lentin \& Williams, 1976}

Plate 2, Figs 10-12

Remarks. The specimens from West Greeenland described as $C$. aff. $C$. spectabilis are thin-walled, weakly granulate, almost hyaline, circumcavate cysts with fragmented cingulum ridges, all features of $C$. spectabilis. However C. sp. aff. C. spectabilis differs from $C$. spectabilis in having a very small right antapical horn and a less elongate and more spherical shape pericyst compared to the rhombic shape pericyst of the type material of C. spectabilis.

Occurrence. Chatangiella sp. aff. C. spectabilis is recorded from almost all the studied Coniacian to early Santonian sections (Enclosures 1-13) on Svatenhuk Halvø, 
West Greenland. Alberti (1959) described C. spectabilis from the late Senonian in Germany. McIntyre (1975) recorded a Santonian to 'middle' Campanian range for the species in the Horton River section, northern Canada. Ioannides (1986) recorded the species from the lower part of his Santonian-Campanian palynological interval I and Ia on Bylot Island, arctic Canada. Kirsch (1991) recorded C. spectabilis from the uppermost part of his Raetiaedinium truncigerum Zone and from his Odontochitina costata Zone both of Coniacian or Santonian age, Oberbayern, Germany. Costa \& Davey (1992) reported a rather limited (early Campanian to earliest late Maastrichtian) stratigraphic range in the North Sea area.

\section{Chatangiella verrucosa (Manum, 1963) Lentin \& Williams, 1976}

Plate 1, Figs 8-10

Remarks. The specimens recorded from West Greenland have the same angular apical shoulders and verrucae closely spaced in the equatorial area as described by Manum (1963) for the type material of $C$. verrucosa. Manum mentioned that examples with verrucae all over the cyst do occur; a single specimen densely covered with verrucae also has been observed from West Greenland (Plate 1, Fig. 9).

Occurrence. Chatangiella verrucosa is uncommon in West Greenland, where it has been recorded from the Coniacian to early Santonian on Svartenhuk Halvø. Manum (1963) described $C$. verrucosa from the Turonian to Campanian Kanguk Formation on Graham Island, arctic Canada. Ioannides (1986) recorded the species from his Santonian-Campanian palynological interval I and Ia on Bylot Island, arctic Canada. Prössl (1990) recorded a first occurrence in the late Turonian in Germany. Williams et al. (1993) reported a Santonian to late Campanian range from the northern hemisphere.

\section{Genus Isabelidinium Lentin \& Williams, $1977 \mathrm{a}$}

\section{Isabelidinium acuminatum (Cookson \& Eisenack, 1958) Stover \& Evitt, 1978}

Plate 11, Figs 1-6

Remarks. The specimens from West Greenland included in I. acuminatum are in general similar to the type material described by Cookson \& Eisenack (1958). The specimens are pronounced circumcavate cysts with a small acuminate apical horn and a pointed left antapical horn. A cingulum has been recognized on most of the specimens. Both peri- and endocyst are hyaline with a psilate to scabrate surface. The form of the endocyst is spherical on all the observed specimens as illustrated by Cookson \& Eisenack (1958, plate 4, fig. 8) and by Manum \& Cookson (1964, plate 1, fig. 4), and not slightly pointed apicaly as illustrated by Cookson and Eisenack (1958, plate 4, figs 5-7). The forms with a granular endocyst as illustrated by McIntyre (1975, plate 2, figs $11 \& 13$ ) are not recorded from West Greenland.

Occurrence. Isabelidinium acuminatum is recorded only from the early to 'middle' Campanian on central Nuussuaq in West Greenland. Cookson \& Eisenack (1958) described the species from Cenomanian to early Turonian in Australia. Manum \& Cookson (1964) recorded the species from the Kanguk Formation, Graham Island, arctic Canada which, according to Felix \& Burbridge (1976), is of late Cenomanian to early Campanian age. McIntyre (1975) recorded an early to 'middle' Campanian age in northern Canada. Williams \& Brideaux (1975) recorded the species from Coniacian to Maastrichtian from Grand Banks, offshore eastern Canada. Ioannides (1986) recorded the species from the lower part of his Santonian-Campanian palynological intervals I and Ia, from his possible Maastrichtian interval II, and from the lower part of his Maastrichtian interval IIIa on Bylot Island, arctic Canada. Harker et al. (1990) recorded I. acuminatum from the late Sanonian to the early Campanian in Western Interior, North America and Costa \& Davey (1992) mentioned that $I$. acuminatum first occurs, or first become consistent in the early Campanian.

\section{Isabelidinium sp. aff. I. acuminatum (Cookson \& Eisenack, 1958) Stover \& Evitt, 1978}

Plate 3, Figs 4-6

Remarks. The specimens from West Greenland, described as $I$. sp. aff. $I$. acuminatum, are generally similar to I. acuminatum, but differ by having a larger endocyst with a granulate ornamentation at the rim and psilate to shagreenate ornamentation on the main part of the dorsal and ventral surfaces. The apical horn is more pronounced and slightly longer on the $I$. sp. aff. I. acuminatum specimens recorded from West Greenland. The archeopyle on the pericyst is intercalary steno- to iso-thetaform, which differs from the more rounded archeopyle observed on I. acuminatum.

Occurrence. A few specimens of $I$. sp. aff. I. acuminatum 
have been recorded only from the very narrow late Santonian or early Campanian Dinogymnium sp. cf. $D$. sibiricum interval on Svartenhuk Halvø, West Greenland.

\section{'Isabelidinium sp. aff. I. bujakii' Marheinecke, 1990}

Plate 15, Figs 4-5

Remarks. According to Lentin \& Williams (1993) the species name is not validly published since the lodgement of the holotype has not been specified by Marheinecke.

The specimens described as 'I. sp. aff. I. bujakii', from West Greenland, are bicavate cysts with a circular to apical or antapical compressed endocyst, with an equatorially expanded pericyst. The shape of the epicyst is clearly concave between the apical part of the endocyst and the lower part of the pronounced angular apical shoulders. The broad-based blunt apical horn has slightly concave sides. The archeopyle is intercalary, type $2 \mathrm{a} / 2 \mathrm{a}$, stenotetraform. 'Isabelidinium sp. aff. I. bujakii' differs from the material of Marheinecke (1992) by having an apical or antapical compressed endocyst, and by the shape of the apical shoulders which make the epicyst shape more complex than the quasi triangular epicyst described by Marheinecke (1992).

Both 'I. sp. aff. I. bujakii' and 'I. bujakii' differ from I. bakeri and I. belfastense which are described as circumcavate cysts with very apical shoulders.

Occurrence. In West Greenland 'I. sp. aff. I. bujakii' is recorded from ?'latest' Campanian to late Maastrichtian on the north coast of Nuussuaq. Marheinecke recorded 'I. bujakii' from the late early Maastrichtian in Germany.

\section{Isabelidinium cooksoniae (Alberti, 1959b) Lentin \& Williams, 1977a}

Plate 15, Figs 6-10

Remarks. The variation in specimens included in the species $I$. cooksoniae is similar to the variation illustrated by Alberti (1959). Howewer specimens with a reduced apical horn and a shorter left antapical horn are dominant in West Greenland.

Occurrence. The species is recorded from Coniacian or Santonian to late Campanian in West Greenland, where it is very common in the late Campanian deposits at Annertuneq on the north coast of Nuussuaq.

Alberti (1959) described $I$. cooksoniae from the late Senonian in Germany. Ioannides (1986) recorded the species from the lower part of his Santonian-Campanian palynological interval Ia, from his possible Maastrichtian interval II and from the lower part of his Maastrichtian interval III on Bylot Island, arctic Canada. Costa \& Davey (1992) reported I. cooksoniae from middle Turonian to latest Maastrichtian in the North Sea area.

\section{Isabelidinium microarmum (McIntyre, 1975) Lentin \& Williams, 1977a}

Plate 10, Figs 9-10

Remarks. The specimens of $I$. microarmum recorded from the early to 'middle' Campanian in West Greenland are similar to the type material described by McIntyre (1975).

Occurrence. McIntyre (1975) recorded an early Campanian to 'middle' Maastrichtian range for the species in the Horton River section in northern Canada. Ioannides (1986) recorded the species from the lower part of his possible Maaastrichtian palynological interval II on Bylot Island, arctic Canada. Costa \& Davey (1992) mention that $I$. microarmum does not seem to have persisted beyond the end of the Campanian in the Shetland Group, North Sea.

\section{Isabelidinium svartenhukense sp. nov.}

Plate 3, Figs 7-12

Origin of name. After Svartenhuk Halvø, the area in West Greenland from which this species is described.

\section{Description}

Cyst type. Hypocavate-circumcavate, peridinioid

Shape. Dorso-ventrally compressed cyst, with an almost ovoidal to elongate quasi-pentagonal outline. The apical horn on the ovoidal specimens is reduced to a small bulge and the left antapical horn is very short whereas the right antapical horn is only a bulge. Specimens with a more elongate outline have a small blunt apical horn and a short left antapical horn. The right antapical horn is very short or more commonly appears as a bulge. Both forms have a spherical endocyst.

Wall relationship. The cyst is composed of a smooth to scabrate, hyaline pericyst and a hyaline endocyst. The endophragm approaches the periphragm at the equator or just above and the two wall layers are parallel, with a very narrow epipericoel $(1-3 \mu)$, up to the apical part of the cyst where the epipericoel can extend up to $10 \mu$ forming an apical horn or bulge. The hypopericoel on the ovoidal forms is smaller than on the more elongate forms. 
Tabulation. Paratabulation is only indicated by the archeopyle and the cingulum, when present. Cingulum is most common on the elongate forms, where its anterior and posterior margins are bordered by ridges with small granulae. On the ovoidal specimens a very weak tabulation pattern and cingulum outline is occasionally indicated by rows of granulae.

Archeopyle. Intercalary (2a) thetaform archeopyle. Operculum often attached at posterior margin. It has not been possible to observe the endoarcheopyle.

Holotype. Plate 3, Fig. 7, MGUH 23799 from GGU 400712-26-4, 26.6-97.0, V26 2.

Paratype. Plate 3, Fig. 11, MGUH 23803 from GGU 400712-15-4, 35.5-102.1, P35 4.

Type locality. Core hole GGU 400712, Enclosure 8, Svartenhuk Halvø, West Greenland (Fig. 3)

Dimensions. Holotype: length of pericyst $65 \mu$, width of pericyst $58 \mu$, length of endocyst $45 \mu$. Paratype: length of pericyst $93 \mu$, width of pericyst $65 \mu$, length of endocyst $54 \mu$

Size range. Ovoidal forms (10 specimens) length of pericyst 60 (71) $83 \mu$, width of pericyst 45 (55) $63 \mu$, length of epicyst 45 (52) $61 \mu$. Elongate forms (14 specimens) length of pericyst 74 (82) $93 \mu$, width of pericyst 43 (56) $65 \mu$, length of epicyst $43(52) 60 \mu$.

Discussion. The shape of the pericyst, endocyst and very narrow epipericoel distinguish the new species Isabelidinium svartenhukense from most other Isabelidinium species. I. svartenhukense is very similar in shape to I. variabile Marshall (1988), especially the informally described subspecies A and D (Marshall, 1988, p. 207, 211). However $I$. variabile differs by having a periphragm with closely spaced perforations and a scabrate, granulate or verrucate endophragm. The species Eurydinium glomeratum (Davey, 1970) Stover \& Evitt 1978, is distinguished from $I$. svartenhukense by having a much smaller hypopericoel and by having an endocyst that is in contact with the periphragm except in the apical and antapical regions.

Occurrence. The species has been recorded from the Coniacian and early Santonian Arvalidium scheii, Laciniadinium arcticum and Heterosphaeridium difficile intervals on Svartenhuk (Enclosures 1, 8, 10,11). The ovoidal form is most common in the $A$. scheii interval, whereas the elongate form first occurs in the top of the $A$. scheii interval. The somewhat similar species I. variabile has been described from the Santonian in southern Australia by Marshall (1988) and later recorded from the late Santonian to the late Campanian in the same area (Marshall, 1990).

\section{Isabelidinium sp. $7 \mathrm{HNH}$}

Plate 3, Figs 1-3

Remarks. The specimens described as Isabelidinium sp. 7 $\mathrm{HNH}$ are relatively large bicavate cysts, with a large spherical endocyst. The size range is: length 72 (85) $95 \mu$, width 50 (60) $65 \mu$, length of epicyst 47 (54) $58 \mu$ (seven specimens). The apical shoulders are broad. The apical horn is small and blunt, a left antapical horn can be distinguished, but a right antapical horn is usually not seen. The periphragm is psilate to scabrate and hyaline, the endophragm is light yellow. Two very faint rows of granulae occasionally indicate a cingulum. The archeopyle on the pericyst is intercalary (2a) broad euryomegaform. Operculum often attached at its posterior margin. Examples of a 3I endoarcheopyle with the three plates attached along their posterior margins have been observed. The archeopyle formula is I/3I.

The form has been placed in the genus Isabelidinium due to the absence of a clear cingulum. The only other species $I$. sp. 7 can be compared with is Isabelidinium korojense, but $I$. sp 7 differs by the shape of its apical shoulders, the shape of its archeopyle and the outline of its endocyst, which on $I$. korojense is folded at its apical and antapical ends.

Occurrence. Isabelidinium sp. $7 \mathrm{HNH}$ is recorded from the Coniacian Chatangiella sp. cf. C. madura and Spinidinium echinoideum intervals on Svartenhuk Halvø, West Greenland. The stratigraphic range is similar to the range of $C$. sp. cf. C. madura.

\section{Acknowledgements}

The author's work was financed by the Danish Ministry of Energy as part of the 'Kridtsedimenter, Vestgronland' (Grant No. EFP 1313/91 0014).

John Boserup and Flemming Getreuer Christiansen, GGU (Geological Survey of Greenland) and Helle Midtgaard and Christian J. Bjerrum, GI (Geological Institute, University of Copenhagen) are thanked for their valuable help and company during the sampling and fieldwork.

Special thanks go to David J. McIntyre, Arthur R. Sweet GSC (Geological Survey of Canada) Calgary, Canada, Stefan Piasecki, Gregers Dam, Martin Sønderholm, T. C. R. Pulvertaft (GGU) and Gunver K. Pedersen (GI) for many discussions during the work.

The author is grateful to the staff at GGU of whom Stuart Watt did the editing, Kim Villadsen and Henrik Lund prepared the samples, Jette Halskov and Carsten Thuesen produced the figures. 
I am grateful to Lucy I. Costa (Simon Petroleum Technology Ltd, Llandudno, United Kingdom) and David J. McIntyre (Geo- logical Survey of Canada, Calgary, Canada) for critically reviewing the manuscript and suggesting improvements.

\section{References}

Alberti, G. 1959: Zur Kenntnis der Gattung Deflandrea Eisenack (Dinoflag.) in der Kreide und im Alttertiär Nord- und Mitteldeutschlands. Mitt. Geol. Staatsinst. Hamburg 28, 93-105.

Askin, R. A. 1988: Campanian to Paleocene palynological succession of Seymour and adjacent islands, northeastern Antarctic Peninsula. In Feldmann, R. M. \& Woodburne, M. O. (ed.) Geology and Paleontology of Seymour Island, Antarctic peninsula. Mem. Geol. Soc. Am. 169, 131-153.

Aurisano, R. W. 1984: Three new dinoflagellate species from the subsurface Upper Cretaceous Atlantic coastal plain of New Jersey. J. Paleont. 58, 1-8.

Aurisano, R. W. 1989: Upper Cretaceous dinoflagellate biostratigraphy of the subsurface Atlantic coastal Plain of New Jersey and Delaware, U.S.A. Palynology 13, 143-179.

Aurisano, R. \& Habib, D. 1977: Upper Cretaceous dinoflagellate zonation of the subsurface Toms River section near Toms River, New Jersey. In Swain, F. M. (ed.) Stratigraphic Micropaleontology of Atlantic Basin and Borderlands. Developments in Palaeontology and Stratigraphy 6, 369-387.

Barss, M. S., Bujak, J. P. \& Williams, G. L. 1979: Palynological zonation and correlation of sixty-seven wells, eastern Canada. Pap. Geol. Surv. Can. 78-24, 118 pp.

Benham, P. H. \& Burden, E. T. 1990: Stratigraphy of CretaceousTertiary rocks of North Bylot Trough, Bylot Island, N.W.T. Pap. Geol. Surv. Can. 90-1D, 179-185.

Benson, D. G. 1976: Dinoflagellate taxonomy and biostratigraphy at the Cretaceous-Tertiary boundary, Round Bay, Maryland. In Skinner, H. C. (ed.) Tulane Stud. Geol. Paleont. 12, 169-234.

Birkelund, T. 1965: Ammonites from the Upper Cretaceous of West Greenland. Bull. Grønlands geol. Unders. 56 (also Meddr Grønland 179, 7), 192 pp.

Bujak, J. P. \& Williams, G. L. 1978: Cretaceous palynostratigraphy of offshore south-eastern Canada. Bull. Geol. Surv. Can. 297, 19 pp.

Burden, E. T. \& Langille, A. B. 1990: Stratigraphy and sedimentology of Cretaceous and Paleocene strata in half-grabens on the southeast coast of Baffin Island, Northwest Territories. Bull. Can. Petrol. Geol. 38, 185-195.

Burden, E. T. \& Langille, A. B. 1991: Palynology of Cretaceous and Tertiary strata, northeast Baffin Island, Northwest Territories, Canada: implications for the history of rifting in Baffin Bay. Palynology 15, 91-114.

Chalmers, J. A. 1991: New evidence on the structure of the Labrador Sea, Greenland continental margin. J. Geol. Soc., Lond., 148, 899-908.

Chalmers, J. A. \& Pulvertaft, T. C. R. 1993: The southern West Greenland continental shelf - was petroleum exploration abandoned prematurely? In Vorren, T. O. (ed.) Arctic geology and petroleum potential, 55-66. Amsterdam: Elseveir for Norwegian Petroleum Society.

Chalmers, J. A., Pulvertaft, T. C. R., Christiansen, F. G., Larsen, H. C., Laursen, K. H. \& Ottesen, T. G. 1993: The southern West Greenland continental margin: rifting history, basin development, and petroleum potential. In Spencer, A. M. (ed.) Petroleum geology of Northwest Europe. Proceedings of the 4th conference, 915-931. London: Geological Society.

Christiansen, F. G., Dam, G., McIntyre, D. J., Nøhr-Hansen, H., Pedersen, G. K. \& Sønderholm, M. 1992: Renewed petroleum geological studies onshore West Greenland. Rapp. Grønlands geol. Unders. 155, 31-35.

Christiansen, F. G. 1993: Disko Bugt Project 1992, West Greenland. Rapp. Grønlands geol. Unders. 159, 47-52.

Clarke, R. F. A. \& Verdier, J. P. 1967: An investigation of microplankton assemblages from the chalk of the Isle of Wight, England. Verh. K. ned. Akad. Wet., Afd. natuurk. (1), 24 (3), 94 pp.

Cookson, I. C. \& Eisenack, A. 1958: Microplankton from Australian and New Guinea Upper Mesozoic sediments. Proc. $R$. Soc. Victoria 70, 19-79.

Cookson, I. C. \& Eisenack, A. 1960: Microplankton from Australian Cretaceous sediments. Micropaleontology 6, 1-18.

Cookson, I. C. \& Eisenack, A. 1962: Additional microplankton from Australian Cretaceous sediments. Micropaleontology 8 , 485-507.

Cookson, I. C. \& Eisenack, A. 1965: Microplankton from the Paleocene Pebble Point Formation, south-western Victoria. Proc. R. Soc. Victoria 79, 139-146.

Cookson, I. C. \& Eisenack, A. 1970: Cretaceous microplankton from the Eucla Basin, Western Australia. Proc. R. Soc. Victoria $83,137-157$.

Costa, L. I. 1985: Dinoflagellate cysts stratigraphy in the Upper Cretaceous of the Central Graben, Norwegian North Sea. North Sea Chalk Symposium, Copenhagen 1985, Book 1, [Article 6], 9 pp.

Costa, L. I. \& Davey R. J. 1992: Dinoflagellate cysts of the Cretaceous System. In Powell, A. J. (ed.) A stratigraphic Index of Dinoflagellate Cysts, 99-131. British Micropalaeontological Society.

Croxton, C. A. 1976: Sampling of measured sections for palynological and other investigations between $69^{\circ}$ and $72^{\circ} \mathrm{N}$, central West Greenland. Rapp. Gronlands geol. Unders. 80, 36-39.

Croxton, C. A. 1978a: Report of field work undertaken between $69^{\circ}$ and $72^{\circ} \mathrm{N}$, central West Greenland in 1975 with preliminary palynological results. Open File Rep. Gronlands geol. Unders. 78/1, 88 pp.

Croxton, C. A. 1978b: Report of field work undertaken between $69^{\circ}$ and $72^{\circ} \mathrm{N}$, central West Greenland in 1977 with preliminary palynological results. Unpublished intern. GGU report, $24 \mathrm{pp}$. 
Croxton, C. A. 1980: Aquilapollenites from the late Cretaceous Paleocene (?) of central West Greenland. Rapp. Gronlands geol. Unders. 101, 5-27.

Dam, G. \& Sønderholm, M. 1994: Lowstand slope channels of the Itilli succession (Maastrichtian - Lower Paleocene), Nuussuaq, West Greenland. Sedimentary Geology 94, 49-71.

Davey, R. J. 1970: Non-Caleareous microplankton from the Cenomanian of England, northern France and North America. Part II. Bull. Brit. Mus. (Nat. Hist.) Geol. 18, 333-397.

Doerenkamp, A., Jardine, S. \& Moreau, P. 1976: Cretaceous and Tertiary palynomorph assemblages from Banks Island and adjacent areas (N.W.T.). Bull. Can. Petrol. Geol. 24, 372-417.

Ehman, D. A., Sodero, D. E. \& Wise, J. C. 1976: Report on ARCO and Chevron Groups 1975 West Greenland field party, ARCO Greenland Inc., 84 pp. [released; available in GGU].

Felix, C. J. \& Burbridge, P. P. 1976: Age of microplankton studied by Manum and Cookson from Graham and Ellef Ringnes Islands. Geoscience and Man 15, 83-86.

Foucher, J-C. 1971a: Étude micropaléontologique des silex coniaciens du puits 19 de Lens-Liévin (Pas-de-Calais). Bull. Muséum National d'Histoire Naturelle 3 (21), 157 pp.

Foucher, J-C. 1971b: Microfossiles de silex coniaciens de la falaise du Bois-de-Cise (Somme). Cahiers de Micropaléontologie 2 (8), 1-13.

Foucher, J-C. 1979: Distribution stratigraphique des kystes de dinoflagellés et des acritarches dans le crétacé supérieur du bassin de Paris et de l'Europe septentrionale. Palaeontographica B 169, 78-105.

Foucher, J-C. 1982: Les Dinokystes Cenomano-Turoniens du Saumurois et de Touraine (Bassin de Paris, France). Joint meeting of Commission Internationale de Microflore du Paléozoique and American Association of Stratigraphic Palynologists, Dublin 13-15 Septembre 1982 (Poster Session).

Foucher, J-C. 1983: Les dinokystes de craies Campano-Maastrichtiennes d'Halembaye (Belgique) et de Beutenaken (PaysBas). Inventaire et repartition stratigraphique. 8ème Symposium de l'Association des Palynologues de Langue Française Paris, 10-12 Octobre 1983. (Poster Session).

Hansen, H. J. 1970: Danian Foraminifera from Nûgssuaq, West Greenland. Bull. Grønlands geol. Unders. 93 (also Meddr Grønland 193, 2), 132 pp.

Hansen, J. M. 1976: Microplankton and sedimentological studies in the Nûgssuaq and Disko region, central West Greenland. Rapp. Grønlands geol. Unders. 80, 39-42.

Hansen, J. M., 1980: Stratigraphy and structure of the Paleocene in central West Greenland and Denmark. Unpublished lic. scient. thesis, Geological Institute, Univ. Copenhagen, $156 \mathrm{pp}$.

Hansen, J. M. \& Gudmundsson, L. 1978: A method for separation of acid insoluble microfossils from organic debris. Micropalaeontology 25, 113-117.

Haq, B. U., Hardenbol, J. \& Vail, P. R. 1987: Chronology of fluctuating sea levels since the Triassic. Science, N.Y. 235, 11561166.

Harker, S. D., Sarjeant, W. A. S., Caldwell, W. G. E. 1990: Late Cretaceous (Campanian) organic-walled microplankton from the Interior Plains of Canada, Wyoming and Texas: biostratigraphy, palaeontology and palaeoenvironmental interpretation. Palaeontographica B 219, 243 pp.
Harland, R. 1973: Dinoflagellate cysts and acritarchs from the Bearpaw Formation (Upper Campanian) of southern Alberta, Canada. Palynology 16 (4), 665-706.

Harland, R. 1977: Dinoflagellate cysts from the Bearpaw Formation (?Upper Campanian to Maastrichtian) of Montana. Palynology 20 (1), 179-193.

Hart, M. B., Weaver, P. P. E., Clements, R. G., Burnett, J. A., Tocher, B. A., Batten, D. J., Lister, J. K. \& MacLennan, A. M. 1987: The Isle of Wight. Cretaceous. In Lord, A. R. \& Brown, P. R. (ed.) Mesozoic and Cenozoic stratigraphical micropalaeontology of the Dorset coast and Isle of Wight, Southern England. Field Guide for the XXth. European Micropalaeontological Colloquium. British Micropalaeoltological Society, Guide Book 1, 88-149.

Heilmann-Clausen, C. 1985: Dinoflagellate stratigraphy of the uppermost Danian to Ypresian in the Viborg 1 borehole, central Jylland, Denmark. Geol. Surv. Denmark A 7,69 pp.

Henderson, G., Rosenkrantz, A. \& Schiener, E. J. 1976: Cretaceous-Tertiary sedimentary rocks of West Greenland. In Escher, A. \& W. S. Watt (ed.) Geology of Greenland, 341-362. Copenhagen: Geological Survey of Greenland.

Henderson, G., Schiener, E. J., Risum, J. B., Croxton, C. A. \& Anderseon, B. B. 1981: The West Greenland basin, In Kerr, J. W. \& Ferguson, A. J. (ed.) Geology of the North Atlantic borderlands. Mem. Can. Soc. Petrol. Geol. 7, 399-428.

Helby, R., Morgan, R. \& Partridge, A. D. 1987: A palynological zonation of the Australian Mesozoic. In Jell, P. A. (ed.) Studies in Australian Mesozoic palynology. Mem. Ass. Australasian Palaeontol. 4, 1-94.

Hills, L. V., Braunberger, W. F., Núñez-Betelu, L. K. \& Hall, R. L. 1994: Paleogeographic ssignificance of Scaphites depressus in the Kanguk Formation (Upper Cretaceous), Axel Heiberg Island, Canadian Arctic. Can. J. Earth Sci. 31, 733-736.

Ioannides, N. S. 1986: Dinoflagellate cysts from Upper Cretaceous - Lower Tertiary sections, Bylot and Devon Islands, Arctic Archipelago. Bull. Geol. Surv. Can. 371, 99 pp.

Ioannides, N. S. \& McIntyre, D. J. 1980: A preliminary palynological study of the Caribou Hills outcrop section along the Mackenzie River, District of Mackenzie. Pap. Geol. Surv. Can. 80-1A, 197-208.

Jarvis, I., Leary, P. N. \& Tocher, B. A. 1987: Mid-Cretaceous (Albian-Turonian) stratigraphy of Shapwick Grange Quarry, SE Devon, England. Mesozoic Res. 1, 119-134.

Jarvis, I., Carson, G. A., Cooper, M. K. E., Hart, M. B., Leary, P. N., Tocher, B. A., Horne, D. \& Rosenfeld, A. 1988: Microfossil assemblages and the Cenomanian-Turonian (late Cretaceous) oceanic anoxic event. Cretaceous Res. 9, 3-103.

Jürgensen, T. \& Mikkelsen, N. 1974: Coccoliths from volcanic sediments (Danian) in Nûgssuaq, West Greenland. Bull. geol. Soc. Denmark. 23, 225-230.

Khowaja-Ateequzzaman, G. R. \& Jain, K. P. 1991: Some observations on dinoflagellate cyst genus Alterbidinium Lentin and Williams. Palaeobotanist 39, 37-45.

Kirsch, K.-H. 1991: Dinoflagellatenzysten aus der Oberkreide des Helvetikums und Nordultrahelvetikums von Oberbayern. Münchner Geowiss. Abh. A 22, 306 pp.

Kurita, H. \& McIntyre, D. J. 1994: Dinoflagellate assemblages and depositional environments of the Campanian Bearpaw For- 
mation, Alberta. Bull. Geol. Surv. Can. 479, 67-83.

Larsen, L. M., Pedersen, A. K., Pedersen, G. K. \& Piasecki, S. 1992: Timing and duration of Early Tertiary volcanism in the North Atlantic: new evidence from West Greenland. In Storey, B. C., Alabaster, T. \& Pankhurst, R. J. (ed.) Magmatism and the causes of continental break-up. Spec. Publ. Geol. Soc., Lond. 68, 321-333.

Lentin, J. K. \& Vozzhennikova, T. F. 1990: Fossil dinoflagellates from the Jurassic, Cretaceous and Paleogene deposits of the USSR - a re-study. Am. Ass. strat. Palynol. Contr. Ser. 23, $211 \mathrm{pp}$.

Lentin, J. K. \& Williams G. L. 1976: A monograph of fossil peridinioid dinoflagellate cysts. Bedford Institute of Oceanography, Report Series. B1-R-75-16, 237 pp.

Lentin, J. K. \& Williams, G. L. 1980: Dinoflagellate provincialism with emphasis on Campanian peridiniaceans. Am. Ass. strat. Palynol. Contr. Ser. 7, 1-46.

Lentin, J. K. \& Williams, G. L. 1987: Status of the fossil dinoflagellate genera Ceratiopsis Vozzhennikova 1963 and Cerodinium Vozzhennikova 1963 emend. Palynology 11, 113-116.

Lentin, J. K. \& Williams G. L. 1993: Fossil dinoflagellates: index to genera and species 1993 edition. Am. Ass. strat. Palynol. Contr. Ser. 28, 856 pp.

McIntyre, D. J. 1974: Palynology of an Upper Cretaceous section, Horton River, District of Mackenzie, N.W.T. Pap. Geol. Surv. Can. 74-14, 57 pp.

McIntyre, D. J. 1975: Morphologic Changes in Deflandrea from a Campanian Section, District of Mackenzie, N.W.T., Canada. Geoscience and Man 11, 61-76.

Manum S. 1963: Some new species of Deflandrea and their probable affinity with Peridinium. Norsk Polarinstitutt Årbok 1962, $55-67$.

Manum, S. \& Cookson, I. C. 1964: Cretaceous microplankton in a sample from Graham Island, arctic Canada, collected during the second "FRAM"-EXPEDITION (1898-1902) with notes on microplankton from the Hassel Formation, Ellef Ringnes Island. Skr. Norske VidenskAkad. Oslo I. Mat.-naturv. Kl. 17, $36 \mathrm{pp}$.

Mao S. \& Mohr, B. A. R. 1992: Late Cretaceous dinoflagellate cysts (?Santonian-Maestrichtian) from the southern Indian Ocean (Hole 748C). Proceedings of the Ocean Drilling program, Scientific Results 120, 307-341.

Marheinecke, U. 1992: Monographie der Dinozysten, Acritarcha und Chlorophyta des Maastrichtium von Hemmoor (Niedersachsen). Palaeontographica B 227, 173 pp.

Marshall, N. G. 1988: A Santonian dinoflagellate assemblage from the Gippsland Basin, southeastern Australia. Mem. Ass. Australasian Palaeontol. 5, 195-215.

Marshall, N. G. 1990: Campanian dinoflagellates from southeastern Australia. Alcheringa 14, 1-38.

May, F. E. 1980: Dinoflagellate cysts of the Gymnodiniaceae, Peridiniaceae and Gonyaulacaceae from the Upper Cretaceous Monmouth Group, Atlantic Highlands, New Jersey. Palaeontographica B 172, 10-116.

Mohr, B. A. R. \& Gee, C. T. 1992: Late Cretaceous palynofloras (sporomorphs and dinocysts) from the Kerguelen Plateau, southern Indian Ocean (Sites 748 and 750). Proceedings of the Ocean Drilling Program, Scientific Results 120, 281-306.
Moshkovitz, S. \& Habib, D. 1993: Calcareous nannofossil and dinoflagellate stratigraphy of the Cretaceous-Tertiary boundary, Alabama and Georgia. Micropaleontology 39, 167-191.

Nichols, D. J. \& Sweet, A. R. 1993: Biostratigraphy of the Upper Cretaceous non-marine palynofloras in a north-south transect of the Western Interior Basin. In Caldwell, W. G. E. \& Kauuffman, E. G. (ed.) Evolution of the Western Interior Basin. Spec. Pap. Geol. Ass. Can. 39, 539-584.

Nøhr-Hansen, H. 1993: Upper Maastrichtian? - lower Paleocene dinoflagellate cysts and pollen from turbidites in the Itilli region, Nuussuaq, central West Greenland - first dating of sediments. Rapp. Grønlands geol. Unders. 159, 81-87.

Nøhr-Hansen, H. 1994a: Dinoflagellate cyst biostratigraphy of the Upper Cretaceous black mudstone on Svartenhuk Halvø, West Greenland. Open File Ser. Gronlands geol. Unders. 94/9, 25pp.

Nøhr-Hansen, H. 1994b: Dinoflagellate cyst biostratigraphy of the Upper Cretaceous black mudstone on central Nuussuaq, West Greenland. Open File Ser. Gronlands geol. Unders. 94/12, 26pp.

Nøhr-Hansen, H. 1994c: Dinoflagellate cyst biostratigraphy of the Upper Cretaceous black mudstones between Niaqornat and Ikorfat on the north coast of Nuussuaq, West Greenland. Open File Ser. Grønlands geol. Unders. 94/14, 24 pp.

Núñez-Betelu, L. (Koldo) \& Hills, L. V. 1992: Preliminary paleopalynology of the Kanguk Formation (Upper Cretaceous), Remus Creek, Canadian Arctic Archipelago: I. Marine Palynomorphs. Rev. Española Paleont. 7, 185-196.

Núñez-Betelu, L. (Koldo) 1994: Sequence stratigraphy of a coastal to offshore transition, Upper Cretaceous Kanguk Formation: a palynological, sedimentological and Rock-Eval characterization of a depositional sequence, northeastern Sverdrup Basin, Canadian Arctic. Unpublished Ph.D. thesis, Department of Geology and Geophysics, University of Calgary, 569pp.

Núñez-Betelu, L. (Koldo), Hills, L. V., Krause, F. F. \& McIntyre, D. J. 1994: Upper Cretaceous paleoshorelines of the northeastern Sverdrup Basin, Ellesmere Island, Canadian Arctic Archipelago. Abstract International conference on arctic margins, Magadan Russia, September 6-10.13 pp.

Pedersen, A. K. 1985: Lithostratigraphy of the Tertiary Vaigat Formation on Disko, central West Greenland. Rapp. Grønlands geol. Unders. 69, 25-32.

Pedersen, G. K. \& Pulvertaft, T. C. R. 1992: The nonmarine Cretaceous of the West Greenland Basin, onshore West Greenland. Cretaceous Res. 13, 263-272.

Piasecki, S., Larsen, L. M., Pedersen, A. K. \& Pedersen, G. K. 1992: Palynostratigraphy of the Lower Tertiary volcanics and marine clastic sediments in the southern part of West Greenland Basin: implications for the timing and duration of the volcanism. Rapp. Grønlands geol. Unders. 154, 13-31.

Powell, A. J. 1992: Dinoflagellate cysts of the Tertiary System. In Powell, A. J. (ed.) A stratigraphic Index of Dinoflagellate Cysts, 155-252. British Micropalaeontological Society.

Prössl, K. F. 1990: Dinoflagellaten der Kreide - Unter-Hauterive bis Ober-Turon - im Niedersächsischen Becken. Stratigraphie und fazies in der kernbohrung Kontad 101 sowie einiger anderer bohrungen in Nordwestdeutschland. Palaeontographica B 218, 93-191. 
Pulvertaft, T. C. R. 1979: Lower fluvial-deltaic sediments at Kûk, Nûgssuaq West Greenland. Bull. geol. Soc. Denmark 28, 5772.

Pulvertaft, T. C. R. 1987: Status review of the results of stratigraphical and sedimentological investigations in the Cretaceous-Tertiary of West Greenland, and recommendation for new GGU activity in these fields. Unpublished intern. GGU rep., 18pp.

Robaszynski, F. \& Amédro, F. et al. 1980: Synthèse biostratigraphique de l'Aptien au Santonien du Boulonnais a partir de sept groupes Paléontologiques: foraminifères, nannoplancton, dinoflagellés et macrofaunes. Zonations micropaléontologiques intégrées dans de cadre du Crétacé boréal nord-européen. Rev. Micropaléont. 22 (4), 195-311.

Robaszynski, F. et al. 1983: La limite Campanien-Maastrichtien dans le Limbourg belgo-neerlandais. Géologie Méditerranéenne 10 (3-4), 59-72.

Rolle, F. 1985: Late Cretaceous - Tertiary sediments offshore central West Greenland: lithostratigraphy, sedimentary evolution, and petroleum potential. Can. J. Earth Sci. 22, 1001-1019.

Rosenkrantz, A. 1970: Marine Upper Cretaceous and lowermost Tertiary deposits in West Greenland. Meddr dansk geol. Foren. 19, 406-453.

Rosenkrantz, A. \& Pulvertaft, T. C. R. 1969: Cretaceous-Tertiary stratigraphy and tectonics in northern West Greenland. Mem. Am. Ass. Petrol. Geol. 12, 883-898.

Schiener, E. J. 1975: Sedimentological notes on sandstones from Nûgssuaq, central West Greenland. Rapp. Gronlands geol. Unders. 69, 35-44.

Schiøler, P. 1992: Dinoflagellate cysts from the Arnager Limestone Formation (Coniacian, Late Cretaceous), Bornholm, Denmark. Rev. Palaeobot. Palynol. 72, 1-25.

Schiøler, P. \& Wilson, G. J. 1993: Maastrichtian dinoflagellate zonation in the Dan Field, Danish North Sea. Rev. Palaeobot. Palynol. 78, 321-351.

Singh, C. 1971: Lower Cretaceous microfloras of the Peace River area, northwestern Alberta. Bull. Alberta Res. Coun. 28, 301 pp.

Srivastava, S. K. 1994: Palynology of the Cretaceous-Tertiary boundary in the Scollard Formation of Alberta, Canada, and global KTB events. Rev. Palaeobot. Palynol. 83, 137-158.

Stanley, E. A. 1965: Upper Cretaceous and Paleocene plant microfossils and Paleocene dinoflagellates and hystrichosphaerids from Northwestern South Dakota. Bull. Am. Paleont. 49 (222), 175-384.

Stone, J. F. 1973: Palynology of the Almond Formation (Upper Cretaceous), Rock Springs Uplift, Wyoming. Bull. Am. Paleont. 64 (278), 135 pp.

Stover, L. E. \& Evitt, W. R. 1978: Analyses of pre-Pleistocene organic-walled dinoflagellates. Stanford Univ. Publ., Geol. Sci. $15,300 \mathrm{pp}$.

Sweet, A. R. \& McIntyre, D. J. 1988: Late Turonian marine and nonmarine palynomorphs from the Cardium Formation, northcentral Alberta Foothills, Canada. In James, D. P. \& Leckie, D. A. (ed.) Sequences, stratigraphy, sedimentology; surface and subsurface. Mem. Can. Soc. Petrol. Geol. 15, 499-516.

Sweet, A. R., Ricketts, B. D., Cameron, A. R. \& Norris, D. K. 1989: An integrated analysis of the Brackett Coal Basin, North- west Territories. Pap. Geol Surv. Can. 98-1G, 85-99. 499516.

Tocher, B. A. 1987: 14. Campanian to Maestrichtian dinoflagellate cysts from the United States Atlantic Margin, deep sea drilling project site 612. Initial Reports of the Deep Sea Drilling Project 95, 419-428.

Tocher, B. A. \& Jarvis, I. 1987: Dinoflagellate cysts and stratigraphy of the Turonian (Upper Cretaceous) chalk near Beer, southeast Devon, England. In Hart, M. B. (ed.) Micropalaeontology of carbonate environments, 138-175. Spec. Publ. British Micropalaeontological Society. Chichester: Ellis Horwood.

Traverse, A. 1988: Paleopalynology, 600 pp. Allen \& Unwin Inc. U.S.A.

Yun, Hye-Su 1981: Dinoflagellaten aus der Oberkreide (Santon) von Westfalen. Palaeontographica B 177, 89 pp.

Vozzhennikova, T. F. 1967: [Fossil peridinians of the Jurassic, Cretaceous and Palaeogene deposits of the USSR] $347 \mathrm{pp}$. Trudy Akad. Nauk SSSR, Sib. Otd, Inst. Geol. Geof. (English translation by E. Lees. W. A. S. Sarjeant (ed.) 1971 National lending Library for Science and Technology $453 \mathrm{pp}$.)

Wall, J. H. \& Singh, C. 1975: A Late Cretaceous Microfossil Assemblage from the Buffalo Head Hills, North-Central Alberta. Can. J. Earth Sci. 12, 1157-1174.

Westin, H. 1992: Cretaceous dinoflagellate cyst stratigraphy of the Höllviken 1 well, Scania, Southern Sweden. Doctoral Dissertation 1992. Oslo: Norsk Hydro, 175 pp., 22 Plates.

Williams, G. L. 1975: Dinoflagellate and spore stratigraphy of the Mesozoic-Cenozoic, offshore Eastern Canada. In Offshore geology of Eastern Canada. Pap. Geol. Surv. Can. 74-30, $107-$ 161.

Williams, G. L. \& Brideaux, W. W. 1975: Palynologic analyses of Upper Mesozoic and Cenozoic rocks of the Grand Banks, Atlantic Continental Margin. Bull. Geol. Surv. Can. 236, 163pp.

Williams, G. L. \& Bujak, J. P. 1977a: Cenozoic palynostratigraphy of offshore eastern Canada; In W. C. Elsik (ed.) Contributions of stratigraphic palynology (with emphasis on North America) Volume 1, Cenozoic Palynology. Am. Ass. strat. Palynol. Contr. Ser. 5A, 14-47.

Williams, G. L. \& Bujak, J. P. 1977b: Distribution patterns of some North Atlantic Cenozoic dinoflagellate cysts. Marine Micropaleontology 2, 223-233.

Williams, G. L. \& Bujak, J. P. 1985: Mesozoic and Cenozoic dinoflagellates. In Bolli, H. M., Saunders, J. B. \& Perch-Nielsen, K. (ed.) Plankton Stratigraphy, 847-964. Cambridge Earth Science Series, Cambridge University Press.

Williams, G. L., Jansa, L. F., Clark, D. F. \& Ascoli, P. 1974: Geology of the Shell Naskapi N-30 well, Scotian Shelf, eastern Canada. Pap. Geol. Surv. Can. 74-50, 12 pp.

Williams, G. L., Ascoli, P., Barss, M. S., Bujak, J. P., Davies, E. H., Fensome, R. A. \& Williamson, M. A. 1990: Biostratigraphy and related studies. Chapter 3. In Kenn, M. J. \& Williams, G. L. (ed.) Geology of the Continental Margin of Eastern Canada. Geology of Canada 2, 87-137. Ottawa: Geological Survey of Canada.

Williams, G. L., Stover, L. E. \& Kidson, E. J. 1993: Morphology and stratigraphic ranges of selected Mesozoic-Cenozoic dinoflagellate taxa in the northern hemisphere. Pap. Geol. Surv. Can. 92-10, 137 pp. 
Enclosures 1, 13, 33 \& 39 in pocket on back cover 

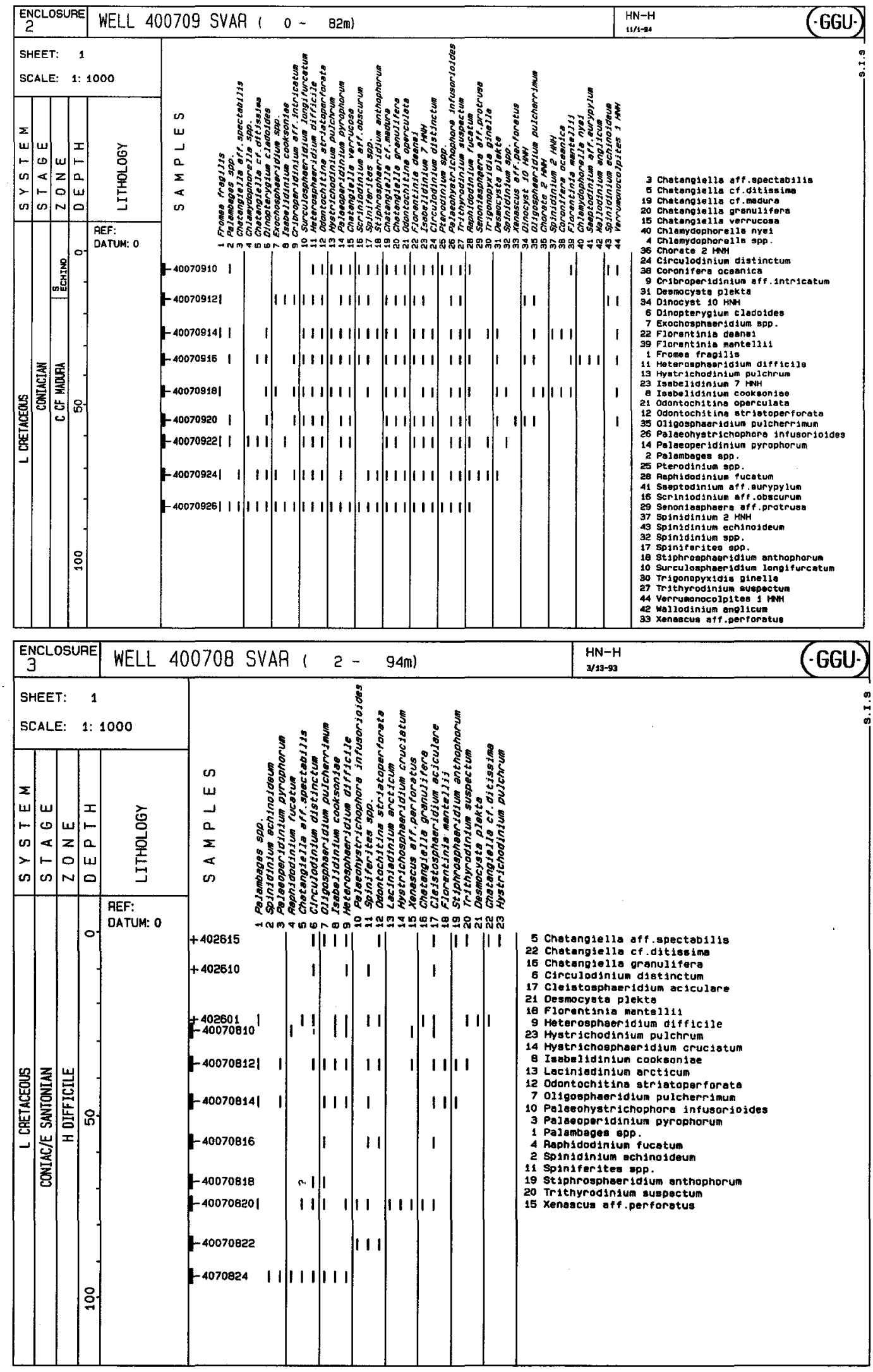

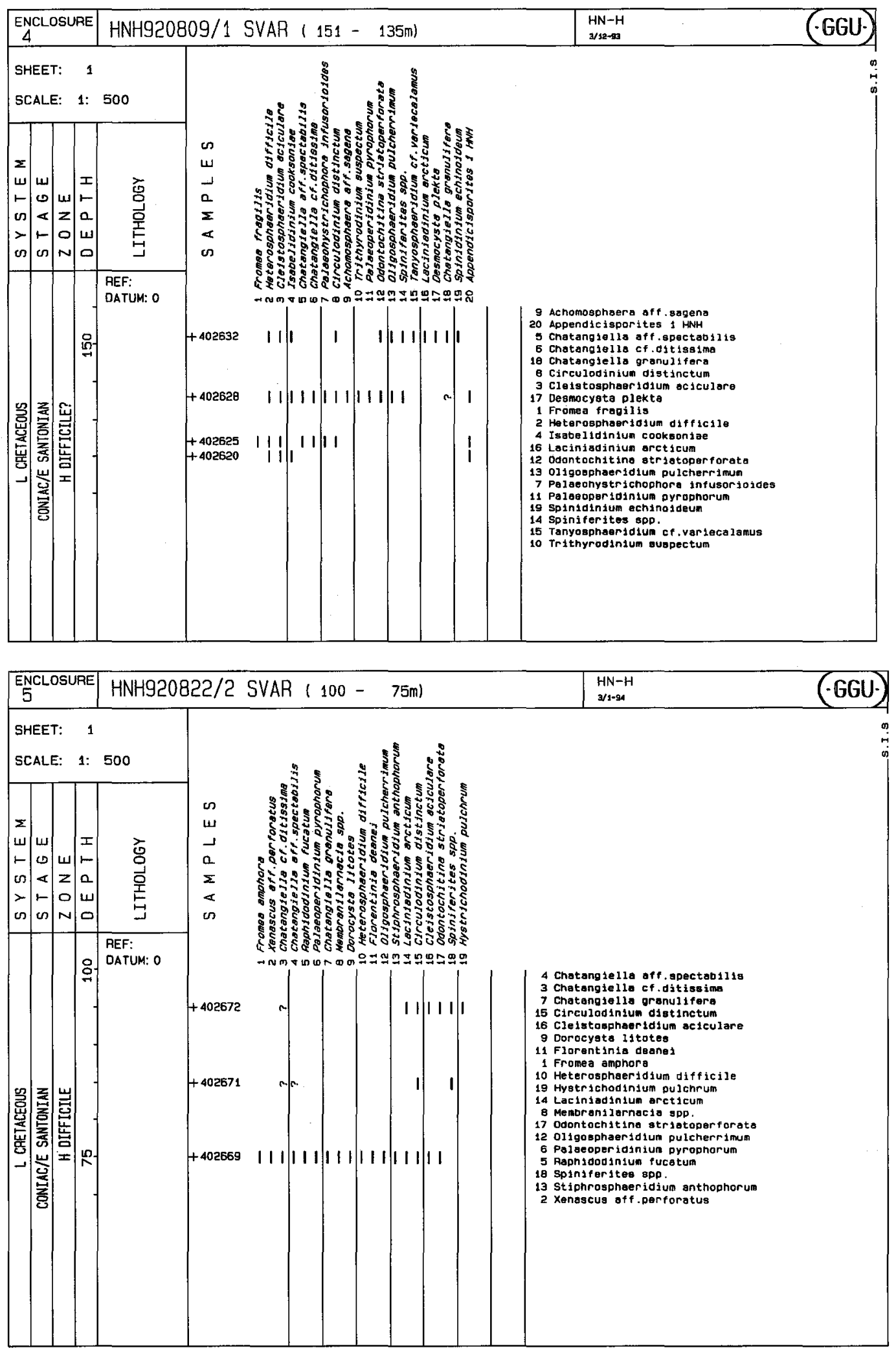


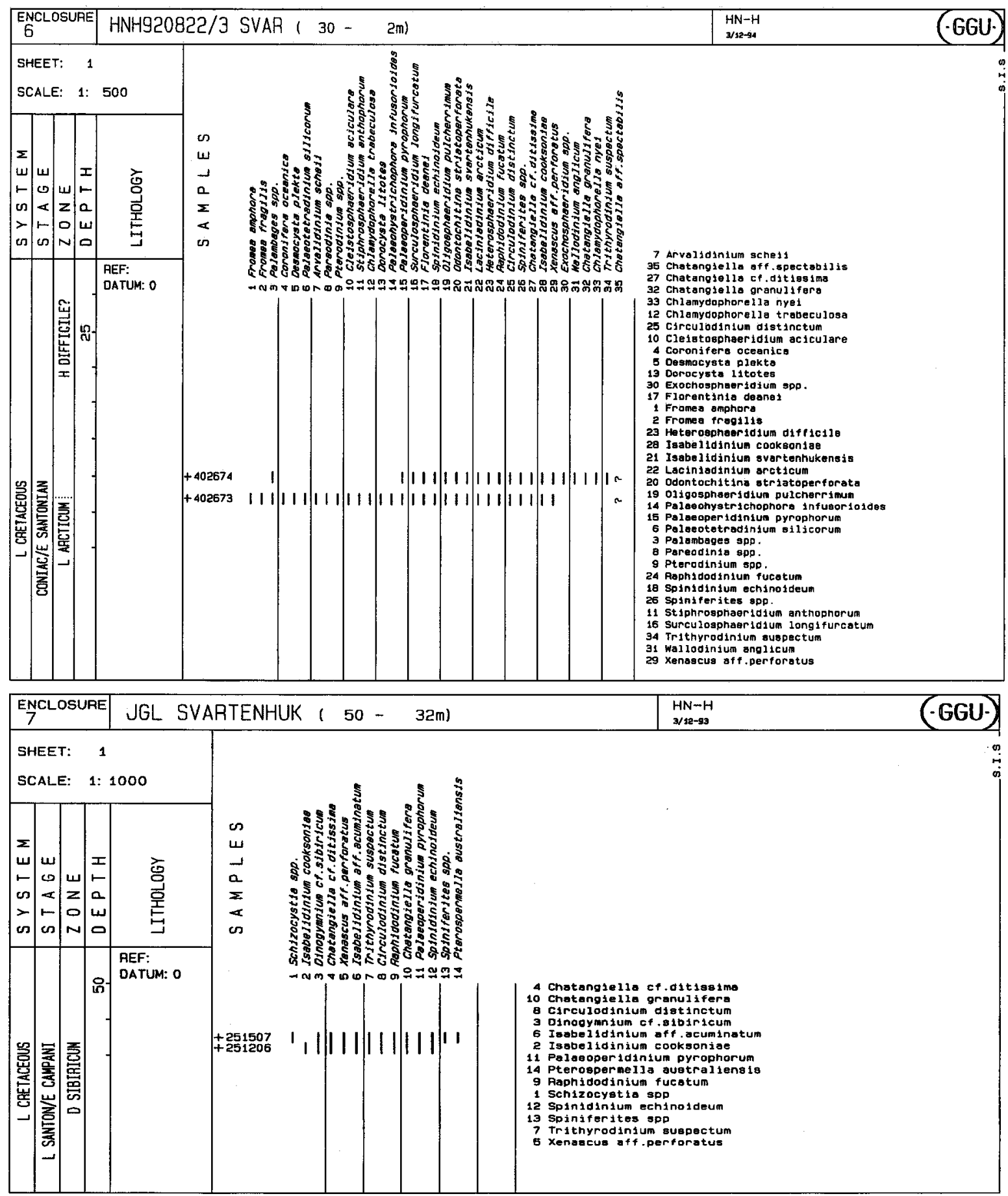




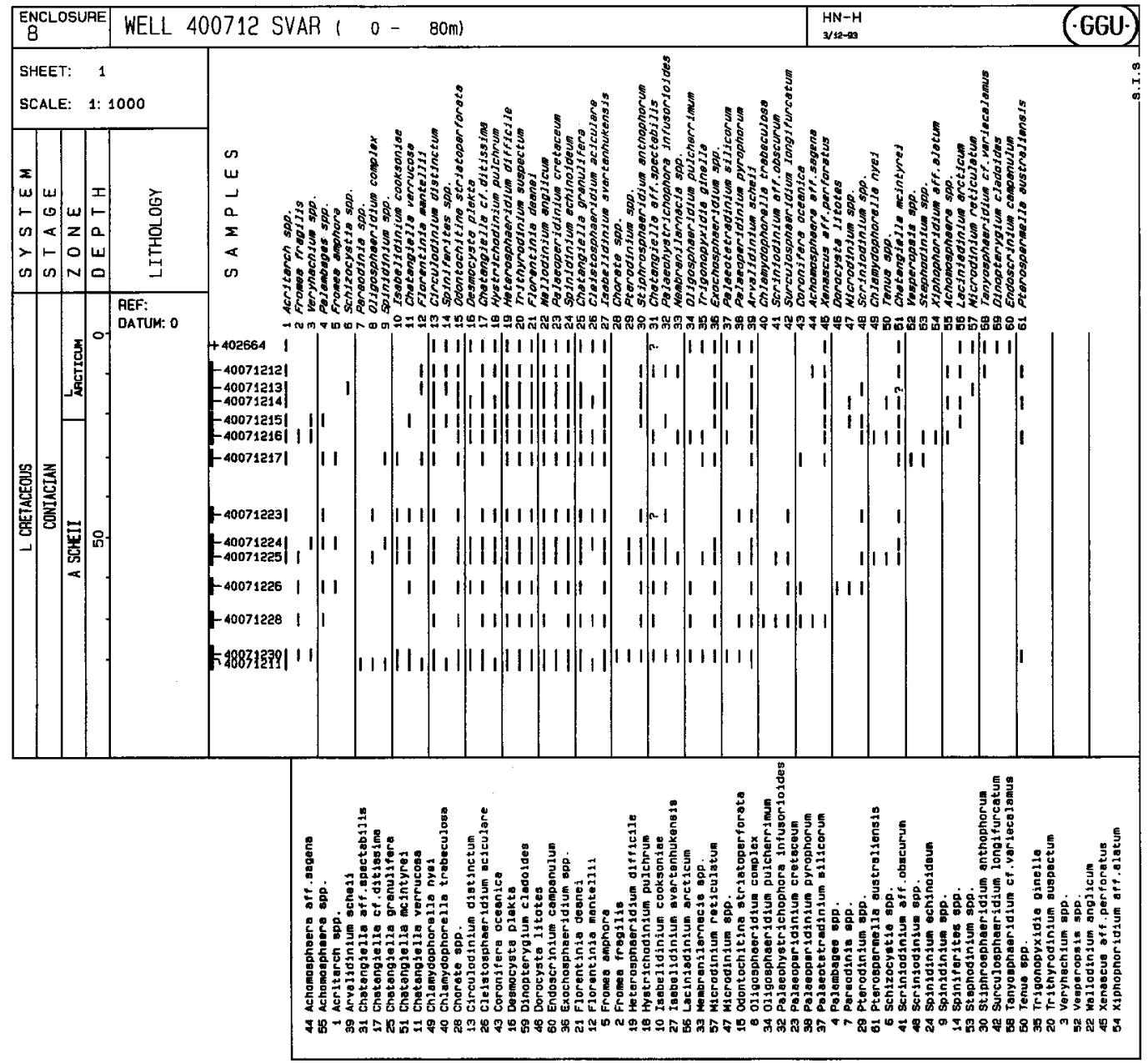

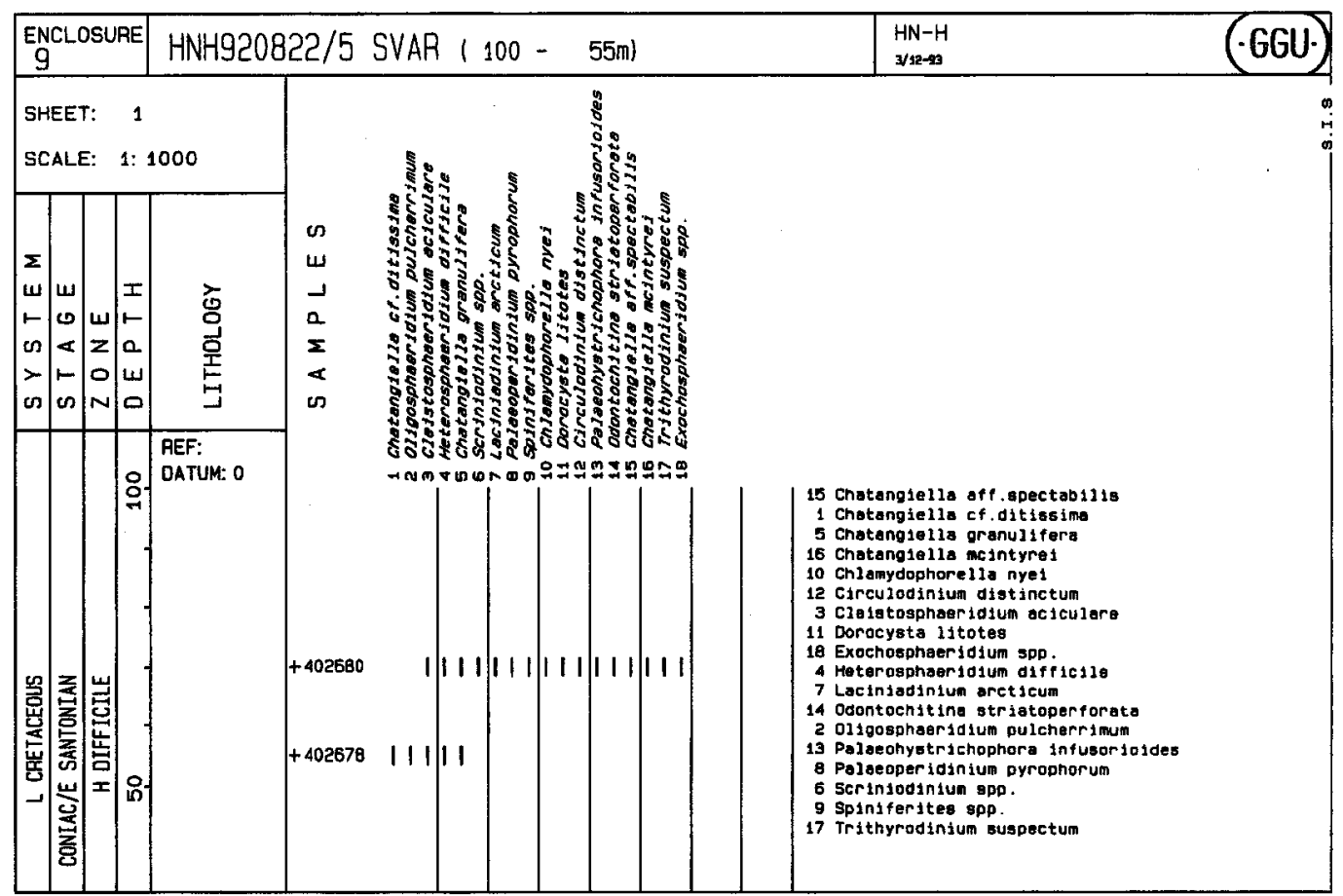



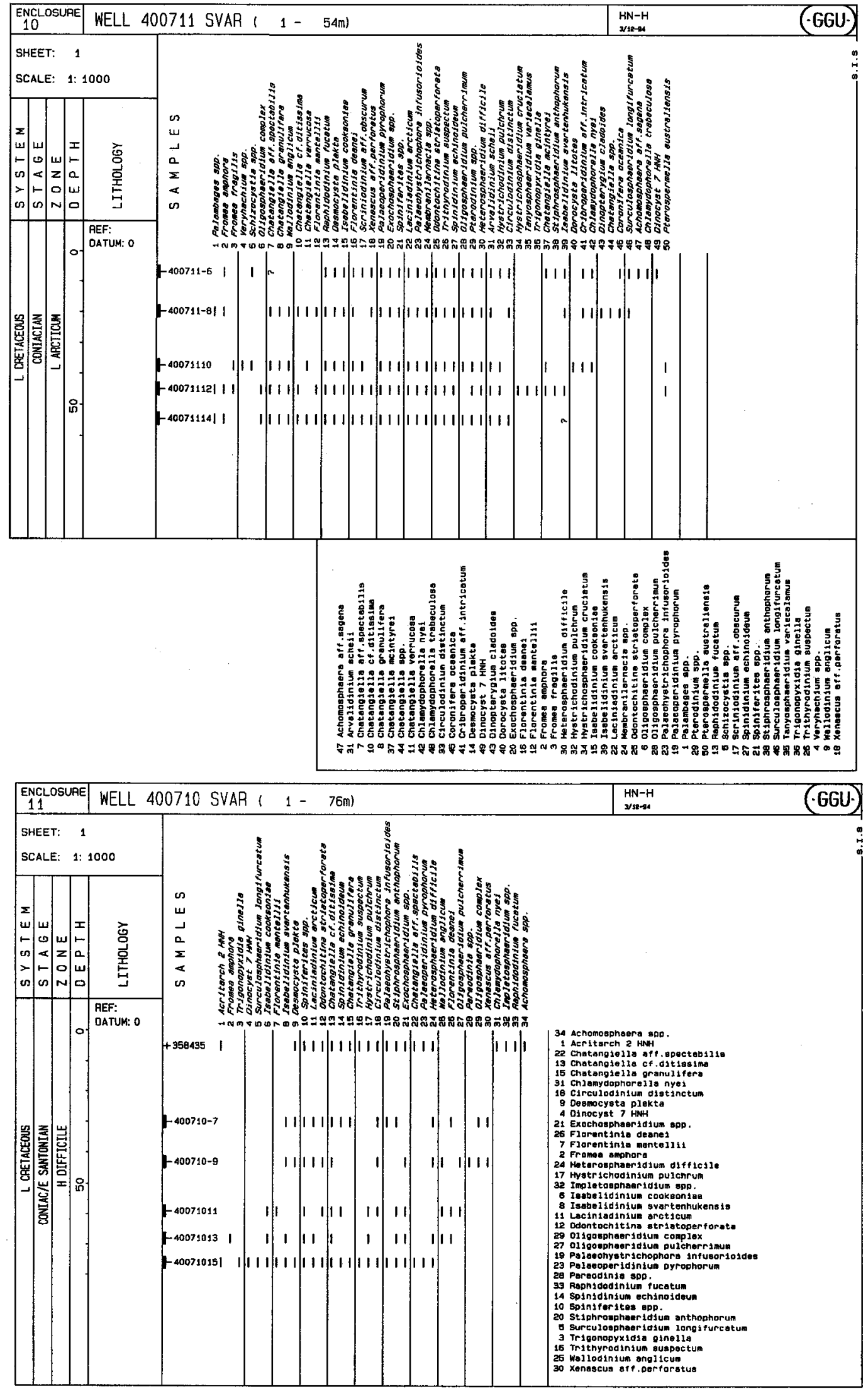


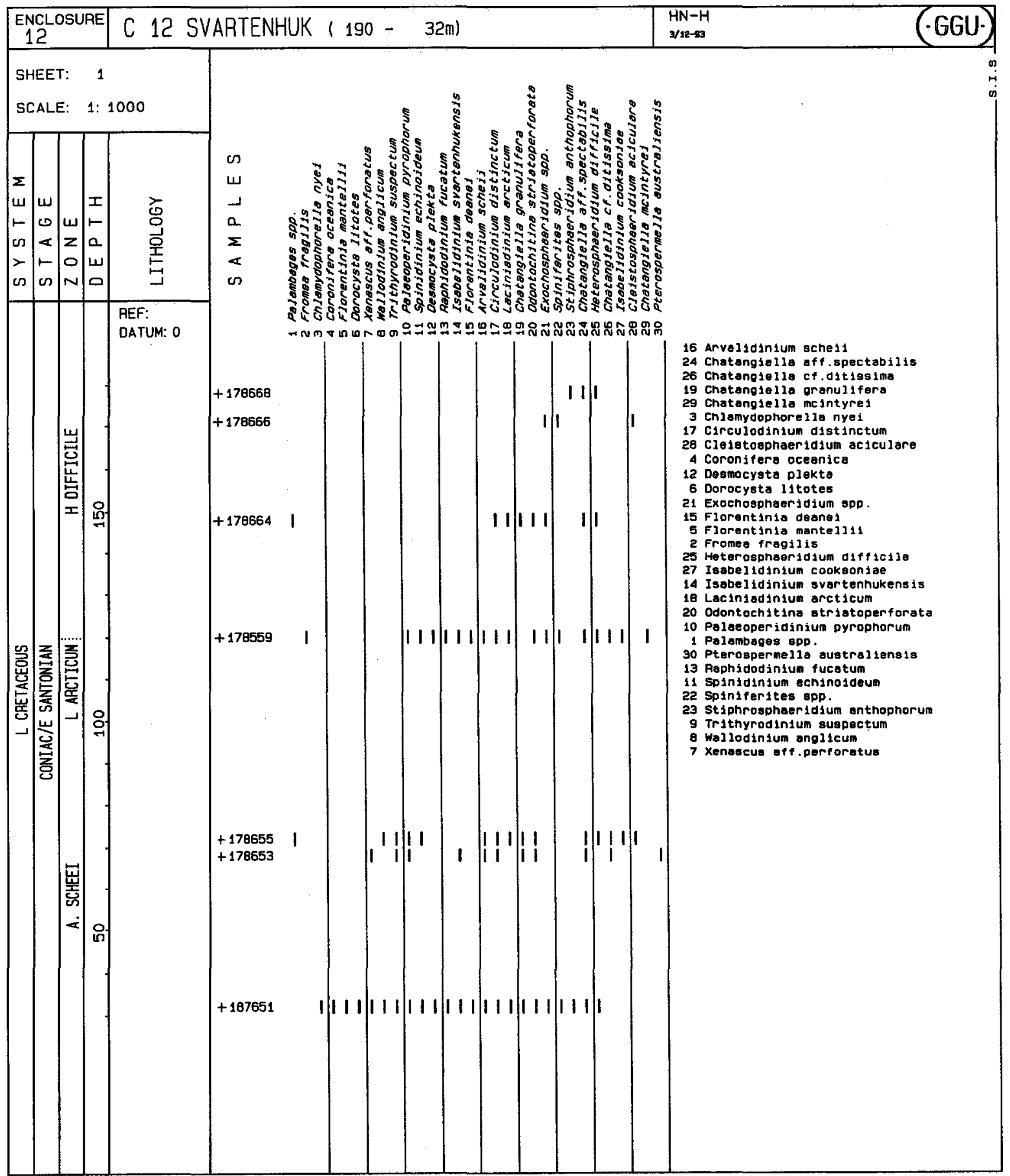

Enclosure 13 in pocket 

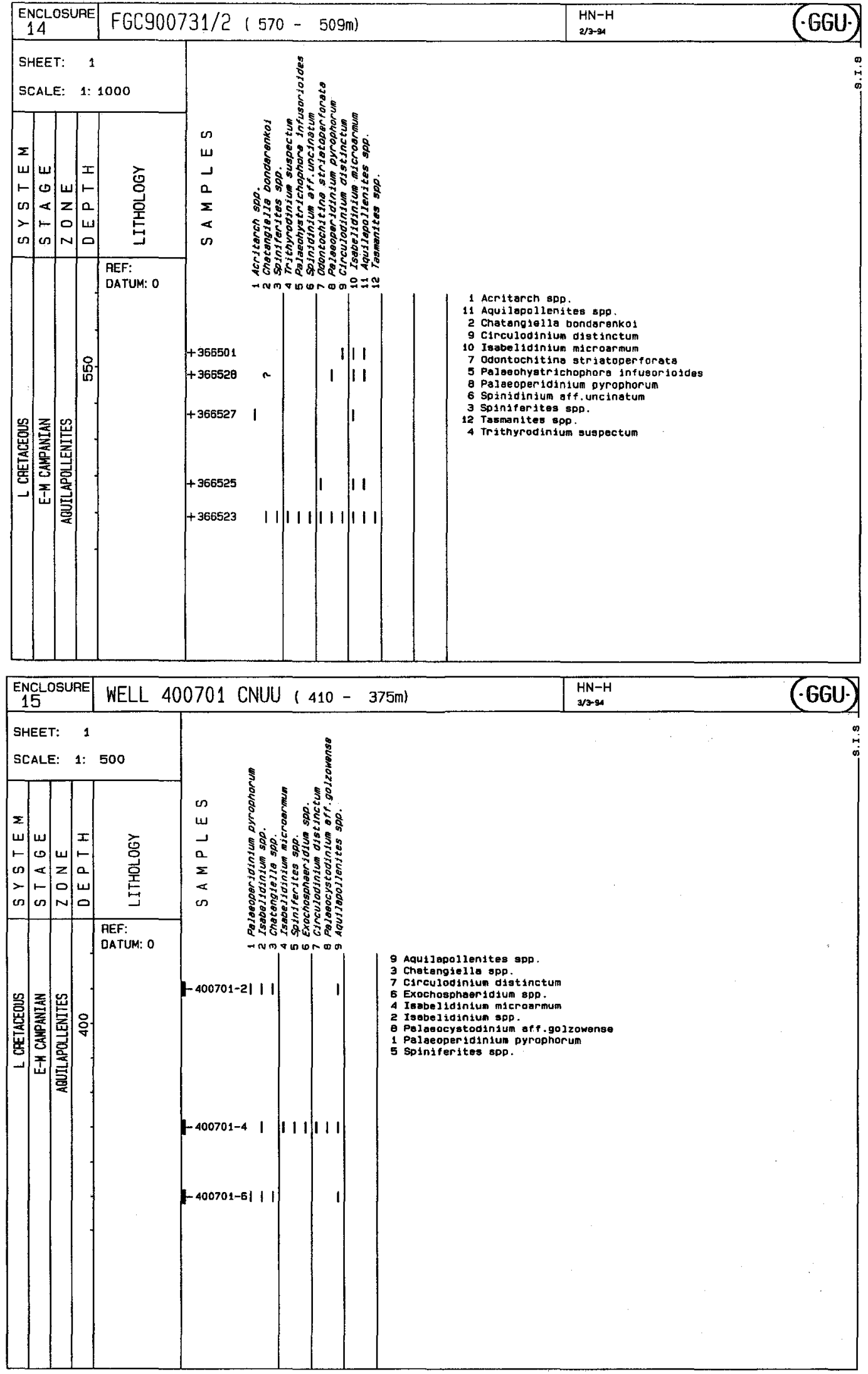


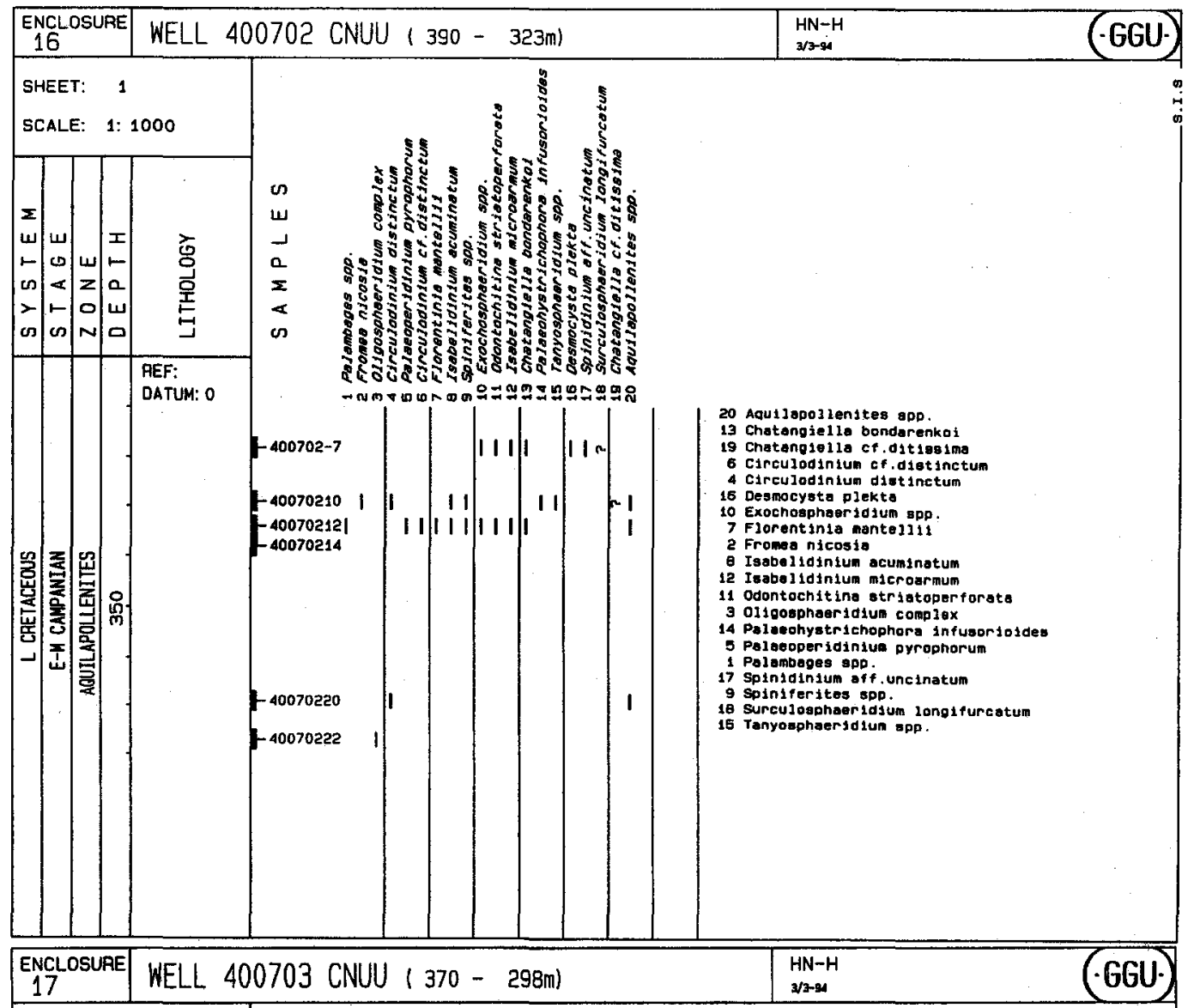

SHEET: 1

SCALE: 1: 1000

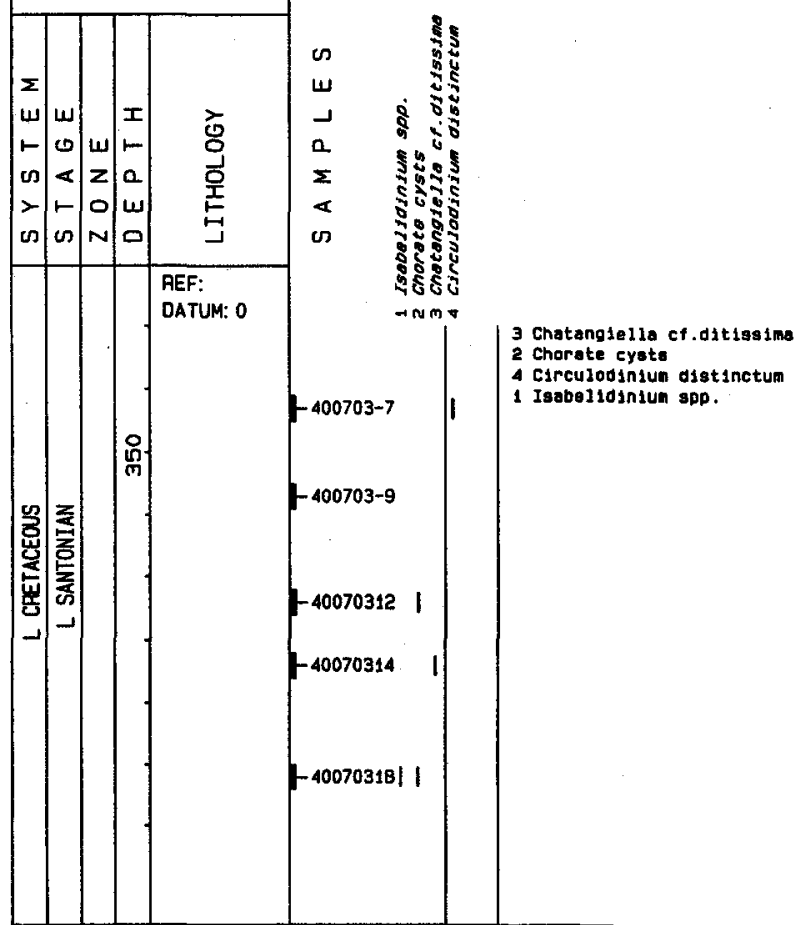




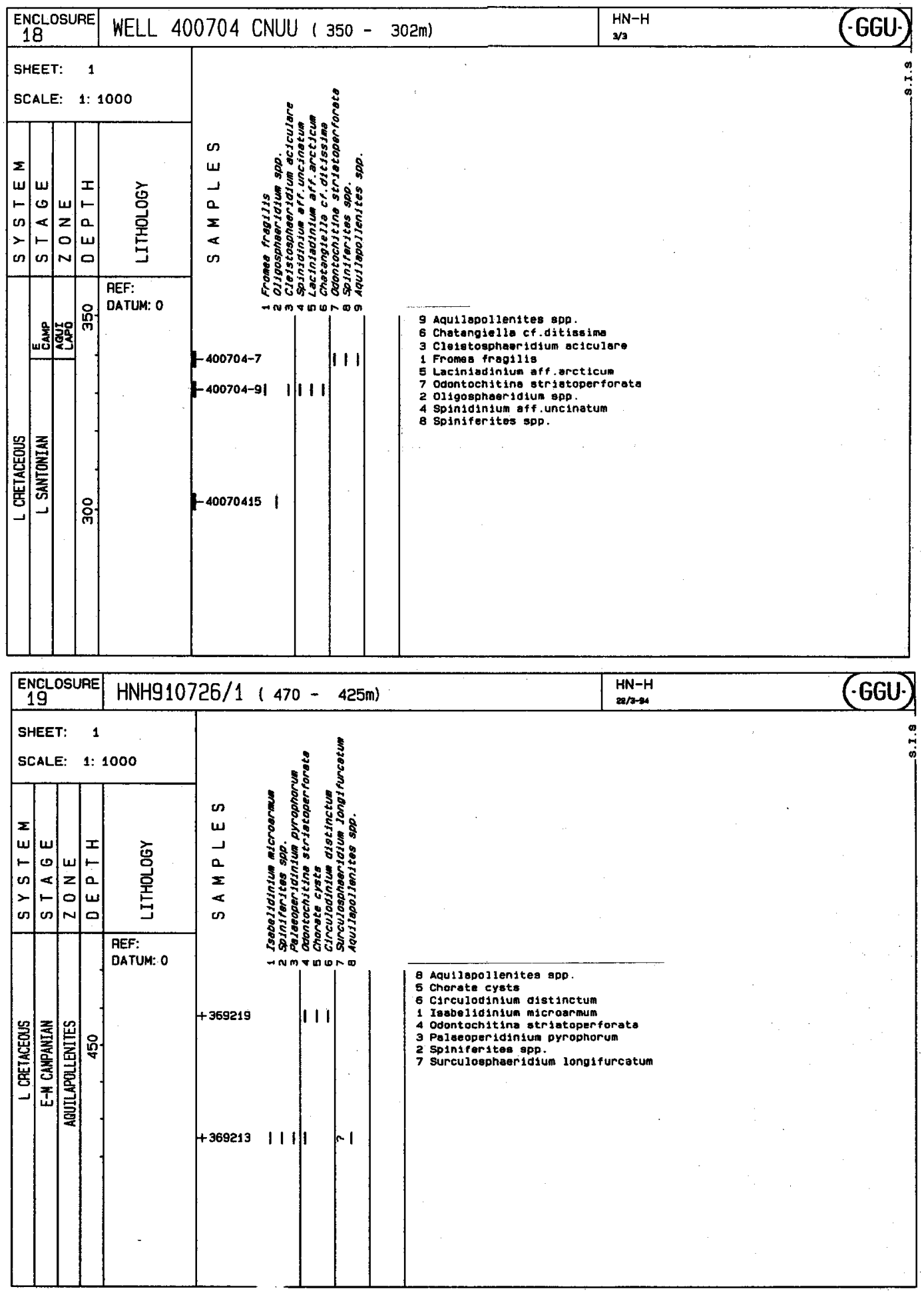




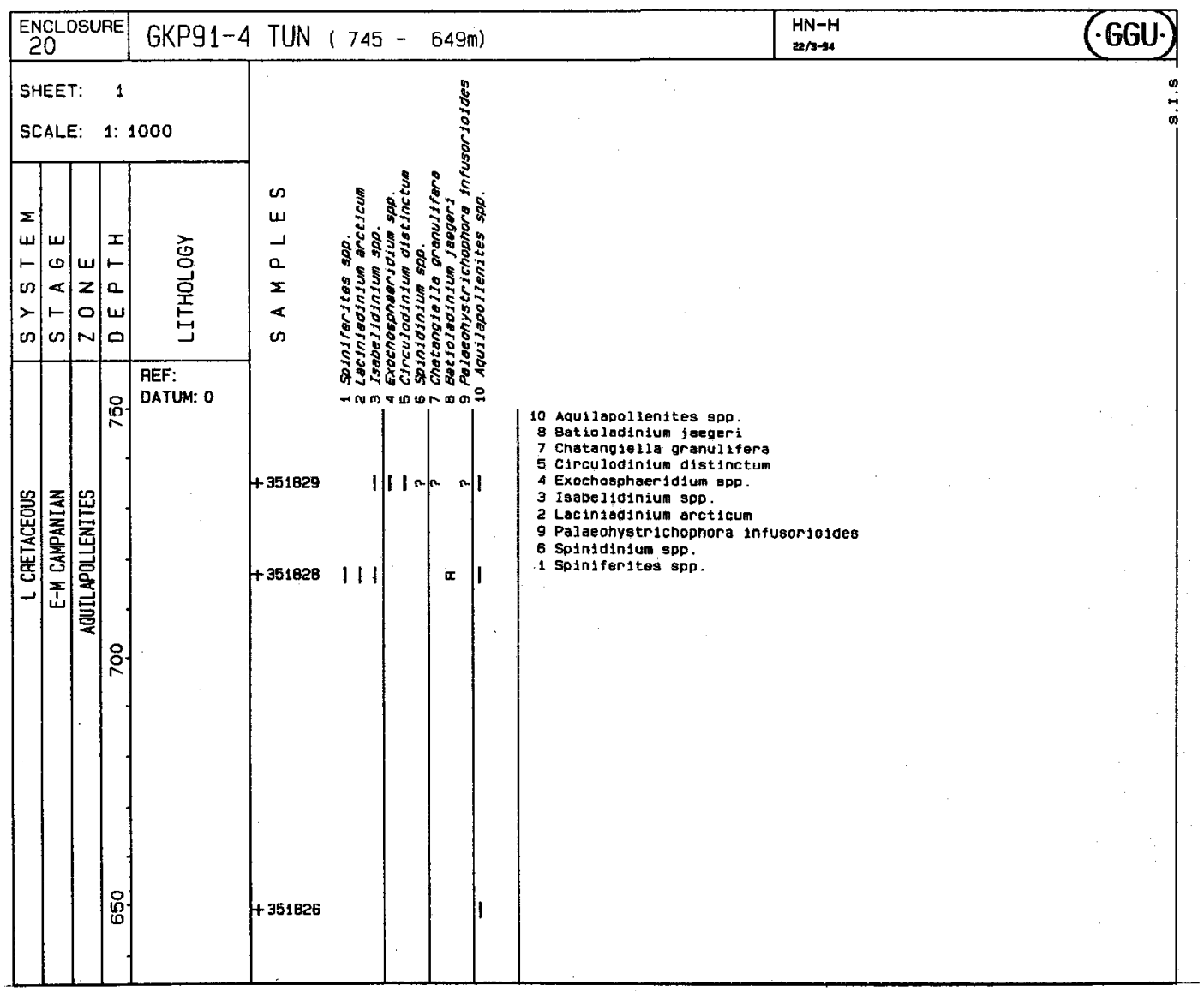

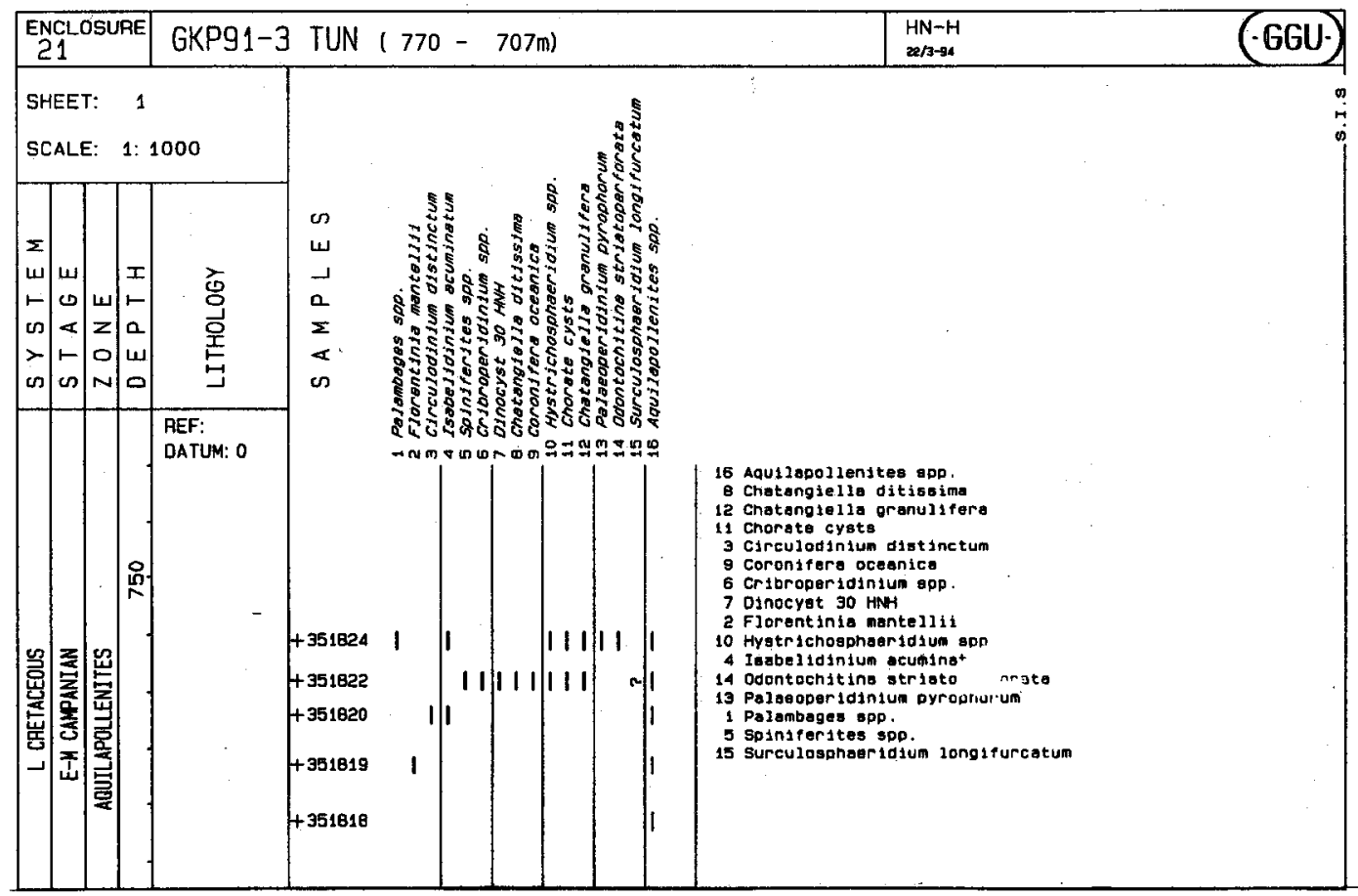



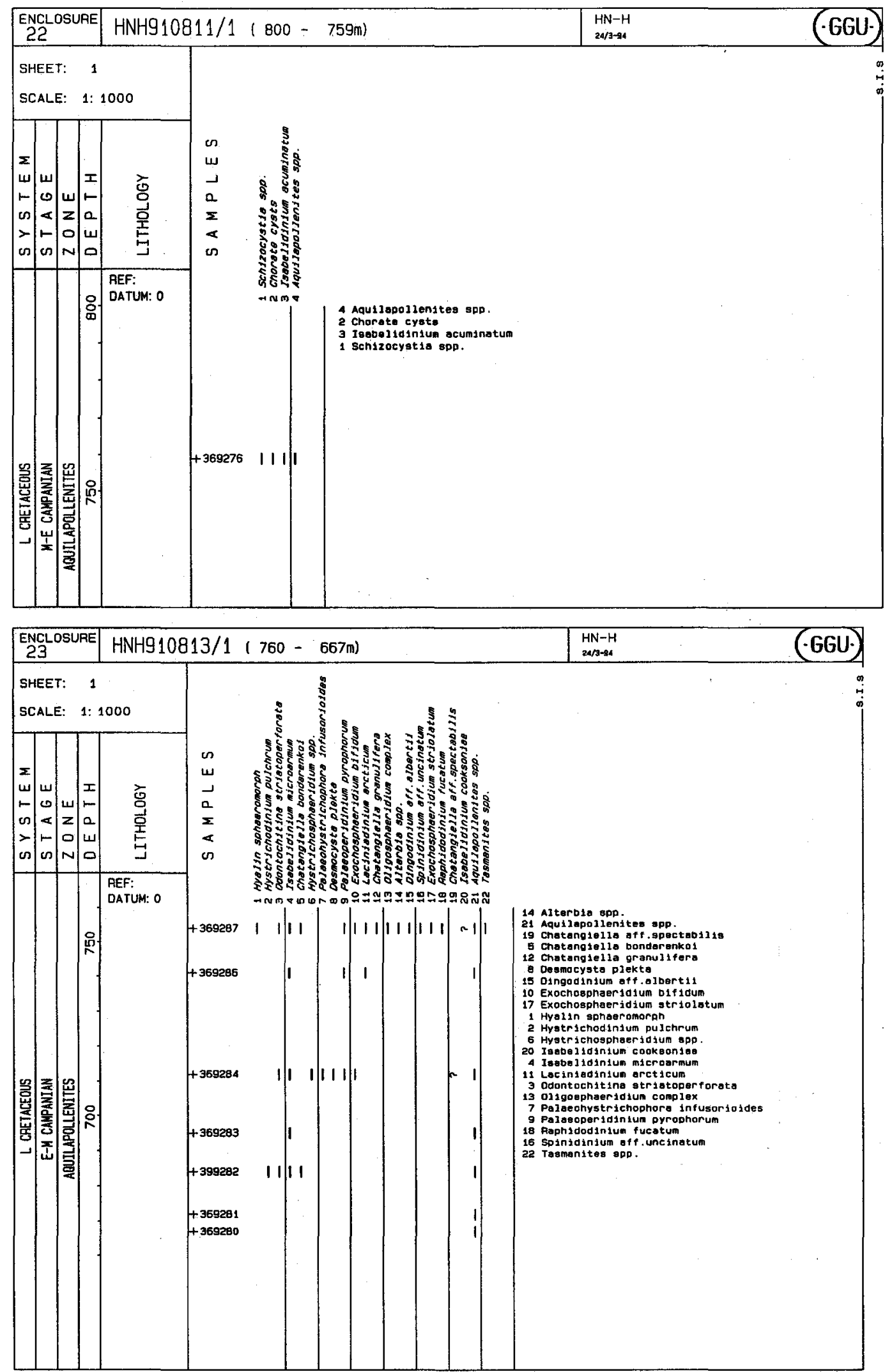


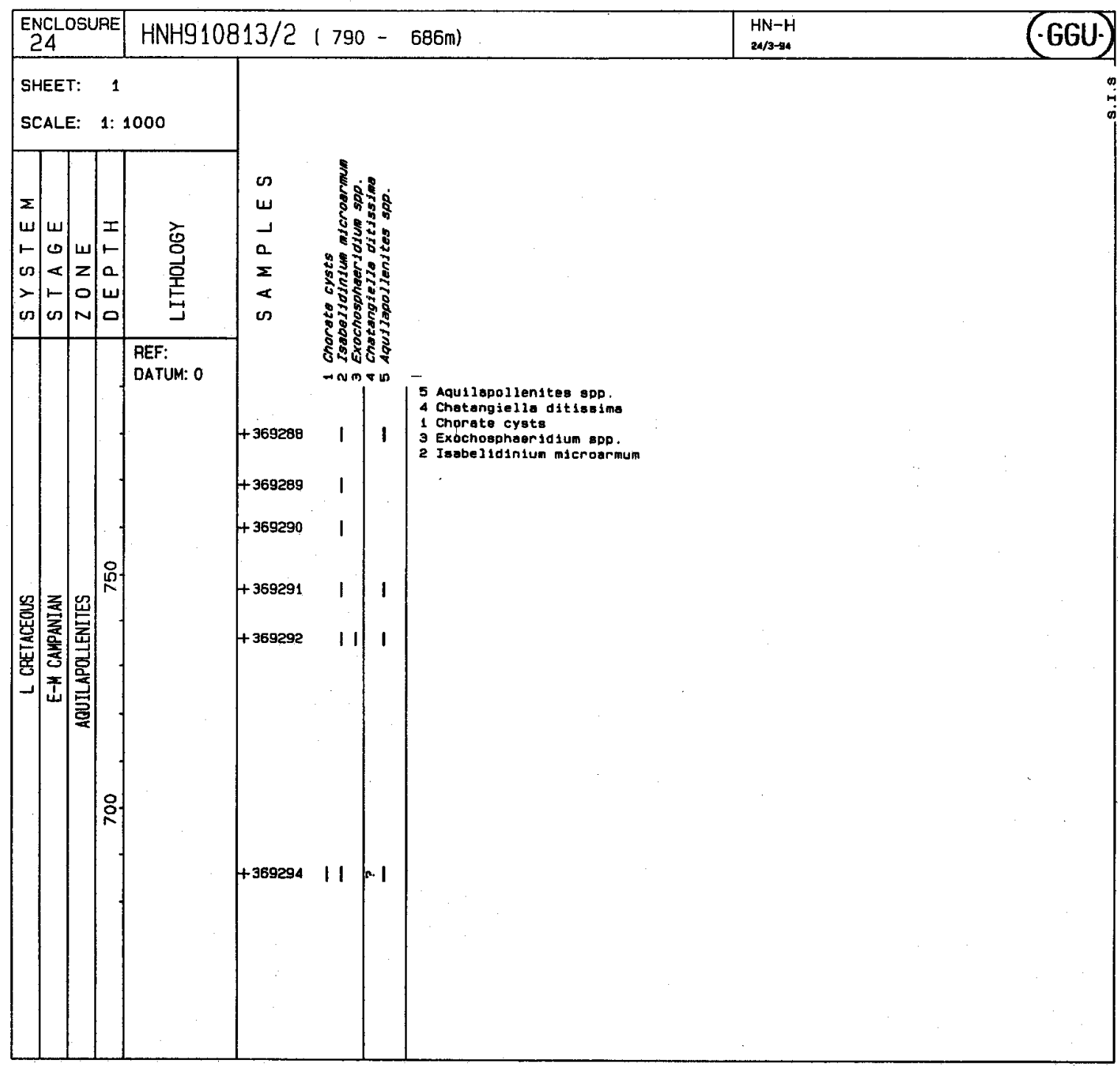




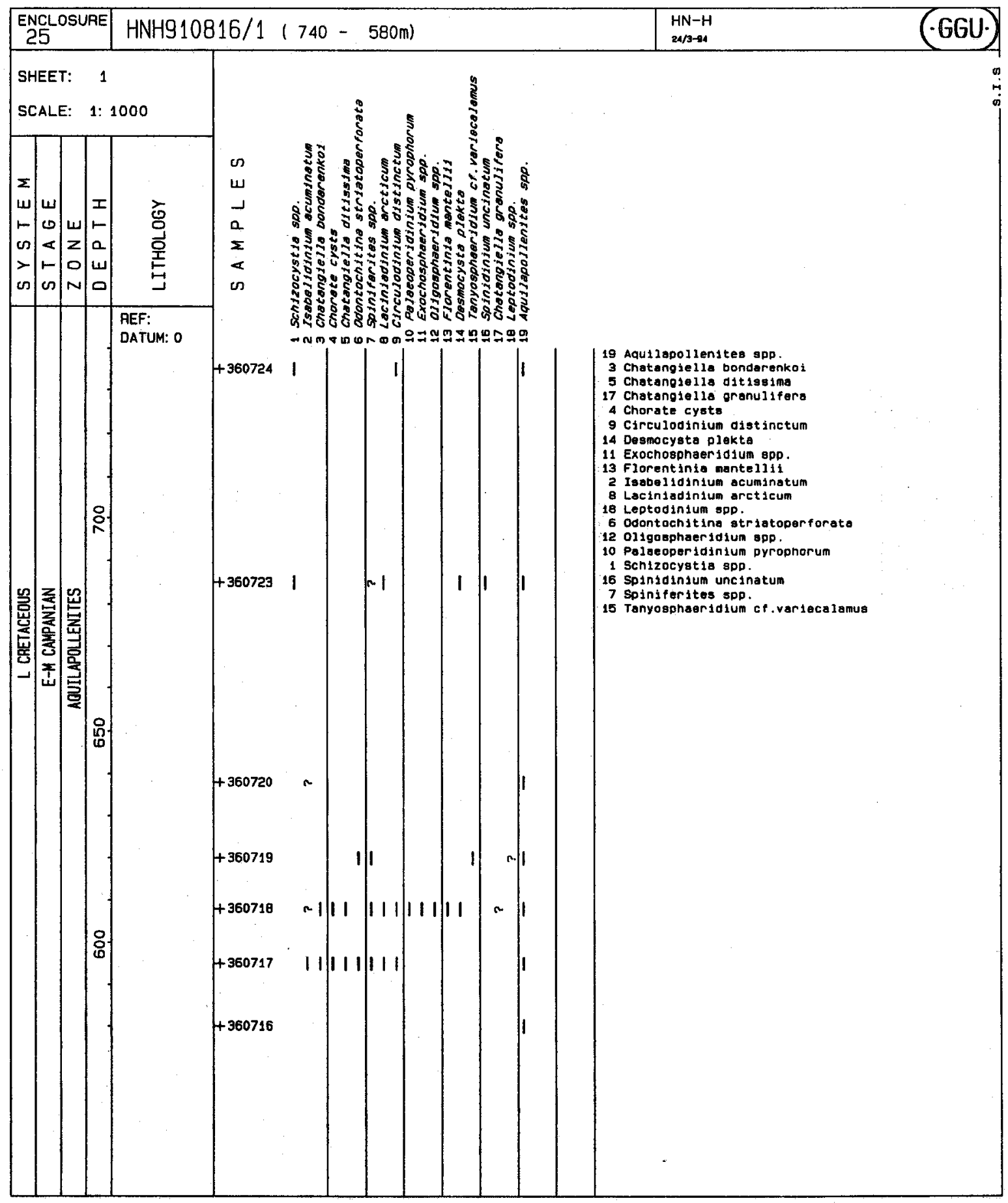




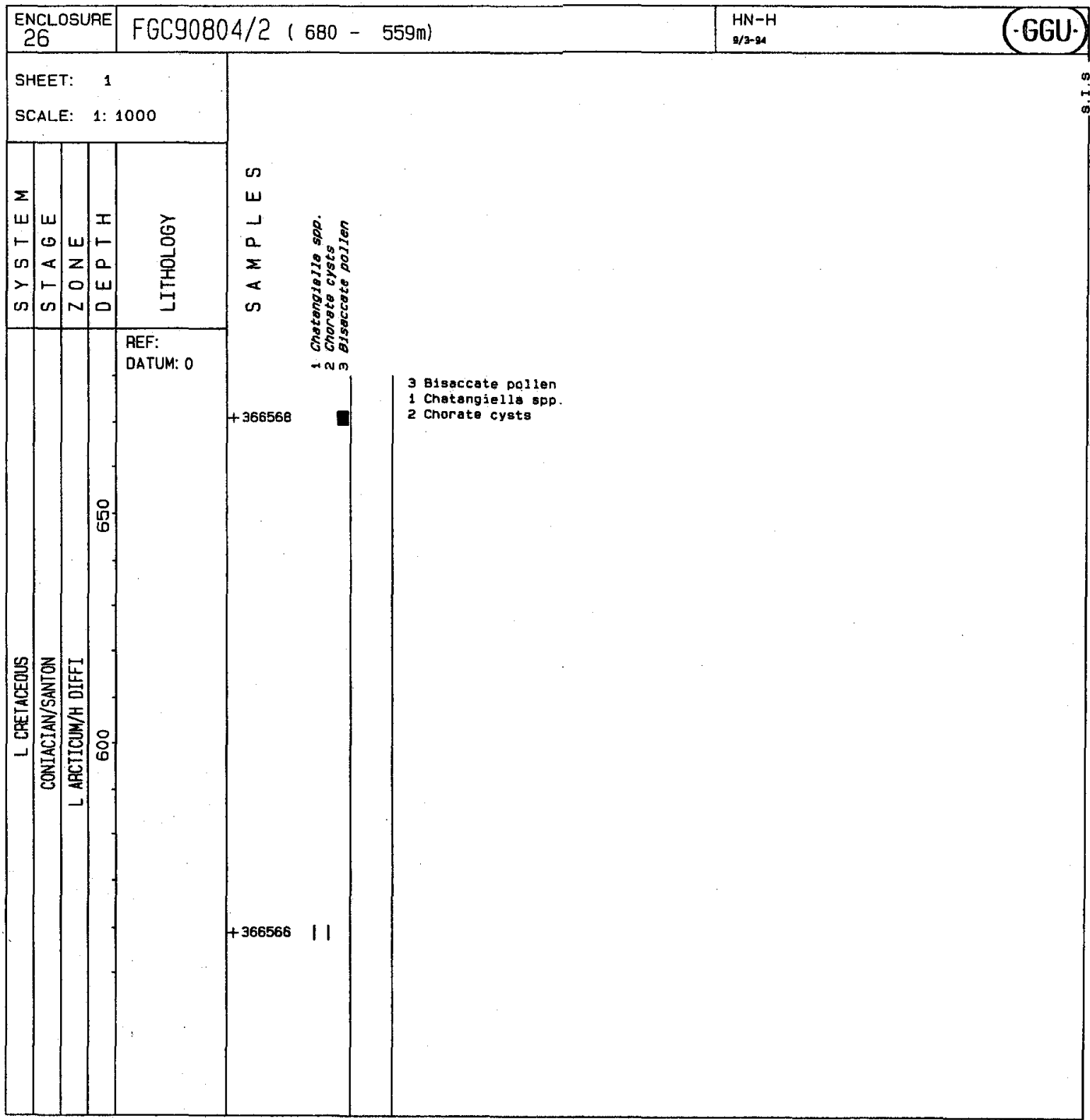



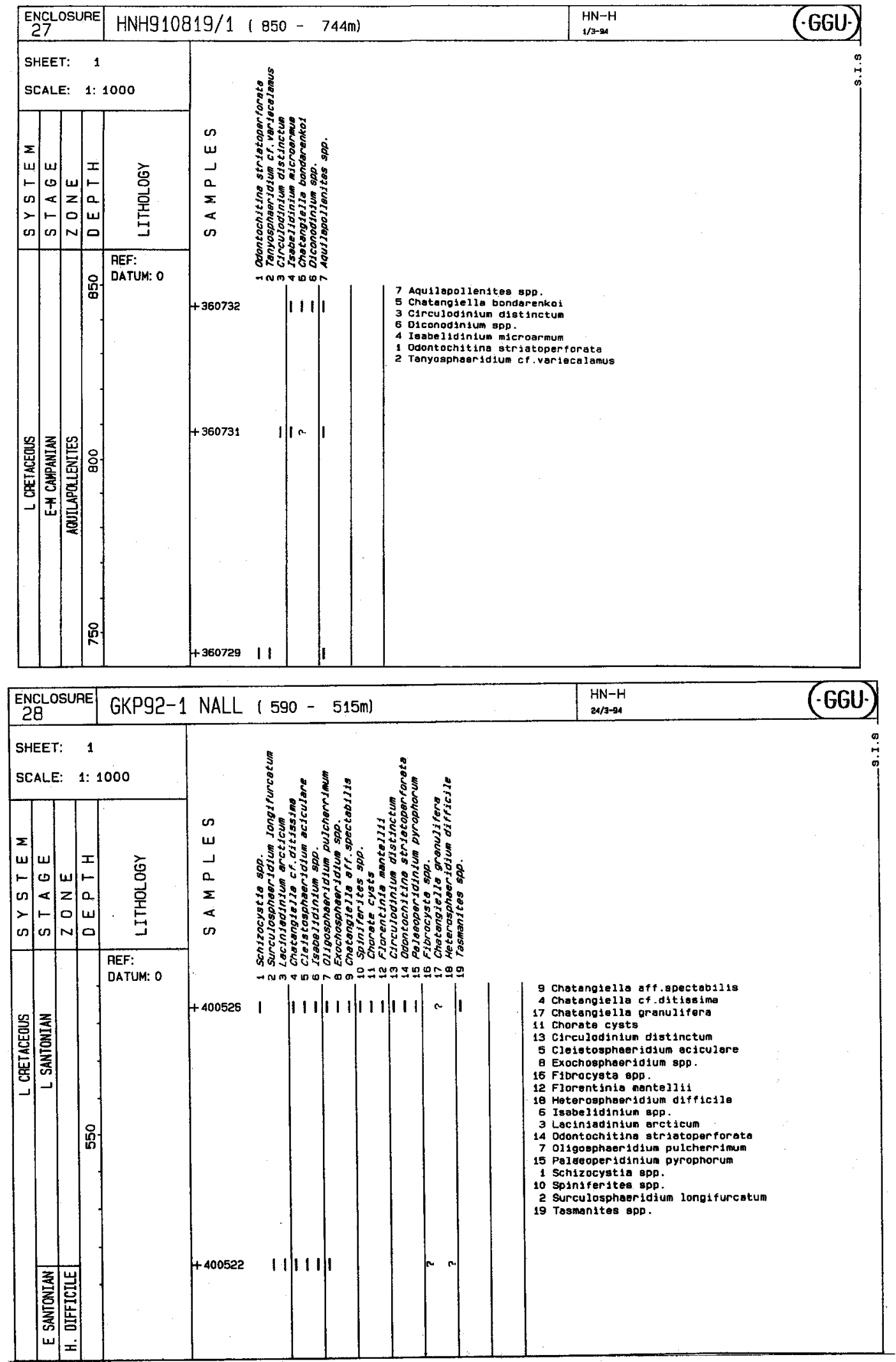


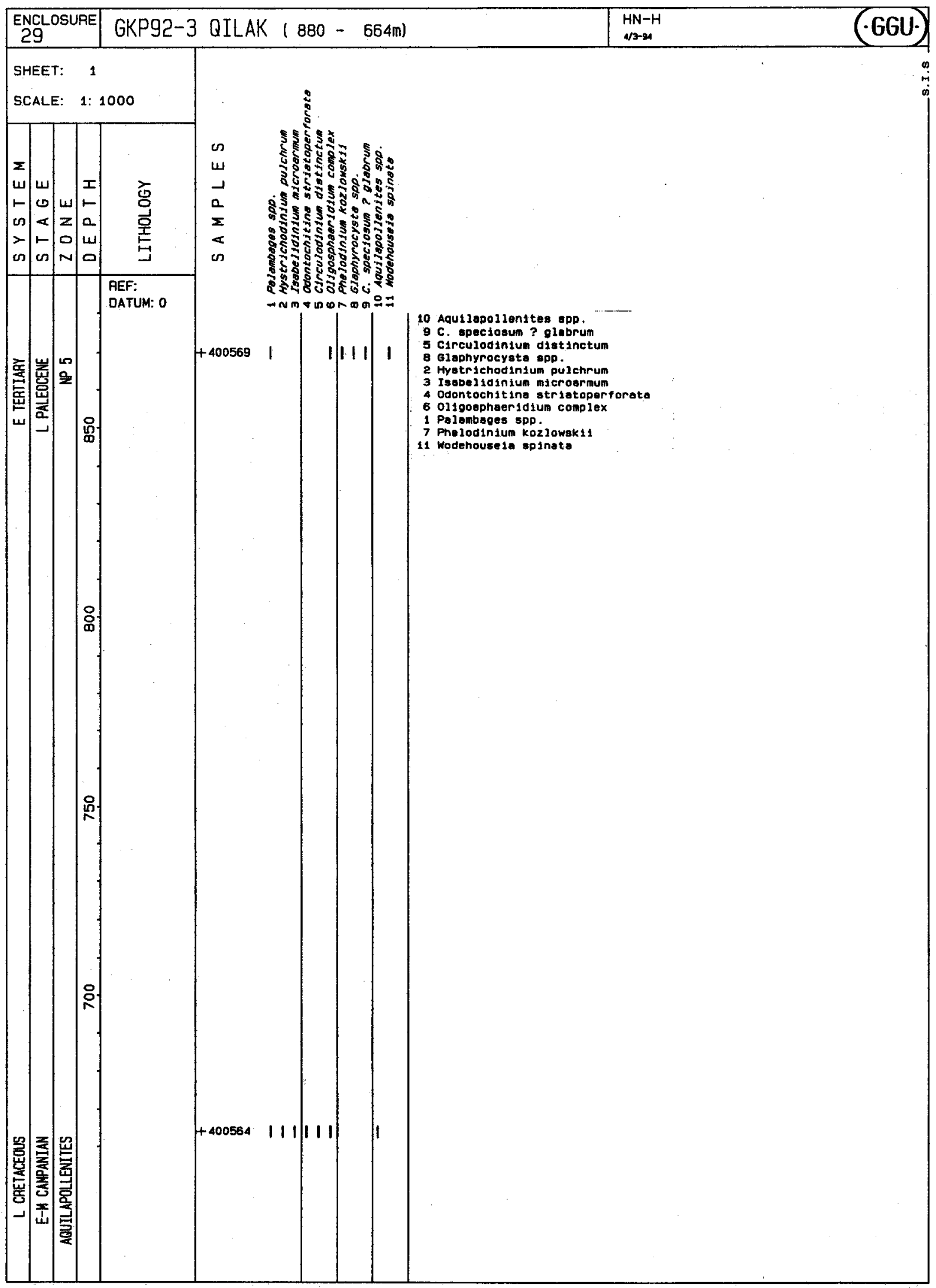




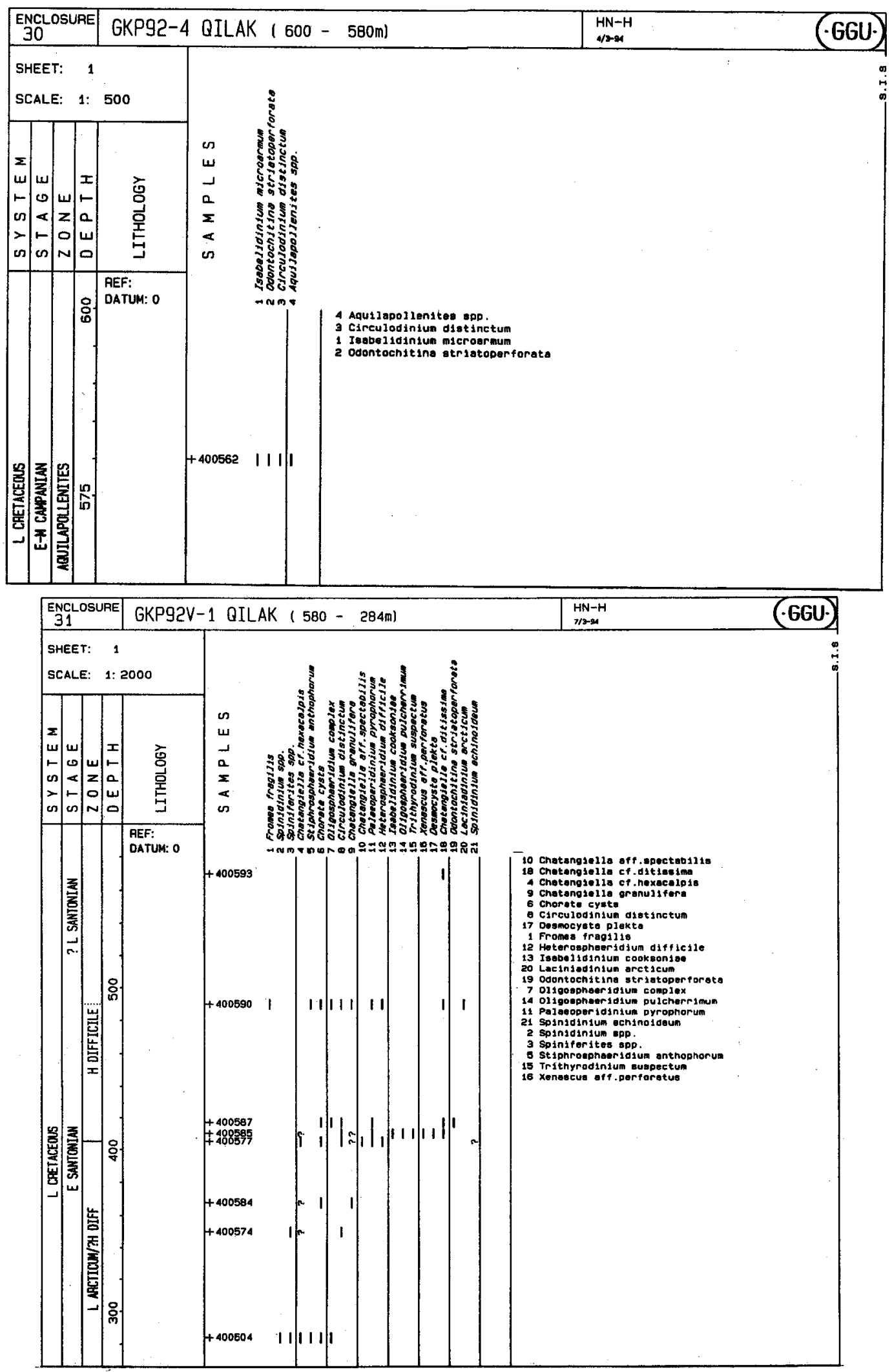




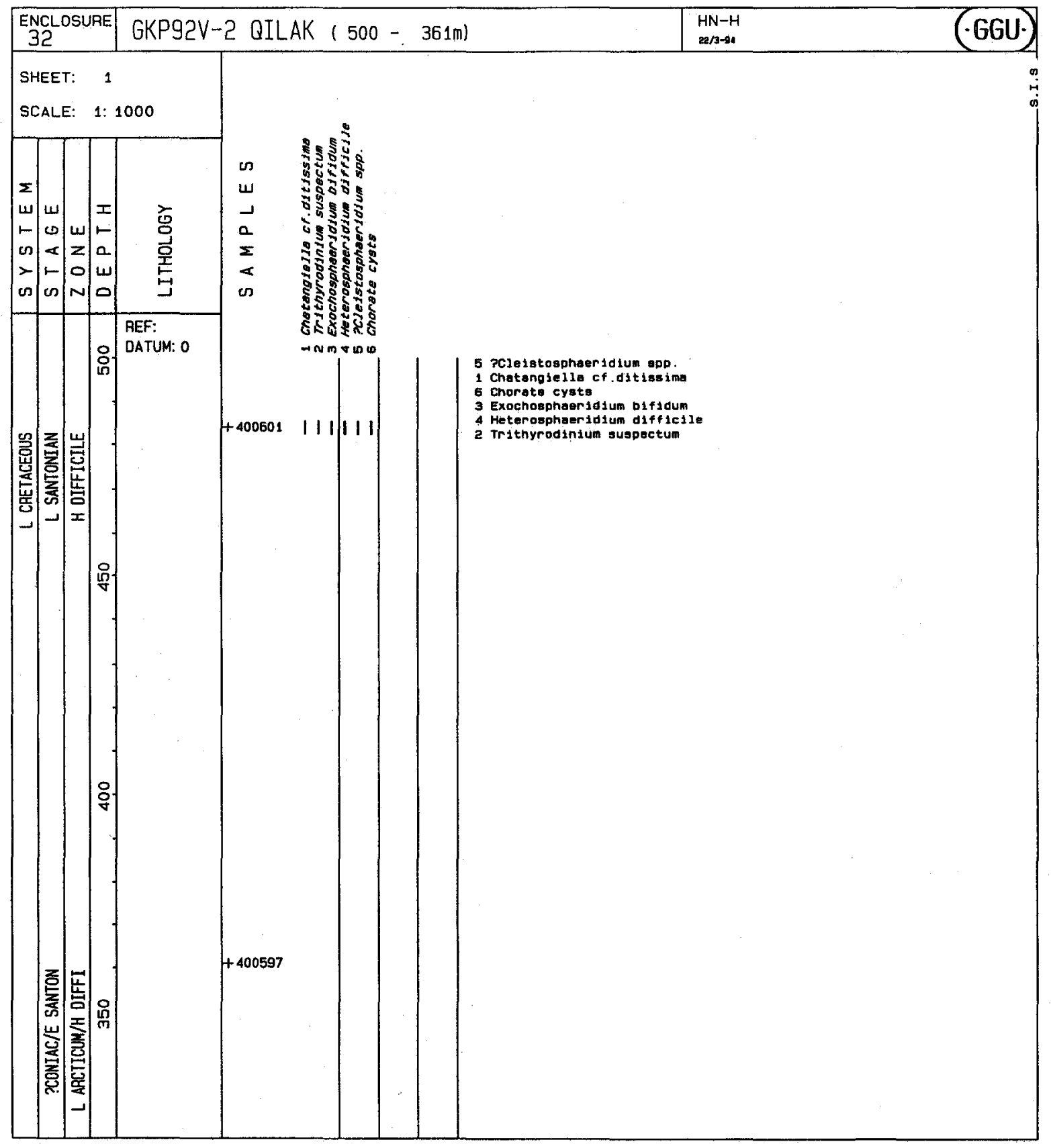

Enclosure 33 in pocket 


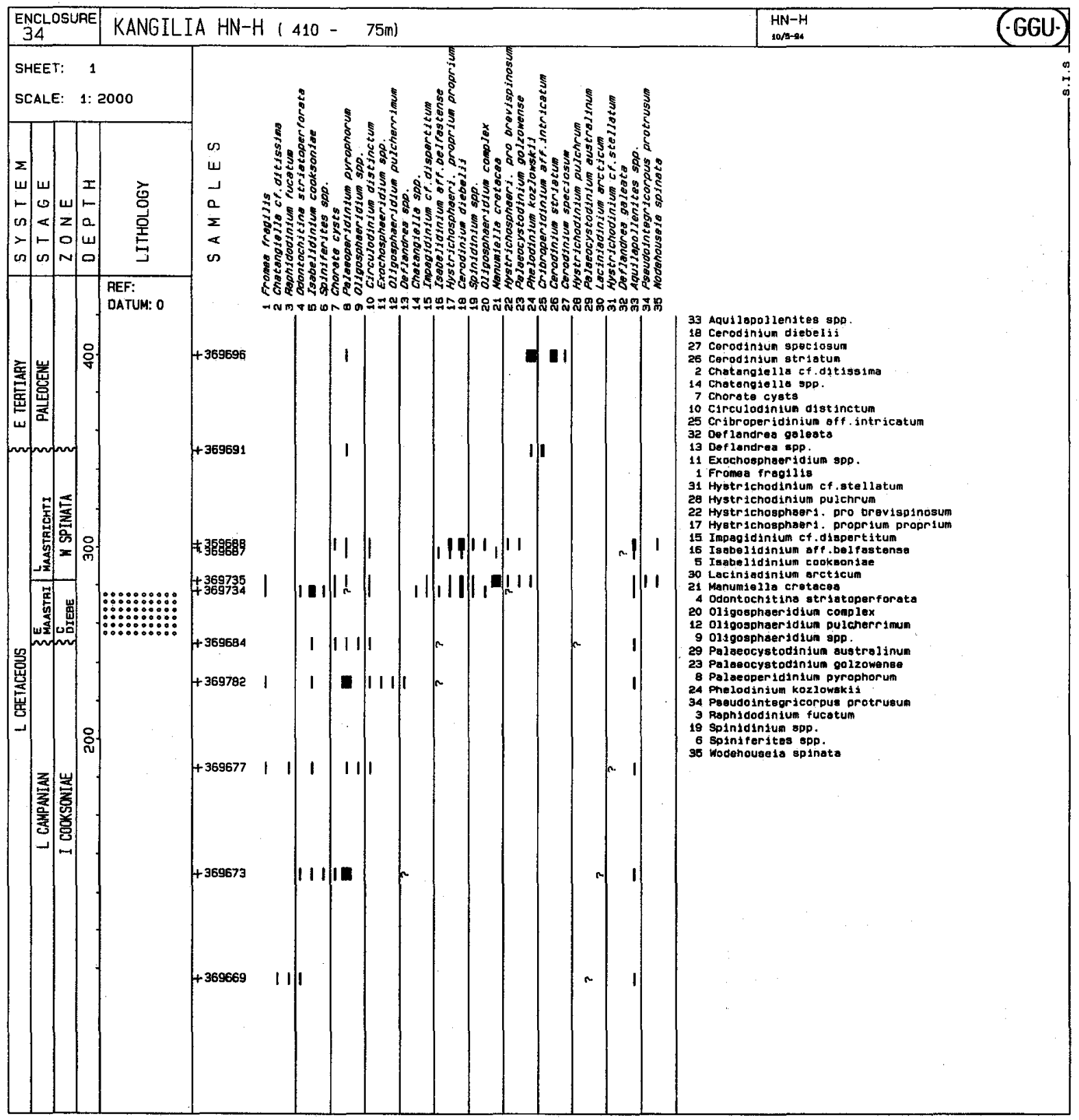

\section{Mudstone}

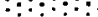

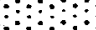

Medium to coarse grained sandstone 


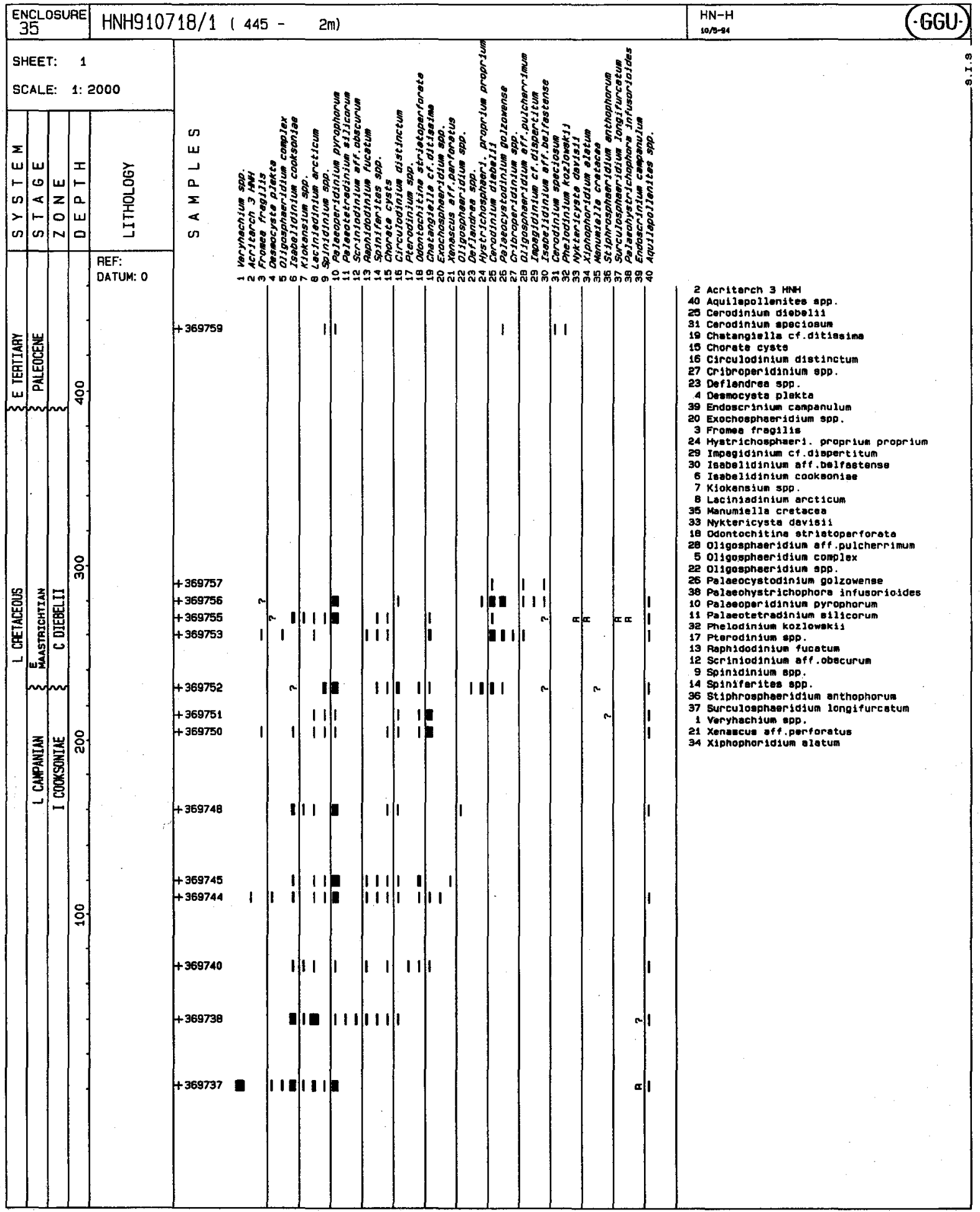




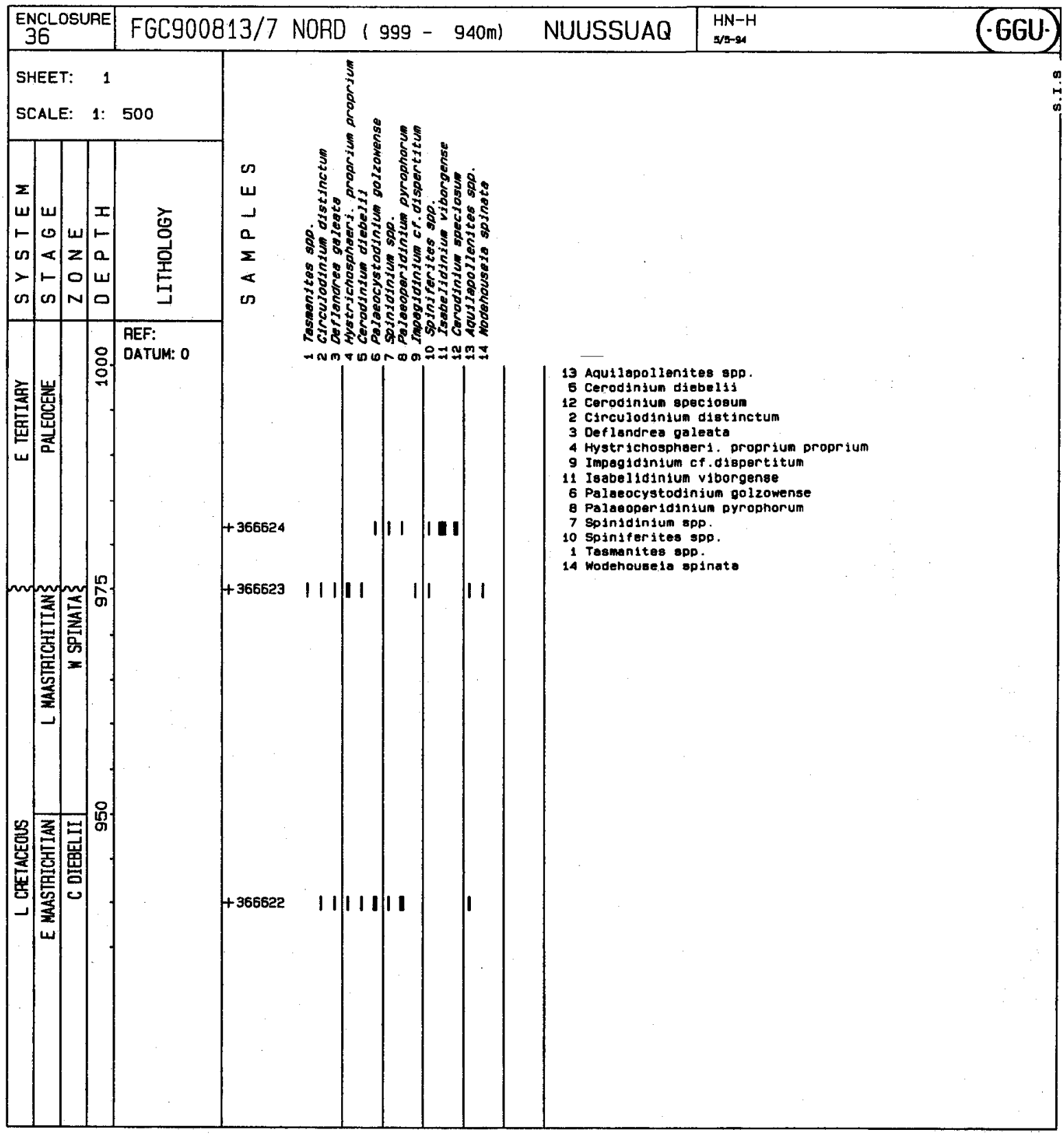




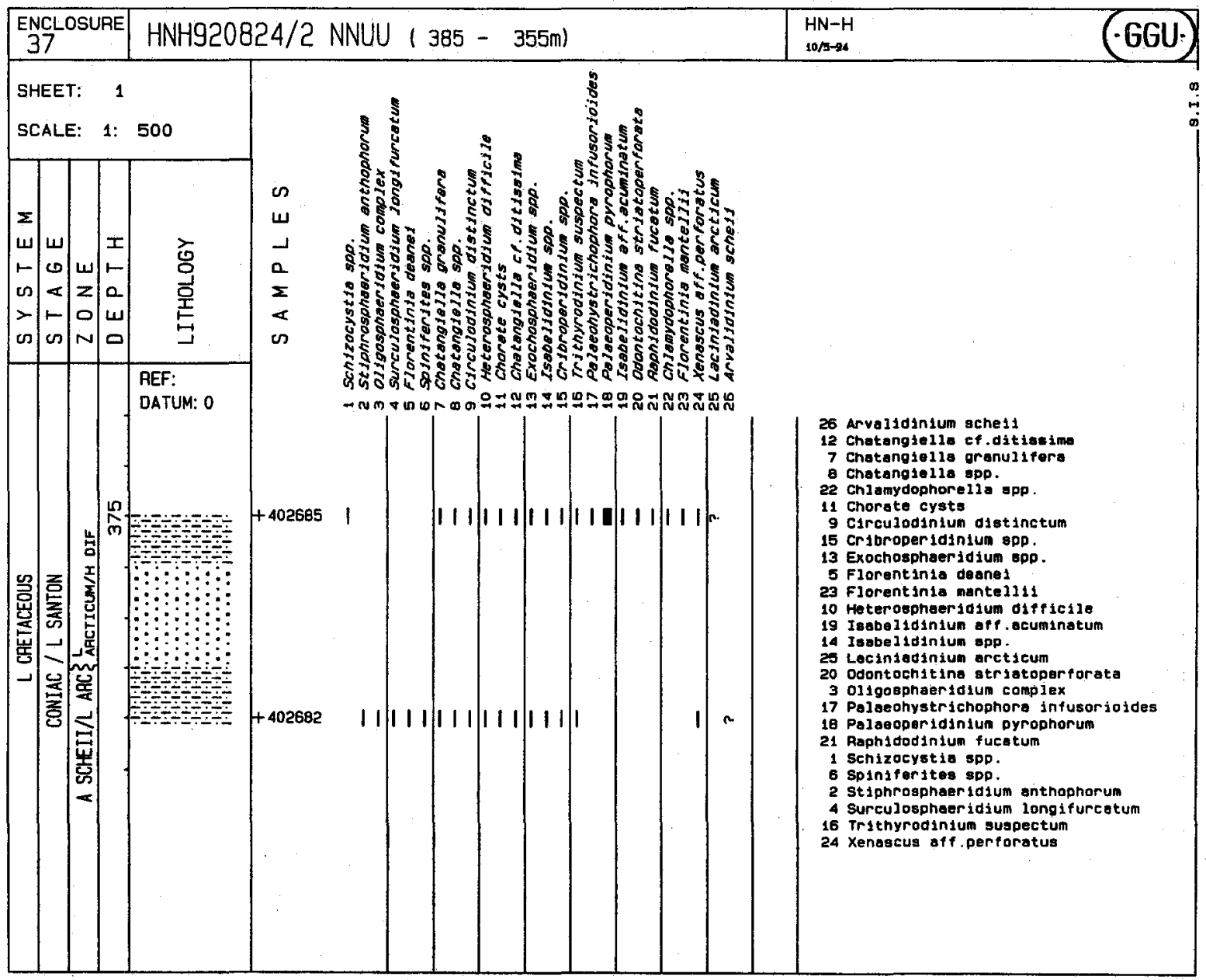




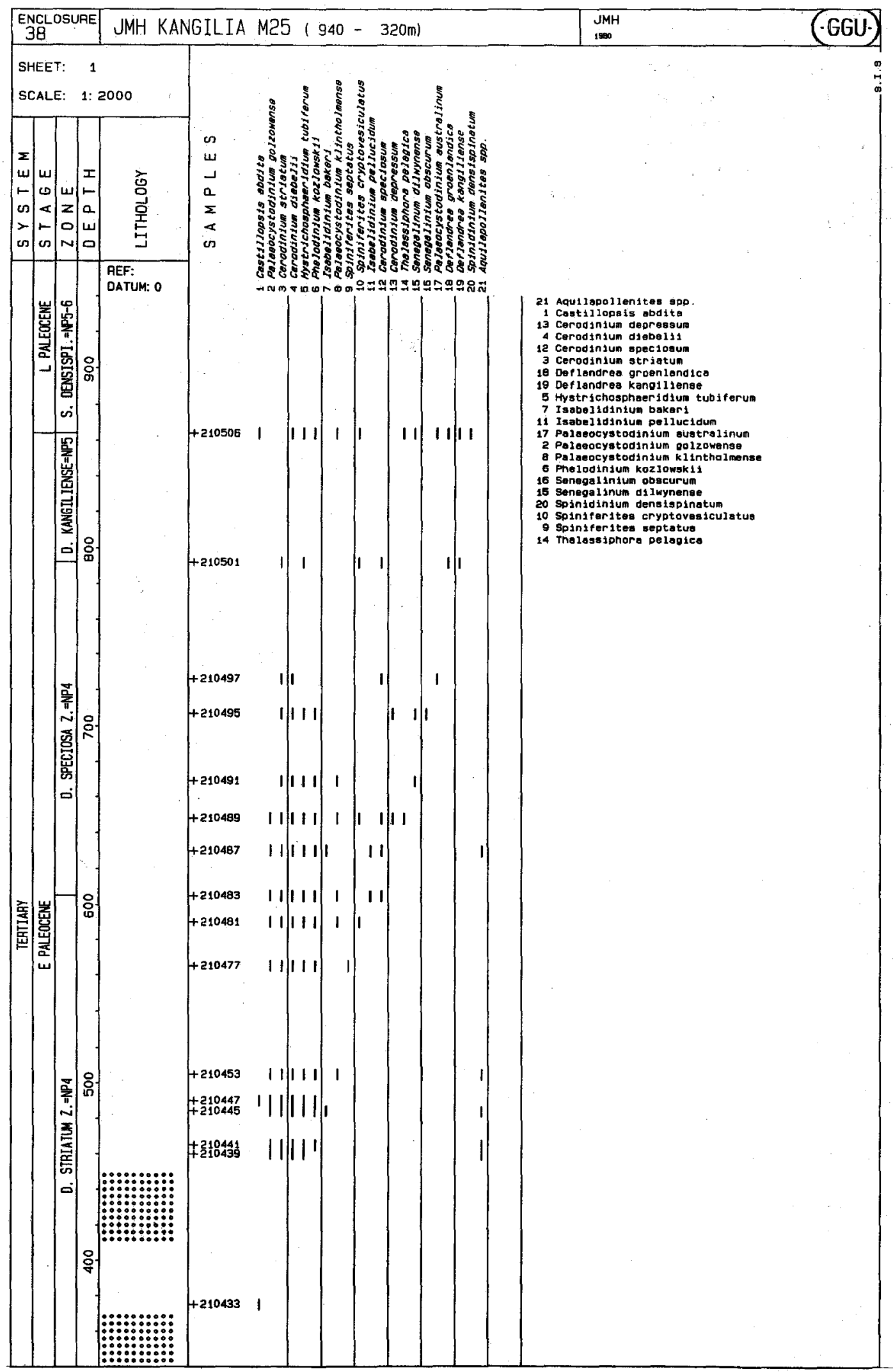


Plate 1. Svartenhuk

Fig. 1. Arvalidinium scheii, GGU 400711-12-4, 45.6-107.3; LVR 1.1352; MI 851; MGUH 23769.

Fig. 2. Arvalidinium scheii, GGU 400711-10-4, 22.1-94.7; LVR 1.1416; MI 902; MGUH 23770.

Fig. 3. Arvalidinium scheii, GGU 400712-15-4, 33.9-100.9; LVR 1.1661; MI 1119; MGUH 23771.

Fig. 4. Chatangiella granulifera, GGU 402680-4, HNH 920822/3; 51.2-97.0; LVR 1.1204; MI 722; MGUH 23772.

Fig. 5. Chatangiella granulifera, GGU 400709-26-3, 23.9-99.5; LVR 1.729; MI 408; MGUH 23773.

Fig. 6. Chatangiella granulifera, GGU 400709-26-3, 25.4-93.8; LVR 1.728; MI 407; MGUH 23774.

Fig. 7. Chatangiella sp. aff. C. granulifera, GGU 400709-14-3, 43.4-99.5; LVR 1.837; MI 509; MGUH 23775.

Fig. 8. Chatangiella verrucosa, GGU 400709-14-5, 29.6-94.8; LVR 1.829; MI 502; MGUH 23776.

Fig. 9. Chatangiella verrucosa, GGU 400709-26-3, 53.7-107.0; LVR 1.726; MI 405; MGUH 23777.

Fig. 10. Chatangiella verrucosa, GGU 400712-25-4, 43.1-102.9; LVR 1.1788; MI 1241; MGUH 23778.

Fig. 11. Chatangiella sp. cf. C. ditissima, GGU 400711-10-4; 38.9-108.5; LVR 1.1424; MI 907; MGUH 23779.

Fig. 12. Chatangiella sp. cf. C. ditissima, GGU 400712-25-3; 52.1-105.0; LVR 1.1792; MI 1245; MGUH 23780. 

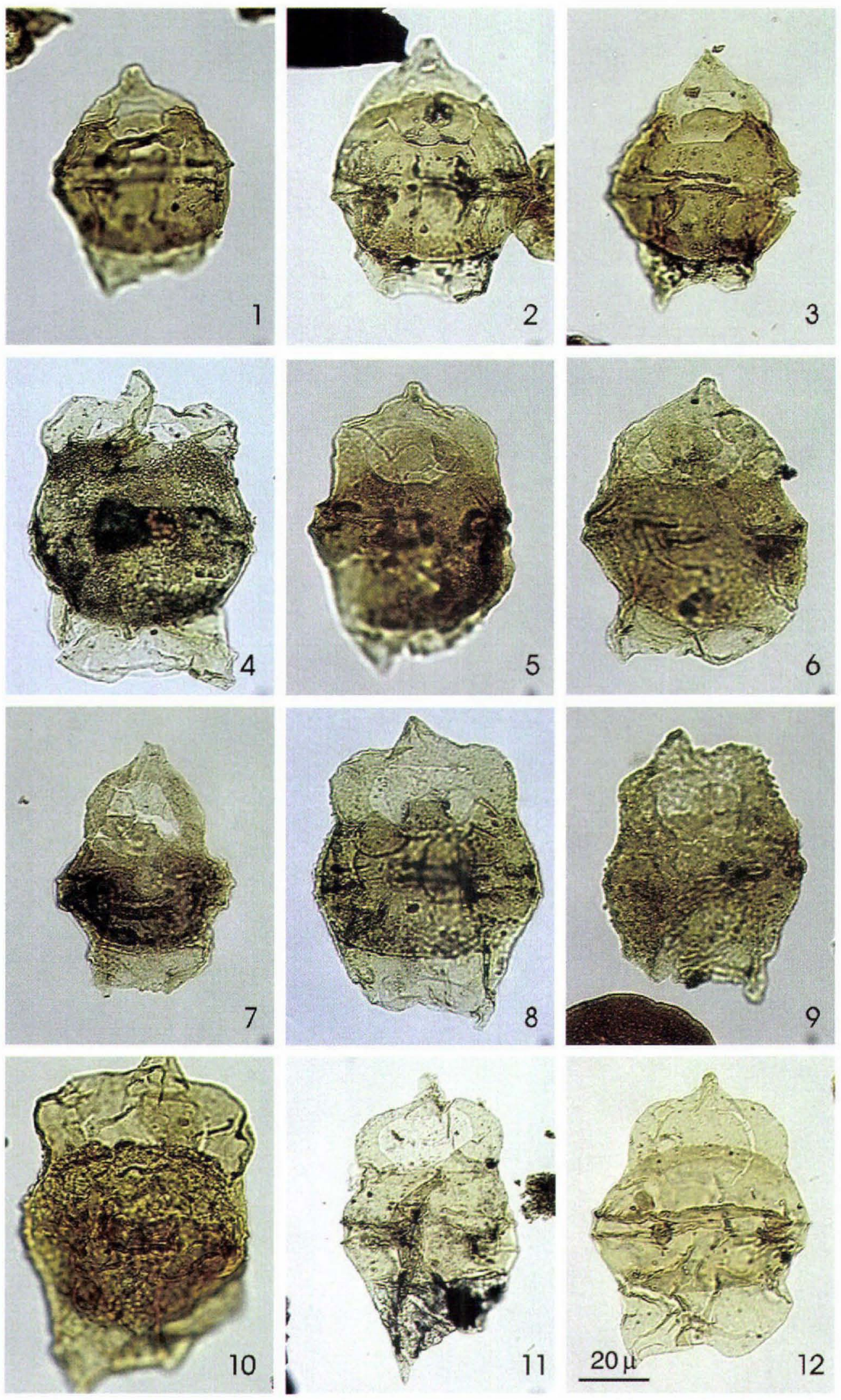
Plate 2. Svartenhuk

Fig. 1. Chatangiella sp. cf. C. madura, GGU 400709-26-3; 46.9-102.5; LVR 1.724; MI 404; MGUH 23781.

Fig. 2. Chatangiella sp. cf. C. madura, GGU 400709-26-3; 53.7-107.0; LVR 1.725; MI 405; MGUH 23782.

Fig. 3. Chatangiella sp. cf. C. madura, GGU 400709-12-3; 48.5-96.0; LVR 1.842; MI 514; MGUH 23783.

Fig. 4. Chatangiella mcintyrei sp. nov. holotype, GGU 400711-10-7; 35.3-96.6; LVR 1.5706; MI 4344; MGUH 23784.

Fig. 5. Chatangiella mcintyrei sp. nov., GGU 400712-24-3; 34.2-103.1; LVR 1.1765; MI 1218; MGUH 23785.

Fig. 6. Chatangiella mcintyrei sp. nov., GGU 400712-23-3; 38.8-95.1; LVR 1.1732; MI 1188; MGUH 23786.

Fig. 7. Chatangiella mcintyrei sp. nov., GGU 400711-6-7; 29.0-101.6; LVR 1.1502; MI 979; MGUH 23787.

Fig. 8. Chatangiella mcintyrei sp. nov., GGU 400712-14-4; 47.8-98.0; LVR 1.1634; MI 1092; MGUH 23788.

Fig. 9. Chatangiella mcintyrei sp. nov., GGU 402664-7, 400712; 52.1-103.0; LVR 1.1618; MI 1077; MGUH 23789.

Fig. 10. Chatangiella sp. aff. C. spectabilis, GGU 400711-10-4; 29.6-105.0; LVR 1.1427; MI 910; MGUH 23790.

Fig. 11. Chatangiella sp. aff. C. spectabilis, GGU 400712-25-3; 37.6-101,3; LVR 1.1790; MI 1243; MGUH 23791.

Fig. 12. Chatangiella sp. aff. C. spectabilis, GGU 400711-8-4; 44,7-102.7; LVR 1.1457; MI 937; MGUH 23792. 

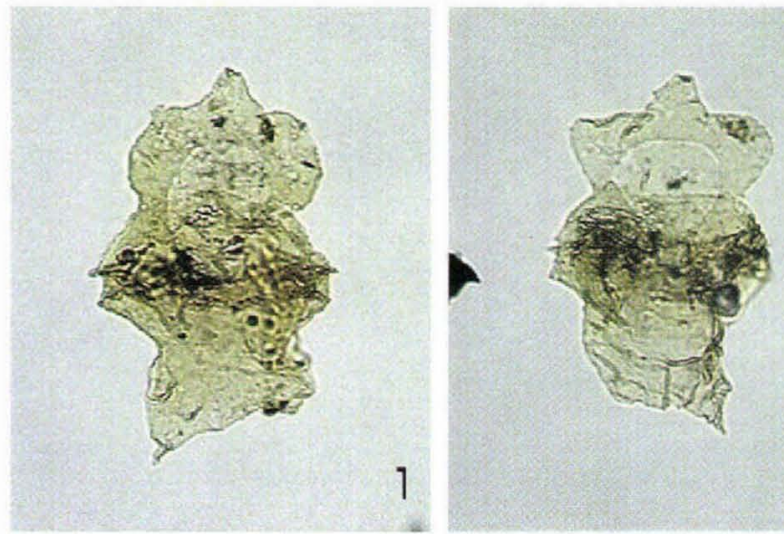

2
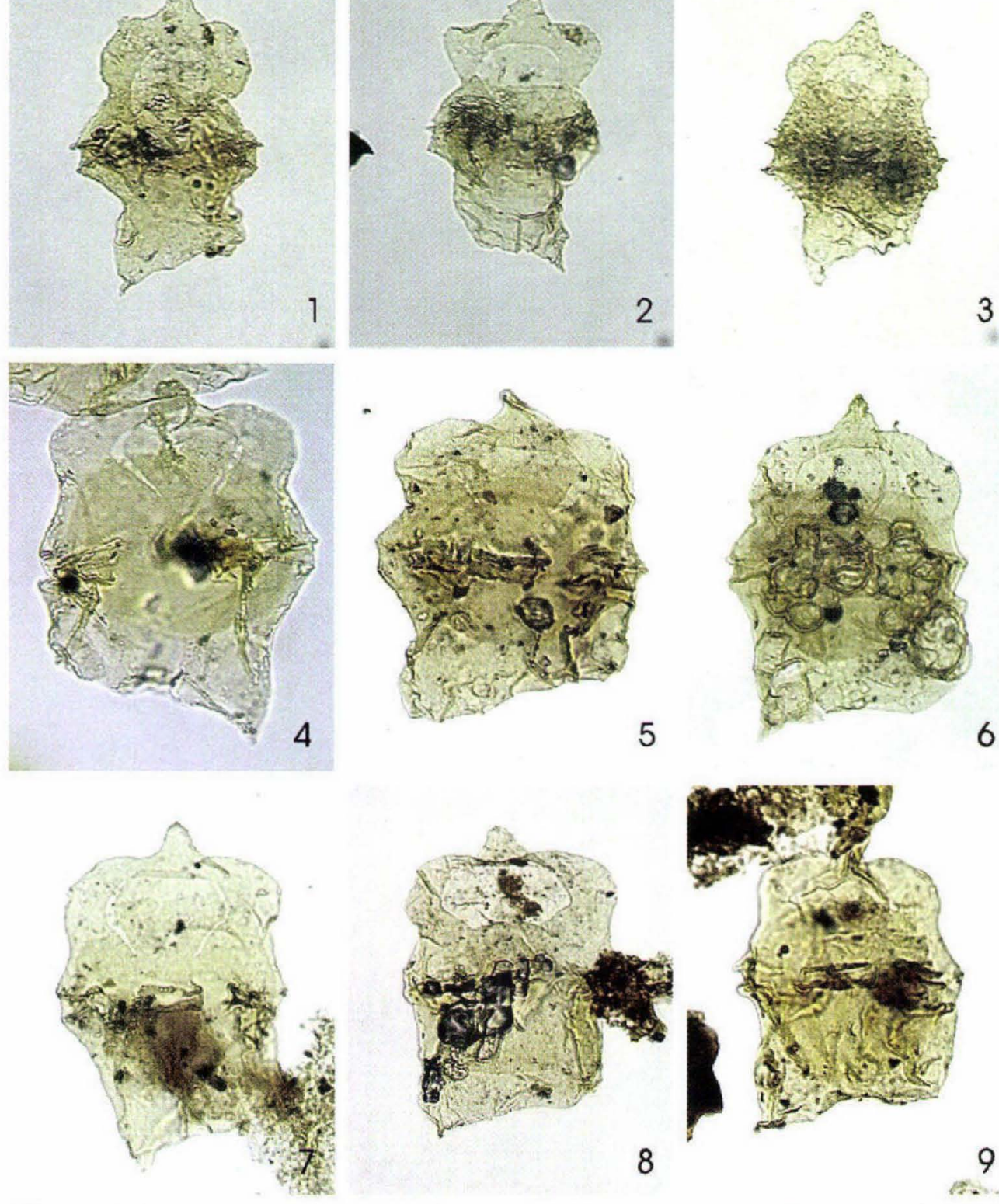

8
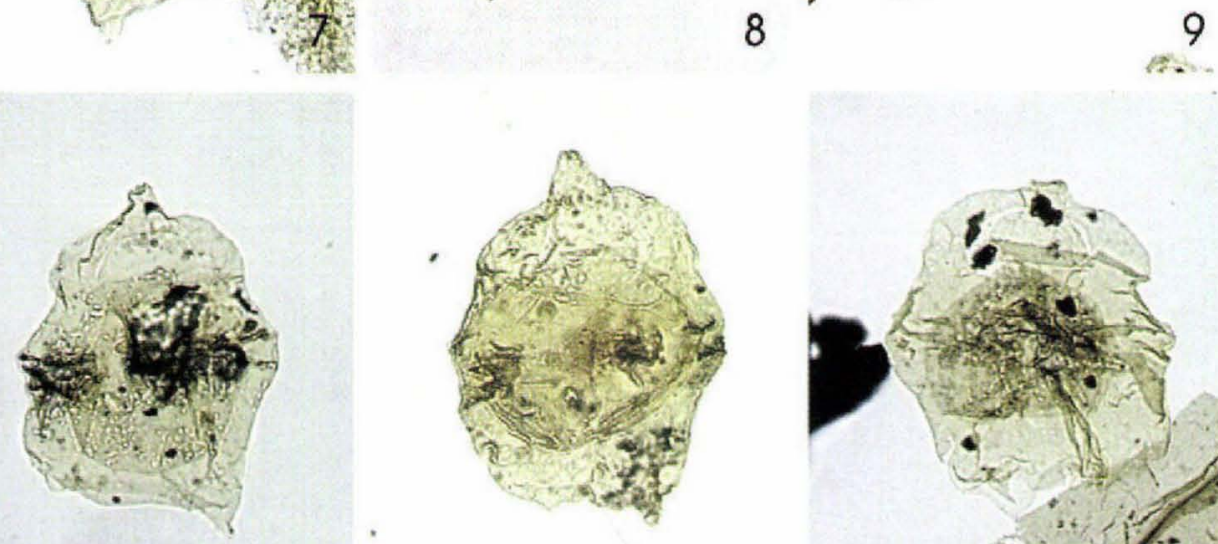

10

$1120 \mu=x / 12$ 
Plate 3. Svartenhuk

Fig. 1. Isabelidinium sp. 7 HNH, GGU 400709-22-3; 31.3-99.5; LVR 1.775; MI 451; MGUH 23793.

Fig. 2. Isabelidinium sp. 7 HNH, GGU 400709-12-3; 34.8-97.6; LVR 1.1126; MI 646; MGUH 23794.

Fig. 3. Isabelidinium sp. 7 HNH, GGU 400711-12-4; 50.3-103.0; LVR 1.1365; MI 861; MGUH 23795.

Fig. 4. Isabelidinium sp. aff. I. acuminatum, GGU 251506-,7 JGL; 26.1-103.0; LVR 1.701; MI 384; MGUH 23796.

Fig. 5. Isabelidinium sp. aff. I. acuminatum, GGU 251506-,7 JGL; 50.6-106.8; LVR 1.702; MI 385; MGUH 23797.

Fig. 6. Isabelidinium sp. aff. I. acuminatum, GGU 251507-,4 JGL; 22.6-106.3; LVR 1.707; MI 389; MGUH 23798.

Fig. 7. Isabelidinium svartenhukensis sp. nov. holotype, GGU 400712-26-4; 26.6-97.0; LVR 1824; MI 1274; MGUH 23799.

Fig. 8. Isabelidinium svartenhukensis sp. nov., GGU 400712-26-4; 46.1-103.9; LVR 1.1825; MI 1275; MGUH 23800.

Fig. 9. Isabelidinium svartenhukensis sp. nov., GGU 400712-11-8; 36,9-99.2; LVR 1.1866; MI 1316; MGUH 23801.

Fig. 10. Isabelidinium svartenhukensis sp. nov., GGU 400712-15-4; 28,9-106.4; LVR 1.1664; MI 1122; MGUH 23802.

Fig. 11. Isabelidinium svartenhukensis sp. nov., paratype, GGU 400712-15-4; 35,5-102.1; LVR 1.1666; MI 1124; MGUH 23803.

Fig. 12. Isabelidinium svartenhukensis sp. nov., GGU 400712-15-4; 45,0-104.3; LVR 1.1667; MI 1125; MGUH 23804. 

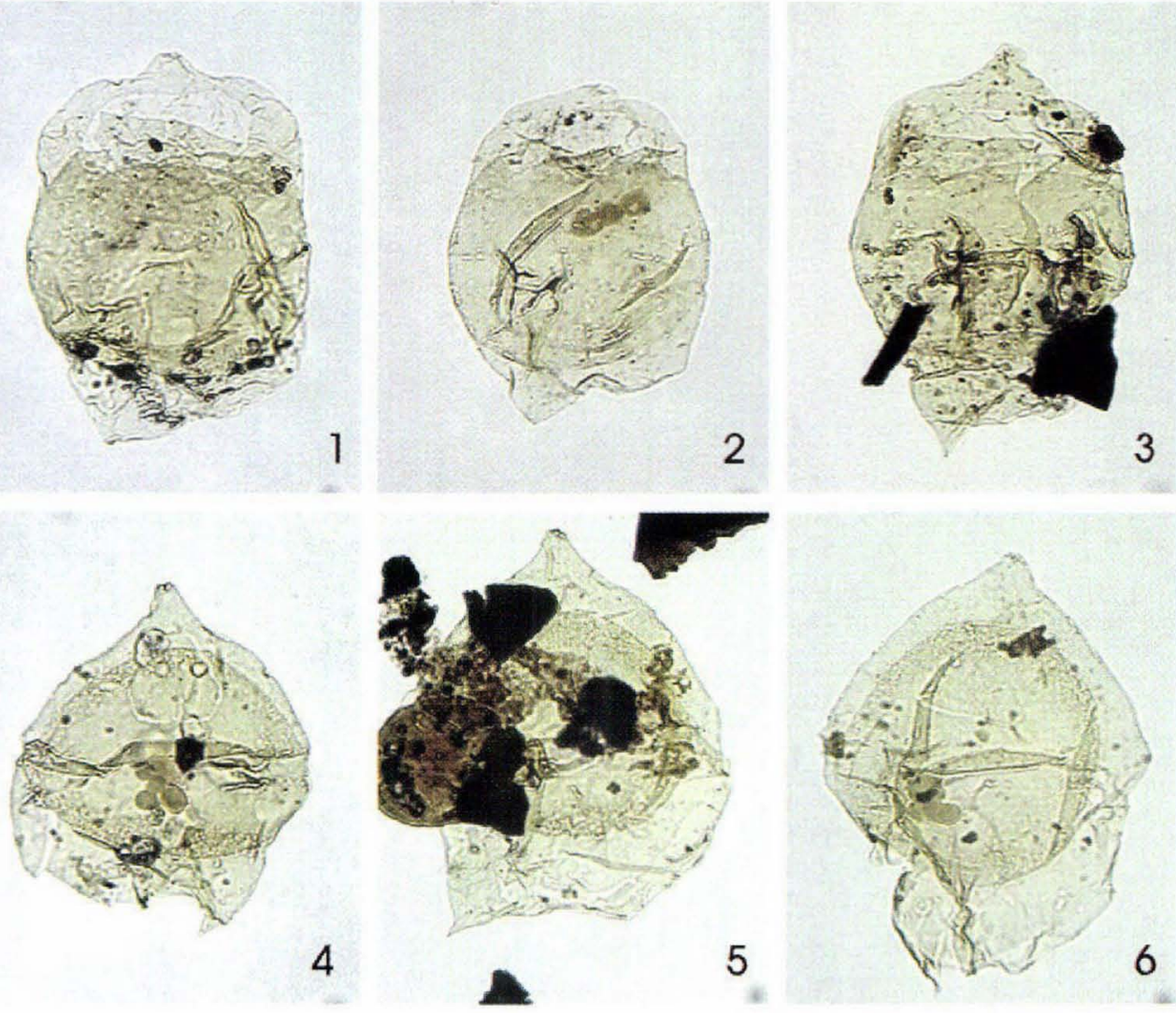

4
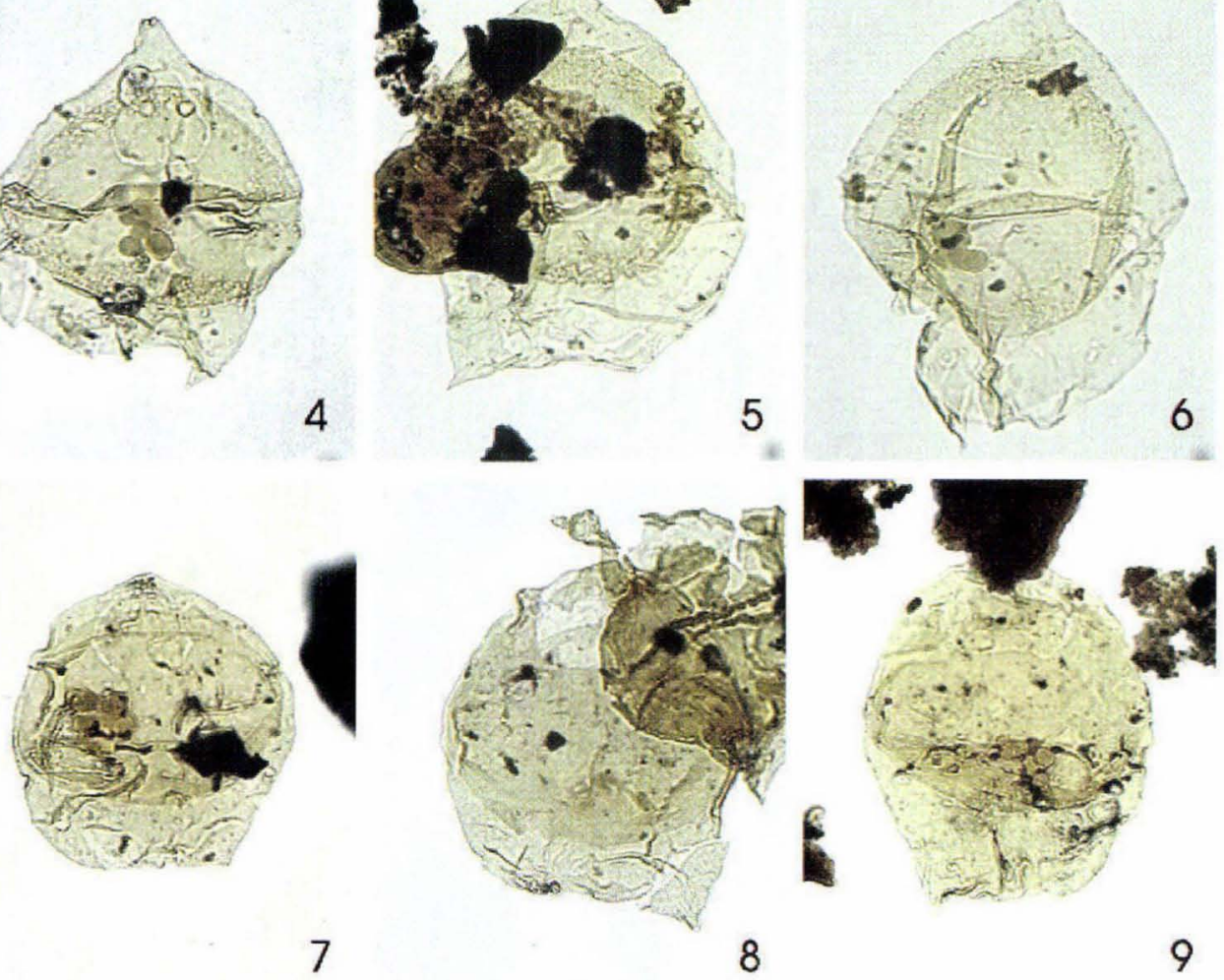

7

8

9

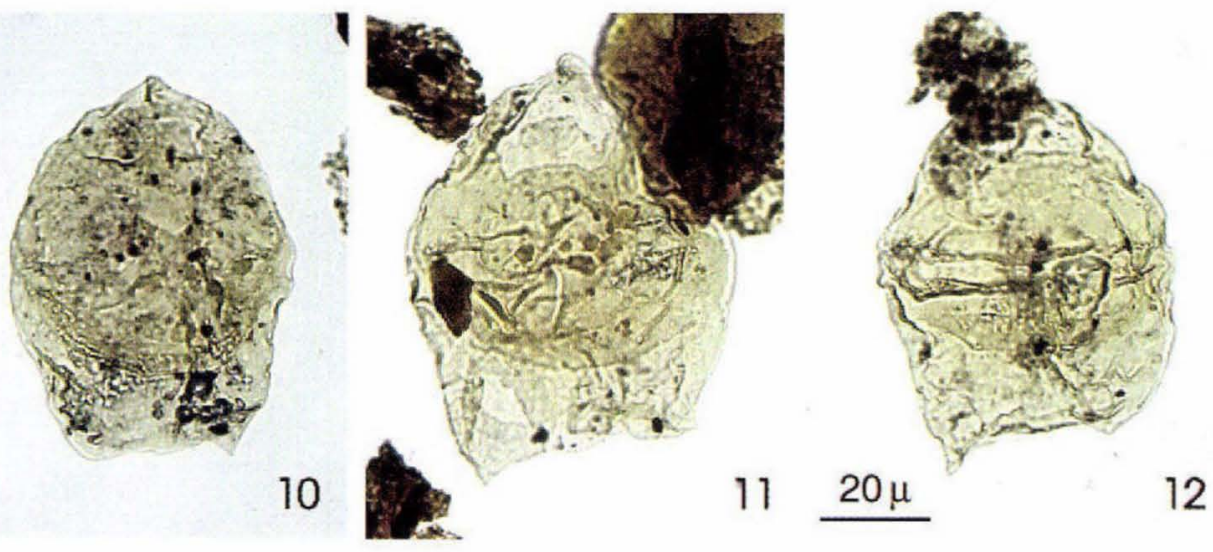


Plate 4. Svartenhuk

Fig. 1. Laciniadinium arcticum, GGU 400711-8-4; 53.8-95.6; LVR 1.1458; MI 938; MGUH 23805.

Fig. 2. Spinidinium echinoideum, GGU 400712-26-3; 28.8-98.0; LVR 1.1836; MI 1286; MGUH 23806.

Fig. 3. Spinidinium echinoideum, GGU 400710-15-4; 30.8-106.0; LVR 1.1521; MI 994; MGUH 23807.

Fig. 4. Spinidinium echinoideum, GGU 400712-14-4; 52.9-109.4; LVR 1.1647; MI 1105; MGUH 23808.

Fig. 5. Spinidinium echinoideum, with very reduced echinae, GGU 400712-25-4; 51.2-98.9; LVR 1.1814; MI 1266; MGUH 23809.

Fig. 6. Spinidinium echinoideum, with very reduced echinae, GGU 400712-11-4; 18.3-110.0; LVR 1.1851; MI 1301; MGUH 23810.

Fig. 7. Cribroperidinium sp. aff. C. intricatum, GGU 400709-20-3; 22.7-103.8; LVR 1.786; MI 462; MGUH 23811.

Fig. 8. Dinopterygiumm cladoides, GGU 400709-24-3; 30.5-108.7; LVR 1.760; MI 437; MGUH 23812.

Fig. 9. Dinopterygiumm cladoides, GGU 400711-8-4; 50.8-95.6; LVR 1.1472; MI 951; MGUH 23813.

Fig. 10. Palaeohystrichodinium infusorioides, GGU 400709-24-3; 30.6-99.0; LVR 1.750; MI 427; MGUH 23814.

Fig. 11. Endoscrinium campanula, GGU 402664-8, 400712; 26.0-105.8; LVR 1.1620; MI 1079; MGUH 23815.

Fig. 12. Scriniodinium? sp., GGU 402680-7, HNH 920822/5; 53.8-98.6; LVR 1.1222; MI 740; MGUH 23816. 

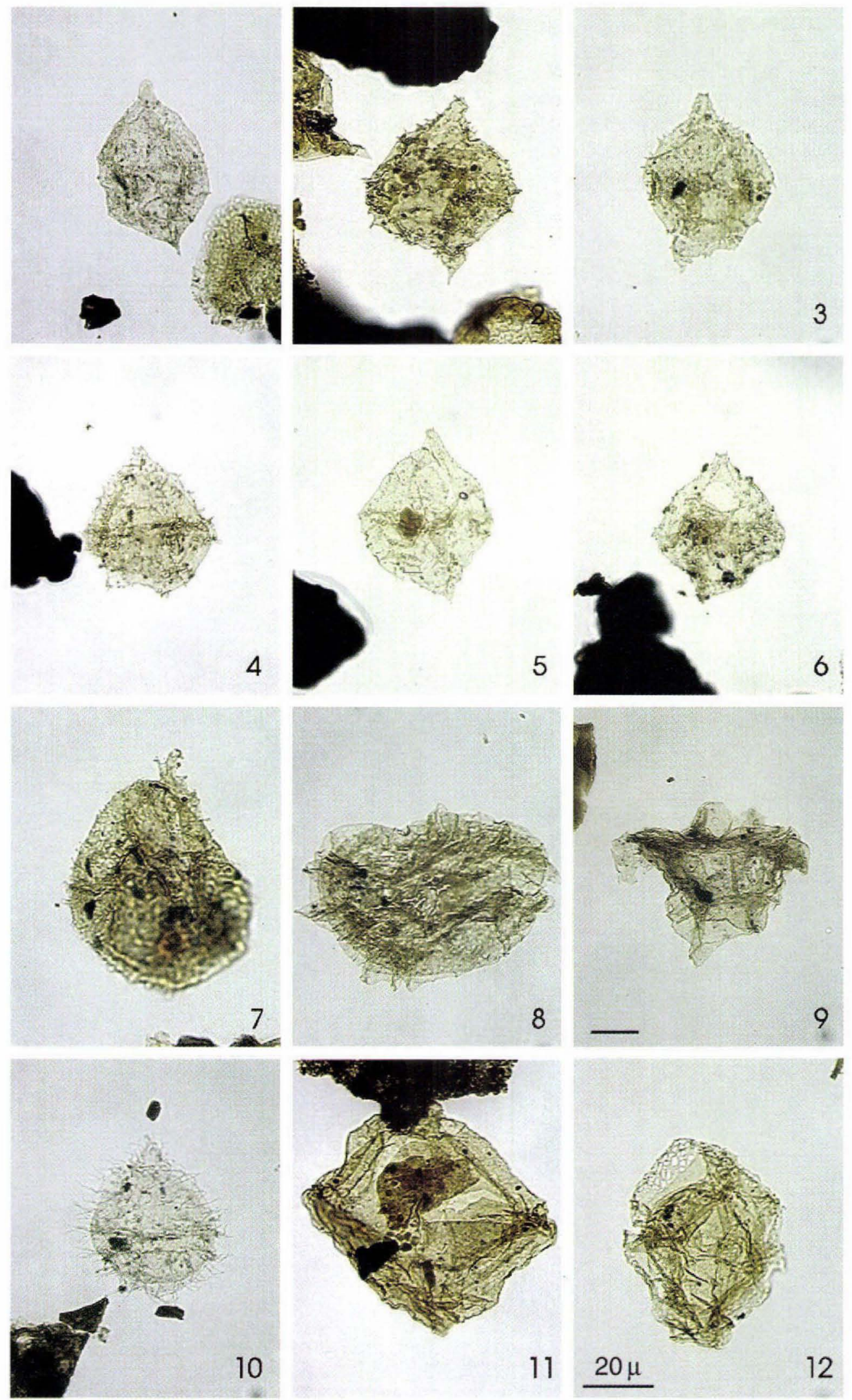
Plate 5. Svartenhuk

Fig. 1. Scriniodinium? sp. aff. S. obscurum/C. grossa, GGU 400709-12-5; 37.6-101.2; LVR 1.1128; MI 648; MGUH 23817.

Fig. 2. Scriniodinium? sp. aff. S. obscurum/C. grossa, GGU 400712-15-4; 40.0-104.5; LVR 1.1678; MI 1136; MGUH 23818.

Fig. 3. Scriniodinium? sp. aff. S. obscurum/C. grossa, GGU 400712-26-3; 32.0-109.0; LVR 1.2204, MI 1566; MGUH 23819.

Fig. 4. Chlamydophorella? sp. aff. C. grossa, GGU 400712-25-4; 44.1-107.0; LVR 1.1803; MI 1256; MGUH 23820.

Fig. 5. Odonthochitina striatoperforata, GGU 400709-10-4, 42.8-107.3; LVR 1.1151; MI 669; MGUH 23821.

Fig. 6. Odonthochitina striatoperforata, GGU 400711-8-4, 47.9-108.0; LVR 1.1463; MI 943; MGUH 23822.

Fig. 7. Odonthochitina striatoperforata, GGU 400712-17-4, 35.6-94.5; LVR 1.1715; MI 1171; MGUH 23823.

Fig. 8. Odonthochitina striatoperforata, GGU 400712-25-4, 31.1-111.9; LVR 1.1800; MI 1253; MGUH 23824.

Fig. 9. Xenascus sp. aff. X. perforatus, GGU 400711-6-4, 49.5-109.0; LVR 1.1481; MI 959; MGUH 23825.

Fig. 10. Xenascus sp. aff. X. perforatus, GGU 400711-12-3, 47.8-109.7; LVR 1.1376; MI 869; MGUH 23826.

Fig. 11. Xenascus sp. aff. X. perforatus, GGU 400711-12-3, 56.2-101.9; LVR 1.1377; MI 870; MGUH 23827.

Fig. 12. Xenascus sp. aff. $X$. perforatus, GGU 402664-8, 400712, 46.8-103.4; LVR 1.1621; MI 1080; MGUH 23828. 


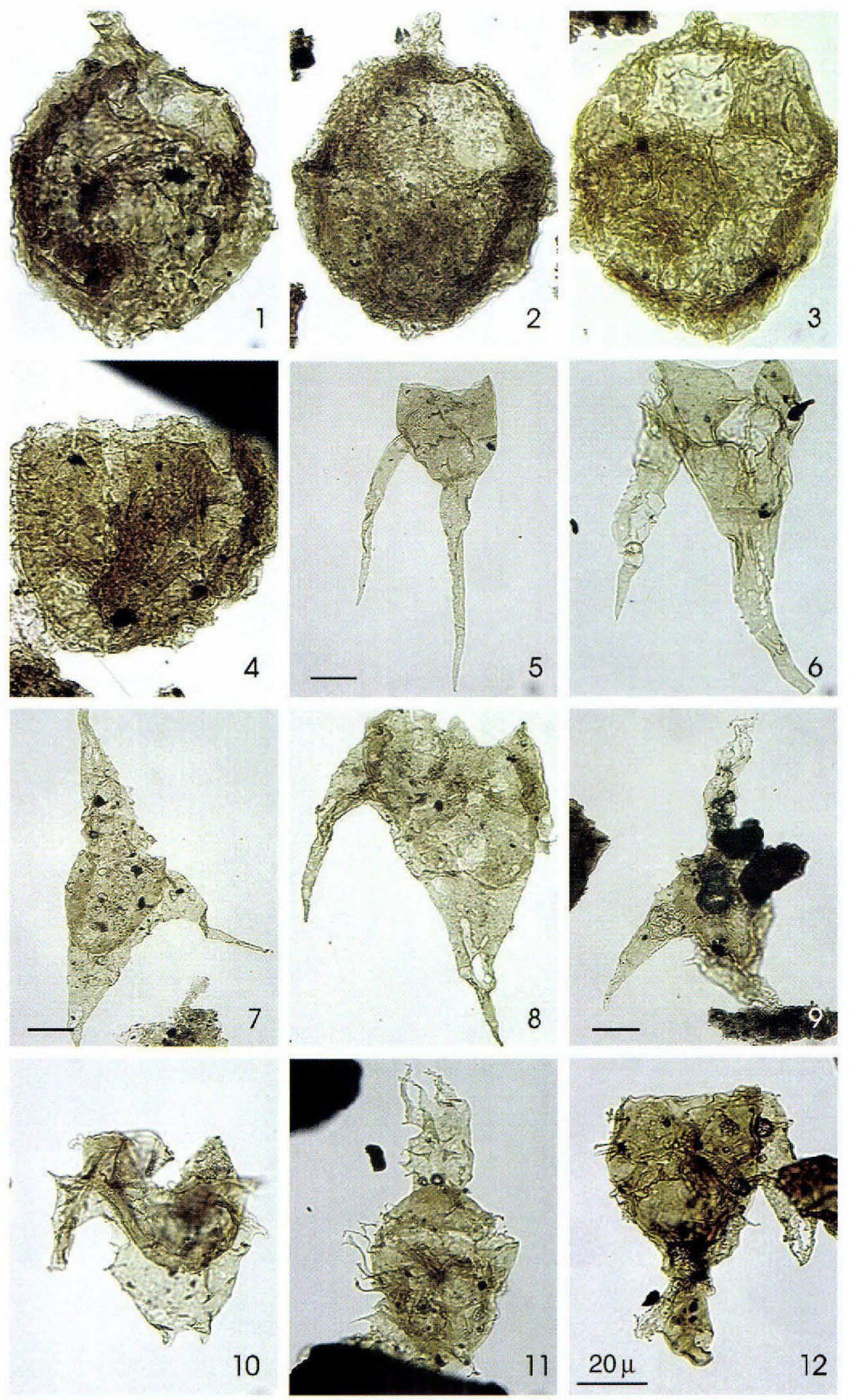


Plate 6. Svartenhuk

Fig. 1. Microdinium reticulatum 402664-9, 400712; 48.3-110.3; LVR 1.1626; MI 799; MGUH 23829.

Fig. 2. Trithyrodinium suspectum, GGU 402680-7, HNH 920822/5; 46.9-107.3; LVR 1.1221; MI 739; MGUH 23830.

Fig. 3. Trithyrodinium suspectum, GGU 400712-23-3; 31.5-100.6; LVR 1.1750; MI 1205; MGUH 23831.

Fig. 4. Trithyrodinium suspectum, GGU 400712-15-4; 41.8-96.0; LVR 1.1680; MI 1137; MGUH 23832.

Fig. 5. Trithyrodinium suspectum, GGU 400709-24-3; 36.9-104.5; LVR 1.752; MI 429; MGUH 23833.

Fig. 6. Trithyrodinium? sp., GGU 400712-14-4; 39.9-96.4; LVR 1.1650; MI 1108; MGUH 23834.

Fig. 7. Oligosphaeridium complex, GGU 400712-23-3, 32.4-101.7; LVR 1.1747; MI 1203; MGUH 23835.

Fig. 8. Oligosphaeridium complex, GGU 400711-12-4, 46.0-97.5; LVR 1.1407; MI 894; MGUH 23836.

Fig. 9. Oligosphaeridium sp. aff. O. pulcherrimum, GGU 400709-14-5, 41.2-106.0; LVR 1.831; MI 504; MGUH 23837.

Fig. 10. Oligosphaeridium sp. aff. O. pulcherrimum, GGU 400711-10-4, 44.8-111.9; LVR 1.1444; MI 926; MGUH 23838.

Fig. 11. Stiphrosphaeridium sp. aff. S. anthophorum, GGU 400711-12-4 44.3-106.4; LVR 1.1404; MI 892; MGUH 23839.

Fig. 12. Hystrichodinium pulchrum, GGU 400712-16-4, 30.6-112.9; LVR 1.1700; MI 1156; MGUH 23840. 


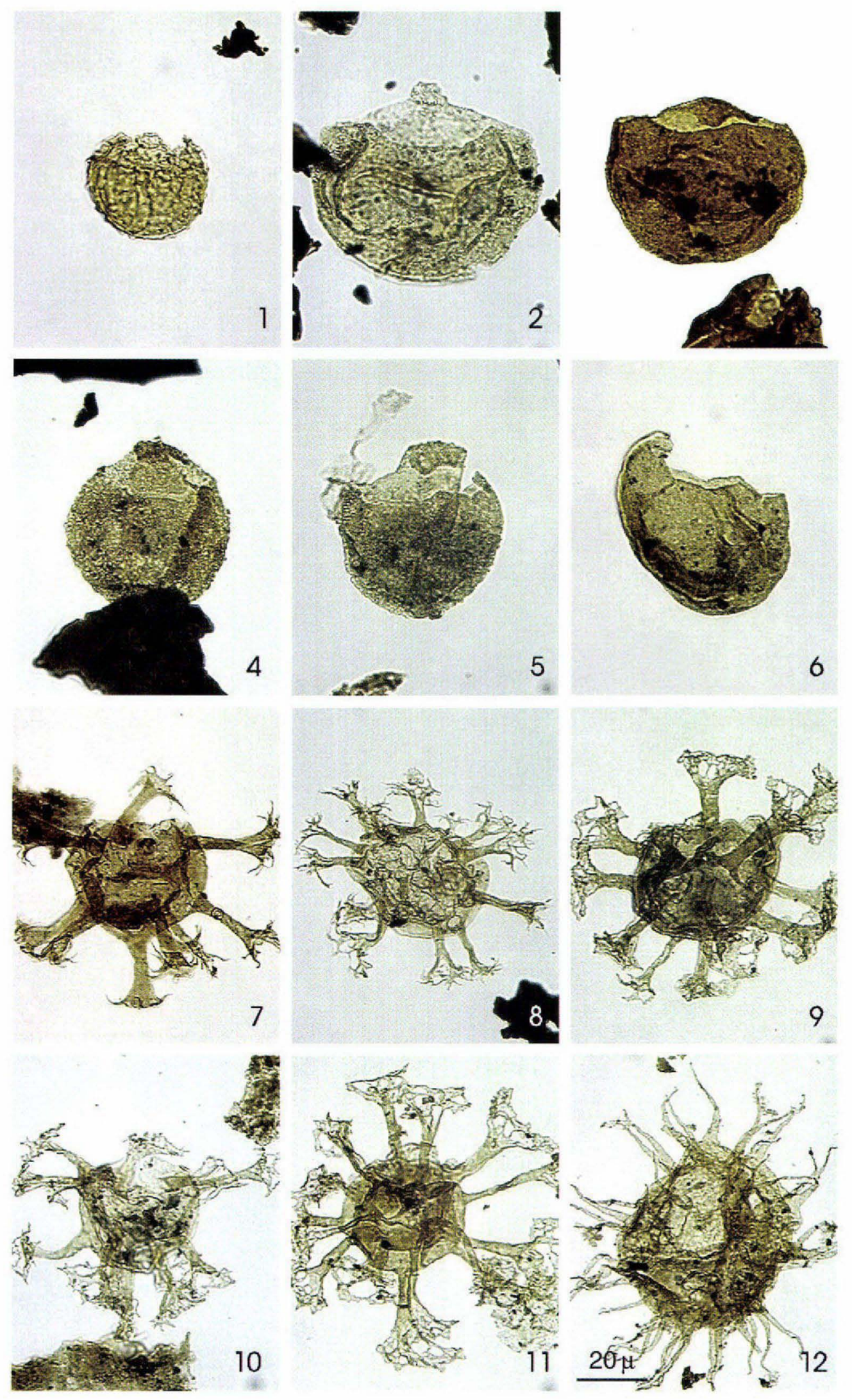


Plate 7. Svartenhuk

Fig. 1. Surculosphaeridium? longifurcatum, GGU 400709-16-3, 55.3-100.6; LVR 1.826; MI 499; MGUH 23841.

Fig. 2. Surculosphaeridium? longifurcatum, GGU 400709-18-3, 24.6-106.4; LVR 1.810; MI 484; MGUH 23842.

Fig. 3. Florentinia mantellii, GGU 400709-16-4; 37.8-99.5; LVR 1.828; MI 501; MGUH 23843.

Fig. 4. Florentinia deanei, GGU 400712-26-5; 42.9-108.2; LVR 1.2203; MI 1565; MGUH 23844.

Fig. 5. Florentinia deanei, GGU 400712-25-5; 42.9-105.9; LVR 1.2208; MI 1570; MGUH 23845.

Fig. 6. Florentinia mantellii, GGU 400711-12-4; 58.7-100.6; LVR 1.1401; MI 888; MGUH 23846.

Fig. 7. Florentinia mantellii, GGU 400711-12-7; 24.1-102.6; LVR 1.2780; MI 2067; MGUH 23847.

Fig. 8. Florentinia deanei, GGU 400711-8-8; 37.0-109.2; LVR 1.2788; MI 2075; MGUH 23848.

Fig. 9. Heterosphaeridium difficile, GGU 400711-14-4; 28.3-104.2; LVR 1.1319; MI 822; MGUH 23849.

Fig. 10. Heterosphaeridium difficile, operculum, GGU 402680-7, HNH 920822/5; 19.6-105.0; LVR 1.1195; MI 7132; MGUH 23850.

Fig. 11. Heterosphaeridium difficile, GGU 400710-15-7; 25.1-98.7; LVR 1.1522; MI 995; MGUH 23851.

Fig. 12. Heterosphaeridium difficile, GGU 400712-26-4; 48.1-106.2; LVR 1.1842; MI 1292; MGUH 23852. 

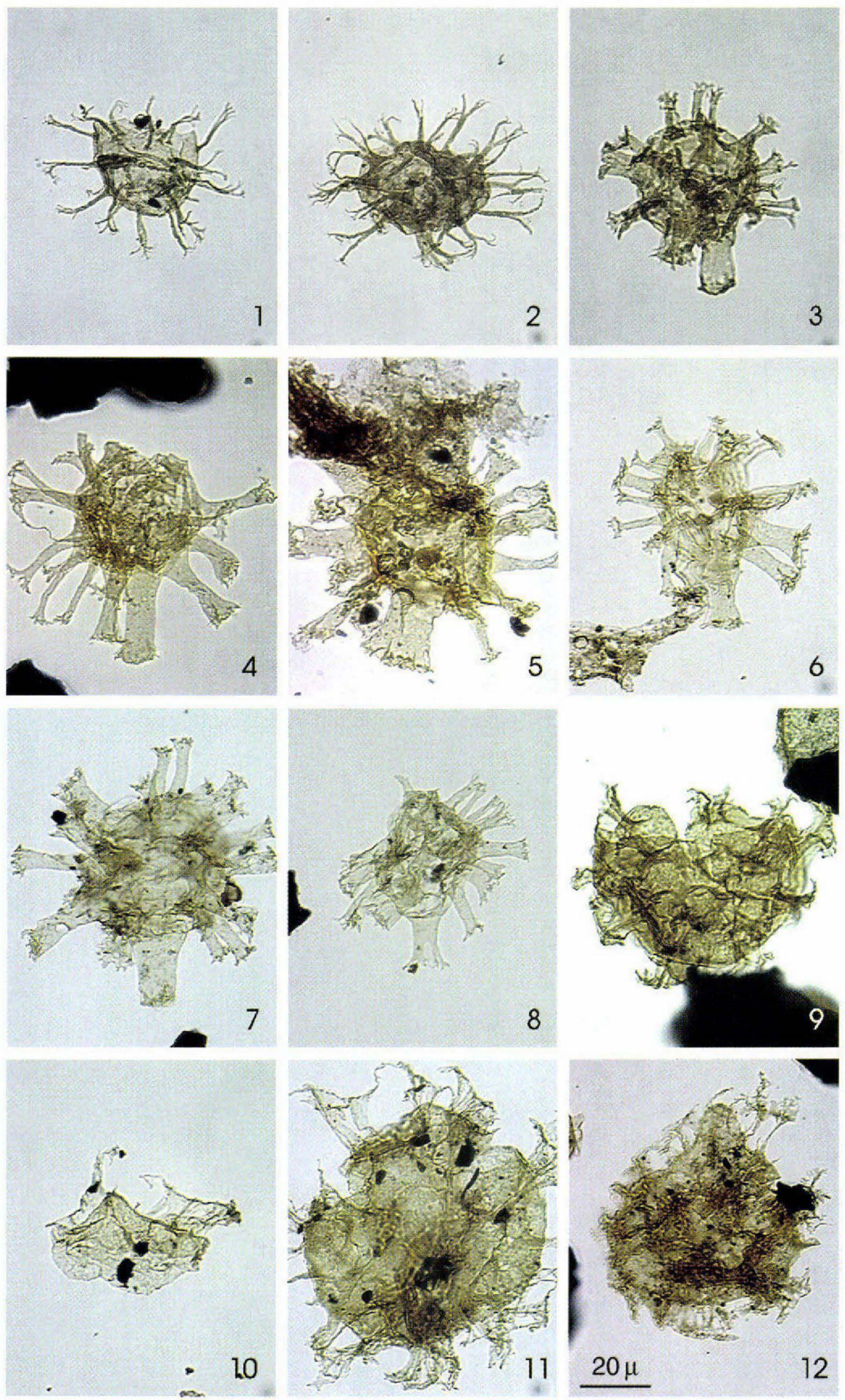

$\therefore 10$

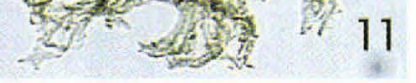

$20 \mu$ 
Plate 8. Svartenhuk

Fig. 1. Exochosphaeridium sp. 2 HNH, GGU 400711-10-4; 48.6-99.9 LVR 1.1435; MI 918; MGUH 23853.

Fig. 2. Exochosphaeridium sp. 1 HNH, GGU 400710-15-7; 30.7-107.7 LVR 1.1530; MI 1002; MGUH 23854.

Fig. 3. Exochosphaeridium sp. 1 HNH, GGU 400712-17-4; 53.1-108.0 LVR 1.1724; MI 1180; MGUH 23855.

Fig. 4. Chlamydophorella? sp. 4 HNH, GGU 400712-14 4; 48.2-105.7; LVR 1.1635; MI 1093; MGUH 23856.

Fig. 5. Spiniferites sp., GGU 402680-4, HNH 920822/5; 53.0-106.0; LVR 1.1196; MI 714; MGUH 23857.

Fig. 6. Chorate sp. 15 HNH, GGU 400711-6-7; 30.5 97.7; LVR 1.1503; MI 980; MGUH 23858.

Fig. 7. Cleistosphaerididum aciculare, GGU 402628-4, HNH 920809/1; 23.2-109.9; LVR 1.1239; MI 756; MGUH 23859.

Fig. 8. Cleistosphaerididum aciculare, GGU 402664-9, 400712; 49.4-112.6; LVR 1.1625; MI 1084; MGUH 23860.

Fig. 9. Cleistosphaerididum aciculare, GGU 400712-24-3; 24.4-111.7; LVR 1.1773; MI 1226; MGUH 23861.

Fig. 10. Veryhachium cruciatum, GGU 400708-20-4; 28.2-107.8; LVR 1.1287; MI 793; MGUH 23862.

Fig. 11. Veryhachium cruciatum, GGU 400711-12-4; 33,0-106.7; LVR 1.1386; MI 876; MGUH 23863.

Fig. 12. Raphidodinium fucatum, GGU 400709-24-3; 47.9-96.3; LVR 1.765; MI 442; MGUH 23864. 

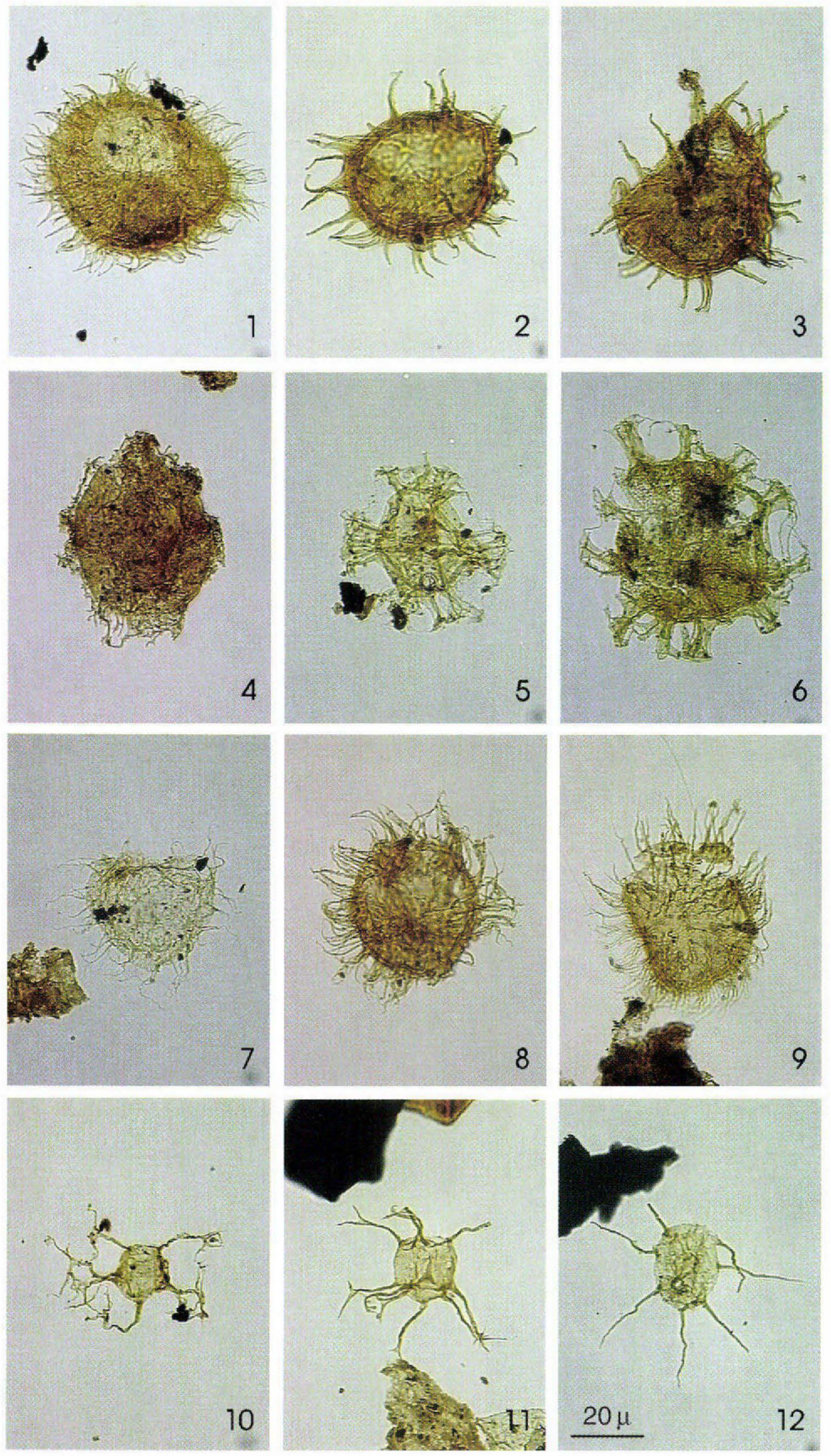
Plate 9. Svartenhuk

Fig. 1. Desmocysta plekta, GGU 402601-4, HNH 92086/1; 34.8-92.5; LVR 1.1166; MI 685; MGUH 23865.

Fig. 2. Desmocysta plekta, GGU 400711-12-5; 30.0-105.7; LVR 1.1411; MI 898; MGUH 23866.

Fig. 3. Desmocysta sp. aff. D. plekta, GGU 400710-9-9; 27.9-101.9; LVR 1.2791; MI 2078; MGUH 23867.

Fig. 4. Dinogymnium sp. cf. D. sibiricum, GGU 251506-8, JGL; 48.8-100.4; LVR 1.705; MI 388; MGUH 23868.

Fig. 5. Dinogymnium sp. cf. D. sibiricum, GGU 251507-4, JGL; 52.3-105.5; LVR 1.713; MI 394; MGUH 23869.

Fig. 6. Dinocyst sp. 7. HNH, GGU 400710-15-4; 44.2-91.7; LRV 1.1525; MI 997; MGUH 23870.

Fig. 7. Fromea fragilis, GGU 400709-26-3; 43.5-102.5; LVR 1.731; MI 410; MGUH 23871.

Fig. 8. Fromea amphora, GGU 400711-12-4; 47.0-96.5; LVR 1.1408; MI 895; MGUH 23872.

Fig. 9. Wallodinium anglicum, GGU 400712-23-3; 27.4-103.0; LVR 1.1745; MI 1201; MGUH 23873.

Fig. 10. Palaeotetradinium silicorum, GGU 402673-4, HNH 920822/3; 34.7-104.7; LVR 1.677; MI 361; MGUH 23874.

Fig. 11. Trigonopyxidia ginella, GGU 400709-24-3; 27.4-110.9; LVR 1.755; MI 432; MGUH 23875.

Fig. 12. Trigonopyxidia ginella, GGU 400709-22-3; 31.7-98.7; LVR 1.782; MI 458; MGUH 23876. 

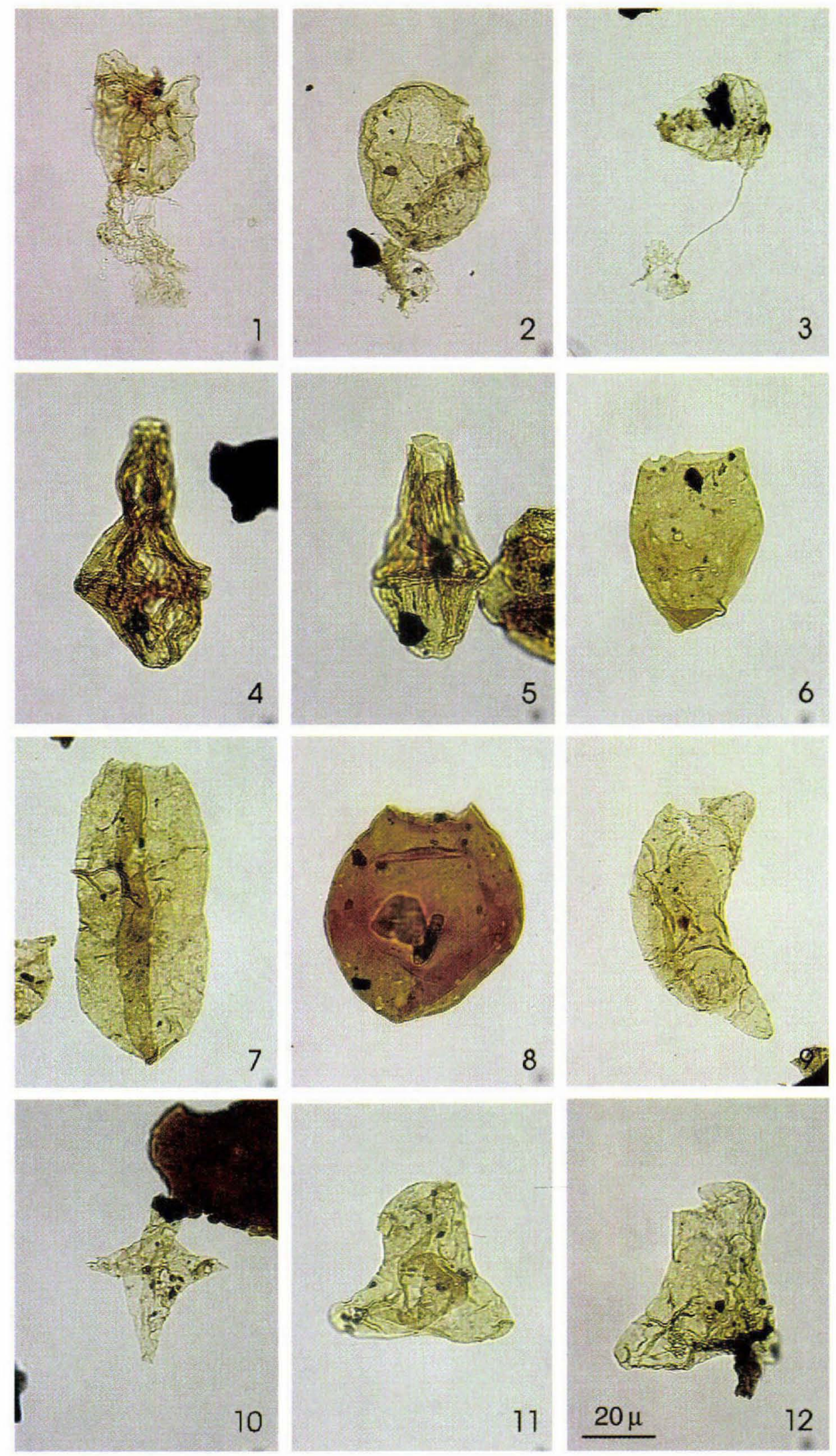
Plate 10. Central Nuussuaq

Fig. 1. Chatangiella bondärenkoi, GGU 366523-3, FGC 900731/2, 47.5-92.9; LVR 1.1889; MI 1333; MGUH 23877.

Fig. 2. Chatangiella bondarenkoi, GGU 360732-6, HNH 910819/1, 33.9-103.3; LVR 1.1970; MI 1400; MGUH 23878.

Fig. 3. Chatangiella bondarenkoi, GGU 360717-5, HNH 910816/1, 22.3-98.8; LVR 1.1944; MI 1379; MGUH 23879.

Fig. 4. Chatangiella bondarenkoi, GGU 366523-6, FGC 900731/2, 19.4-103.1; LVR 1.1884; MI 1330; MGUH 23880.

Fig. 5. Chatangiella bondarenkoi, GGU 400702-12-9, 53.6-106.4; LVR 1.3090; MI 2337; MGUH 23881.

Fig. 6. Chatangiella ditissima, GGU 351822-3, GKP 91-3 Tun., 35.1-106.0; LVR 1.3107; MI 2354; MGUH 23882.

Fig. 7. Chatangiella ditissima, GGU 351822-3, GKP 91-3 Tun., 38.7-103.6; LVR 1.3108; MI 2355; MGUH 23883.

Fig. 8. Laciniadinium arcticum, GGU 369287-4, HNH 910813/1, 26.5-100.5; LVR 1.1907; MI 1348; MGUH 23884.

Fig. 9. Isabelidinium microarmum, GGU 360731-10, HNH 910819/1, 48.7-107.4; LVR 1.1962; MI 1394; MGUH 23885.

Fig. 10. Isabelidinium microarmum, GGU 360732-6, HNH 910819/1, 33.3-114.3; LVR 1.1969; MI 1399; MGUH 23886.

Fig. 11. Chatangiella sp. cf. C. hexacalpis, GGU 400577-4, GKP 92V2-3, 27.6-96.8; LVR 1.1973; MI 1402; MGUH 23887.

Fig. 12. Chatangiella sp. cf. C. hexacalpis, GGU 400577-4, GKP 92V2-3, 27.6-96.8; LVR 1.1974; MI 1402; MGUH 23887. 


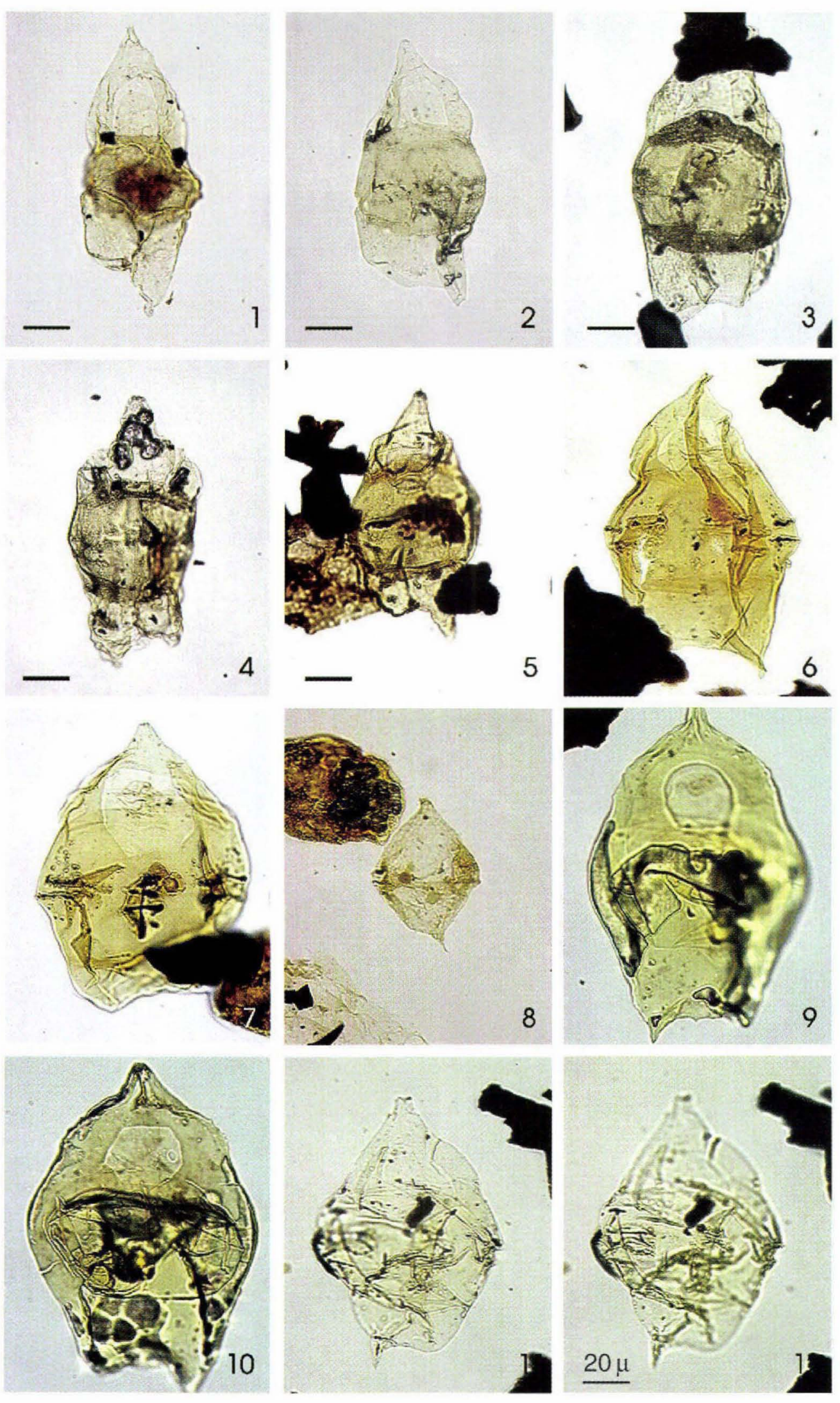


Plate 11. Central Nuussuaq

Fig. 1. Isabelidinium acuminatum, GGU 360717-4, HNH 910816/1, 25.5-95.7; LVR 1.1946; MI 1381; MGUH 23888.

Fig. 2. Isabelidinium acuminatum, GGU 400702-12-9, 38.9-103.0; LVR 1.3081; MI 2329; MGUH 23889.

Fig. 3. Isabelidinium acuminatum, GGU 351824-3 GKP 91-3 Tun., 20.1-102.3; LVR 1.3082; MI 2330; MGUH 23890.

Fig. 4. Isabelidinium acuminatum, GGU 351824-3 GKP 91-3 Tun., 27.8-115.0; LVR 1.3083; MI 2331; MGUH 23891.

Fig. 5. Isabelidinium acuminatum, GGU 400702-12-9, 23.8-108.2; LVR 1.3078; MI 2326; MGUH 23892.

Fig. 6. Isabelidinium acuminatum, GGU 400702-12-9, 33.0-110.4; LVR 1.3080; MI 2328; MGUH 23893.

Fig. 7. Odontochitina striatoperforata, GGU 366523-4 FGC 900731/2, 48.6-108.0; LVR 1.1885; MI 1331; MGUH 23894.

Fig. 8. Odontochitina striatoperforata GGU 369287-6, HNH 910813/1, 55.1-106.0; LVR 1.1927; MI 1365; MGUH 23895.

Fig. 9. Xenascus sp. aff. X. perforatus GGU 400585-6, GKP 92 V1 Qilak., 33.2-104.0; LVR 1.1985; MI 1413; MGUH 23896.

Fig. 10. Palaeocystodinium sp. aff. $P$. golzowenze GGU 400701-4-9, 31.8-93.0; LVR 1.3096; MI 2343; MGUH 23897.

Fig. 11. Batioladinium jaegeri GGU 351828-2, GKP 914 Tun., 43.6-95.5; LVR 1.3109; MI 2356; MGUH 23898.

Fig. 12. Batioladinium jaegeri GGU 351828-3, GKP 914 Tun., 23.8-113.5; LVR 1.3110; MI 2357; MGUH 23899. 

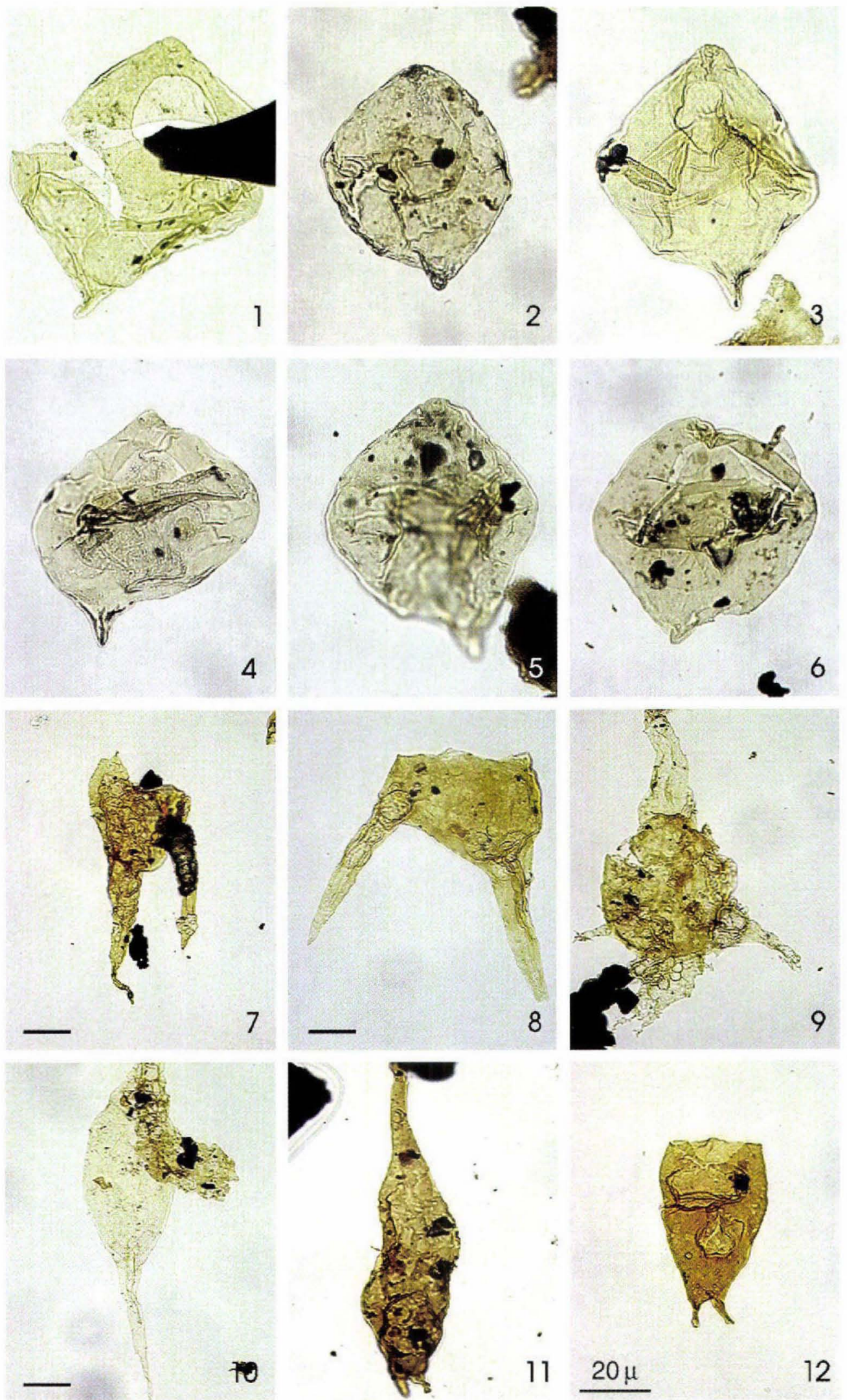

70

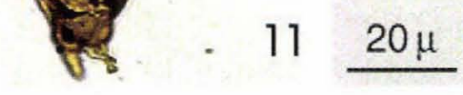

12 
Plate 12. Central Nuussuaq

Fig. 1. Exochosphaeridium sp. aff. E. bifidum, GGU 369284-6, HNH 910813/1, 55.9-100.5; LVR 1.1898; MI 1339; MGUH 23900.

Fig. 2. Exochosphaeridium sp. aff. E. bifidum, GGU 369284-4, HNH 910813/1, 18.9-108.9; LVR 1.1895; MI 1337; MGUH 23901.

Fig. 3. Exochosphaeridium sp. aff. E. striolatum, GGU 369287-6, HNH 910813/1, 45.8-96.8; LVR 1.1930; MI 1368; MGUH 23902.

Fig. 4. Exochosphaeridium sp. aff. E. striolatum, GGU 369287-9, HNH 910813/1, 47.4-96.9; LVR 1.1931; MI 1369; MGUH 23903.

Fig. 5. Hystrichosphaeridium? sp., GGU 351824-3 GKP 91-3 Tun., 49.4-103.7; LVR 1.3098; MI 2345; MGUH 23904.

Fig. 6. Circulodinium distinctum, GGU 360717-9, HNH 910816/1, 55.3-97.8; LVR 1.1943; MI 1378; MGUH 23905.

Fig. 7. Circulodinium sp. cf. C. distinctum, GGU 400702-12-3, 34.7-104.2; LVR 1.3092; MI 2339; MGUH 23906.

Fig. 8. Circulodinium sp. cf. C. distinctum, GGU 400702-12-7, 34.1-111.2; LVR 1.3093; MI 2340; MGUH 23907.

Fig. 9. Trithyrodinium suspectum GGU 400585-8, GKP 92 V1 Qilak., 35.5-100.2; LVR 1.1990; MI 1416; MGUH 23908.

Fig. 10. Tanyosphaeridium variecalamus, GGU 360729-4, HNH 910819/1, 28.0-100.2; LVR 1.1953; MI 1388; MGUH 23909.

Fig. 11. Dinogymnium? sp., GGU 369287-4, HNH 910813/1, 45.1-104.9; LVR 1.1916; MI 1356; MGUH 23910.

Fig. 12. Fromea nicosia, GGU 400702-10-7, 42.9-99.7; LVR 1.3075; MI 2323; MGUH 23911. 

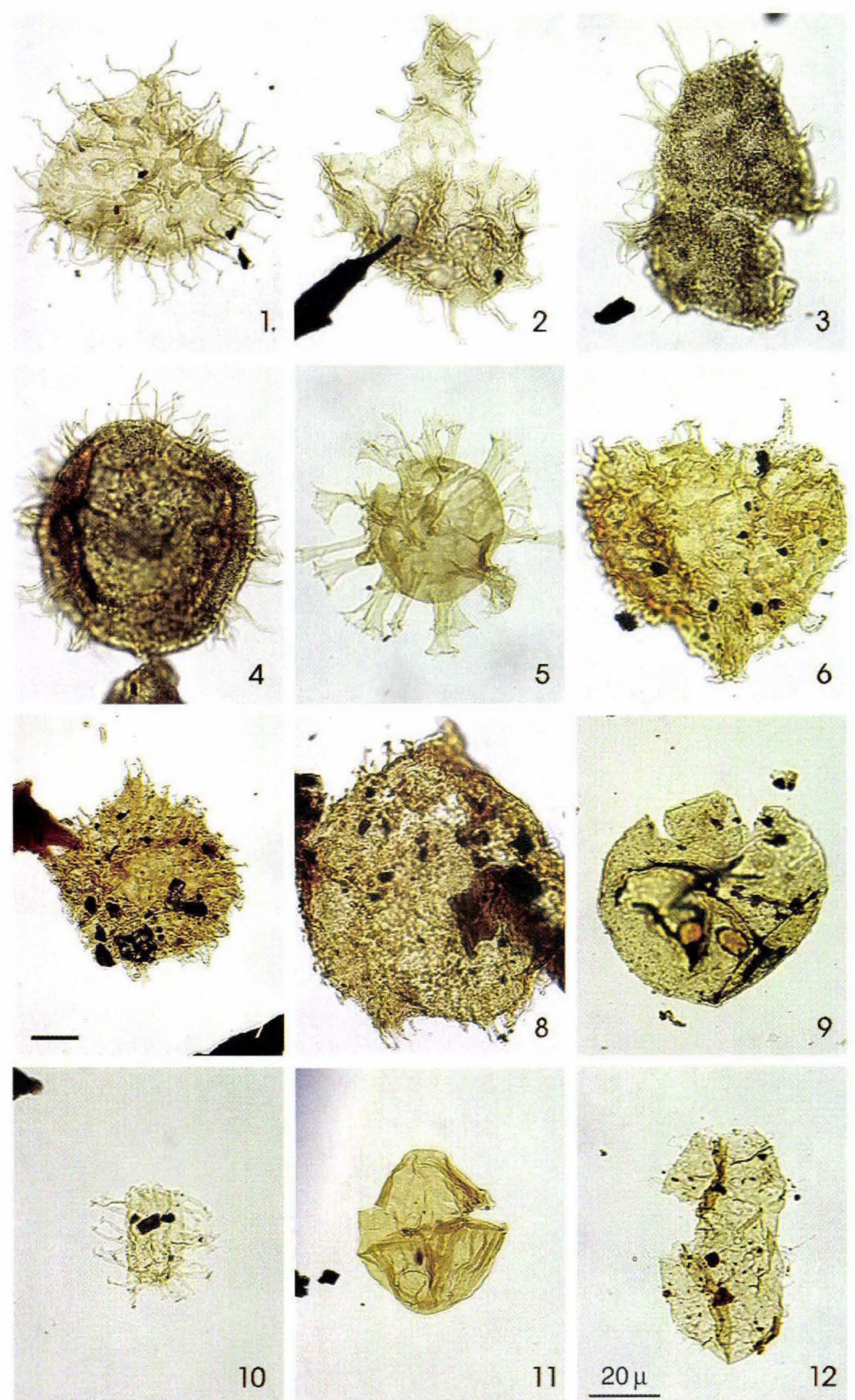

$1120 \mu$ 
Plate 13. Central Nuussuaq

Fig. 1. Cerodinium diebelii, GGU 366589-3, Annertuneq, 26.6-103.0; LVR 1.553; MI 256; MGUH 23912. $\times 40$.

Fig. 2. Cerodinium diebelii, GGU 366906-10, Annertuneq, 48.6-103.9; LVR 1.597; MI 294; MGUH 23913. $\times 40$.

Fig. 3. Cerodinium diebelii, GGU 408888-8, Annertuneq, 31.0-109.6; LVR 1.4050; MI 3008; MGUH 23914. $\times 40$.

Fig. 4. Cerodinium sp. cf. C. diebelii, GGU 408880-4, Annertuneq, 28.0-99.4; LVR 1.4000; MI 2969; MGUH 23915. $\times 40$.

Fig. 5. Cerodinium sp. cf. C. diebelii, GGU 408880-4, Annertuneq, 35.0-109.3; LVR 1.4001; MI 2970; MGUH 23916. $\times 40$.

Fig. 6. Cerodinium sp. cf. C. diebelii, GGU 408881-4, Annertuneq, 44.1-108.4; LVR 1.4007; MI 2975; MGUH 23917. $\times 40$.

Fig. 7. Cerodinium speciosum, GGU 408887-7, Annertuneq, 32.5-106.2; LVR 1.4066; MI 3022; MGUH 23918.

Fig. 8. Cerodinium speciosum, GGU 408887-4, Annertuneq, 23.7-101.6; LVR 1.4068; MI 3024; MGUH 23919.

Fig. 9. Cerodinium speciosum, GGU 366624-4, FGC 900813/7, Ikorfat, 23.5-100.4; LVR 1.4081; MI 3035; MGUH 23920.

Fig. 10. Cerodinium speciosum, GGU 408887-4, Annertuneq, 46.0-96.7; LVR 1.4067; MI 3023; MGUH 23921.

Fig. 11. Phelodinium sp. cf. P. kozlowskii, GGU 366593-4, Annertuneq, 53.7-102.8; LVR 1.663; MI 347; MGUH 23922.

Fig. 12. Phelodinium kozlowskii, GGU 366593-3, Annertuneq, 46.1-102.3; LVR 1.657; MI 342; MGUH 23923. 

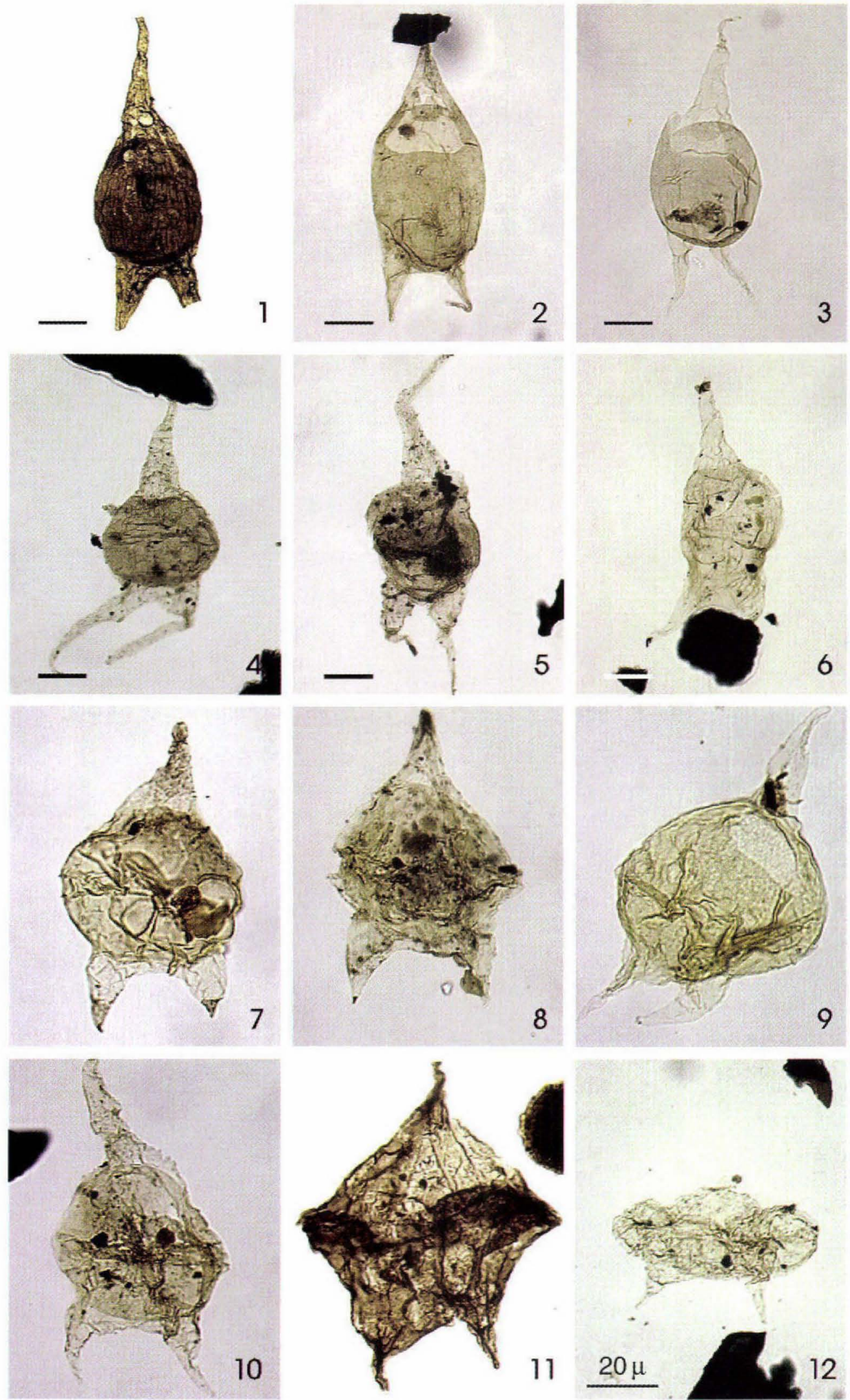
Plate 14. Central Nuussuaq

Fig. 1. Deflandrea galeata, GGU 366591-5, Annertuneq, 56.1-112.8; LVR 1.633; MI 322; MGUH 23924.

Fig. 2. Deflandrea galeata, GGU 408885-2, Annertuneq, 22.3-104.7; LVR 1.4012; MI 2980; MGUH 23925.

Fig. 3. Deflandrea galeata, GGU 408893-4, Annertuneq, 24.4-112.4; LVR 1.4075; MI 3030; MGUH 23926.

Fig. 4. Alterbidinium? ulloriaq sp. nov., holotype, GGU 408887-4, Annertuneq, 41.0-93.0; LVR 1.4061; MI 3018; MGUH 23927.

Fig. 5. Alterbidinium? ulloriaq sp. nov., GGU 408887-3, Annertuneq, 50.0-99.6; LVR 1.4060; MI 3017; MGUH 23928.

Fig. 6. Alterbidinium? ulloriaq sp. nov., GGU 408887-7, Annertuneq, 24.5-95.0; LVR 1.4062; MI 3019; MGUH 23929.

Fig. 7. Alterbidinium? ulloriaq sp. nov., GGU 408887-15, Annertuneq, 37.8-93.9; LVR 1.5719; MI 4354; MGUH 23930.

Fig. 8. Alterbidinium? ulloriaq sp. nov., GGU 408887-14, Annertuneq, 46.7-106.8; LVR 1.5718; MI 4353; MGUH 23931.

Fig. 9. Alterbidinium? ulloriaq sp. nov., GGU 408887-8, Annertuneq, 56.3-107.5; LVR 1.5708; MI 4346; MGUH 23932.

Fig. 10. Alterbidinium? ulloriaq sp. nov., GGU 408887-17, Annertuneq, 51.2-110.3; LVR 1.5722; MI 4355; MGUH 23933.

Fig. 11. Alterbidinium? ulloriaq sp. nov., GGU 408887-17, Annertuneq, 51.2-110.3; LVR 1.5721; MI 4355; MGUH 23933.

Fig. 12. Alterbidinium? ulloriaq sp. nov., GGU 408887-14, Annertuneq, 47.7-94.4; LVR 1.5717; MI 4352; MGUH 23934. 

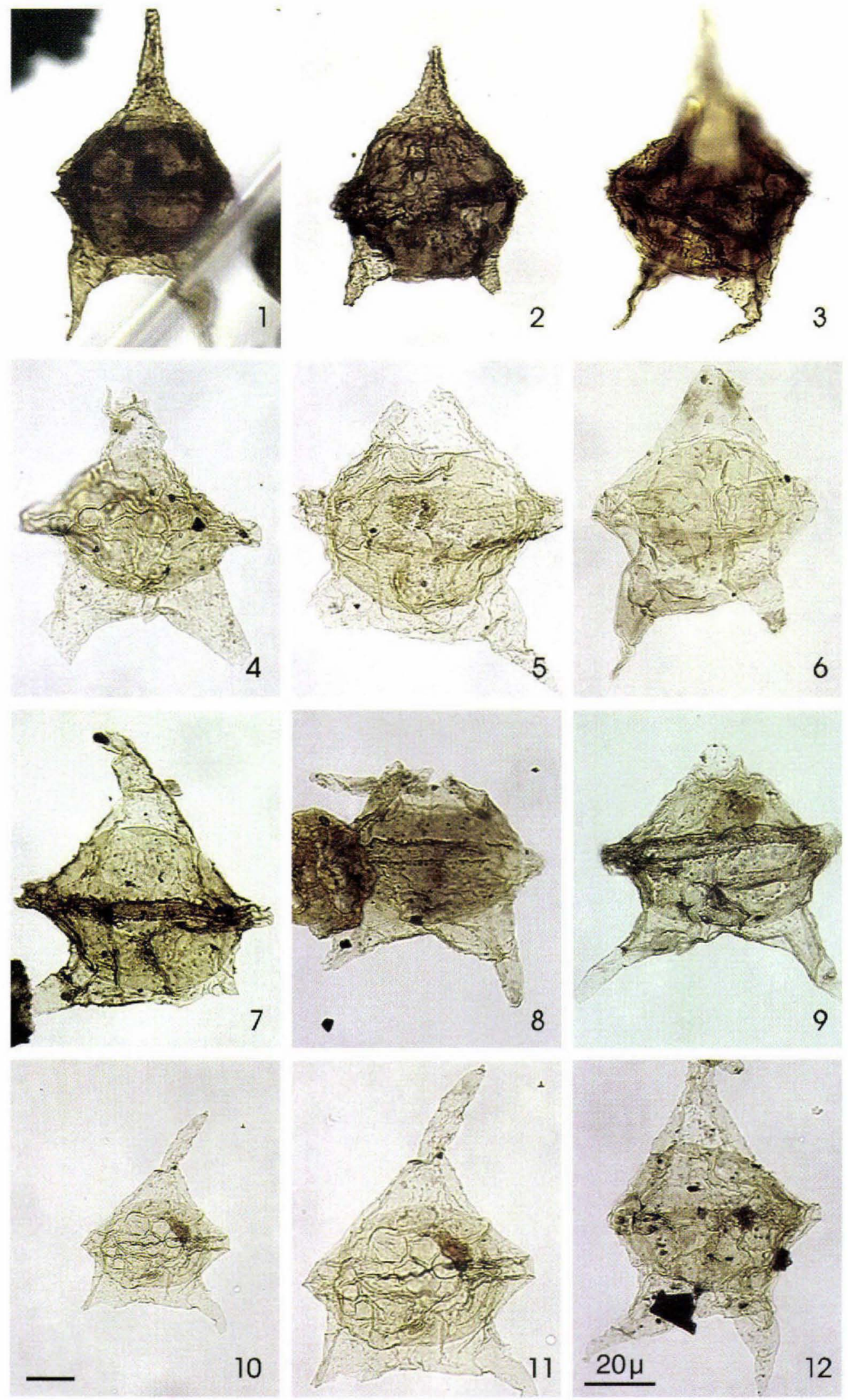
Plate 15. Central Nuussuaq

Fig. 1. Fromea fragilis, GGU 366906-4, Annertuneq, 38.5-98.4; LVR 1.593; MI 290; MGUH 23935.

Fig. 2. Palaeocystodinium golzowense GGU 366906-8, Annertuneq, 41.9-108.1; LVR 1.622; MI 312; MGUH 23936.

Fig. 3. Palaeocystodinium golzowense GGU 366593-4, Annertuneq, 18.3-92.3; LVR 1.662; MI 346; MGUH 23937. 40x

Fig. 4. 'Isabelidinium sp. aff. I. bujakii', GGU 408879-4, Annertuneq, 39.4-93.9; LVR 1.3998; MI 2967; MGUH 23938.

Fig. 5. 'Isabelidinium sp. aff. I. bujakii', GGU 408880-4, Annertuneq, 40.6-105.8; LVR 1.4002; MI 2971; MGUH 23939.

Fig. 6. Isabelidinium cooksoniae, GGU 366583-4, Annertuneq, 42.8-102.7; LVR 1.447; MI 166; MGUH 23940.

Fig. 7. Isabelidinium cooksoniae, GGU 366585-4, Annertuneq, 56.4-98.4; LVR 1.479; MI 192; MGUH 23941.

Fig. 8. Isabelidinium cooksoniae, GGU 366584-4, Annertuneq, 43.4-104.0; LVR 1.452; MI 169; MGUH 23942.

Fig. 9. Isabelidinium cooksoniae, GGU 366584-4, Annertuneq, 28.5-95.3; LVR 1.456; MI 172; MGUH 23943.

Fig. 10. Isabelidinium cooksoniae, GGU 366579-4, Annertuneq, 26.5-108.7; LVR 1.87; MI 17; MGUH 23944.

Fig. 11. Isabelidinium? viborgense, GGU 366624-4, FGC 900813/7 Ikorfat, 24.0-104.2; LVR 1.4078; MI 3032; MGUH 23945.

Fig. 12. ?Isabelidinium? viborgense, GGU 366624-4, FGC 900813/7 Ikorfat, 47.0-105.5; LVR 1.4080; MI 3034; MGUH 23946. 

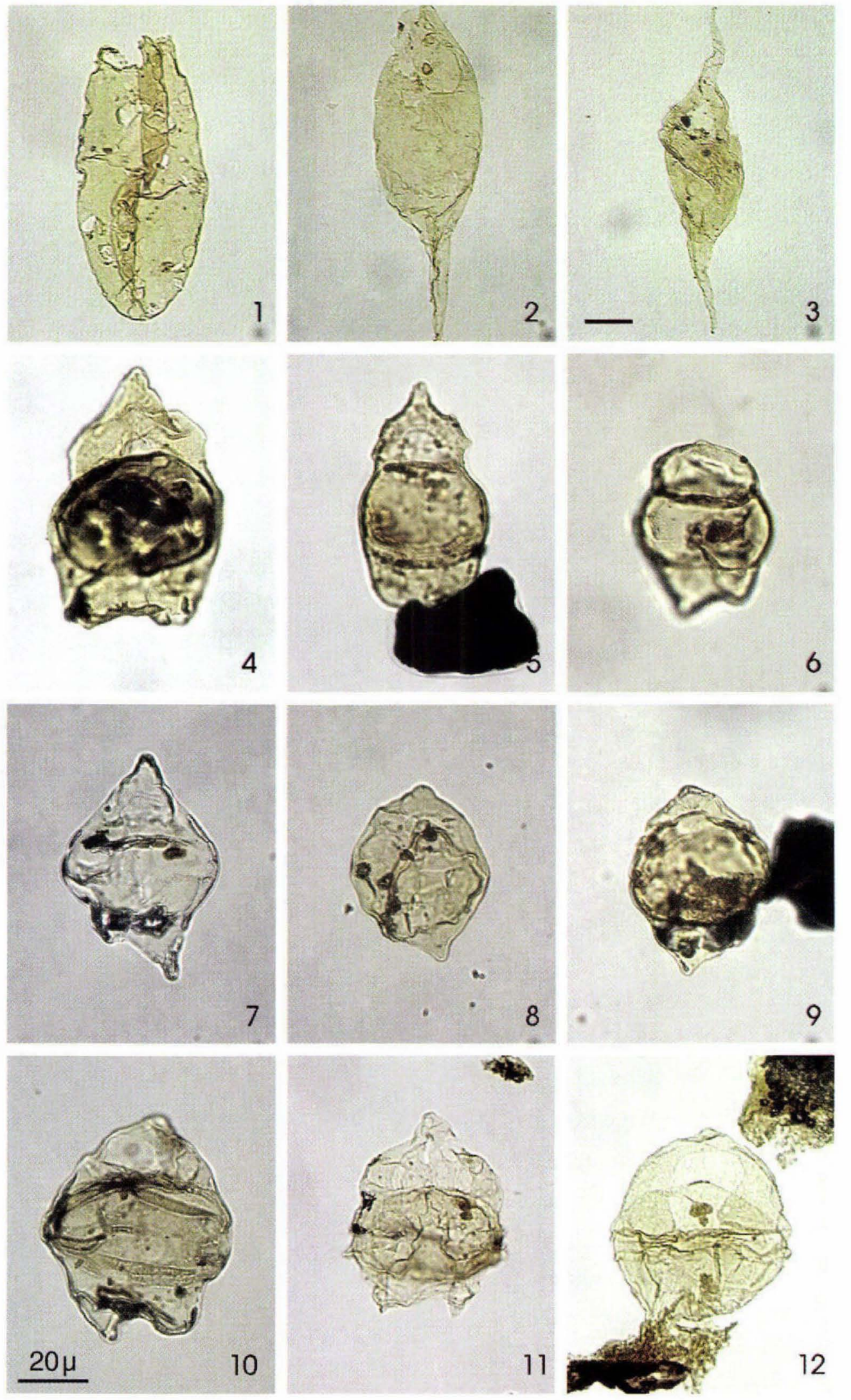
Plate 16. Central Nuussuaq

Fig. 1. 'Hystrichosphaeridium proprium proprium', GGU 366589-3, Annertuneq, 50.6-93.9; LVR 1.542; MI 245; MGUH 23947.

Fig. 2. 'Hystrichosphaeridium proprium proprium', GGU 366589-7, Annertuneq, 48.0-95.0; LVR 1.545; MI 248; MGUH 23948.

Fig. 3. 'Hystrichosphaeridium proprium proprium', GGU 366590-8, Annertuneq, 23.5-109.2; LVR 1.581; MI 281; MGUH 23949.

Fig. 4. 'Hystrichosphaeridium proprium brevispinum', GGU 408885-4, Annertuneq, 49.4-111.1; LVR 1.4016; MI 2983; MGUH 23950.

Fig. 5. 'Hystrichosphaeridium proprium brevispinum', GGU 408886-4, Annertuneq, 41.1-106.0; LVR 1.4020; MI 2987; MGUH 23951.

Fig. 6. 'Hystrichosphaeridium proprium brevispinum', GGU 408886-4, Annertuneq, 41.1-106.0; LVR 1.4022; MI 2987; MGUH 23951.

Fig. 7. 'Hystrichosphaeridium proprium brevispinum', GGU 408886-8, Annertuneq, 35.4-103.5; LVR 1.4023; MI 2988; MGUH 23952.

Fig. 8. 'Hystrichosphaeridium proprium brevispinum', GGU 408886-8, Annertuneq, 35.4-103.5; LVR 1.4024; MI 2988; MGUH 23952.

Fig. 9. 'Hystrichosphaeridium proprium brevispinum', GGU 408886-8, Annertuneq, 35.4-103.5; LVR 1.4025; MI 2988; MGUH 23952.

Fig. 10. Hystrichosphaeridium sp. cf. H. stellatum, GGU 366586-4, Annertuneq, 45.9-102.3; LVR 1.500; MI 208; MGUH 23953.

Fig. 11. Fibrocysta sp. cf. F. vectensis sensu Ioannides (1986), GGU 366588-7, Annertuneq, 28.5-110.7; LVR 1.530; MI 233; MGUH 23954.

Fig. 12. Glaphyrocysta sp., GGU 408891-4, Annertuneq, 27.0-105.5; LVR 1.4069; MI 3025; MGUH 23955. 

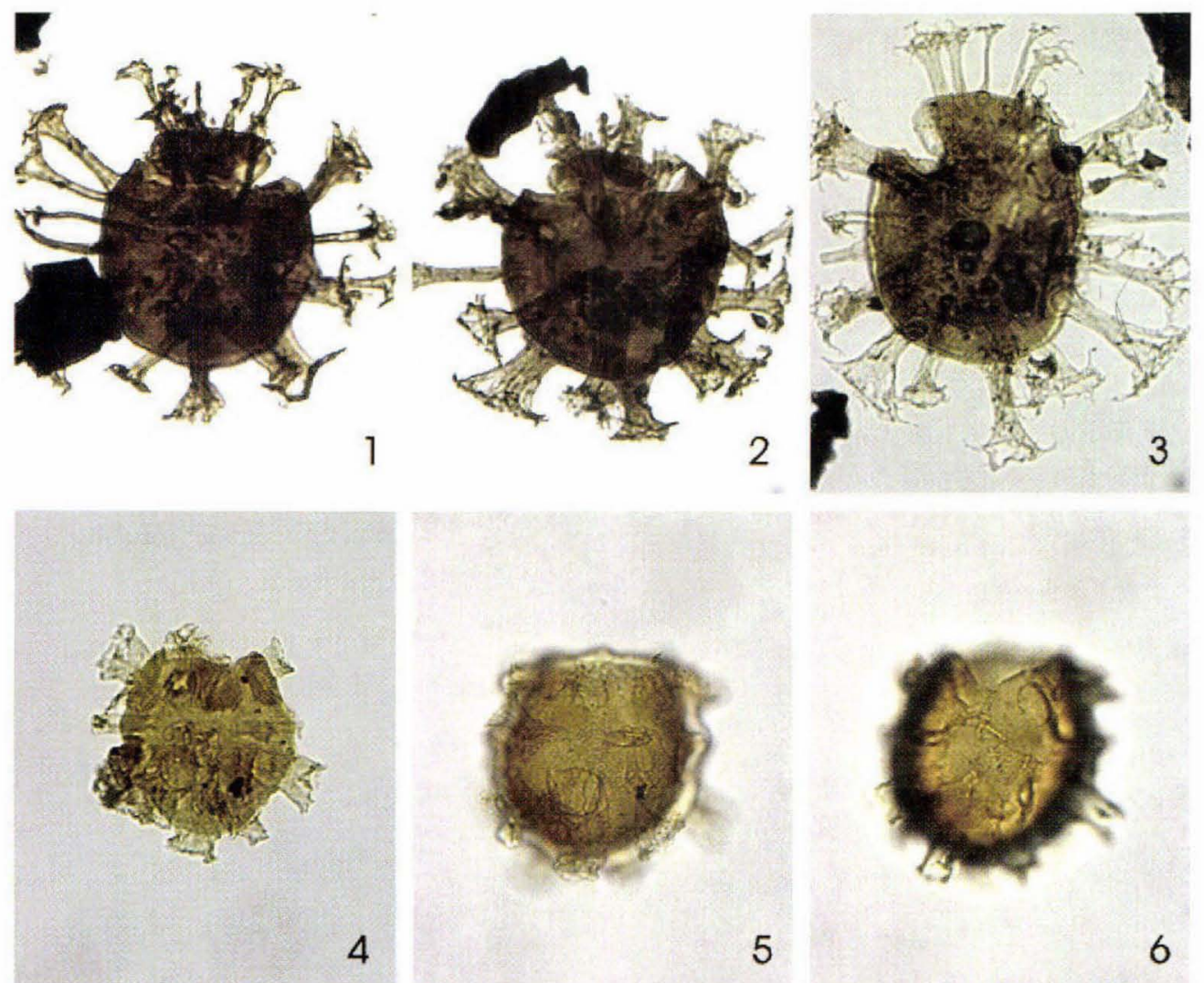

4

5
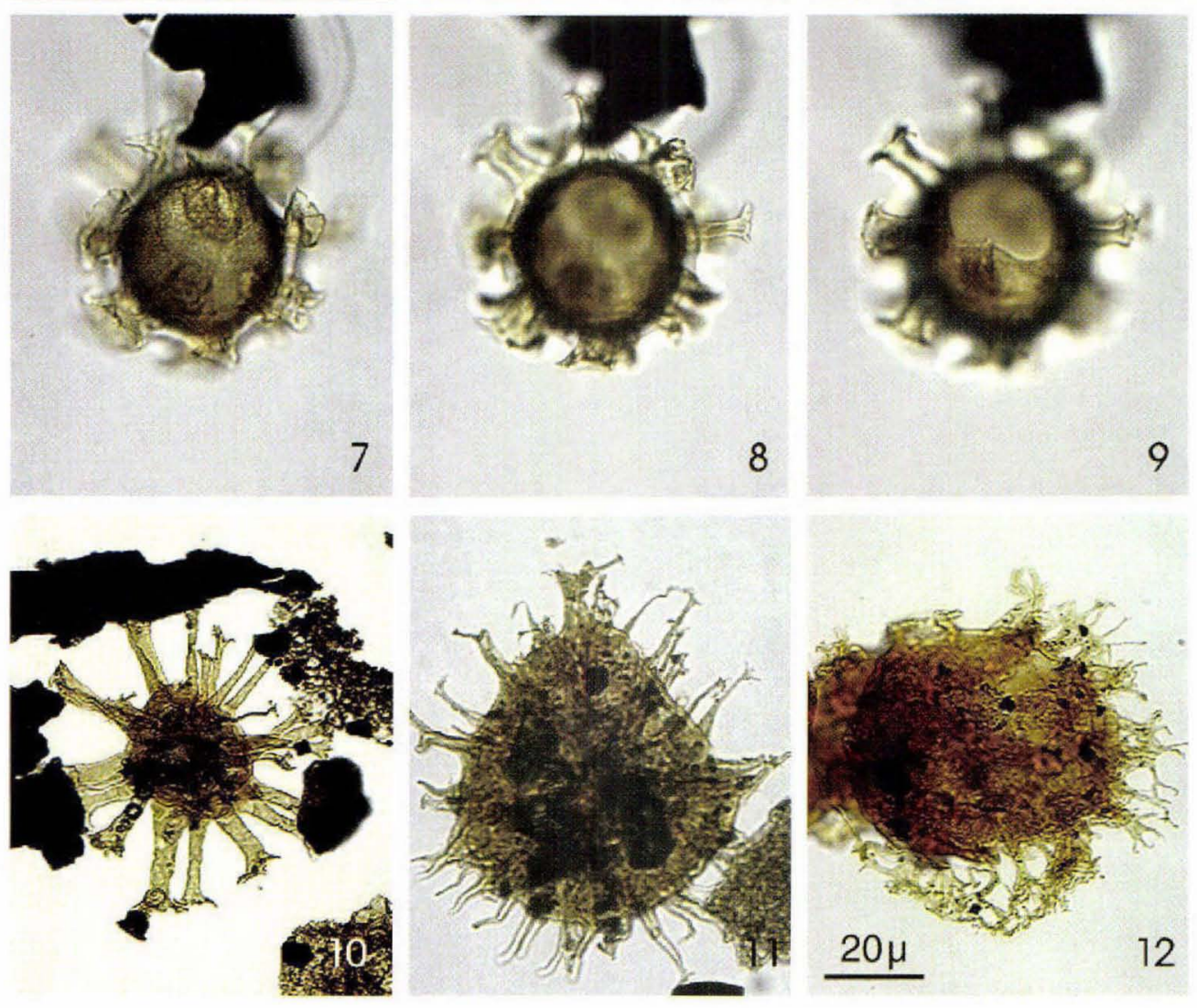
Plate 17. Central Nuussuaq

Fig. 1. Impagidinium sp. cf. I. dispertitum, GGU 408886-8, Annertuneq, 33.0-107.0; LVR 1.4041; MI 3003; MGUH 23956.

Fig. 2. Impagidinium sp. cf. I. dispertitum, GGU 408886-8, Annertuneq, 33.0-107.0; LVR 1.4042; MI 3003; MGUH 23956.

Fig. 3. Impagidinium sp. cf. I. dispertitum, GGU 408886-8, Annertuneq, 33.0-107.0; LVR 1.4043; MI 3003; MGUH 23956.

Fig. 4. Impagidinium sp. cf. I. dispertitum, GGU 408886-8, Annertuneq, 41.4-99.6; LVR 1.4044; MI 3004; MGUH 23957.

Fig. 5. Impagidinium sp. cf. I. dispertitum, GGU 408886-8, Annertuneq, 41.4-99.6; LVR 1.4045; MI 3004; MGUH 23957.

Fig. 6. Impagidinium sp. cf. I. dispertitum, GGU 408886-8, Annertuneq, 41.4-99.6; LVR 1.4046; MI 3004; MGUH 23957.

Fig. 7. Spinidinium? sp. cf. S. clavus, GGU 366906-4, Annertuneq, 30.7-95.1; LVR 1.589; MI 287; MGUH 23958.

Fig. 8. Laciniadinium arcticum, GGU 366582-4, Annertuneq, 39.8-107.0; LVR 1.425; MI 148; MGUH 23959.

Fig. 9. Laciniadinium arcticum, GGU 366588-7, Annertuneq, 43.7-94.4; LVR 1.521; MI 225; MGUH 23960.

Fig. 10. Chatangiella sp. aff. C. granulifera, GGU 366589-4, Annertuneq, 49.6-106.2; LVR 1.538; MI 241; MGUH 23961.

Fig. 11. Raphidodinium fucatum, GGU 366582-4, Annertuneq, 56.1-96.1; LVR 1.422; MI 145; MGUH 23962.

Fig. 12. Raphidodinium fucatum, GGU 366583-4, Annertuneq, 34.6-100.7; LVR 1.451; MI 168; MGUH 23963. 

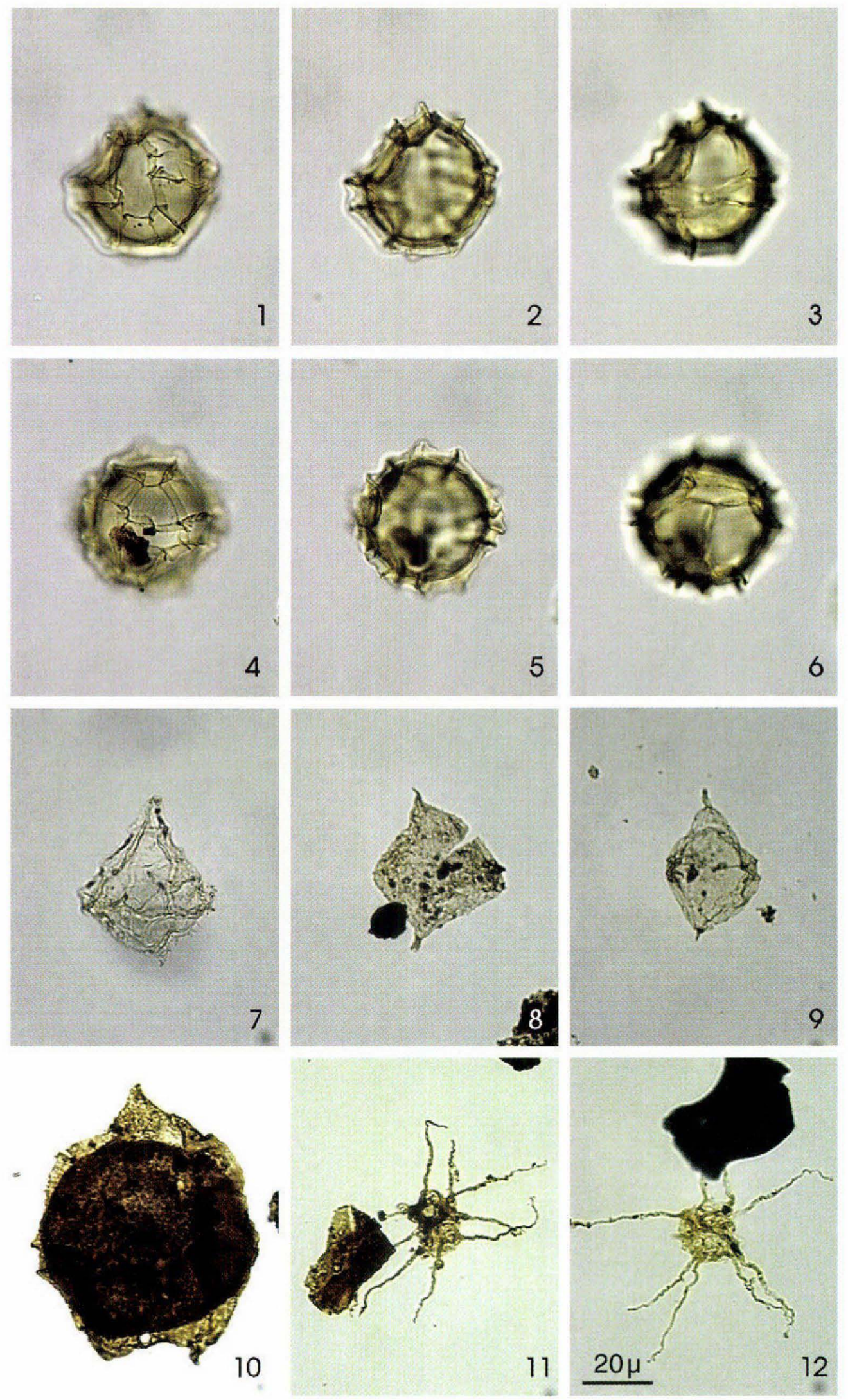
Plate 18. Central Nuussuaq

Fig. 1. Aquilapollenites stelckii, GGU 366582-7, Annertuneq, 25.4-102.2; LVR 1.431; MI 153; MGUH 23964.

Fig. 2. Aquilapollenites stelckii, GGU 366583-4, Annertuneq, 23.0-96.1; LVR 1.432; MI 154; MGUH 23965.

Fig. 3. Aquilapollenites stelckii, GGU 366584-7, Annertuneq, 36.2-109.8; LVR 1.460; MI 176; MGUH 23966.

Fig. 4. Aquilapollenites stelckii, GGU 366906-4, Annertuneq, 47.3-102.0; LVR 1.599; MI 296; MGUH 23967.

Fig. 5a. Aquilapollenites clarireticulatus, GGU 366906-4, Annertuneq, 46.9-112.3; LVR 1.600; MI 297; MGUH 23968.

Fig. 5b. Aquilapollenites clarireticulatus, GGU 366906-4, Annertuneq, 46.9-112.3; LVR 1.601; MI 297; MGUH 23968.

Fig. 6a. Aquilapollenites drumhellerensis, GGU 366906-4, Annertuneq, 49.1-108.3; LVR 1.603; MI 299; MGUH 23969.

Fig. 6b. Aquilapollenites drumhellerensis, GGU 366906-4, Annertuneq, 39.3-101.3; LVR 1.604; MI 300; MGUH 23969.

Fig. 7. Aquilapollenites sp., GGU 366592-4, Annertuneq, 45.8-98.0; LVR 1.640; MI 328; MGUH 23970.

Fig. 8. Aquilapollenites sp., GGU 366586-3, Annertuneq, 55.5-99.4; LVR 1.493; MI 204; MGUH 23971.

Fig. 9. Aquilapollenites clarireticulatus, GGU 366906-4, Annertuneq, 38.7-95.7; LVR 1.602; MI 298; MGUH 23972.

Fig. 10. Aquilapollenites sp., GGU 408886-4, Annertuneq, 25.1-92.0; LVR 1.4026; MI 2989; MGUH 23973.

Fig. 11. Pseudointegricorpus protrusum, GGU 366589-7, Annertuneq, 44.6-111.5; LVR 1.566; MI 267; MGUH 23974.

Fig. 12. Pseudointegricorpus protrusum, GGU 366906-4, Annertuneq, 42.2-100.0; LVR 1.605; MI 301; MGUH 23975. 

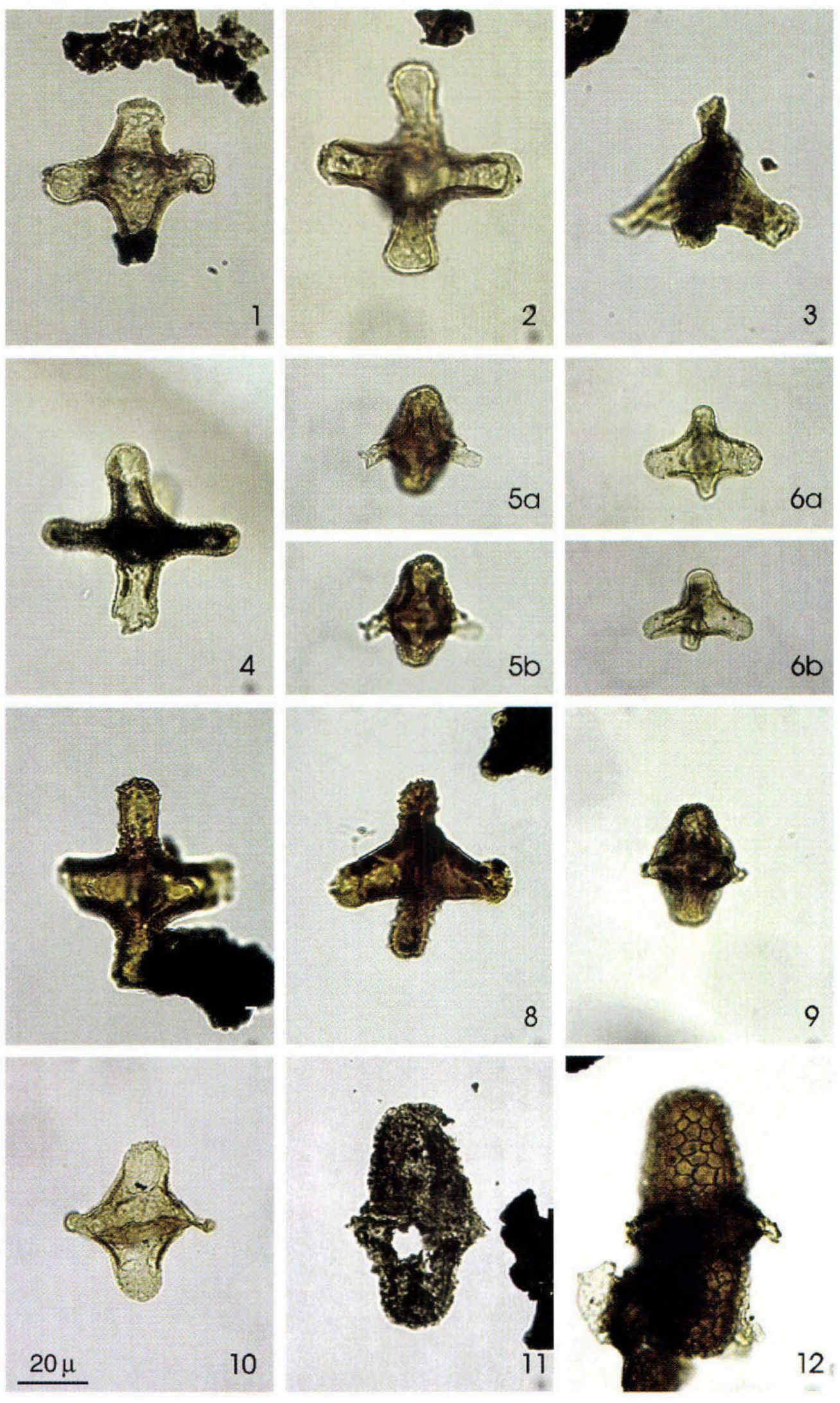
Plate 19. Central Nuussuaq

Fig. 1. Wodehouseia spinata, GGU 366906-4, Annertuneq, 38.7-96.2; LVR 1.596; MI 293; MGUH 23976.

Fig. 2. Wodehouseia spinata, GGU 408892-3, Annertuneq, 22.2-110.8; LVR 1.4071; MI 3027; MGUH 23977.

Fig. 3. Wodehouseia spinata, GGU 408893-7, Annertuneq, 41.3-101.7; LVR 1.4074; MI 3029; MGUH 23978.

Fig. 4. Wodehouseia stanleyi, GGU 366592-4, Annertuneq, 50.9-95.4; LVR 1.641; MI 329; MGUH 23979.

Fig. 5. Wodehouseia stanleyi, GGU 408886-4, Annertuneq, 25.6-109.1; LVR 1.4027; MI 2990; MGUH 23980.

Fig. 6. Wodehouseia stanleyi, GGU 408886-8, Annertuneq, 48.3-108.6; LVR 1.4032; MI 2994; MGUH 23981.

Fig. 7. Wodehouseia quadrispina, GGU 408886-4, Annertuneq, 35.4-103.7; LVR 1.4028; MI 2991; MGUH 23982.

Fig. 8. Wodehouseia quadrispina, GGU 408886-8, Annertuneq, 46.3-107.9; LVR 1.4030; MI 2993; MGUH 23983.

Fig. 9. Wodehouseia sp. cf. W. fimbriata, GGU 408892-4, Annertuneq, 41.7-101.4; LVR 1.4072; MI 3028; MGUH 23984.

Fig. 10. Wodehouseia sp. cf. W. fimbriata, GGU 408892-4, Annertuneq, 41.7-101.4; LVR 1.4073; MI 3028; MGUH 23984.

Fig. 11. ?Scollardia sp. cf. S. trapaformis, GGU 408886-8, Annertuneq, 29.2-98.7; LVR 1.4048; MI 3006; MGUH 23985.

Fig. 12. ?Scollardia sp. cf. S. trapaformis, GGU 366592-4, Annertuneq, 30.2-110.0; LVR 1.644; MI 331; MGUH 23986. 

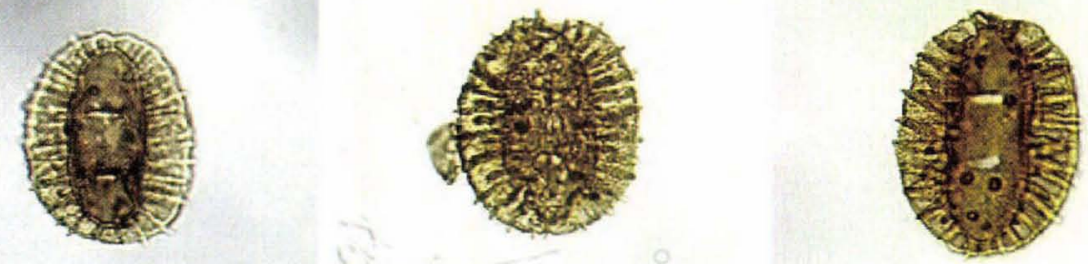

1

2

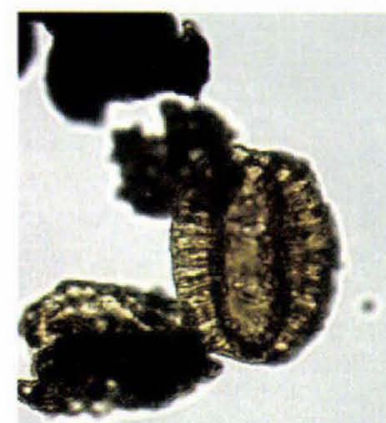

4
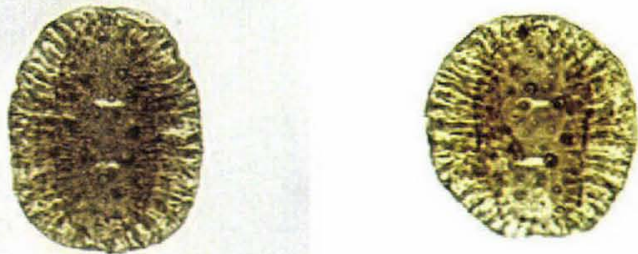

5
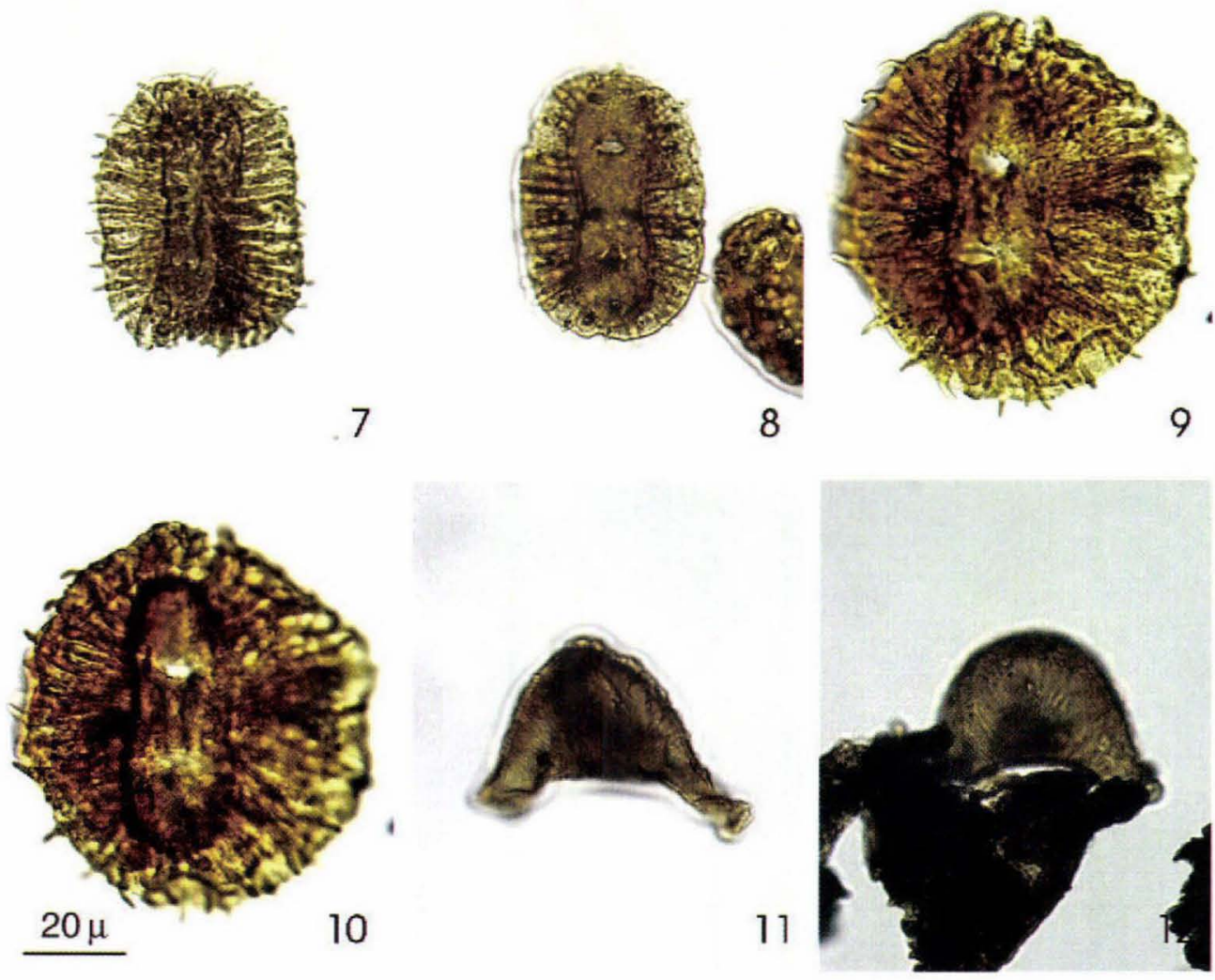


\section{Index of figured species}

Alterbidinium? ulloriaq sp. nov

Plate

Arvalidinium scheii

Batioladinium jaegeri

Cerodinium diebelii

Cerodinium sp. aff. C. diebelii

Cerodinium speciosum

Chatangiella bondarenkoi

Chatangiella ditissima

Chatangiella sp. cf. C. ditissima.

Chatangiella granulifera

Chatangiella sp. aff. C. granulifera

Chatangiella sp. cf. C. hexacalpis

Chatangiella sp. cf. C. madura

Chatangiella sp. aff. C. spectabilis

Chatangiella mcintyrei sp. nov.

Chatangiella verrucosa

Chlamydophorella? sp. aff. C. grossa

Chlamydophorella? sp. $4 \mathrm{HNH}$

Cleistosphaeridium aciculare

Circulodinium distinctum

Circulodinium sp. cf. C. distinctum

Cribroperidinium sp. aff. C. intricatum

Deflandrea galeata

Desmocysta plekta

Desmocysta sp. aff. D. plekta

Dinocyst sp. B HNH

Dinocyst sp. $7 \mathrm{HNH}$

Dinogymnium sp. cf. $D$. sibiricum .

Dinogymnium? sp.

Dinopterygium sp. aff. $D$. cladoides

Endoscrinium campanula.

Exochosphaeridium bifidum

Exochosphaeridium striolatum

Exochosphaeridium sp. $1 \mathrm{HNH}$

Exochosphaeridium sp. $2 \mathrm{HNH}$

Fibrocysta sp. cf. F vectensis

Florentinia deanei

Florentinia mantellii

Fromea amphora

Fromea fragilis

Fromea nicosia

Glaphyrocysta sp.

Heterosphaeridium difficile

Hystrichodinium pulchrum

'Hystrichosphaeridium proprium brevispinum'

'Hystrichosphaeridium proprium proprium'

Hystrichosphaeridium sp. cf. H. stellatum

Hystrichosphaeridium? sp.

Impagidinium sp. cf. I. dispertitum .

Isabelidinium acuminatum

Isabelidinium $\mathrm{sp}$. aff. I. acuminatum

'Isabelidinium sp. aff. I. bujakii'

Isabelidinium cooksoniae

Isabelidinium microarmum

Isabelidinium svartenhukense $\mathrm{sp}$. nov

Isabelidinium? viborgense

\begin{tabular}{|c|c|c|c|}
\hline .. Plate & 14 & Figs & $4-12$ \\
\hline ........... Plate & 1 , & Figs & 1-3 \\
\hline ............ Plate & 11 , & Figs & $11-12$ \\
\hline ........... Plate & 13 & Figs & 1-3 \\
\hline ..........Plate & 13 , & Figs & $4-6$ \\
\hline ... Plate & 13 , & Figs & $7-10$ \\
\hline ... Plate & 10 & Figs & $1-5$ \\
\hline ... Plate & 10 & Figs & $6-7$ \\
\hline .... Plate & 1 , & Figs & $11-12$ \\
\hline ........... Plate & 1, & Figs & $4-7$ \\
\hline .... Plate & 17 & Fig. & 10 \\
\hline ............ Plate & 10 & Figs & $11-12$ \\
\hline ..... Plate & 2 & Figs & $1-3$ \\
\hline .... Plate & 2 & Figs & $10-12$ \\
\hline ....Plate & 2 , & Figs & 4-9 \\
\hline .... Plate & 1, & Figs & $8-10$ \\
\hline ....Plate & 5 , & Fig. & 4 \\
\hline .....................Plate & 8 & Fig. & 4 \\
\hline ...... Plate & 8 & Figs & $7-9$ \\
\hline ...... Plate & 12 & Fig. & 6 \\
\hline .... Plate & 12 & Figs & $7-8$ \\
\hline .....Plate & 4 & Fig. & 7 \\
\hline ..... Plate & 14 & Figs & $1-3$ \\
\hline ... Plate & 9 & Figs & $1-2$ \\
\hline Plate & 9 & Fig. & 3 \\
\hline .............Plate & 14 & Fig. & 12 \\
\hline ..................ate & 9 & Fig. & 6 \\
\hline ............... Plate & 9 & Figs & $4-5$ \\
\hline ....Plate & 12 & Fig. & 11 \\
\hline Plate & 4 & Figs & $8-9$ \\
\hline . & 4 & Fig. & 11 \\
\hline Plate & 12 , & Figs & $1-2$ \\
\hline . Plate & 12 & Figs & $3-4$ \\
\hline . & 8 & Figs & $2-3$ \\
\hline 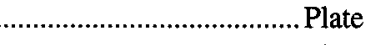 & 8, & Fig. & 1 \\
\hline . Plate & 16 , & Fig. & 11 \\
\hline 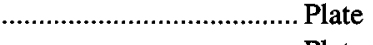 & 7 & Figs & $4-5,8$ \\
\hline Plate & 7, & Figs & $3,6-7$ \\
\hline Plate & 9 & Fig. & 8 \\
\hline Plate 9, Fig. 7; Plate & 15 , & Fig. & 1 \\
\hline Plate & 12 & Fig. & 12 \\
\hline . Plate & 16 , & Fig. & 12 \\
\hline Plate & 7 & Figs & $9-12$ \\
\hline 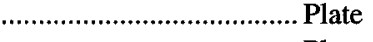 & 6 & Fig. & 12 \\
\hline 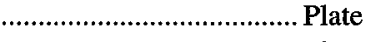 & 16 , & Figs & $4-9$ \\
\hline Plate & 16 , & Figs & $1-3$ \\
\hline . Plate & 16 & Fig. & 10 \\
\hline . Plate & 12 , & Fig. & 5 \\
\hline 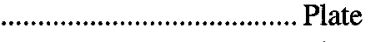 & 17, & Figs & $1-6$ \\
\hline . & 11, & Figs & $1-6$ \\
\hline Plate & 3 & Figs & $4-6$ \\
\hline 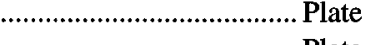 & 15 , & Figs & $4-5$ \\
\hline Plate & 15 , & Figs & $6-10$ \\
\hline ................. Plate & 10 & Figs & $10-11$ \\
\hline . & 3 & Figs & $7-12$ \\
\hline .............................. Plate & 15 & Figs & $11-12$ \\
\hline
\end{tabular}

14, Figs 4-12

$1-3$

1-3

$4-6$

1-5

6-7

$4-7$

10

$1-3$

$-12$

$-10$

4 
IIsabelidinium sp. $7 \mathrm{HNH}$

Plate 3, Figs

1-3

Laciniadinium arcticum.

Plate 4, Fig. 1; Plate 10, Fig.

8; Plate

.. Plate

Microdinium reticulatum

Plate 5, Figs 5-8; Plate

Odonthochitina striatoperforata.

Plate

Oligosphaeridium complex

Plate

Oligosphaeridium sp. aff. $O$. pulcherrimum.

Plate

Palaeocystodinium golzowense .

Plate

Palaeocystodinium sp. aff. $P$. golzowenze

Plate

Palaeohystrichodinium infusorioides

Plate

Phelodinium kozlowskii

Plate

Phelodinium sp. cf. P. kozlowskii

Plate

Raphidodinium fucatum

Plate 17, Figs 11-12; Plate

Scriniodinium? sp. aff. S. obscurum .

Plate

Scriniodinium? sp

Plate

Spinidinium? sp. cf. S. clavus

Plate

Spinidinium echinoideum

Plate

Spiniferites $\mathrm{sp}$

Plate

Stiphrosphaeridium sp. aff. S. anthophorum .

Plate

Surculosphaeridium? longifurcatum

Plate

Tanyosphaeridium sp. cf. T. variecalamus

Plate

Trigonopyxidia ginella

Plate

Trithyrodinium suspectum

Plate 6, Figs 2-6; Plate

Wallodinium anglicum

Plate

Xenascus cf. aff. $X$. perforatus

Plate 5, Figs 9-12; Plate

17, Figs

6, Fig.

8-9

11, Figs

1

6, Figs

6, Figs

15, Figs

11, Fig.

4, Fig.

9, Fig.

13, Fig.

13, Fig.

8, Fig.

5, Figs

4, Fig.

17, Fig.

4, Figs

8, Fig.

6, Fig.

7, Figs

12, Fig.

9, Figs

12, Fig.

9, Fig.

11, Fig.

7-8

7-8

9-10

2-3

10

10

10

12

11

12

1-3

12

7

$2-6$

5

11

$1-2$

10

11-12

Acritarchs

Veryhachium cruciatum

. Plate

8, Figs $10-11$

Pollen

Aquilapollenites stelckii.

.. Plate

..Plate

Aquilapollenites sp.

Plate

Aquilapollenites clarireticulatus

.Plate

Pseudointegricorpus protrusum

Plate

Scollardia sp. cf. S. trapaformis

Plate

Wodehouseia sp. cf. W. fimbriata

Plate

Wodehouseia quadrispina.

Plate

Wodehouseia spinata

Plate

Wodehouseia stanley.

Plate

$\begin{array}{llr}18, & \text { Figs } & 1-4 \\ 18, & \text { Figs } & 7-8,10 \\ 18, & \text { Figs } & 5 \mathrm{a}-5 \mathrm{~b}, 9 \\ 18, & \text { Figs } & 6 \mathrm{a}-6 \mathrm{~b} \\ 18, & \text { Figs } & 11-12 \\ 19, & \text { Figs } & 11-12 \\ 19, & \text { Figs } & 9-10 \\ 19, & \text { Figs } & 7-8 \\ 19, & \text { Figs } & 1-3 \\ 19, & \text { Figs } & 4-6\end{array}$




\section{In pocket}

Enclosure 1. Svartenhuk composite

Enclosure 13. Central Nûgssuaq composite

Enclosure 33. Annertuneq

Enclosure 39. West Greenland composite 


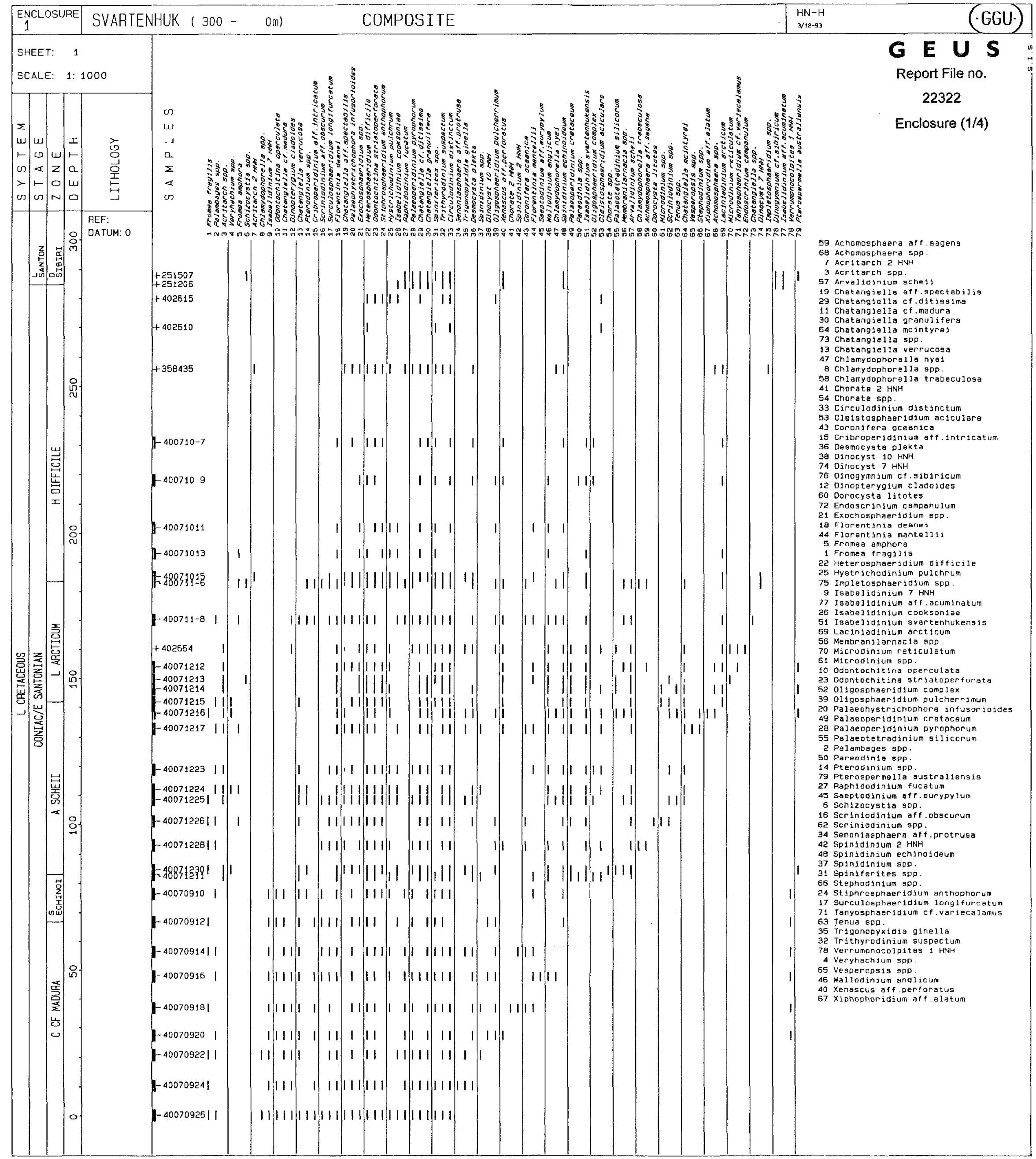


Bulletin Grønlands Geologiske Undersøgelse 170

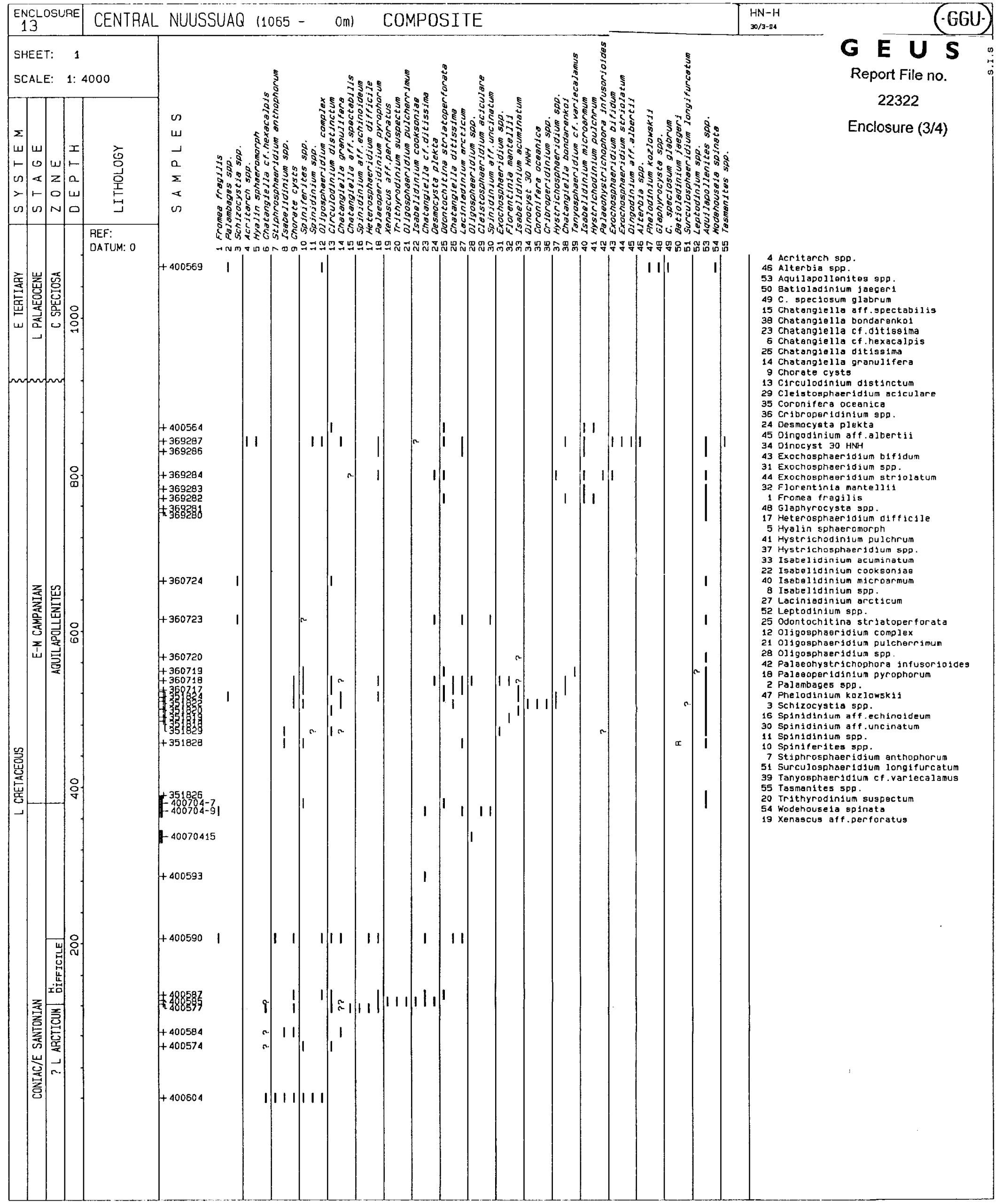




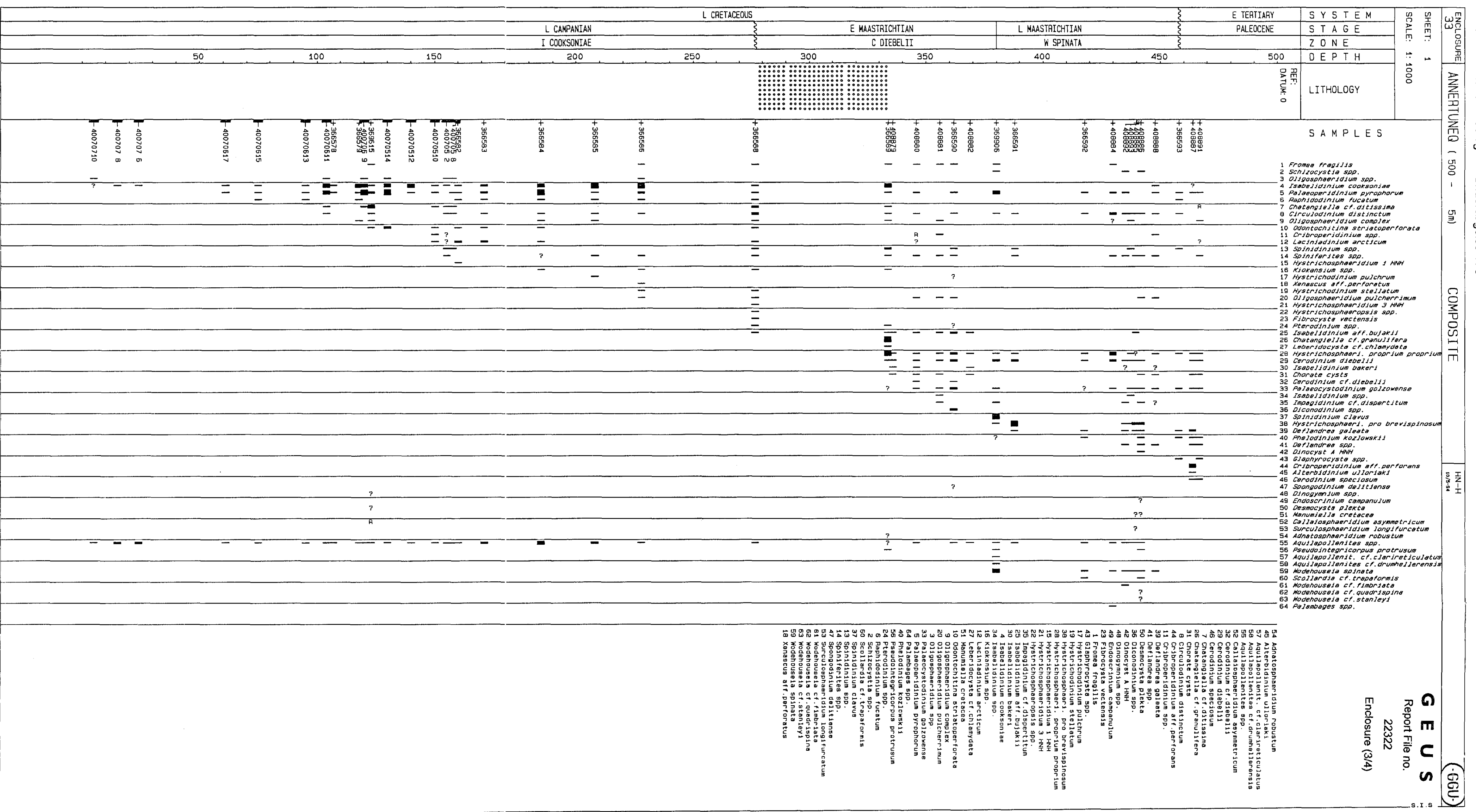




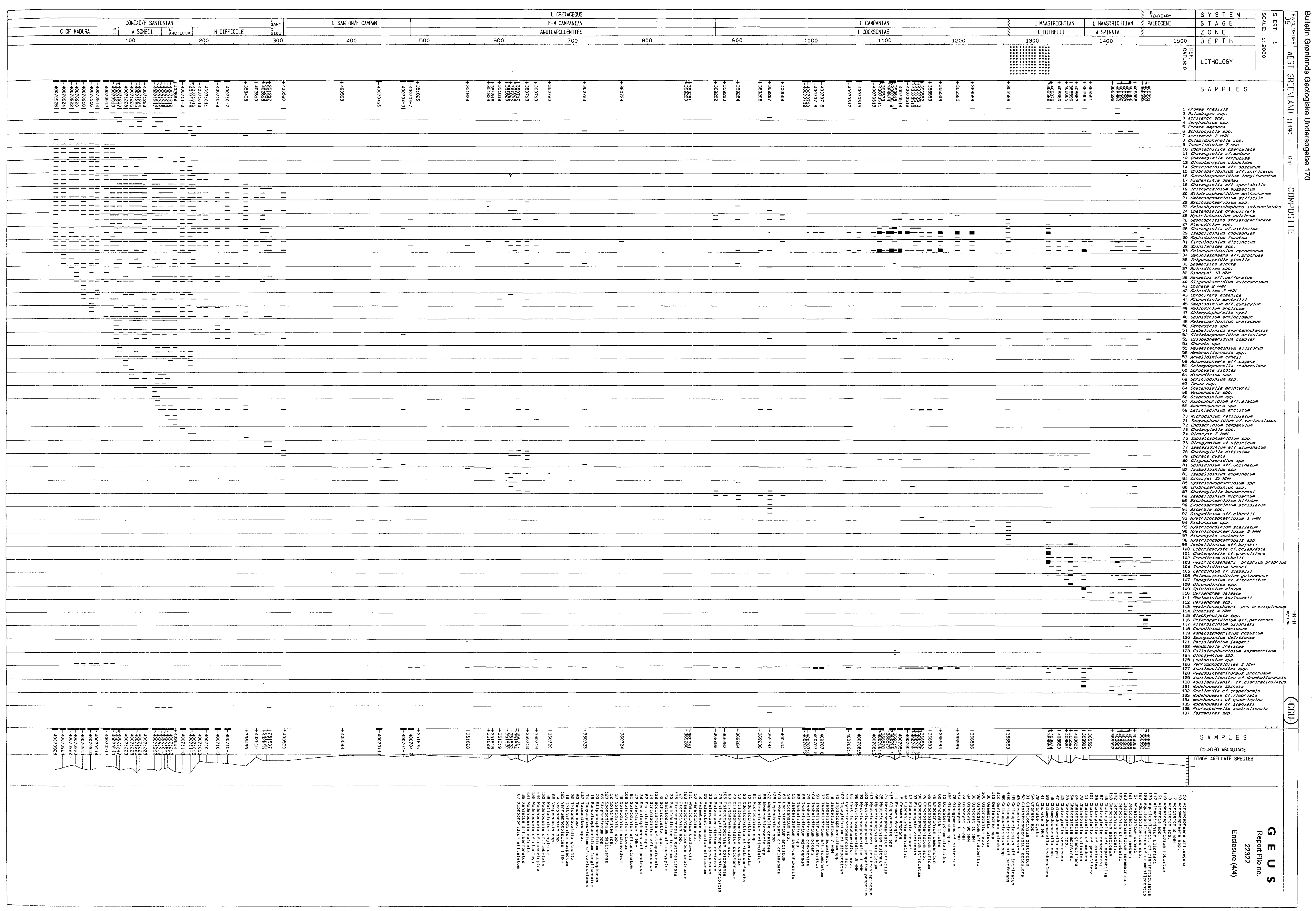

